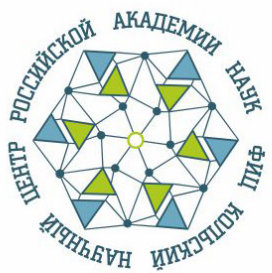

ИНСТИТУТ ЭКОНОМИЧЕСКИХ ПРОБЛЕМ ИМ. Г.П. ЛУЗИНА ФЕДЕРАЛЬНОГО ИССЛЕДОВАТЕЛЬСКОГО ЦЕНТРА

«КОЛЬСКИЙ НАУЧНЫЙ ЦЕНТР РОССИЙСКОЙ АКАДЕМИИ НАУК» 
МИНИСТЕРСТВО НАУКИ И ВЫСШЕГО ОБРАЗОВАНИЯ РОССИЙСКОЙ ФЕДЕРАЦИИ

ФЕДЕРАЛЬНЫЙ ИССЛЕДОВАТЕЛЬСКИЙ ЦЕНТР

«КОЛЬСКИЙ НАУЧНЫЙ ЦЕНТР РОССИЙСКОЙ АКАДЕМИИ НАУК»

ИНСТИТУТ ЭКОНОМИЧЕСКИХ ПРОБЛЕМ ИМ. Г. П. ЛУЗИНА

Р. В. Бадылевич, Е. А. Вербиненко

\section{ПОДХОДЫ К ПОСТРОЕНИЮ СИСТЕМЫ ФИНАНСОВОГО РЕГУЛИРОВАНИЯ \\ РАЗВИТИЯ РЕГИОНОВ СЕВЕРА \\ НА ОСНОВЕ ОЦЕНКИ \\ ФИНАНСОВОГО ПОТЕНЦИАЛА}

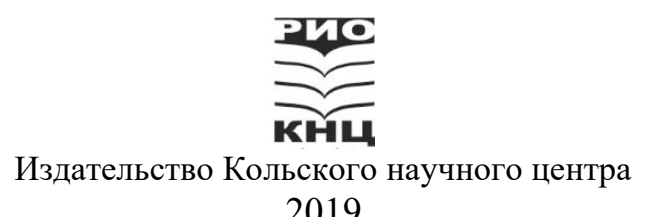




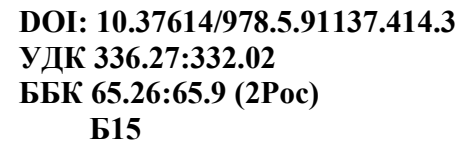

Авторы:

Бадылевич Роман Викторович - канд. экон. наук, старший научный сотрудник, ученый секретарь ИЭП ФИЦ КНЦ РАН;

Вербиненко Елена Александровна - канд. экон. наук, доцент, ведущий научный сотрудник ИЭП ФИЦ КНЦ РАН

\section{Рецензенты:}

Савельева С. Б. — д-р экон. наук, проф., зав. кафедрой экономики и управления морехозяйственной деятельностью ФГБОУ ВО «МГТУ»;

Острещов A. C. - канд. экон. наук, начальник отдела бухгалтерского учета главный бухгалтер департамента аграрной политики Воронежской обл.

\section{Бадылевич, Р. В.}

Подходы к построению системы финансового регулирования развития регионов Севера на основе оценки финансового потенциала : монография / Р. В. Бадылевич, Е. А. Вербиненко. - Апатиты : ФИЦ КНЦ РАН, 2019. — 144 с.: ил.

\section{ISBN 978-5-91137-414-3}

Представлены подходы к построению системы финансового регулирования развития регионов Крайнего Севера РФ. Рассмотрены элементы, объекты, инструменты и рычаги финансового регулирования, направленного на создание необходимых условий для увеличения финансового потенциала исследуемых субъектов РФ. Значительное внимание уделено анализу процессов формирования и оценке финансового потенциала региона, раскрывающего финансовые ресурсы субъектов экономики, факторы и условия их вовлечения, а также риски и угрозы, возникающие в процессе использования финансовых ресурсов.

Разъясняется сущность понятия «финансовый потенциал». Определены его основные элементы и аспекты управления. Рассмотрены существующие подходы к оценке финансового потенциала территориальных систем, и проведен сравнительный анализ различных методик по оценке финансового потенциала региона. По разработанной авторами методике определены значения составляющих финансовый потенциал элементов и совокупного финансового потенциала для регионов Крайнего Севера РФ. Сделан вывод о том, что оценка финансового потенциала региона может служить основой разработки сводных программ и стратегий развития северных территорий России и выступать как одна из характеристик, рассматриваемых при реализации тех или иных программ и проектов, выборе наиболее привлекательных с этой точки зрения регионов.

В монографии представлено обобщение проведенных в 2013-2018 гг. исследований авторов по вопросам оценки финансового потенциала и его значения для реализации финансового регулирования развития регионов. Работа рассчитана на широкий круг специалистов в области экономики и управления, студентов, аспирантов и преподавателей вузов.

Научное издание

Редактор С. А. Шарам

Технический редактор В. Ю. Жиганов

Подписано в печать 24.12.2019. Формат бумаги 70×108 1/16

Усл. печ. л. 12.6. Заказ № 31. Тираж 500 экз.

УДК 336.27: 332.02

ББК 65.26: 65.9 (2Poc)

\section{ISBN 978-5-91137-414-3}




\section{ОГЛАВЛЕНИЕ}

Введение.

Стр.

1. Теоретические основы и методологические подходы к содержанию территориального финансового регулирования на основе оценки финансового потенциала региона...............................

1.1. Финансовые ресурсы региона: содержание и структура......... 7

1.2. Методология реализации финансового регулирования территориального развития...............................

1.2.1. Сущность, содержание и инструменты финансового регулирования территориального развития

1.2.2. Особенности применения монетарных рычагов для регулирования региональных финансовых процессов 21

1.2.3. Особенности применения фискальных рычагов для регулирования региональных финансовых процессов 31

1.3. Содержание, оценка и управление финансовым потенциалом региона

2. Направления и инструменты реализации финансового регулирования северных территорий в России и за рубежом

$2 . .1$ Финансовое регулирование развития северных территорий в зарубежных странах

2.2. Государственное регулирование социально-экономического развития северных территорий в России: история и современность

3. Оценка и использование финансового потенциала для финансового регулирования развития северных регионов.

3.1. Оценка финансового потенциала северных регионов 88

3.2. Ранжирование и группировка регионов Крайнего Севера по интегральному показателю финансового потенциала

3.3. Инструменты формирования финансовых ресурсов для обеспечения устойчивого экономического регионов Севера: особенности и специфика применения

Заключение

Библиографический список 


\section{ВВЕДЕНИЕ}

В современных условиях проблема комплексного и сбалансированного развития остается актуальной для большинства регионов нашей страны. Сбалансированное территориальное развитие Российской Федерации предполагает обеспечение условий, позволяющих каждому региону иметь необходимые и достаточные ресурсы для комплексного развития и повышения конкурентоспособности экономики региона. Достижение этой цели зависит от того, как федеральные и региональные власти реагируют на изменения внешней и внутренней среды. Повышение эффективности управления региональными социально-экономическими процессами, совершенствование используемых финансовых методов (финансовых регуляторов) обеспечения устойчивости развития экономики региона становится одним из стратегических приоритетов развития РФ.

Используемые в России на протяжении последних десятилетий инструменты государственного финансового регулирования были направлены в первую очередь на повышение управляемости региональными процессами и централизацию финансовых потоков [1]. Такая политика привела к финансовой зависимости территорий от федерального центра, неспособности региональных органов власти в полной мере реализовывать финансовый потенциал субъектов РФ, утрате интереса к поиску форм и методов повышения финансовой привлекательности регионов. Сложившиеся финансовые механизмы в регионах ориентированы в основном на наполнение бюджета, в том числе за счет безвозмездных перечислений с вышестоящих уровней, при этом инструментам повышения ресурсной базы, формирования развитой финансовой инфраструктуры и достижения финансовой независимости региона уделяется недостаточное внимание. Следует отметить также существенную региональную асимметрию [2], которая выражается в неравномерной обеспеченности регионов финансовыми ресурсами.

Как известно, финансовые ресурсы являются одним из главных факторов обеспечения устойчивого развития экономики региона. В современных условиях их поиск во многом затруднен неблагоприятными макроэкономическими условиями, ограниченностью бюджетных средств, трудностями привлечения иностранных инвестиций. В связи с этим актуализировались проблемы совершенствования механизмов регионального управления и формирования принципиально новых инструментов реализации региональной политики, обеспечивающих наращивание собственного экономического потенциала территорий. Возрастает значение правильности принятия региональными органами власти решений, связанных с распределением ограниченных финансовых ресурсов, выбором наиболее действенных форм финансовой поддержки, использованием наиболее эффективных методов привлечения дополнительных финансовых ресурсов и с оптимизацией механизмов горизонтального и вертикального выравнивания.

Особенно важным решение данных задач представляется для регионов, которые характеризуются значительной удаленностью от федерального центра, наличием большого количества ресурсоемких отраслей, высокой степенью социальной незащищенности населения. Это северные и приравненные к северным субъекты РФ, неоднородные как по уровню социальноэкономического развития [3], так и по потенциалу формирования финансовых 
ресурсов. Финансовая самостоятельность и обеспеченность северных регионов, если учитывать их значительный вклад в экономическое развитие и доходы бюджетной системы страны, приобретает особую важность.

Первостепенной становится задача определения внутренних резервов развития регионов, решение которой связано с оценкой финансового потенциала региона. Финансовый потенциал включает в себя финансовые ресурсы, которыми регион располагает в настоящее время, и финансовые ресурсы, которые могут быть привлечены для обеспечения финансовой устойчивости региона. От его объема, структуры и качества зависят возможности социально-экономического развития, условия жизни населения.

Оценка финансового потенциала позволяет исследовать и оценивать состояние конкретного северного региона, проводить группировку регионов. Совокупная оценка финансового потенциала и его составляющих позволяет определять возможности рассматриваемых регионов привлекать финансовые ресурсы внутреннего происхождения. В условиях российской специфики спектр инструментов, используемых для привлечения финансовых ресурсов в регион, ограничен и каждый инструмент имеет свою специфику применения, исходя из показателей финансового потенциала.

В целом оценка финансового потенциала территории должна являться основой управления и перераспределения финансовых потоков между всеми участниками экономической системы региона: органами власти, хозяйствующими субъектами, финансово-кредитными институтами и домохозяйствами. Выявление наиболее перспективных элементов хозяйства региона с точки зрения возможности генерирования финансовых ресурсов, которые можно привлечь для обеспечения экономического роста субъекта РФ, должно способствовать созданию в регионе обоснованной системы финансовых инструментов развития и повышению эффективности использования рычагов финансирования инвестиционной деятельности.

В конечном итоге анализ количественных и качественных характеристик финансового потенциала отдельных субъектов РФ позволит сформировать дифференцированный подход к реализации региональной финансовой политики и разработке индивидуальных подходов к финансовому регулированию и их (субъектов) способности формировать необходимые финансовые ресурсы в различных секторах экономики.

В монографии представлено обобщение проведенных в 2013-2018 гг. исследований авторов по вопросам оценки финансового потенциала и его значения для реализации финансового регулирования развития регионов.

Глава 1 монографии базируется на результатах исследований авторов, отражающих теоретические основы и методологические подходы к содержанию финансового регулирования на основе оценки финансового потенциала и частично опубликованных авторами ранее ${ }^{1}$.

1 См.: Методологические подходы к содержанию и оценке финансового потенциала // Вестник ИНЖЭКОНа. Серия: Экономика. 2013. № 2 (61). С. 60-67; Финансовые рычаги регулирования территориального развития // Север и рынок: формирование экономического порядка. 2016. № 3 (50). С. 28-39; Финансовые рычаги как инструмент регулирования развития северных регионов // Север и Арктика в новой парадигме мирового развития. Лузинские чтения - 2016. 2016. С. 568-574; Финансовое обеспечение развития северных регионов / под науч. ред. Г. В. Кобылинской. Апатиты: КНЦ РАН, 2016. 193 с. 
Глава 2, посвященная финансовому регулированию развития северных территорий в России и зарубежных странах, основана на выводах, представленных и обоснованных в публикациях авторов ${ }^{2}$.

В основу 3 главы положены итоги исследований авторов в области оценки и использования финансового потенциала для регулирования развития северных регионов, частично опубликованные в научных трудах ${ }^{3}$ ранее.

При написании монографии использованы материалы отчетов о НИР, выполненной авторами в Институте экономических проблем им. Г. П. Лузина ФИЦ КНЦ РАН, в период 2013-2018 гг.

Кроме того, в издание включены еще не опубликованные материалы авторов по данной тематике, а также результаты новых проведенных исследований, касающихся истории и современного состояния государственного регулирования социально-экономического развития северных территорий Российской Федерации, оценки и использования финансового потенциала для финансового регулирования развития этих субъектов РФ.

2 См.: Инструменты, формы и методы финансового регулирования развития арктических территорий: зарубежный опыт // Север и рынок: формирование экономического порядка. 2017. № 2 (53). С. 104-115; Финансовое регулирование развития арктических территорий в зарубежных странах // Фундаментальные исследования. 2017. № 4-1. С. 126-132; Инструменты и методы финансового регулирования развития зарубежных арктических территорий // Север и Арктика в новой парадигме мирового развития. Лузинские чтения — 2018: материалы IX Междунар. науч.-практ. конф. / под общ. ред. Р. В. Бадылевича, Л. О. Залкинд. 2018. С. 115.

3 См.: Значение оценки финансового потенциала региона для финансового регулирования развития северных территорий // Управление экономическими системами: электрон. науч. журн. 2017. № 12 (106). С. 36; Дифференциация регионов Севера по уровню финансового потенциала // Интеллект. Инновации. Инвестиции. 2017. № 8. С. 7-13; Подходы к финансовому обеспечению сбалансированного развития экономики северных и приравненных к северным регионов РФ // Север и рынок: формирование экономического порядка. 2018. № 1 (57). С. 42-55; Финансовое регулирование развития регионов Крайнего Севера: институциональный аспект / коллектив авторов; под науч. ред. Г. В. Кобылинской. Апатиты: ФИЦ КНЦ РАН, 2018. 150 с. 


\section{1. ТЕОРЕТИЧЕСКИЕ ОСНОВЫ}

И МЕТОДОЛОГИЧЕСКИЕ ПОДХОДЫ К СОДЕРЖАНИЮ ТЕРРИТОРИАЛЬНОГО ФИНАНСОВОГО РЕГУЛИРОВАНИЯ НА ОСНОВЕ ОЦЕНКИ ФИНАНСОВОГО ПОТЕНЦИАЛА РЕГИОНА

\section{1. Финансовые ресурсы региона: содержание и структура}

В настоящее время особое значение приобретают вопросы финансовой самостоятельности и обеспеченности регионов. Решение этих вопросов в значительной степени зависит от структуры экономики и уровня ее развития на соответствующей территории. Все более актуальной становится проблема эффективной организации территориальных финансовых систем.

Территориальная система финансов представляет собой систему денежных отношений по формированию и использованию (расходованию) финансовых ресурсов региона для его экономического и социального развития.

Денежные отношения в регионе возникают: при взимании налогов и сборов с граждан и хозяйствующих субъектов; при получении финансовых ресурсов из федерального бюджета на развитие региона; при финансировании расходов на экономическую и социальную политику для жителей региона, расходов на выполнение спецзаказа региональных или местных органов власти с хозяйствующими субъектами; при возврате бюджетного кредита в федеральный бюджет и т. д.

Финансовую систему региона можно рассматривать с двух позиций.

С одной стороны, она - составная часть финансовой системы страны. Главной задачей территориальных финансов, в отличие от государственных, является концентрация финансовых ресурсов в распоряжении административнотерриториальных образований, находящихся на самоуправлении, и направление их на финансирование нужд региона и муниципальных образований.

Территориальные финансовые ресурсы формируются за счет налоговых и неналоговых доходов, безвозмездных поступлений и финансирования из вышестоящего бюджета.

С другой стороны, финансовую систему региона можно рассматривать как часть региональной социально-экономической системы, так как ей присущи все признаки социально-экономических систем:

- целенаправленность (является и управляющей, и управляемой);

- иерархичность (является системой, состоящей из подсистем, имеющих свои конкретные цели и функции);

- адаптивность (способность изменять параметрические характеристики в соответствии с изменяющимися внешними факторами).

Развитие финансовой системы региона происходит за счет воздействия как экстенсивных, так и интенсивных факторов.

К экстенсивным факторам можно отнести увеличение трансфертов из федерального бюджета, субсидий предприятиям, пенсий и пособий населению и др.

К интенсивным факторам развития региона можно отнести внедрение новой техники, технологий, использование инноваций, модернизацию производства, улучшение использования основных и оборотных фондов, 
повышение эффективности хозяйственной деятельности за счет лучшей ее организации. К интенсивным факторам относится также повышение качества систем управления и человеческого капитала региона.

Развитие финансовой системы региона подразумевает увеличение финансовых ресурсов, интенсивности финансовых потоков; оно происходит в результате еe глубокой структурной, функциональной и элементной перестройки, способствующей увеличению финансового потенциала региона.

Субъектами управления территориальными финансами выступают региональные органы власти: финансовый аппарат управления в лице законодательных органов, принимающих законы о финансах, и исполнительных органов субъектов Российской Федерации, направляющих, регулирующих, контролирующих финансовые процессы в государственном и негосударственном секторах экономики. Государственное управление финансами региона можно рассматривать как сознательное воздействие органов власти на финансовые отношения экономических субъектов территории и на их финансовые потоки, осуществляемое для достижения и поддержания сбалансированности, устойчивости экономики региона.

Объектом управления в системе являются финансовые ресурсы, представляющие собой денежные средства, формируемые в процессе создания и распределения валового регионального продукта, аккумулируемые регионом и субъектами хозяйствования и используемые в качестве источника поддержания и развития производства, удовлетворения социальных потребностей населения региональной системы.

Финансовые ресурсы предназначены для выполнения финансовых обязательств, покрытия затрат по расширенному воспроизводству, обеспечения социально-экономических процессов на определенной территории.

Согласно исследованию С. В. Стрельниковой [4, с. 10], финансовые ресурсы, созданные на территории, складываются из следующих важнейших частей:

- ресурсы бюджетов всех уровней - используются для текущего финансирования экономики региона, социальной сферы, финансирования наиболее важных проектов развития соответствующих территорий;

- ресурсы субъектов хозяйствования - используются для финансирования оборотных средств и капиталовложений, содержания социальных объектов, находящихся в собственности соответствующих субъектов хозяйствования;

- ресурсы внебюджетных фондов;

- кредитные ресурсы коммерческих банков и прочих финансовых структур - используются для срочного и возвратного финансирования оборотных средств и капиталовложений;

- дотации, субвенции и другие поступления из вышестоящих бюджетов для покрытия дефицита территориальных бюджетов и централизованные инвестиции - из федерального бюджета или федеральных инвестиционных фондов.

Таким образом, финансовые ресурсы региона определяются как финансовые ресурсы всех институциональных единиц, функционирующих в регионе (рис. 1).

Финансовые ресурсы не являются статичной категорией. Их формирование и использование тесным образом связано с процессами образования и перераспределения доходов всех участников финансовых отношений в регионе (населения, предпринимательских структур, органов власти и др.). 


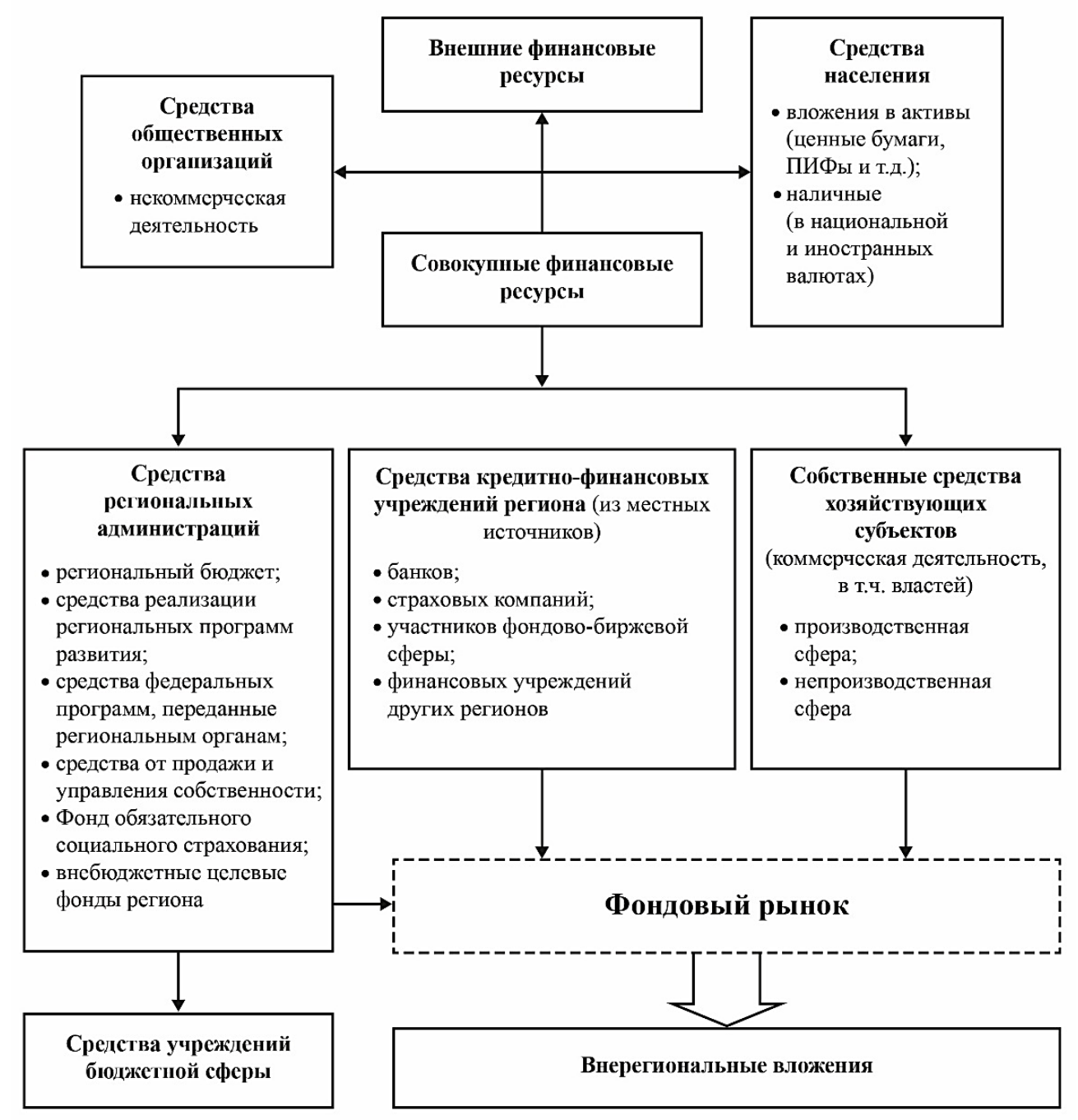

Рис. 1. Финансовая система региона (по принципу звеньев)

Финансовые ресурсы региона, согласно принятым в настоящий момент представлениям, могут быть разделены на три категории: созданные, образованные и располагаемые финансовые ресурсы. М. П. Пащенко раскрывает все три категории [5]. В первом случае - это финансовые ресурсы, которые были получены в результате производственно-хозяйственной деятельности хозяйствующих субъектов, функционирующих на территории региона. Во втором случае учитываются также денежные средства населения региона, в третьем - финансовые ресурсы представляют собой величину образованных финансовых ресурсов с учетом сальдо перераспределения ресурсов по фондам денежных средств. Это те ресурсы, которые могут быть использованы на территории региона для его производственного и социального развития.

Финансовые ресурсы выступают условием комплексного развития отдельных территорий и регионов. Достаточный уровень обеспеченности региональных систем финансовыми ресурсами является базой для эффективного 
функционирования кредитной системы, обеспечения реального сектора экономики инвестиционными ресурсами и формирования условий для реализации функций органов власти.

В связи с этим проблема обеспечения субъектов РФ необходимыми финансовыми ресурсами и их рациональной организации выходит на первый план при разработке стратегий сбалансированного развития территориальных систем.

Процесс управления финансовыми ресурсами тесно переплетен с организацией процесса движения финансовых потоков в регионе. Если финансовые ресурсы являются по своей сути моментной категорией, характеризующей состояние финансовой базы субъекта РФ на определенный момент времени, то финансовые потоки - динамическая категория, обусловливающая изменение количественных и качественных параметров региональных финансовых ресурсов за определенный временной промежуток. А значит, изменяя параметры входа, выхода и процесса при управлении финансовыми потоками, мы можем влиять и на состояние финансовых ресурсов. В качестве таких параметров будут выступать, прежде всего, параметры региональных налогово-бюджетной и инвестиционно-кредитной систем.

При построении системы организации финансовых ресурсов необходимо учитывать структуризацию региональных финансов в разрезе централизованных и децентрализованных элементов. К централизованным элементам региональных финансов следует отнести финансовые ресурсы органов власти субъектов РФ и муниципалитетов; в состав децентрализованных элементов будут входить финансовые ресурсы коммерческих и некоммерческих организаций, а также отдельных домохозяйств региона.

Централизованные финансовые ресурсы используются для решения задач, стоящих перед государственными органами власти, в соответствии с социально-экономическими приоритетами как общегосударственного характера, так и отдельных региональных систем.

Децентрализованные финансовые ресурсы дают возможность осуществлять экономические процессы в региональной хозяйственной системе.

Таким образом, несмотря на обеспечение реализации различных задач, централизованные и децентрализованные финансовые ресурсы взаимосвязаны и взаимозависимы.

При рассмотрении специфики организации централизованных и децентрализованных финансовых ресурсов следует отметить, что управление первой категорией осуществляется в законодательно установленном порядке (на основе принципов и показателей бюджетного устройства конкретных регионов и государства в целом), вторая же категория ресурсов базируется на принципах самостоятельности отдельных субъектов хозяйствования (при этом государство устанавливает общие правила формирования и использования и для децентрализованных финансовых ресурсов).

В целом следует отметить, что финансовые ресурсы являются сложной категорией, организация и управление которой требуют учета специфики как непосредственно параметров, характеризующих динамику и структуру финансовых ресурсов, так и сфер их формирования и использования.

Финансовые ресурсы являются одним из главных факторов обеспечения высоких темпов экономического роста региона. В современных условиях их поиск во многом затруднен неблагоприятными макроэкономическими 
условиями, ограниченностью бюджетных средств, трудностями привлечения иностранных инвестиций. Таким образом, на современном этапе повышается цена принятия неправильных решений в отношении формирования достаточного объема финансовых ресурсов для развития региона и поиска оптимальных источников их привлечения.

Низкую эффективность современной организации финансовых ресурсов в регионах РФ обусловливает то, что большинство субъектов РФ в настоящий момент является регионами-реципиентами, а значит, они испытывают острый недостаток финансовых ресурсов как для обеспечения текущих нужд, так и для финансирования устойчивого развития. При этом современные условия хозяйствования не способствуют росту финансовой самостоятельности регионов и наращиванию общего финансового потенциала. В этих условиях использование резервов повышения эффективности систем управления имеющимися финансовыми ресурсами представляется едва ли не единственным возможным направлением выхода на траекторию социально-экономического развития.

Современная организация региональных финансовых ресурсов должна базироваться на таких принципах:

- построение организации финансовых ресурсов на основе учета баланса федеральных, региональных и муниципальных интересов;

- сочетание рыночных и административных начал в системе организации региональных финансовых ресурсов;

- достоверный и регулярный расчет финансового потенциала как потребности региона в финансовых ресурсах;

- учет интересов всех участников регионального хозяйства (органов власти, коммерческого и некоммерческих секторов, домохозяйств) в процессе регламентации отношений в области формирования и использования финансовых ресурсов;

- использование инновационного зарубежного опыта организации региональных финансовых ресурсов.

Для сбалансированной организации финансовых ресурсов значение имеет и упорядочивание системы финансовых связей между субъектами региональных систем. В систему элементов, обеспечивающих рациональную организацию системы финансовых связей региона, согласно, например, выводам Г. Г. Фетисова и В. П. Орешина [6], необходимо включить следующие:

1. Установление материально-финансовой сбалансированности, которая достигается путем разработки двух взаимосвязанных документов - финансового баланса региона и регионального бюджета.

2. Мобилизация свободных финансовых ресурсов, которая позволяет решить проблему обеспечения развития и расширения производства за счет внутренних возможностей.

3. Контроль за соблюдением пропорции между денежными доходами населения и возможностями потребительского рынка.

4. Создание условий для нормального денежного оборота. Эта задача решается путем разработки кассового плана, призванного поддерживать зависимость между заработной платой и другими денежными выплатами населению и результатами деятельности торговли и сферы обслуживания. 
5. Обеспечение материально-финансовой сбалансированности инвестиционных процессов в регионе. Решение этой задачи во многом зависит от экономической структуры региона и возможностей развития материальнотехнической базы непроизводственной сферы.

Совокупность форм, методов и рычагов формирования и распределения финансовых ресурсов, используемых для обеспечения функционирования регионального хозяйства в режиме развития, представляет собой финансовый механизм региона.

Финансовый механизм - это внешняя оболочка финансов, проявляющаяся в финансовой практике воздействия на экономику и социальную сферу и в проведении единой финансовой политики регионов.

Финансовый механизм предполагает взаимосвязь следующих элементов (рис. 2):

- субъекты финансового механизма;

- объекты финансового механизма;

- обеспечение финансового механизма;

- средства воздействия финансового механизма на финансовую систему.

Определять основные задачи в регулировании экономических процессов и отношений в регионе и обеспечивать их реализацию, тем самым выступая в роли субъекта финансового механизма, призваны органы региональной администрации.

Задачей региональной администрации становится максимальная активизация эффективного использования всех финансовых ресурсов на основе учета особенностей отдельной региональной системы. Учитывая чисто региональную специфику сконцентрированных на территории ресурсов, выявив максимально возможный спектр интересов их собственников и возможности адаптации к рыночным условиям, региональные органы власти должны обеспечить сбалансированное вмешательство в воспроизводственный процесс по каждой группе финансовых ресурсов.

В качестве объектов финансового механизма выступают финансовые ресурсы региона. Совокупность всех финансовых ресурсов региона составляет его финансовый потенциал. Методология оценки финансового потенциала региона будет подробно рассмотрена далее.

Обеспечение финансового механизма региона включает в себя:

- правовое обеспечение - предусматривает определенное сочетание основных положений, отраженных в официальных документах (законах, постановлениях администрации региона, инструкциях, приказах и письмах департаментов и др.);

- нормативное обеспечение - состоит в применении норм, нормативов, тарифов, рекомендуемых методов и методик расчетов и т. д.;

- информационное обеспечение реализации финансового механизма предполагает использование таких принципов управления, как учет прошлого опыта, тенденций развития, влияние внешних и внутренних факторов на методы и инструменты управления и др.

Построение финансового механизма осуществляется в соответствии с экономической стратегией и финансовой политикой региона. Использование единых целей развития при построении механизма дает возможность установить 
единые правила организации финансовых связей, обеспечить эффективность движения финансовых потоков в регионе, защитить экономические интересы хозяйствующих субъектов.

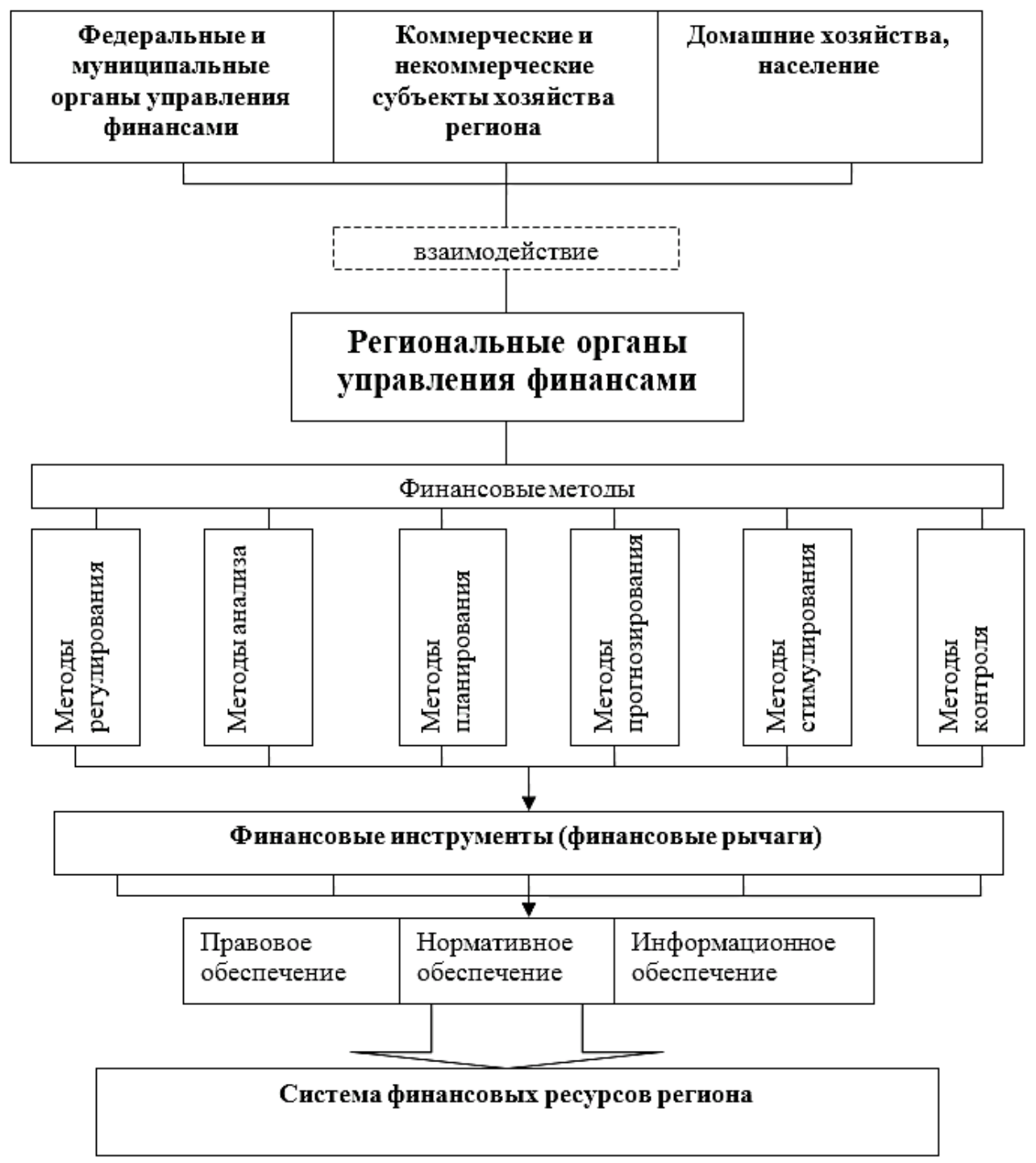

Рис. 2. Содержание финансового механизма региона

Построение финансового механизма региона предполагает четкое определение средств финансового механизма, в качестве которых выступают финансовые методы и инструменты, применяемые при формировании и использовании финансовых ресурсов на региональном уровне, а также при регулировании экономических процессов и отношений.

Методы финансового механизма можно определить как способ воздействия финансовых отношений на экономический процесс. Финансовые методы действуют в двух направлениях: по линии управления движением 
финансовых ресурсов и по линии рыночных отношений, связанных с соизмерением затрат и результатов, с материальным стимулированием и ответственностью за эффективное использование денежных фондов.

Реализация финансовых методов проявляется в использовании финансовых инструментов (финансовых рычагов).

\section{2. Методология реализации финансового регулирования территориального развития}

\subsection{1. Сущность, содерэсание и инструменты финансового регулирования территориального развития}

На современном этапе развития рыночной экономики в различных странах существует немало проблем, решение которых с помощью только рыночных инструментов невозможно. Поэтому государство активно вмешивается в экономические и социальные процессы, используя различные государственные рычаги воздействия.

Финансовое регулирование - это воздействие на экономические и социальные процессы путем концентрации финансовых ресурсов в отдельных структурах и уровнях социально-экономической системы и ограничение роста объема финансовых ресурсов в других.

Необходимость финансового регулирования обусловлена решением задач, связанных с удовлетворением потребностей всего общества - обеспечением крупных структурных сдвигов, поддержкой приоритетных направлений социально-экономического развития, расширением и совершенствованием объектов социальной сферы.

Государственное регулирование процессов в экономической сфере, в т. ч. и государственное финансовое регулирование, направлено на предотвращение возникающего дисбаланса, когда определенные отрасли экономики развиваются более быстрыми темпами и при этом возникает угроза перепроизводства. Общая направленность государственного регулирования экономики определяется главными целевыми установками всей экономической и финансовой политики.

В современной экономической литературе проблемы государственного регулирования рыночных процессов трактуются по-разному. Известные экономические школы кейнсианства, монетаризма, институциализма сформировали теории государственного регулирования, в которых формы и методы государственного регулирования экономических процессов имеют свои, отличные от других, формулировки.

Государство регулирует экономические процессы во всех экономических системах. В странах с рыночной экономикой такое регулирование осуществляется в меньшей степени, чем в административно-командной системе, но и в рыночной экономике роль государства велика.

Основными объектами государственного территориального регулирования выступают отраслевая структура экономики и ее территориальные пропорции.

В настоящее время во всех передовых и многих развивающихся странах налажено достаточно сильное государственное регулирование территориального развития, существующее в различных формах и видах: законодательное 
регламентирование; прогнозирование; планирование и программирование экономики; бюджетное перераспределение валового внутреннего продукта; государственные заказы; проведение целевой региональной политики налоговой, кредитно-финансовой и проч., контроль за ценами, доходами, занятостью, состоянием окружающей среды и т. Д. Для этого в центре и на местах создаются и функционируют специальные структуры исполнительной власти.

Зарубежная практика регионального развития свидетельствует о невозможности его успехов без сильной государственной поддержки, так как зачастую регионам требуются очень большие капиталовложения, не приносящие частному капиталу высокой прибыли. Конечно, многие насущные проблемы регионов (рассредоточение мегаполисов, экологическое оздоровление урбанизированных регионов, ликвидация хронической депрессивности территорий и др.) не удается полностью решить, но при отсутствии государственного регулирования они, несомненно, обострились бы до критического состояния [7].

Особенно актуальна необходимость финансового воздействия на территориальные пропорции (выравнивание уровня социально-экономического развития территорий) для стран, где в силу климатических условий, исторических традиций и неравномерности размещения природных ресурсов существуют заметные существенные диспропорции в экономическом и финансовом потенциалах отдельных регионов.

Основой регионального финансового регулирования за рубежом является бюджетное регулирование. Дифференцировать государства представляется возможным на основании степени децентрализации бюджетных систем. Степень такой дифференциации зависит главным образом от формы государственного устройства, которая подразумевает внутреннее строение страны и принципы взаимодействия ее составных частей (территорий). В настоящий момент выделяют простую форму государственного устройства (унитарное государство) и сложные формы (федерация, конфедерация). Безусловно, степень децентрализации региональных финансовых систем у стран со сложной формой государственного устройства будет гораздо выше по сравнению с унитарными государствами.

При этом отдельно в рамках каждого типа государственного устройства можно провести дополнительную градацию по степени централизации финансовых отношений. Так, например, среди унитарных стран можно выделить группу, которая не имеет отдельных структурных единиц, а на территории отсутствуют административные единицы. Как правило, это небольшие по территории государства (Мальта, Бахрейн, Сингапур). В этих странах необходимость осуществления регионального финансового регулирования отсутствует.

Достаточно многочисленна группа унитарных государств, которые характеризуются наличием лишь территориально-административных единиц и не имеют в своей структуре автономий (Польша, Словакия, Индонезия, Египет, Болгария и многие другие). В данной группе выделение отдельных административно-территориальных субъектов осуществляется в основном для управленческих функций. Финансовые полномочия территориальных органов власти ограничены, вся полнота финансовых рычагов управления 
сосредоточена на уровне государственных органов власти. Объемы и пропорции распределения финансовых ресурсов, выделяемых субъектам государства, определяются централизованно.

Среди унитарных государств следует выделить группу стран, имеющих одну или несколько автономий. Такие государства относят к сложным унитарных государствам (например, Испания, Великобритания, Дания, Франция, Китай). Как правило, финансовое регулирование в таких странах имеет ассиметричную форму, т. е. полномочия в области финансовых отношений основных территориальноадминистративных единиц и автономий могут заметно различаться (полномочия последних значительно шире).

В целом для унитарных государств характерна одно- или двухуровневая бюджетная система, при этом нижний уровень представлен бюджетами различных субъектов территориально-административного деления страны (так, в Японии, помимо государственного бюджета, формируются бюджеты префектур и муниципалитетов, во Франции - бюджеты департаментов и коммун, в Великобритании - бюджеты графств и округов). Основная часть финансовых потоков в унитарных государствах проходит через верхний уровень бюджетной системы - государственный бюджет, а государственные органы власти с помощью данного инструмента осуществляют перераспределение большей части национального дохода. Несмотря на то, что во многих унитарных странах провозглашены принципы автономии территориальных бюджетов, фактически степень их самостоятельности ограничена, а полнота финансовых полномочий сосредоточена на государственном уровне.

В федерациях, как правило, финансовые системы включают в себя три уровня: федеральный, региональный и местный, при этом каждое звено системы достаточно самостоятельно, обладает законодательно установленным объемом полномочий и функций. В мировой практике встречаются федеративные государства с разнообразными схемами распределения бюджетных полномочий и построения межбюджетных связей. Так, среди стран, где распространена практика ограничения финансовых прав субъектов федераций, можно выделить Канаду, Австралию. Примерами федераций с более широкими полномочиями субъектов являются США, Швейцария.

Спектр и специфика применения финансовых рычагов регулирования территориального развития в странах заметно различаются в силу исторических особенностей, сложившейся системы взаимоотношений «центр - территории», уровня финансовых возможностей государственных органов власти. Так, например, доля региональных и местных налогов в Канаде составляет более 50 \%, в США - около 35 \%, в Германии и Австралии - около $25 \%$. При этом для всех перечисленных стран общая доля региональных и местных доходов бюджетов после финансового выравнивания находится на уровне $45-58$ \%, т. е. в одних странах активнее используются налоговые инструменты регулирования территориального развития, в других - система финансовых перечислений в виде дотаций, субсидий, субвенций.

Вопросы реализации финансового регулирования регионального развития актуальны и для России, что подтверждает достаточно подробное освещение методологических и практических проблем реализации региональной финансовой политики в научных работах современных отечественных экономистов. 
Большинство авторов рассматривает финансовое регулирование развития территорий как процесс или действия, направленные на объект регулирования, в качестве которого выступает, как правило, региональная финансовая система. Можно привести определение Г. Н. Куцури, согласно которому регулирование региональной финансовой системы - это осуществляемый государственными органами комплексный процесс определения состава макропоказателей ее состояния, их целесообразных (эффективных) количественных характеристик, контроля за их достижением в ходе функционирования системы и разработки, внедрения прямых и косвенных мер стратегического, тактического и оперативного характера, которые направлены на обеспечение ее структурного и функционального развития с учетом общегосударственных нормативно-законодательных ограничений и задач с целью достижения максимального уровня социально-экономического развития региона [8].

Исследователи часто связывают процесс финансового регулирования развития территорий с выявлением и реализацией финансового потенциала регионов. Более подробно содержание финансового потенциала региона, его структура и механизм количественной оценки рассматриваются в подразделе 1.3.

Финансовое регулирование экономики происходит, во-первых, через стимулирование некоторых элементов экономической системы путем направления в них финансово-денежных ресурсов, во-вторых, через сдерживание других элементов путем ограничения объема поступающих в них финансово-денежных ресурсов. Для реализации этих целей используются различные формы и методы, которые и представляют инструментарий финансового регулирования экономики. При этом государство применяет как методы прямого, так и косвенного воздействия на экономику. Их различие, как известно, состоит в том, что методы прямого воздействия опираются на административный ресурс, тогда как косвенные методы регулирования реализуются только экономическими средствами. Это меры в области налогово-бюджетной, денежно-кредитной, валютной и таможенной политики, а также государственного регулирования предпринимательства и др.

Многие ведущие ученые-экономисты считают, что в рыночной экономике преобладают государственно-экономические, а не государственно-административные регуляторы.

Российская финансово-кредитная система обладает богатым набором финансовых и денежно-кредитных инструментов для финансового регулирования экономической сферы. Среди основных финансово-кредитных регуляторов, участвующих в процессе финансового регулирования экономической системы, можно выделить:

- налоговые и неналоговые платежи;

- финансовые санкции и льготы;

- доходы и расходы бюджетных организаций;

- финансовые трансферты и кредиты бюджетам разных уровней.

При этом каждому инструменту-регулятору соответствует свой набор методов финансового воздействия:

- налоговое регулирование (изменение перечня видов налогов, снижение налоговых ставок, предоставление налоговых льгот, введение определенного налогового минимума); 
- политика амортизационных отчислений (применение механизма ускоренной амортизации);

- государственная финансовая поддержка организаций, субъектов малого и среднего бизнеса, нижестоящих бюджетов - дотации, субсидии, субвенции, бюджетные кредиты, инвестиции; применение механизмов льготного страхования и кредитования.

Следует отметить, что финансовое регулирование осуществляется в таких формах, как использование собственных финансовых ресурсов (самофинансирование), привлечение денежно-кредитных ресурсов (кредитование), предоставление государственных финансовых ресурсов.

Все направления финансового регулирования экономики происходят в сферах денежно-кредитной (в рамках денежно-кредитного регулирования) и бюджетно-налоговой политики (в рамках бюджетного и налогового регулирования). Именно денежно-кредитная и бюджетно-налоговая политики являются наиболее мощным инструментом финансового регулирования социально-экономического развития страны в целом и регионов.

В современных исследованиях большое внимание уделяется инструментам и рычагам финансового регулирования территориальных пропорций, при этом различные авторы приводят собственную трактовку их содержания и классификации.

К примеру, Ф. Ф. Галлямов подразделяет инструменты и формы управления, регулирования и воздействия федерального центра на финансовую и экономическую систему субъекта РФ на директивные, административные, регулирующие, индикативные (согласительные, рекомендующие), преимущественно рыночные и косвенные [9].

При регулировании регионального развития федеральным центром Г. Н. Пономаренко выделяет две принципиально разные группы инструментов: инструменты выравнивания (межбюджетные трансферты, кредиты, частично ФЦП и т. д.) и инструменты стимулирования роста (особые экономические зоны, технопарки, потенциально возможное перераспределение налоговых доходов в пользу регионов и т. п.) [10].

В качестве групп методов государственного регулирования экономики регионов Е. Б. Дьякова выделяет прямые методы (бюджетное финансирование, государственный и местный заказ, государственные гарантии, госрегулирование цен, финансовая помощь регионам), косвенные методы (политика в области заработной платы, амортизационная политика, страховой механизм, денежный (эмиссионный) механизм) и смешанные методы (стимулирование развития через внебюджетные фонды, кредитная политика, налоговый механизм, лицензирование, госинвестиции) [11].

Многие авторы, признавая широкий комплекс инструментов воздействия на региональные финансы, указывают, что приоритетной и наиболее значимой группой являются бюджетно-налоговые инструменты. Так, В. П. Малахов [12] констатирует, что финансовое регулирование территориальных пропорций осуществляется преимущественно через механизм межбюджетного регулирования (регулирующие доходы; дотации, субсидии, субвенции бюджетам других уровней бюджетной системы), финансирование целевых программ поддержки и развития отдельных регионов и муниципальных образований. Аналогичную мысль высказывают Л. А. Велибекова и М. Г. Юсупова: государство воздействует 
на экономику различными финансовыми методами, но наиболее распространенными являются бюджетные, связанные с государственными расходами, и налоговые [13]. Одновременно региональные бюджеты признаются практически всеми исследователями основополагающим звеном, которое формирует региональные финансовые системы (см., например, [14, 15]).

Обобщая существующий спектр взглядов на систему реализации финансового регулирования территориального развития, можем сформировать общую систему финансовых рычагов регулирования финансовых процессов в субъектах РФ (рис. 3).

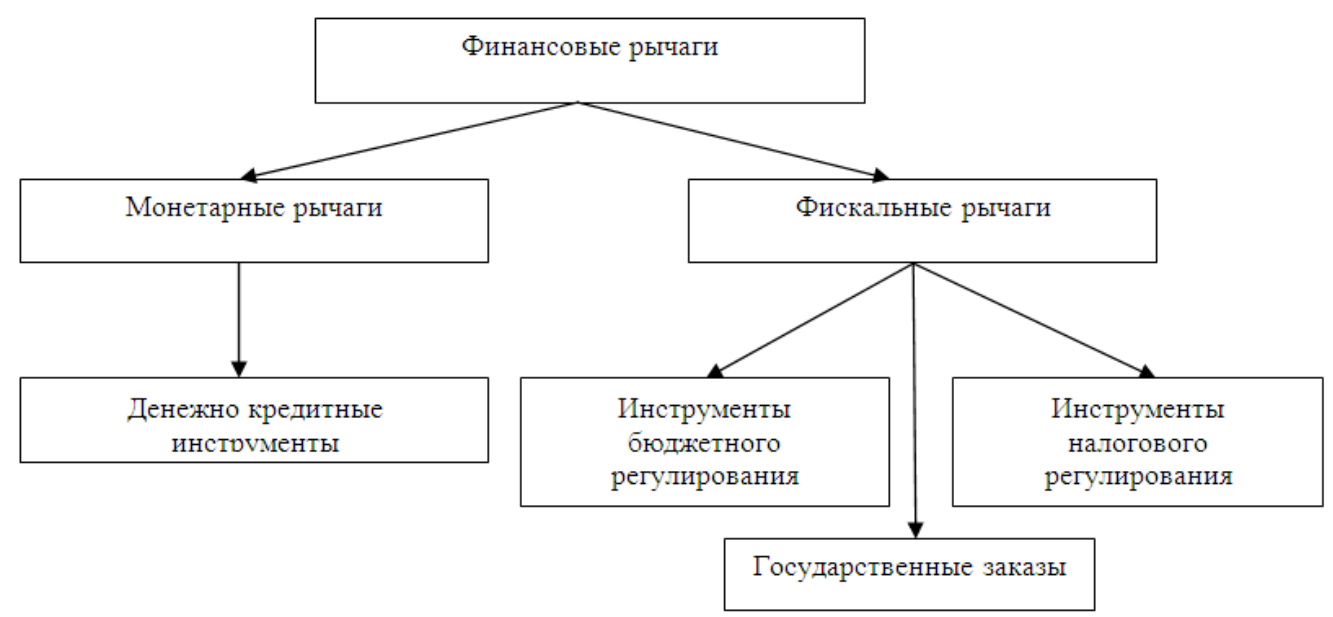

Рис. 3. Система финансовых рычагов

Возможность использования монетарных и фискальных рычагов для регулирования финансовых процессов существенно отличается относительно различных уровней управления (рис. 4).

В современных условиях возможности использования монетарных рычагов региональными органами власти в целом ограничены. В то же время фискальные рычаги являются действенным инструментом регулирования и перераспределения финансовых потоков в субъектах РФ.

Особенности использования каждой группы финансовых рычагов будут подробнее рассмотрены далее.

В настоящий момент спектр полномочий региональных органов в области принятия управленческих финансовых решений и использования финансовых рычагов в России достаточно ограничен. Это обусловлено низким уровнем финансовой самостоятельности органов власти субъектов РФ (см. подробнее: [16]).

С середины 2000-х гг. объем полномочий, возлагаемых на региональный уровень, неуклонно возрастает. Только за последние десять лет регионам было передано более 600 полномочий, причем многие из них не были финансово обеспечены. До настоящего момента по многим из них не определены источники финансирования: непонятно, должны ли выделяться средства на их реализацию из бюджетов субъектов РФ или же из федерального бюджета. Не способствует повышению региональной финансовой обеспеченности ограниченный потенциал 
формирования доходной базы. Перечень региональных налогов (налог на имущество организаций, транспортный налог, налог на игорный бизнес) в настоящий момент очень узок и диапазон принятия решений по ним на уровне субъекта РФ ограничен налоговым законодательством. Продолжается тенденция к концентрации в федеральном бюджете поступлений от наиболее значительных налогов, снижается потенциал получения налоговых доходов за счет использования схем изменения «прописки» крупных промышленных предприятий.

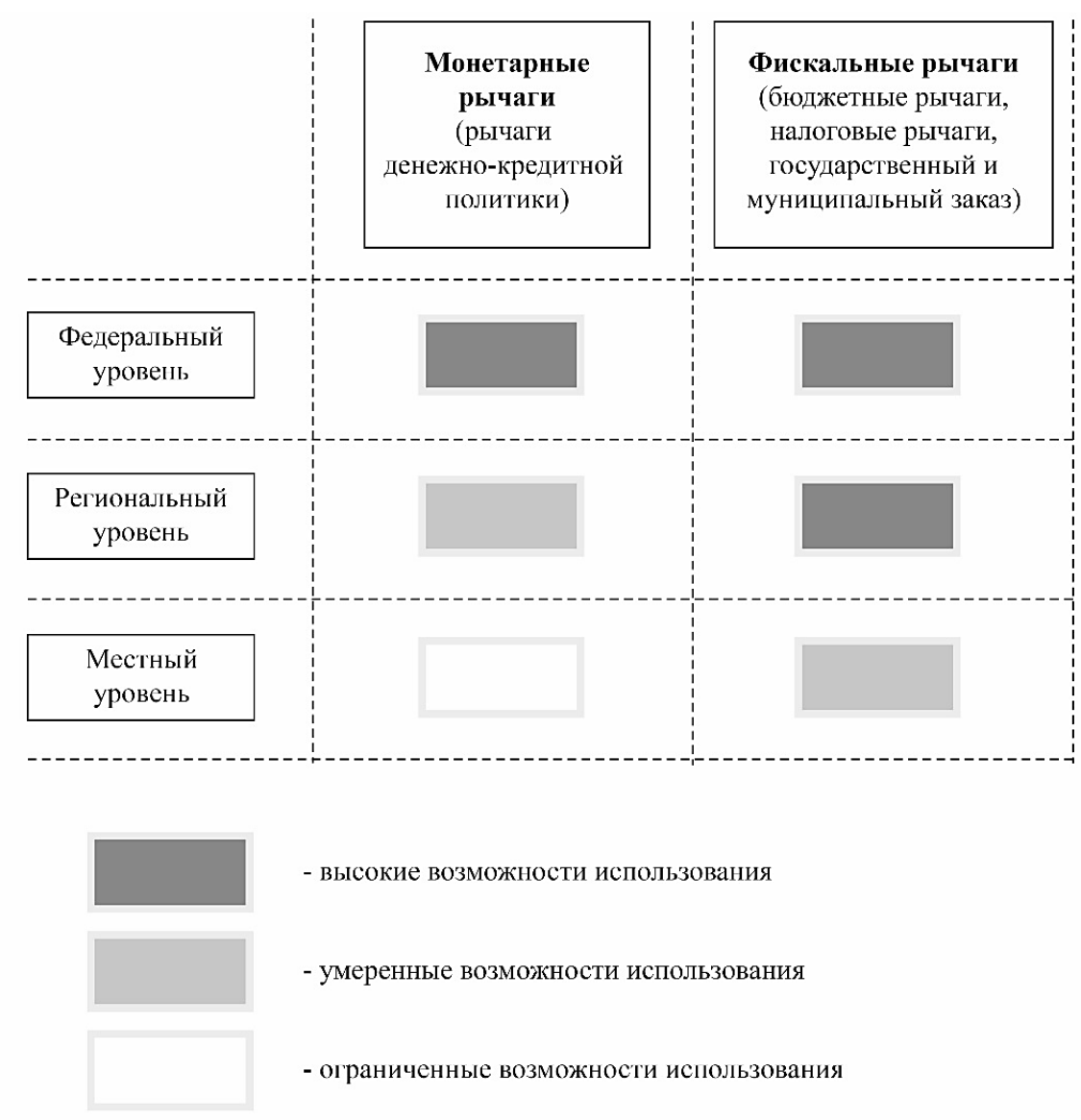

Рис. 4. Возможности использования финансовых рычагов на различных уровнях власти

Сохраняется высокая зависимость региональных бюджетов от бюджетных кредитов с вышестоящего уровня, межбюджетных трансфертов. Региональные бюджеты активно используют займы: общий объем государственного долга субъектов РФ на начало 2019 г. составил 2,2 трлн рублей [17]. При этом количество регионов-доноров сокращается (за последние пятнадцать лет количество регионов-доноров в России снизилось с 20 до 12 в 2018 г. $)^{4}$.

${ }^{4}$ В 2018 г. дотации на повышение бюджетной обеспеченности не получали следующие регионы: Республика Татарстан, Москва, Санкт-Петербург, Московская, Ленинградская, Самарская, Сахалинская, Свердловская и Тюменская области, Ненецкий, Ханты-Мансийский и Ямало-Ненецкий автономные округа. 
У региональных органов власти практически отсутствует возможность использовать нефискальные монетарные финансовые рычаги, что обусловлено спецификой реализуемой в России единой государственной денежно-кредитной политики Центрального банка РФ и отсутствием реальных полномочий в ее корректировке для различных регионов у территориальных учреждений Банка России.

В сравнении с зарубежной практикой в России остается низкой эффективность использования такого рычага регионального развития, как целевые программы. Это связано с ограниченностью средств, выделяемых на реализацию таких программ, с превалированием в структуре мероприятий целевых программ субъектов РФ для финансирования текущих задач в отличие от практики ведущих западных стран, где программные инструменты используются для достижения стратегических целей и формирования условий развития территорий.

\subsection{2. Особенности применения монетарных рычагов для регулирования региональных финансовых процессов}

Понятие денежно-кредитной политики, инструментами реализации которой выступают монетарные рычаги, является одним из базовых в системе финансового регулирования и управления. Денежно-кредитная система представляет собой часть общей государственной экономической политики, реализуемой монетарными органами управления посредством воздействия на экономические процессы через параметры денежно-кредитного рынка. Основной целью реализации денежно-кредитной политики в России является повышение благосостояния граждан страны. Несмотря на то, что спектр возможных целевых индикаторов реализации данной политики достаточно велик, в нашей стране основным приоритетом ее реализации является достижение стабильно низкого уровня инфляции вблизи 4 \% [18].

Основным субъектом, реализующим денежно-кредитную политику в Российской Федерации, является Центральный банк РФ. Банк России осуществляет свои функции в соответствии с Конституцией Российской Федерации, Федеральным законом «О Центральном банке Российской Федерации (Банке России)» [19] и иными федеральными законами. В соответствии со ст. 4 Федерального закона «О Центральном банке Российской Федерации (Банке России)», Банк России во взаимодействии с Правительством Российской Федерации разрабатывает и проводит единую государственную денежнокредитную политику.

Помимо Банка России в реализации денежно-кредитной политики участвуют финансовые органы власти, прежде всего Министерство финансов РФ, a также коммерческие банки, которые посредством различных каналов (процентного, кредитного, денежной массы и др.) доводят финансовые импульсы от использования денежно-кредитных инструментов ЦБ РФ до различных секторов экономики.

Важной задачей при определении специфики влияния монетарных рычагов на экономические процессы отдельных регионов является выявление содержания и особенностей применения данного вида финансовых инструментов. 
Непосредственно спектр монетарных рычагов, используемых при реализации денежно-кредитной политики, может быть представлен в соответствии со статьями 35-44 главы VII «Денежно-кредитная политика» Федерального закона «О Центральном банке Российской Федерации (Банке России)».

К таким инструментам отнесены:

- процентные ставки по операциям Банка России и рефинансирование кредитных организаций;

- обязательные резервные требования;

- операции на открытом рынке;

- валютные интервенции;

- установление ориентиров роста денежной массы;

- прямые количественные ограничения;

- эмиссия облигаций от своего имени;

- другие инструменты, определенные Банком России.

Значение каждого из приведенных денежно-кредитных рычагов и особенности применения приведены в табл. 1.

В конце XX в. денежно-кредитная политика Центрального Банка РФ была направлена на решение, прежде всего, тактических задач, тогда как стратегическим целям уделялось гораздо меньше внимания. Использование влияния низкого валютного курса на совокупный спрос и выпуск стимулировало развитие экспортно ориентированных отраслей. Рост ВВП отмечался при положительных значениях чистого экспорта, при этом негативное влияние испытывали другие отрасли, которое выражалось в низких уровнях инвестиций, отсутствии притока капитала. Одновременно падал и уровень жизни населения за счет снижения реальных доходов и потребления.

\section{Таблииа 1}

Содержание и особенности применения денежно-кредитных рычагов

\begin{tabular}{|c|c|c|}
\hline $\begin{array}{c}\text { Денежно-кредитный } \\
\text { рычаг }\end{array}$ & Содержание & Особенности применения \\
\hline $\begin{array}{l}\text { 1. Процентные ставки } \\
\text { по операциям Банка } \\
\text { России и } \\
\text { рефинансирование } \\
\text { кредитных } \\
\text { организаций }\end{array}$ & $\begin{array}{l}\text { Реализуется через } \\
\text { ключевую ставку } \\
\text { (ранее - ставка } \\
\text { рефинансирования, } \\
\text { в настоящий момент } \\
\text { имеет номинальный } \\
\text { характер) }\end{array}$ & $\begin{array}{l}\text { Ключевая ставка — ставка, } \\
\text { по которой Банк России } \\
\text { предоставляет кредиты } \\
\text { коммерческим банкам. Повышение } \\
\text { ставки ведет к подорожанию } \\
\text { валюты, снижению инфляции } \\
\text { и уменьшению инвестиционной } \\
\text { активности }\end{array}$ \\
\hline $\begin{array}{l}\text { 2. Обязательные } \\
\text { резервные } \\
\text { требования }\end{array}$ & $\begin{array}{l}\text { Реализуется через } \\
\text { установление норм } \\
\text { обязательного } \\
\text { резервирования } \\
\text { (беспроцентных } \\
\text { вкладов на счетах ЦБ } \\
\text { РФ) для коммерческих } \\
\text { банков }\end{array}$ & $\begin{array}{l}\text { Используется для контроля } \\
\text { кредитной активности } \\
\text { коммерческих банков, управления } \\
\text { ликвидностью в банковской сфере, } \\
\text { как инструмент страхования } \\
\text { депозитов }\end{array}$ \\
\hline
\end{tabular}


Окончание таблицьь 1

\begin{tabular}{|c|c|c|}
\hline $\begin{array}{c}\text { Денежно-кредитный } \\
\text { рычаг }\end{array}$ & Содержание & Особенности применения \\
\hline $\begin{array}{l}\text { 3. Операции } \\
\text { на открытом рынке }\end{array}$ & $\begin{array}{l}\text { Реализуется через } \\
\text { продажу-покупку } \\
\text { ценных бумаг ЦБ РФ, } \\
\text { операции РЕПО }\end{array}$ & $\begin{array}{l}\text { Регулируется количество денежных } \\
\text { средств в банковской системе, } \\
\text { кредитная активность } \\
\text { коммерческих банков }\end{array}$ \\
\hline $\begin{array}{l}\text { 4. Валютные } \\
\text { интервенции }\end{array}$ & $\begin{array}{l}\text { Реализуются через } \\
\text { покупку-продажу } \\
\text { ЦБ РФ иностранной } \\
\text { валюты на финансовых } \\
\text { рынках }\end{array}$ & $\begin{array}{l}\text { Регулируется курс национальной } \\
\text { валюты, совокупный спрос } \\
\text { и предложение денег, } \\
\text { волатильность валютного рынка }\end{array}$ \\
\hline $\begin{array}{l}\text { 5. Установление } \\
\text { ориентиров роста } \\
\text { денежной массы }\end{array}$ & $\begin{array}{l}\text { Реализуется } \\
\text { через установление } \\
\text { ориентиров роста, } \\
\text { прежде всего, для } \\
\text { денежного агрегата М2 }\end{array}$ & $\begin{array}{l}\text { Контролируется денежная масса } \\
\text { в РФ, обеспечивается соответствие } \\
\text { роста количества денег в экономике } \\
\text { темпу роста ВВП }\end{array}$ \\
\hline $\begin{array}{l}\text { 6. Прямые } \\
\text { количественные } \\
\text { ограничения }\end{array}$ & $\begin{array}{l}\text { Реализуются } \\
\text { через установление } \\
\text { обеспечения } \\
\text { под активные операции } \\
\text { банков, введение } \\
\text { лимитов по различным } \\
\text { операциям, ограничение } \\
\text { кредитной маржи, } \\
\text { установление } \\
\text { предельных кредитных } \\
\text { ставок }\end{array}$ & $\begin{array}{l}\text { Применяются в исключительных } \\
\text { случаях, направлены } \\
\text { на регулирование основных } \\
\text { процессов в области } \\
\text { функционирования финансового } \\
\text { рынка при возникновении } \\
\text { форс-мажорных обстоятельств }\end{array}$ \\
\hline $\begin{array}{l}\text { 7. Эмиссия облигаций } \\
\text { от своего имени }\end{array}$ & $\begin{array}{l}\text { Реализуется } \\
\text { через размещение } \\
\text { и обращение облигаций } \\
\text { ЦБ России среди } \\
\text { кредитных организаций } \\
\text { РФ }\end{array}$ & $\begin{array}{l}\text { Используется в целях } \\
\text { регулирования ликвидности } \\
\text { банковского сектора }\end{array}$ \\
\hline $\begin{array}{l}\text { 8. Другие } \\
\text { инструменты }\end{array}$ & $\begin{array}{l}\text { Депозитные операции с } \\
\text { коммерческими } \\
\text { банками (аукционы, } \\
\text { операции } \\
\text { по фиксированным } \\
\text { ставкам и т. д.), } \\
\text { количественные } \\
\text { и кредитные смягчения } \\
\text { и др. }\end{array}$ & $\begin{array}{l}\text { Используются для изъятия } \\
\text { излишней ликвидности } \\
\text { у коммерческих банков } \\
\text { или повышения кредитной } \\
\text { активности коммерческих банков }\end{array}$ \\
\hline
\end{tabular}

В связи с тем, что структура хозяйств отдельных регионов в России неоднородна, поддержка в 1990-е гг. в рамках применения денежно-кредитных рычагов сырьевых отраслей привела к существенному дисбалансу в показателях экономического роста отдельных субъектов РФ (в основном положительная динамика показателей отмечалась в регионах, имеющих сырьевой характер 
экономики). Избежать подобного перекоса можно было бы за счет эффективного и своевременного перераспределения денежных потоков от экспорта, однако данный механизм государственными органами власти так и не был создан.

В современных реалиях российской практики денежно-кредитная политика также рассматривается в основном как макроэкономический механизм воздействия на национальные финансовые процессы без учета специфики различий реакций на применение монетарных рычагов региональных финансовых систем. При этом существенная дифференциация уровней развития и структур региональных финансовых систем требует дополнительного внимания к оценке воздействия и прогнозирования влияния использования денежнокредитных инструментов на экономические процессы в отдельных субъектах РФ. Результаты такой оценки должны позволить определить возможность и целесообразность дифференцированного применения современных монетарных инструментов в отдельных регионах.

Излишняя централизация применения денежно-кредитных инструментов в современных условиях стала логичным итогом практики реализации денежнокредитной политики в нашей стране на протяжении последних трех десятилетий. Перекос монетарного регулирования в сторону обеспечения достижения стабильности национальной валюты, слабое внимание к формированию эффективного эмиссионного рынка, к структуре денежной массы и к обеспечению формирования сбалансированных кредитных и депозитных портфелей банковского сектора привело во многом к тому, что ключевые решения ЦБ РФ принимаются как реакция на изменение финансовой конъюнктуры и неблагоприятное изменение макроэкономических индикаторов, при этом основная задача денежно-кредитной политики - формирование условий для развития экономики и, как следствие, роста благосостояния граждан отходит на второй план.

Полноценная реализация денежно-кредитной политики невозможна без учета регионального фактора, который предполагает использование монетарного механизма для обеспечения социально-экономического развития отдельных регионов. Включение данной задачи в число приоритетных позволяет сформировать понятие и основное содержание региональной денежно-кредитной политики как элемента национального монетарного механизма.

Региональная денежно-кредитная политика - это деятельность государственных органов власти, направленная на регулирование и управление финансово-кредитной системой и денежно-кредитными потоками региона, основной задачей которой является обеспечение достаточных темпов экономического роста и стабильного развития финансового рынка субъекта РФ.

Центральный банк как основной субъект реализации денежно-кредитной политики на региональном уровне представлен отделениями главных управлений Центрального банка по федеральным округам в субъектах РФ. В настоящий момент территориальная структура Центрального банка РФ состоит из 7 главных управлений, которые отвечают за реализацию функций Банка России преимущественно в каждом из федеральных округов (исключение составляет Южное главное управление, осуществляющее работу в субъектах РФ Южного и Северо-Кавказского федеральных округов), а также 72 отделений главных управлений и 2 отделений непосредственно Центрального банка РФ (отделение по Республике Крым и отделение по городу Севастополю). 
Территориальные отделения осуществляют часть функций Центрального банка РФ в регионах и входят в единую централизованную систему. Их деятельность регламентируется Положением ЦБ РФ от 11.04.2016 № 538-П «О территориальных учреждениях Банка России» [20] (далее - Положение). Согласно данному документу в спектр задач территориальных отделений входит участие в проведении единой государственной денежно-кредитной политики, развитии и укреплении банковской системы Российской Федерации, организации наличного денежного обращения, обеспечении стабильности и развитии национальной платежной системы, а также развитии и обеспечении стабильности функционирования финансового рынка Российской Федерации в субъекте (субъектах) Российской Федерации.

Выделенные в этом же нормативном акте функции и анализ фактической деятельности территориальных учреждений Банка России позволяют представить возможности влияния территориальных структур ЦБ РФ на региональные финансово-кредитные процессы (рис. 5).

Анализ содержания выделенных в Положении функций позволяет говорить о том, что территориальные отделения ЦБ РФ номинально могут принимать участие в регулировании финансово-кредитных процессов в субъектах РФ за счет участия в проведении единой государственной денежно-кредитной политики и регулирования деятельности субъектов региональной финансовокредитной сферы. На практике же реализация первой из этих функций затруднена тем, что нормативно не закреплен механизм участия территориальных структур в регулировании финансово-кредитных процессов и отсутствует возможность дифференцированно (с учетом региональных особенностей и показателей развития отдельных субъектов РФ) использовать инструменты денежно-кредитной политики, вся полнота решений по которым сосредоточена на уровне Центрального аппарата Банка России.

В системе регулирования экономических процессов на субфедеральном уровне акцент значительно смещен в сторону использования фискальных рычагов (см. подробнее: [16]), при этом в научном сообществе возможности дифференцированного применения в региональном разрезе некоторых монетарных инструментов широко обсуждаются и обосновываются (например, [21-23]).

Возможность влияния на региональные финансово-кредитные процессы через вторую выделенную функцию (регулирование деятельности субъектов региональной финансово-кредитной сферы) у территориальных структур ЦБ РФ также в последние годы значительно снизилась, и связано это в первую очередь с тенденцией снижения количества региональных банковских организаций. Среди основных причин данной тенденции можно выделить: негативные тенденции на финансовом рынке последних лет; усиление контроля за деятельностью банков и противодействие нелегальным схемам работы в кредитном секторе экономики; расширение сферы влияния крупных банков федерального значения, в т. ч. за счет поглощения региональных банковских структур; общие тенденции к укрупнению бизнеса в сфере финансовых операций (см. подробнее: [24]). В связи с этим на практике роль территориальных отделений Банка России все больше сводится к обеспечению обслуживания платежной системы и выполнению функции информационного центра, который собирает определенную статистическую информацию и предоставляет ее в Центральный аппарат. 


\section{Сильное влияние на финансово-кредитные процессы в регионе}

\begin{tabular}{l} 
Участие в проведении \\
единой государственной \\
денежно-кредитной \\
политики \\
\hline
\end{tabular}

Функция на практике

территориальными отделениями

не реализуется
Регулирование деятельности кредитных

организаций, банковских групп, некредитных

финансовых организаций в регионах

(лицензирование, надзор и контроль)

(

Регистрация и контроль выпусков эмиссий, условий выпуска и обращения депозитных и сберегательных сертификатов.

Валютный контроль и контроль в области

противодействия легализации (отмыванию)

доходов, полученных преступным путем.

Участие в обеспечении стабильности и

развития национальной платежной системы,

реализации операционных функций.

Участие в организации наличного денежного обращения.

Участие в инспекционной деятельности.

Правовая деятельность.

Деятельность в области информатизации

Обеспечение комплексной безопасности.

Статистическая, аналитическая и

информационная деятельность. Участие

в международном сотрудничестве.
Функция на практике

территориальными отделениями реализуется

Слабое влияние на финансово-кредитные процессы в регионе

Рис. 5. Особенности реализации функций территориальных структур ЦБ РФ 
Согласно классическим представлениям, инвестиционная активность будет возрастать со снижением стоимости кредитных ресурсов для предприятий и, наоборот, снижаться с ростом стоимости кредитов. Привлекательность реализации инвестиционных проектов для хозяйствующих субъектов во многом определяется соотношением показателя стоимости привлекаемого капитала и потенциального уровня инвестиционной прибыли. Эти положения были подробно освещены в работах классиков экономической мысли Дж. Кейнса [25], М. Фридмана [26], А. Мелтцера [27] и др.

Среди располагаемых ЦБ РФ инструментов денежно-кредитной политики часть их них способна оказывать прямое влияние на средневзвешенную стоимость кредитных ресурсов для нефинансовых организаций. В частности, это процентные ставки по операциям Банка России, среди которых наиболее важную роль в настоящее время играет ключевая ставка (ранее, до 2014 г., - ставка рефинансирования). Ключевая ставка определяет коридор для установления процентных ставок по таким операциям Банка России, как кредиты «овернайт», сделки валютный СВОП, ломбардные кредиты, РЕПО, депозитные аукционы и операции. Как показывает практика последних лет, ЦБ РФ активно использует значение ключевой ставки для регулирования доступности дополнительных финансовых ресурсов для коммерческих банков в условиях колебаний финансовой конъюнктуры (так, ключевая ставка повышалась одномоментно на 6,5 \% в декабре 2014 г. [28] для снижения волатильности на финансовых рынках и уменьшения спекулятивного давления на национальную валюту).

Также на доступность кредитных ресурсов для субъектов реального сектора экономики влияет величина норм обязательных резервных требований. Обязательные резервы определяют размер остатков коммерческих банков на счетах Центрального банка и служат обеспечением выполнения банковских обязательств. Вместе с тем нормы обязательного резервирования рассматриваются и как механизм регулирования банковской ликвидности, влияющий на денежную массу и банковское предложение. Эффективность данного инструмента при реализации денежно-кредитной политики подтверждена как классиками экономической теории (М. Фридман [26], И. Фишер [29]), так и современными исследователями (например: [30, 31]). При повышении норм обязательного резервирования и снижении доступности рефинансирования кредитных организаций, в соответствии с классическим представлением, стоимость кредитных ресурсов возрастает.

Одновременно с выявлением влияния используемых инструментов денежно-кредитной политики Центрального Банка РФ на инвестиционную активность на национальном уровне возникает вопрос исследования взаимосвязи применения монетарных рычагов и уровня инвестиционной активности в отдельных регионах.

Исследованию данной взаимосвязи посвящена значительная часть диссертационного исследования Л. Л. Сперанской [32], в рамках которого на основе применения метода векторных авторегрессии (VAR) и статистических данных среди российских регионов выявлены три типа: группа регионов с отрицательной реакцией показателей инвестиционной активности (и, как следствие, индекса промышленного производства) на рост процентной ставки ЦБ 
РФ (закономерная динамика), группа с положительной реакцией на рост процентной ставки ЦБ РФ и третья группа - регионы, в которых наблюдается в отдельные периоды как положительная, так и отрицательная реакция (вторая и третья группа регионов могут быть отнесены к регионам с ассиметричной реакцией на финансовые шоки). В рамках своего исследования Л. Л. Сперанская также делает попытку объяснить отсутствие закономерной реакции достаточно многочисленной группы субъектов РФ на применение монетарных инструментов ЦБ РФ, указывая, что причинами этого являются непоследовательная работа трансмиссионных механизмов в данных регионах (по сути, неразвитость банковской системы) и более значительное влияние на инвестиционную активность таких факторов, как обеспеченность сырьевой базой и низкие значения реализации инвестиционной деятельности в прошедшие периоды.

Ряд исследователей проводил оценку влияния инструментов денежнокредитной политики на экономические процессы в конкретных субъектах Федерации (например, А. В. Резепин для Челябинской обл. [33], Л. А. Юдинцева для Республики Хакасия [34]), подтверждая вывод о неоднородности воздействия инструментов ЦБ РФ на экономическое развитие регионов.

Анализ взаимосвязи применения монетарных рычагов и реакций на финансовые шоки позволил авторам выделить факторы, влияющие на отклик региональных финансовых систем на использование инструментов денежнокредитной политики (рис. 6).

К таковым были отнесены:

- финансовый потенциал территории, соотношение номинального и используемого финансового потенциала;

- структура хозяйства региона и доля финансовых секторов в общем объеме валового регионального продукта;

- степень развития банковской сферы региона и ее структура в разрезе региональных и внешних банковских учреждений;

- инвестиционная привлекательность региона и наличие дефицита или избытка инвестиционных ресурсов.

Финансовый потенциал определяет возможности региона мобилизовать финансовые ресурсы для обеспечения достаточных темпов экономического развития (см. подробнее п. 1.3 и работу [35]). При этом номинальный финансовый потенциал характеризует максимально возможную финансовую базу, которая может быть привлечена для реализации инвестиционной деятельности и обеспечения экономических процессов за счет внутренних ресурсов региона. Используемый финансовый потенциал характеризует долю вовлеченного в экономические процессы номинального финансового потенциала на определенный момент времени и в определенных условиях. Закономерная реакция применения инструментов денежно-кредитной политики будет иметь место в субъектах с высоким финансовым потенциалом и значительной разницей между значениями номинального и используемого финансовых потенциалов (в противном случае общая ограниченность внутренних источников финансовых ресурсов даже в условиях проведения политики денежно-кредитной экспансии (политики «дешевых» денег») не позволит существенно увеличить предложение финансовых ресурсов). 


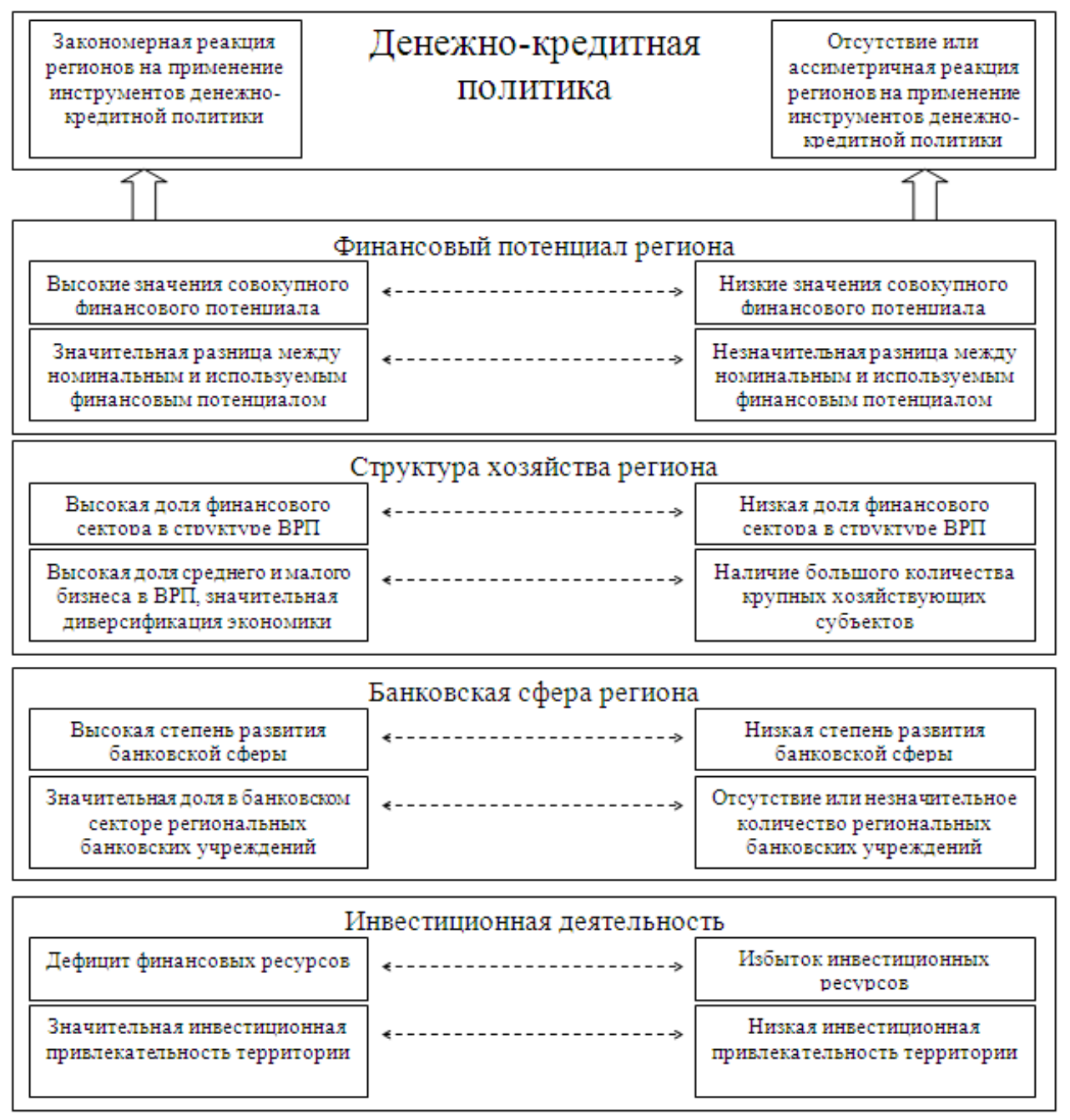

Рис. 6. Влияние факторов на восприимчивость региональных систем к использованию инструментов денежно-кредитной политики

Структура хозяйства региона, с одной стороны, определяет спрос на финансовые ресурсы экономическими субъектами, а с другой предопределяет степень развития трансмиссионных механизмов. В субъектах РФ, которые имеют системы хозяйства с промышленным укладом экономики, характеризующиеся высокой степенью специализации, основная доля производимого валового регионального продукта приходится на ограниченное количество предприятий. Как правило, такие крупные хозяйствующие субъекты в настоящее время входят в промышленно-финансовые группы и холдинги, что обусловливает широкие возможности для доступа к относительно дешевым финансовым ресурсам. Таким образом, изменение стоимости кредитных ресурсов в регионах с таким типом хозяйства в меньшей степени будет влиять на региональные экономические процессы, чем в регионах, где специализация экономики выражена слабее, а формирование регионального продукта в большей степени опирается на средний и малый бизнес. 
Степень развития трансмиссионных механизмов, позволяющих доводить эффекты от применения монетарных рычагов до конечных региональных экономических процессов, во многом определяется состоянием сформированной финансовой инфраструктуры (совокупность субъектов, опосредующих движение финансовых ресурсов в регионе), включающей в себя банковскую сферу, страховой рынок, рынок ценных бумаг, инвестиционные фонды и другие финансовые институты. Наиболее точно охарактеризовать степень развития финансовой инфраструктуры позволяет доля финансового сектора в формировании валового регионального продукта. В связи с этим логично утверждать, что в регионах, характеризующихся высокой долей финансового сектора в формировании ВРП, реакция на применение инструментов денежнокредитной политики будет более последовательной и ярко выраженной. По этой же причине предсказуемая реакция на применение монетарных рычагов должна наблюдаться в регионах, которые характеризуются более высокими показателями развития банковской сферы (к таковым следует отнести обеспеченность населения и организаций реального сектора экономики банковскими учреждениями, спектр предлагаемых банковских услуг и т. д.). При этом, выделяя банковскую сферу региона как отдельный фактор, определяющий реакцию региональных систем на использование инструментов денежно-кредитной политики, следует отметить важность ее структуры в разрезе региональных банковских учреждений, с одной стороны, и филиалов и подразделений столичных банков, с другой. В частности, степень предложения кредитных ресурсов со стороны региональных банковских структур в большей степени подвержена влиянию изменения норм обязательных резервных требований по сравнению с филиалами, кредитная активность которых во многом ограничена устанавливаемыми лимитами со стороны центрального аппарата. Таким образом, более высокая доля региональных институтов в структуре банковской сферы должна приводить к большей восприимчивости экономических систем региона при использовании монетарных инструментов.

Еще одним фактором, обусловливающим изменение спроса на финансовые ресурсы при использовании инструментов денежно-кредитной политики, является уровень развития инвестиционной деятельности в регионе. В регионах, в которых наблюдается избыток инвестиционных ресурсов (как правило, это регионы с низкой инвестиционной привлекательностью, ограниченным количеством потенциально эффективных крупных инвестиционных проектов, слабой инвестиционной активностью), реакция на «монетарные шоки» будет слабо выраженной или ассиметричной. Это объясняется ограниченностью дополнительной потребности в кредитных ресурсах даже при условии повышения их привлекательности по таким параметрам, как стоимость и доступность. При реализации политики денежно-кредитной экспансии в регионах, которые являются донорами с позиции баланса привлечения и размещения финансовых ресурсов внутри территории, высока вероятность того, что результат будет проявляться в увеличении разрыва между формируемой финансовой базой и объемом инвестиций при стабильном размере последних. В этом случае тенденция оттока финансовых ресурсов из региона будет превалировать над активизацией основных экономических процессов и, как следствие, значительной положительной динамики по основных региональным экономическим индикаторам ожидать не следует. 
Безусловно, степень влияния каждого из представленных факторов на практику применения монетарных рычагов неравномерна. В связи с этим поиск зависимостей между количественными характеристиками данных факторов и результирующими показателями, характеризующими общие экономические процессы в регионе, - важная задача, которая может быть решена с использованием экономико-статистического инструментария.

В настоящий момент перспективным направлением экономических исследований является построение эконометрических моделей, позволяющих выявить реакцию региональных систем на монетарные шоки - существенные изменения в действии отдельных денежно-кредитных рычагов. Данные модели могут быть основой принятия решений при оптимизации денежно-кредитной политики Центрального банка РФ в целях учета специфических реакций экономик субъектов РФ.

В моделях в качестве результирующих могут быть использованы показатели валового регионального продукта и индекса регионального промышленного производства.

В качестве факторных переменных в подобных моделях могут быть использованы такие показатели, как ключевая ставка Центрального банка РФ, реальный обменный курс национальной валюты, нормы резервных требований к коммерческим банкам, динамика денежного агрегата М2 и др.

\subsection{3. Особенности применения фискальных рычагов для регулирования региональных финансовых процессов}

Бюджетное регулирование территориального развития имеет специфические черты, отличающие его от других видов регулирования. Бюджетное регулирование территориального развития - это совокупность форм регулирования доходов, расходов территориальных бюджетов и межбюджетных отношений, являющихся частью финансового регулирования, осуществляемого финансово-экономическими методами прямого и косвенного действия в целях конкурентоспособного, устойчивого и безопасного развития территорий.

Целью бюджетного регулирования территориального развития является создание на определенной территории финансово-ресурсного базиса в результате формирования объема бюджетных ресурсов в достаточном количестве. Основными источниками бюджетных ресурсов выступают налоговые и неналоговые доходы. В качестве дополнительных доходных источников следует рассматривать трансферты и займы.

В систему рычагов, используемых для бюджетного регулирования на региональном уровне, следует включить такие отдельные элементы, как:

- единые и дополнительные нормативы отчислений от федеральных и региональных налогов и сборов, установленные органами государственной власти субъектов РФ;

- межбюджетные трансферты (дотации, субсидии, субвенции, прочие межбюджетные трансферты);

- прочие инструменты обеспечения бюджетной сбалансированности (бюджетные кредиты и ссуды). 
Одним из важнейших элементов государственного финансового регулирования, роль которого в современной экономической ситуации усилилась, являются межбюджетные отношения, в рамках которых происходит разграничение расходных обязательств и доходов, распределение доходов и перераспределение средств между региональными и местными бюджетами с целью финансового обеспечения расходных обязательств субъекта.

Совершенствование межбюджетных отношений на уровне субъекта Федерации и муниципальных образований, несмотря на внесенные в последнее время изменения в Бюджетный кодекс РФ, по-прежнему остается актуальным. Проблемы в сфере межбюджетных отношений - это не только и не столько проблемы взаимоотношений различных уровней власти, сколько проблемы организации рационального движения потоков финансовых ресурсов между бюджетами разных уровней в соответствии с установленным законодательством разграничением полномочий. В условиях ограниченности финансовых ресурсов усиливается необходимость их эффективного использования и, как следствие, возрастает необходимость в правильно построенной системе межбюджетных отношений.

В последние годы наблюдается заметный рост интереса к изучению содержания и подходов к оценке эффективности межбюджетных отношений внутри отдельных субъектов РФ, что обусловлено следующими причинами:

- усиление различий в социально-экономическом развитии отдельных регионов РФ;

- сохранение существенной асимметрии бюджетной обеспеченности отдельных муниципальных образований в границах отдельных регионов;

- усиливающаяся зависимость многих муниципальных образований от решений, принимаемых «региональным центром», и безвозмездных перечислений с регионального уровня;

- противоречивость и несистемность нормативно-правовой базы реализации межбюджетных отношений в отдельных субъектах РФ;

- формальный подход к реализации федеральных рекомендаций в области повышения эффективности межбюджетных отношений на региональном уровне во многих субъектах РФ.

Органы государственной власти задачу оптимизации межбюджетных отношений считали одной из приоритетных на протяжении всего современного этапа развития. Это подтверждает последовательное принятие и реализация документов, направленных на повышение эффективности взаимодействия между субъектами межбюджетных отношений в Российской Федерации.

К основным из них следует отнести:

- Концепцию реформирования межбюджетных отношений в Российской Федерации в 1999-2001 гг.;

- Программу развития бюджетного федерализма в Российской Федерации на период до 2005 г.;

- Концепцию реформирования бюджетного процесса в Российской Федерации в 2004-2006 гг.;

- Концепцию повышения эффективности межбюджетных отношений и качества управления государственными и муниципальными финансами в Российской Федерации на 2006-2008 гг.; 
- Концепцию межбюджетных отношений и организации бюджетного процесса в субъектах РФ и муниципальных образованиях до 2013 г. и план мероприятий по ее реализации;

- Программу повышения эффективности управления общественными (государственными и муниципальными) финансами на период до 2018 г.;

- Концепции повышения эффективности бюджетных расходов в 20192024 гг.

В настоящий момент в Российской Федерации понятие межбюджетных отношений закреплено в ст. 6 Бюджетного кодекса РФ [38]: «межбюджетные отношения - взаимоотношения между публично-правовыми образованиями по вопросам регулирования бюджетных правоотношений, организации и осуществления бюджетного процесса». Несмотря на то, что данное понятие определяет межбюджетные отношения в России в целом, оно может быть интерпретировано и для отдельных уровней бюджетной системы. Так, используя указанное определение для регионального уровня, достаточно ограничить спектр публично-правовых образований, участвующих в межбюджетных отношениях, региональными и местными органами власти, которые представляют определенный субъект РФ.

Межбюджетные отношения в бюджетной системе региона есть финансовые отношения между органом государственной власти субъекта РФ и органами местного самоуправления, возникающие при регулировании бюджетных правоотношений и осуществлении бюджетного процесса. Организация межбюджетных отношений имеет своей целью выравнивание бюджетной обеспеченности, стимулирование роста налогового потенциала, снижение рисков недофинансирования ключевых бюджетных услуг на местном уровне, финансовое регулирование развития экономики регионов.

В систему рычагов, используемых для реализации межбюджетных отношений на региональном уровне, следует включить такие отдельные элементы, как рычаги бюджетного регулирования, рычаги бюджетного планирования и рычаги бюджетного контроля (табл. 2).

В рамках каждой группы рычагов следует выделять отдельные финансовые рычаги, с помощью которых не только реализуются межбюджетные отношения, но и в целом осуществляется финансовое регулирование на уровне субъекта РФ.

Основным инструментом регулирования, через который происходит реализация межбюджетных отношений в России, являются межбюджетные трансферты. В России применяется три основные формы межбюджетных трансфертов нижестоящим бюджетам. Они перечислены в ст. 129 Бюджетного кодекса РФ. Это дотации на выравнивание бюджетной обеспеченности, субсидии, субвенции. Кроме того, Бюджетный кодекс предусматривает иные формы межбюджетных трансфертов, которые, впрочем, подробно не расшифровывает.

В качестве отдельной формы межбюджетных трансфертов ст. 129 Бюджетного кодекса РФ также упоминает межбюджетные трансферты бюджетам государственных внебюджетных фондов. Тем самым внебюджетные фонды могут рассматриваться как самостоятельные участники межбюджетных отношений на региональном уровне. 
Рычаги межбюджетных отношений на региональном уровне

\begin{tabular}{|c|c|}
\hline $\begin{array}{c}\text { Группы } \\
\text { бюджетных рычагов }\end{array}$ & Финансовые рычаги \\
\hline \multirow{2}{*}{$\begin{array}{l}\text { 1. Рычаги } \\
\text { бюджетного } \\
\text { планирования }\end{array}$} & $\begin{array}{l}\text { Утверждение бюджетов субъектов РФ } \\
\text { и муниципальных образований } \\
\text { на очередной финансовый год и плановый период }\end{array}$ \\
\hline & $\begin{array}{l}\text { Наличие утвержденного перечня приоритетных } \\
\text { расходных обязательств муниципальных образований, } \\
\text { в целях софинансирования которых предоставляются } \\
\text { субсидии из бюджета субъекта РФ }\end{array}$ \\
\hline \multirow[b]{2}{*}{$\begin{array}{l}\text { 2. Рычаги } \\
\text { бюджетного } \\
\text { контроля }\end{array}$} & $\begin{array}{l}\text { Мониторинг соблюдения } \\
\text { муниципальными образованиями } \\
\text { требований бюджетного законодательства РФ }\end{array}$ \\
\hline & $\begin{array}{l}\text { Контроль за соблюдением органами местного } \\
\text { самоуправления нормативов формирования расходов } \\
\text { на оплату труда депутатов, выборных должностных лиц } \\
\text { местного самоуправления и содержание органов } \\
\text { местного самоуправления }\end{array}$ \\
\hline \multirow{3}{*}{$\begin{array}{l}\text { 3. Рычаги } \\
\text { бюджетного } \\
\text { регулирования }\end{array}$} & $\begin{array}{l}\text { Единые и дополнительные нормативы отчислений } \\
\text { от федеральных и региональных налогов и сборов, } \\
\text { установленные органами государственной власти } \\
\text { субъектов РФ }\end{array}$ \\
\hline & $\begin{array}{l}\text { Межбюджетные трансферты (дотации, субсидии, } \\
\text { субвенции, прочие межбюджетные трансферты) }\end{array}$ \\
\hline & $\begin{array}{l}\text { Прочие инструменты обеспечения бюджетной } \\
\text { сбалансированности (бюджетные кредиты и ссуды) }\end{array}$ \\
\hline
\end{tabular}

В настоящий момент один из основных вопросов в системе изучения межбюджетных отношений на региональном уровне - это разработка методики определения их эффективности. Единой законодательно закрепленной методики расчета показателей, характеризующих степень эффективности межбюджетных взаимоотношений в субъекте РФ, на сегодняшний день нет. При этом следует отметить, что законодательные органы власти обращают свое внимание на данный спектр вопросов, следствием чего является разработка и принятие нормативных актов, задачей которых является систематизация подходов к оценке межбюджетных отношений внутри регионов.

Так, следует выделить приказ Минфина России «О Порядке осуществления мониторинга и оценки качества управления региональными финансами» [37], в котором содержится методика расчета и интерпретация показателей, характеризующих отдельные направления финансовых отношений в субъектах РФ. Все индикаторы, содержащиеся в документе, разделены на две группы: индикаторы качества управления региональными финансами в субъектах Российской Федерации и индикаторы соблюдения бюджетного законодательства при осуществлении бюджетного процесса. В рамках первой группы дополнительно выделено 8 направлений, включающих в себя в общей сложности 54 индикатора. 
Непосредственно на оценку межбюджетных отношений в регионе направлены индикаторы четвертой группы, которые в методике обозначены как «финансовые взаимоотношения с муниципальными образованиями». По данному направлению для каждого субъекта РФ определяется 8 индикаторов, (табл. 3).

Практическое использование данной методики для оценки межбюджетных отношений в регионе было представлено авторами в работе «Методологические и практические аспекты оценки межбюджетных отношений на региональном уровне (на примере Мурманской области)» [38].

Таблица 3

Характеристика индикаторов

по направлению «финансовые взаимоотношения с муниципальными образованиями» в соответствии Порядком осуществления мониторинга и оценки качества управления региональными финансами

\begin{tabular}{|c|c|c|}
\hline Индикатор & $\begin{array}{c}\text { Степень важности } \\
\text { (удельный вес } \\
\text { в совокупной } \\
\text { оценке) }\end{array}$ & $\begin{array}{c}\text { Трактовка } \\
\text { результата } \\
\text { (целевое значение) }\end{array}$ \\
\hline $\begin{array}{l}\text { U41. Проведение мониторинга соблюдения } \\
\text { муниципальными образованиями требований } \\
\text { бюджетного законодательства РФ и оценки } \\
\text { качества управления бюджетным процессом } \\
\text { в муниципальных образованиях субъекта } \\
\text { Российской Федерации }\end{array}$ & 1,0 & $\begin{array}{l}\text { Да/нет } \\
\text { (положительное } \\
\text { значение «да») }\end{array}$ \\
\hline $\begin{array}{l}\text { U42. Соотношение объема дотаций } \\
\text { на выравнивание бюджетной обеспеченности } \\
\text { муниципальных образований и объема } \\
\text { субсидий муниципальным образованиям } \\
\text { из регионального бюджета }\end{array}$ & 1,5 & $\begin{array}{l}\text { Увеличение } \\
\text { значения } \\
\text { свидетельствует } \\
\text { о повышении } \\
\text { качества } \\
\text { управления }\end{array}$ \\
\hline $\begin{array}{l}\text { U43. Соотношение налоговых доходов } \\
\text { местных бюджетов, поступивших по единым } \\
\text { и дополнительным нормативам отчислений } \\
\text { от федеральных и региональных налогов } \\
\text { и сборов, установленных органами } \\
\text { государственной власти субъектов } \\
\text { Российской Федерации, и налоговых доходов } \\
\text { местных бюджетов, поступивших в } \\
\text { соответствии с пунктами } 1 \text { и } 2 \text { статей } 61,61.1 \text {, } \\
61.2, \text { пунктом } 3 \text { статьи } 58 \text { Бюджетного } \\
\text { кодекса Российской Федерации }\end{array}$ & 1,5 & То же \\
\hline $\begin{array}{l}\text { U44. Эффективность выравнивания } \\
\text { бюджетной обеспеченности муниципальных } \\
\text { образований }\end{array}$ & 1,5 & $\begin{array}{l}\text { Снижение } \\
\text { значения } \\
\text { свидетельствует } \\
\text { о повышении } \\
\text { качества } \\
\text { управления }\end{array}$ \\
\hline
\end{tabular}


Окончание таблицьы 3

\begin{tabular}{|c|c|c|}
\hline Индикатор & $\begin{array}{c}\text { Степень } \\
\text { важности } \\
\text { (удельный вес } \\
\text { в совокупной } \\
\text { оценке) }\end{array}$ & $\begin{array}{c}\text { Трактовка } \\
\text { результата } \\
\text { (целевое значение) }\end{array}$ \\
\hline $\begin{array}{l}\text { U45. Проведение контроля за соблюдением } \\
\text { органами местного самоуправления } \\
\text { нормативов формирования расходов } \\
\text { на оплату труда депутатов, выборных } \\
\text { должностных лиц местного самоуправления, } \\
\text { осуществляющих свои полномочия } \\
\text { на постоянной основе, муниципальных } \\
\text { служащих и (или) содержание органов } \\
\text { местного самоуправления, в соовветствии } \\
\text { с нормативным правовым актом субъекта } \\
\text { Российской Федерации }\end{array}$ & 1,0 & $\begin{array}{l}\text { Да/нет } \\
\text { (положительное } \\
\text { значение «да») }\end{array}$ \\
\hline $\begin{array}{l}\text { U46. Утверждение бюджетов } \\
\text { муниципальных образований на очередной } \\
\text { финансовый год и плановый период }\end{array}$ & 0,75 & $\begin{array}{l}\text { Увеличение } \\
\text { значения } \\
\text { свидетельствует } \\
\text { о повышении } \\
\text { качества } \\
\text { управления }\end{array}$ \\
\hline $\begin{array}{l}\text { U47. Доля целевых межбюджетных } \\
\text { трансфертов, предоставляемых местным } \\
\text { бюджетам из бюджета субъекта Федерации } \\
\text { в очередном финансовом году, } \\
\text { распределяемых законом о бюджете субъекта } \\
\text { Российской Федерации, в общем объеме } \\
\text { целевых межбюджетных трансфертов, } \\
\text { предоставляемых местным бюджетам } \\
\text { из бюджета субъекта Российской Федерации }\end{array}$ & 2,0 & То же \\
\hline $\begin{array}{l}\text { U48. Наличие утвержденного на срок } \\
\text { не менее } 3 \text { лет перечня расходных } \\
\text { обязательств муниципальных образований, } \\
\text { в целях софинансирования которых } \\
\text { предоставляются субсидии из бюджета } \\
\text { субъекта Российской Федерации, } \\
\text { с установленными целевыми показателями } \\
\text { результативности предоставления субсидий } \\
\text { и их значениями }\end{array}$ & 0,75 & $\begin{array}{l}\text { Да/нет } \\
\text { (положительное } \\
\text { значение «да») }\end{array}$ \\
\hline
\end{tabular}

Государственное налоговое регулирование является элементом фискального регулирования и представляет собой систему специальных приемов, методов и инструментов управления налогообложением и налоговыми потоками, направленную на целенаправленное вмешательство государства в экономику в соответствии с принятой им концепцией экономического роста. Целью 
налогового регулирования является создание условий для роста налоговых поступлений в бюджетную систему путем воздействия на различные стороны хозяйственной жизни и экономику в целом [39].

Одним из важнейших способов налогового регулирования экономики субъектов РФ является установление закрепленных и регулирующих налогов. В настоящее время Бюджетный кодекс РФ определяет порядок формирования налоговых доходов бюджетов всех уровней, что позволяет субъектам РФ заранее планировать бюджеты.

Впервые деление налогов на федеральные, региональные и местные налоги было предусмотрено в Законе РФ от 27.12.1991 № 2118-1 «Об основах налоговой системы в Российской Федерации» [40]. В нем широко использовался механизм закрепленных и регулирующих налогов. В части региональных налогов субъекты РФ могли устанавливать налоговые ставки и налоговые льготы.

Развитие системы инструментов налогового регулирования экономики субъектов РФ с начала 1990-х гг. можно охарактеризовать следующими тенденциями:

- сокращение числа налогов субъектов РФ;

- сужение полномочий субъектов РФ в сфере налоговых инструментов регулирования региональной экономики; кодексе РФ.

- четкое закрепление перечня регулирующих налогов в Бюджетном

Необходимо отметить, что существует такая зависимость: более высокий уровень экономического развития и налоговых доходов бюджета региона обусловливает наличие больших возможностей регулировать экономику с помощью налоговых методов. Низкий уровень развития экономики предполагает слабую реакцию экономики на налоговые методы. Поэтому значение налоговых инструментов регулирования экономики выше в тех субъектах РФ, где выше уровень экономического развития.

Налоговые методы регулирования соотносятся с отдельными элементами налогообложения. К таковым следует отнести (ст. 17 НК РФ [41]): объект налогообложения, налоговую базу, налоговый период, налоговую ставку, порядок исчисления налога, порядок и сроки уплаты налога. Субъекты РФ вправе изменять их только в случаях, предусмотренных законом. Основные налоговые методы, используемые субъектами РФ, - налоговые ставки и налоговые льготы. Эти методы должны использоваться в комплексе. Такой инструмент, как налоговые ставки, используется регионами, как правило, в инвестиционных целях. С помощью налоговых льгот может достигаться решение следующих задач:

- выполнение органами власти субъектов РФ своих социальных функций, например, предоставление льгот организациям, созданным инвалидами для реабилитации инвалидов. Также с помощью налоговых льгот могут предоставляться преференции организациям, которые предоставляют рабочие места молодежи и студентам;

- сохранение в структуре экономики региона убыточных производств или предприятий сферы услуг, которые имеют важное значение. Так, льготы могут предоставляться предприятиям ЖКХ, общественного транспорта, организациям, занимающимся фундаментальной наукой, и т. д. 
- поддержка инвестиционных проектов, которая позволяет инвесторам в течение некоторого времени после начала реализации проекта не уплачивать налоги.

Возможно также предоставление льгот организациям малого бизнеса и индивидуальным предпринимателям на определенный период времени, чтобы они могли занять свое место на рынке.

В мировой практике существуют инструменты налогового регулирования, которые пока не получили широкого распространения в России. Так, для стимулирования инвестиций капитального характера применяются инвестиционные налоговые скидки. Они представляют собой сумму капитальных вложений предпринимателей, которая вычитается из облагаемого налогом дохода. Некоторым аналогом такой скидки в российском законодательстве является амортизационная премия, которая, однако, не является налоговым инструментом, находящимся в компетенции субъектов РФ, поскольку ее применение или неприменение от их воли не зависит. Также в мировой практике широкое распространение имеет исследовательский кредит (скидки на НИОКР), который был бы актуален в России.

Следующий налоговый инструмент - налоговые каникулы (освобождение налогоплательщика на определенный период времени от уплаты налога) в усеченном виде имел место и в России. Российское законодательство имело опыт предоставления налоговых каникул в части налога на прибыль (малым предприятиям) и налога на имущество организаций. Такая льгота действовала до принятия Второй части НК РФ. В настоящее время режим налоговых каникул предусмотрен для налога на имущество, земельного и транспортного налога для организации особой экономической зоны (ОЭ3), но полного освобождения от налогов не предусматривается.

Таким образом, основные инструменты налогового регулирования экономики регионов сосредоточены на уровне федеральных органов власти. В силу значительности территории и разного уровня экономического развития субъектов РФ это снижает возможности по учету особенностей каждого субъекта РФ. Необходимо расширение полномочий субъектов РФ в части регулирования природопользования, рынка строительства, предоставления льгот инвесторам в самых разных отраслях экономики.

Большинство налоговых доходов субъектов РФ являются отчислениями от федеральных налогов. Первоначально они поступают в федеральный бюджет, а затем перераспределяются между субъектами РФ. По мнению исследователей, возможно расширение перечня региональных и местных налогов, например, за счет налога на доходы физических лиц и некоторых видов акцизов.

Субъекты РФ недостаточно эффективно используют свои полномочия. Основными налоговыми методами, как указывалось выше, являются налоговые ставки и налоговые льготы. Налоговые льготы в основном носят социальный характер и призваны смягчить налоговое бремя для социально незащищенных граждан, вместе с тем они также могут способствовать инвестиционной активности. При этом практически не используется такой метод, как изменение сроков уплаты налогов и сборов, и особенно такой налоговый инструмент, как инвестиционный налоговый кредит. Отчасти это связано с позицией налоговых органов, без согласия которых данный инструмент применяться не может. Налоговые органы имеют своей целью максимизацию налоговых поступлений 
в бюджет, а предоставление отсрочек и рассрочек эти поступления снижает. В этой части пересмотр полномочий субъектов РФ и федеральных органов власти необходим, поскольку в части региональных налогов, полностью поступающих в бюджет субъекта Федерации, целесообразно предоставление регионам права самостоятельно определять возможность изменения срока уплаты налога или сбора.

В Российской Федерации наблюдается значительное расслоение субъектов по уровню налоговых доходов, следовательно, и по возможности регулирования экономики регионов с помощью налоговых методов. Применение налоговых инструментов в экономически неблагополучных регионах ограничено тем, что регионы, в силу дефицита бюджета, не могут позволить себе предоставления существенных налоговых льгот или снижения налоговых ставок, поскольку это повлечет за собой снижение доходной базы региона.

Государственные заказы как инструмент фискального финансового регулирования экономики выполняют ряд важнейших функций. Используя государственные заказы и закупки, государство привлекает потенциал частного предпринимательства для обеспечения устойчивости экономического развития, решения актуальных социально-экономических задач [42]. В этом случае в процессе воздействия системы государственных заказов на экономику наряду со стимулирующим возникает и синергетический эффект.

Мировая практика показывает, что в развитых экономических странах государственные заказы широко используются как инструмент поддержки экономической и социальной стабильности, обеспечения поступательного роста экономики. Через механизм размещения и выполнения государственных заказов создается рынок государственных заказов (закупок). На этом рынке через систему государственных контрактов устанавливаются и реализуются финансовоэкономические связи государства-заказчика с хозяйственными субъектами различных форм собственности.

Можно выделить ряд социально-экономических особенностей контрактных отношений на рынке государственных заказов.

Во-первых, вся деятельность в рамках контрактов осуществляется на средства бюджетов, внебюджетных источников финансирования и регламентируется условиями контрактного договора, сметами расходов и другими документами.

Во-вторых, сформирована особая система ценообразования и стимулирования, предполагающая развитую дифференцированную типологию контрактов на все виды товаров и услуг.

В-третьих, государственные заказы могут сопровождаться определенными социально-экономическими условиями (например, привлечение субъектов малого предпринимательства, организаций инвалидов и т. д.).

Таким образом, вся совокупность контрактных отношений, формирующихся в процессе размещения и реализации государственных заказов, имеет целенаправленное финансовое регулирование.

В нашей стране государственный контракт заключается в порядке, предусмотренном Гражданским кодексом РФ, Бюджетным кодексом РФ и соответствующими федеральными законами. Под государственным контрактом понимается договор, заключенный заказчиком от имени РФ, субъекта РФ в целях обеспечения государственных нужд. 
Созданная в России в начале 1990-х гг. для выполнения государственных заказов Федеральная контрактная система была реформирована в 1994 г., так как оказалась неэффективной (выполнение работ слабо подкреплялось государственным финансированием). Проблема формирования конкурентной, эффективной системы государственных заказов стала особенно актуальной в связи с активизацией финансово-экономической роли государства, что потребовало реализации комплекса мер, направленных на реформирование системы государственных заказов по следующим направлениям [42]:

1. Развитие нормативной правовой базы государственного рынка товаров и услуг.

2. Регламентация всей цепочки (правил, порядка и процедур) государственных закупок.

3. Создание системы оперативного контроля и аудита проведения конкурсных процедур, эффективности бюджетных расходов.

Принятые меры способствовали повышению экономности и эффективности расходования финансовых средств, выделяемых на государственные закупки. Вместе с тем на федеральном и региональном уровнях система государственных заказов имеет следующие общие проблемы:

- нечеткость и несогласованность отдельных нормативных правовых актов в трактовке норм и правил распределения бюджетных средств, предусмотренных законодательством;

- несовершенство системы прогнозирования и планирования на этапе подготовки бюджета, приводящее к затягиванию сроков проведения конкурсов и перерасходу бюджетных средств;

- сложности информационного обеспечения размещения госзаказов;

- отсутствие эффективного контроля за выполнением правил размещения заказов;

- отсутствие профессионально подготовленных специалистов.

В то же время в последние два года наблюдается положительная динамика объема государственных закупок в соответствии с Федеральным законом № 44-Ф3 [43]. За период 2017-2018 гг. объем закупок для государственных нужд вырос на треть, при этом объем закупок по Федеральному закону № 223-Ф3 [44], активно росший в 2015-2017 гг., в 2018 г. показал существенное снижение на $30 \%$ (рис. 7).

В России доля государственных расходов на закупку товаров, работ, услуг для государственных нужд по отношению к ВВП ниже, чем в странах Евросоюза (15-20 \% ВВП), США (около $15 \%$ ). В России же аналогичный показатель в 2011-2014 гг. находился на уровне 5-10\%.

В настоящее время на региональном уровне происходит активизация деятельности по развитию процедур размещения государственного заказа. В ряде субъектов РФ сформировались институциональные основы по развитию регионального рынка государственных заказов и проведению конкурентных конкурсных процедур. На региональном уровне активно формируется инфраструктура рынка государственных заказов как система взаимосвязанных элементов, важнейшими из которых являются: управляющие центры; современные информационноаналитические системы (сайты в Интернете, реестры контрактов и закупок, базы данных поставщиков, постоянно действующие выставки); учебные и консультационные структуры; некоммерческие структуры, созданные поставщиками для защиты своих прав и интересов на рынке госзакупок. 


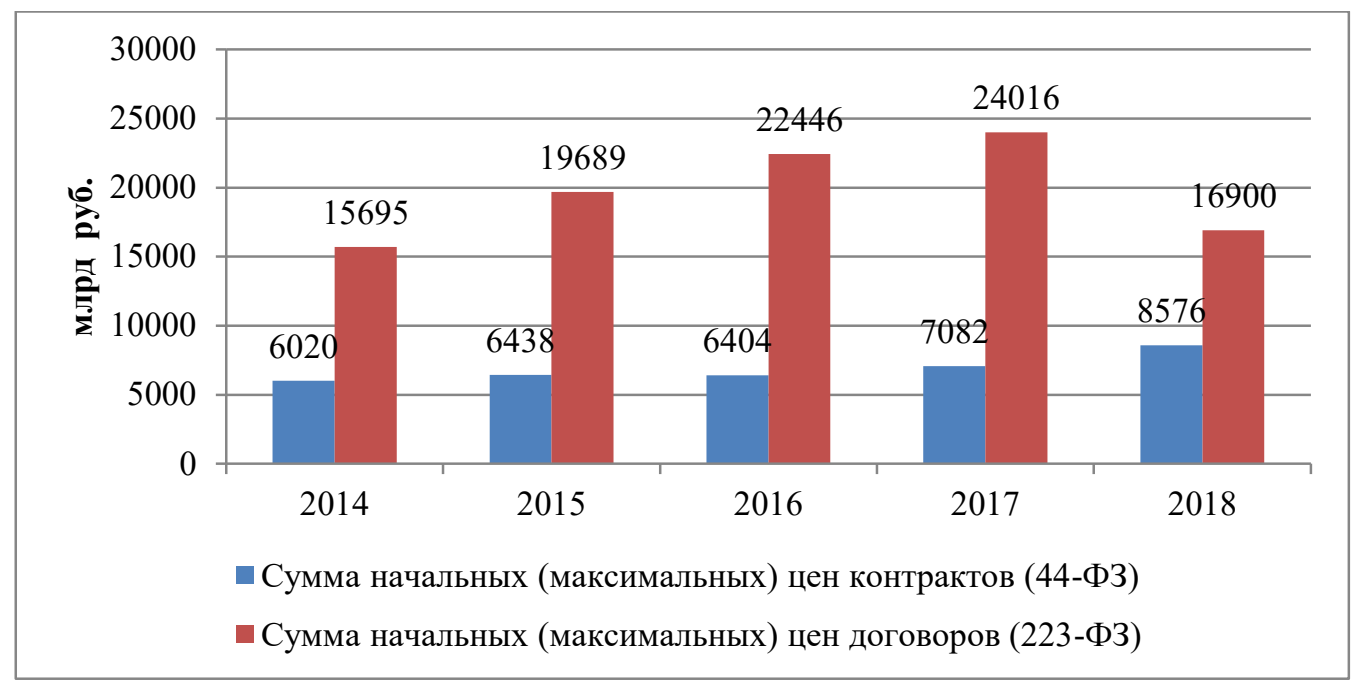

Рис. 7. Сумма начальных (максимальных) цен контрактов и договоров размещенных извещений, 2014-2018 гг., млрд руб. ${ }^{5}$

Вместе с тем остается еще много нерешенных проблем. Рост количественных показателей государственных заказов в отдельных регионах характеризуется заметной неравномерностью. Динамика объемов заказов по субъектам РФ во многом зависит от реализации крупных региональных инфраструктурных проектов. Остаются нерешенными и многие вопросы нормативного регулирования государственных заказов. Одной из важных проблем является заключение долгосрочных контрактов. Бюджетный кодекс РФ предусмотрел возможность заключать долгосрочные контракты на работы и услуги, длительность оказания которых составляет более одного года. К таким работам и услугам относятся изыскательские, научно-исследовательские и опытно-конструкторские работы, работы по созданию новых медицинских технологий и т. д. Возникающие сложности при существующем порядке исполнения бюджетных обязательств в рамках текущего финансового года затягивают процесс принятия данного вида контрактов.

Существенной проблемой на сегодняшний день является отсутствие научно обоснованных методов оценки финансово-экономической эффективности решений в сфере государственных закупок.

Все более актуальной в настоящее время становится проблема управления финансовыми ресурсами системы государственного заказа, т. е. формирования организационных, финансово-экономических условий и механизмов для наиболее эффективного их использования.

Решение этих задач представляется особенно важным в связи с тем, что возрастает объем средств, инвестируемых государством через систему государственных заказов в долгосрочные капиталоемкие проекты.

Анализ мирового и отечественного опыта доказывает, что система государственных заказов, наряду с бюджетной и налоговой системой, выступает важнейшим инструментом государственного финансового регулирования развития экономики, науки и техники, обеспечения высоких темпов

\footnotetext{
${ }^{5}$ По данным экспертного доклада «Система закупок в России» за 2018 г. [45].
} 
экономического роста. Система государственных закупок является не просто эффективной и прозрачной формой использования бюджетных средств, обеспечивающей результативность расходов, а одним из инструментов управления и финансового регулирования экономики страны и ее регионов.

\section{3. Содержание, оценка и управление финансовым потенциалом региона}

Россия представляет собой совокупность крайне различающихся между собой по уровню экономического развития регионов. И эти различия все более усиливаются. В связи с этим становятся все более актуальными задача определения внутренних резервов и факторов экономического развития и задача качественной оценки потенциальных и реальных региональных возможностей в целях эффективного управления финансовыми ресурсами территорий, формирования эффективной и адекватной региональной политики.

Используемые в России на протяжении последних десятилетий инструменты государственного финансового регулирования были направлены в первую очередь на повышение управляемости региональными процессами и централизацию финансовых потоков [46]. Такая политика привела к финансовой зависимости территорий от федерального центра, неспособности региональных органов власти в полной мере реализовывать финансовый потенциал субъектов РФ, утрате интереса к поиску форм и методов повышения финансовой привлекательности регионов. Сложившиеся финансовые механизмы в регионах ориентированы в основном на наполнение бюджета, в т. ч. за счет безвозмездных перечислений с вышестоящих уровней. Инструментам повышения ресурсной базы, формирования развитой финансовой инфраструктуры и достижения финансовой независимости региона уделяется недостаточное внимание. Следует отметить также существенную региональную асимметрию [47], которая выражается в неравномерной обеспеченности регионов финансовыми ресурсами.

Устойчивое социально-экономическое развитие Российской Федерации невозможно без обеспечения сбалансированного развития субъектов РФ, которое включает:

- создание эффективной экономики регионов на базе формирования современной производственной, транспортной, жилищно-коммунальной и другой инфраструктур;

- развитие социальной сферы, обеспечивающей благоприятные условия жизнедеятельности населения;

- устранение диспропорций социально-экономического развития субъектов Российской Федерации.

Реализация указанных мероприятий во многом зависит от наличия и возможности создания или привлечения ресурсов, прежде всего финансовых.

В настоящее время просматривается тенденция передачи части полномочий с федерального уровня на региональный. Для полноценной реализации полномочий и формирования условий для социально-экономического развития субъектов РФ региональным органам власти нужно создать достаточную финансовую базу, то есть обеспечить различные субъекты регионального хозяйства необходимыми финансовыми ресурсами. Данная задача предполагает, во-первых, рациональную оценку потребности субъектов в финансовых ресурсах, во-вторых, создание действенного механизма вовлечения потенциальных источников финансовых ресурсов в региональное хозяйство. 
В условиях одновременных процессов глобализации и регионализации экономики, интеграционных процессов, необходимости выполнения задач по повышению финансового самообеспечения, усиления конкурентных преимуществ постановка проблем формирования и использования финансовых ресурсов региона является сама по себе недостаточной. Кроме того, принятие важнейших управленческих решений и построение финансового механизма на уровне региона не может базироваться на простом подсчете объема финансовых ресурсов и не даст ожидаемых результатов.

Оценить потенциальную и реальную финансовую базу региона как совокупность имеющихся финансовых ресурсов позволяет методология расчета финансового потенциала.

Использование в экономической теории и практике данного понятия позволяет сопоставить финансовые возможности разных регионов, полноценно оценить эффективность региональных финансов, комплексно судить о финансовой обеспеченности задач стратегического развития, выявить финансовую самодостаточность региона, выработать экономическую, социальную, финансовую, бюджетную и налоговую политику.

В целом под потенциалом в научной литературе понимаются источники, возможности, средства, запасы, которые могут быть использованы для решения какой-либо задачи, достижения определенной цели.

Под потенциалом региона следует понимать систему взаимосвязанных, взаимообусловленных и взаимодействующих факторов, обеспечивающих эффективное развитие региона как в современных условиях, так и на перспективу.

Потенциал региона - понятие многогранное и комплексное. Как правило, в структуру потенциала региона включают такие составляющие, как природный потенциал, экономический потенциал и социальный потенциал. Каждый из данных элементов можно также разделить на несколько составляющих.

Финансовый потенциал, наряду с производственным, институциональным, инфраструктурным, входит в структуру экономического потенциала.

В настоящий момент очевидна необходимость определения финансового потенциала на уровне каждого региона. Функционирование, обеспечение взаимодействия и перспективного развития экономики региона в значительной степени зависит от состояния и способности региона самостоятельно финансировать свою жизнедеятельность, определять направления развития и их приоритеты для обеспечения финансовой устойчивости, сбалансированности финансовых показателей и наращивания экономической ресурсной базы. Уровень финансового обеспечения региона, в свою очередь, характеризует именно финансовый потенциал.

Актуальность оценки финансового потенциала территорий определяется тем, что от его динамики, объема и качества зависит уровень развития территории, стабильность политической ситуации, условия жизни населения, а также возможность государственного финансового регулирования социальноэкономических процессов посредством финансовых ресурсов, находящихся в распоряжении органов власти региона.

Оценка финансового потенциала может служить мерой сравнения возможностей формирования финансовых ресурсов регионов, а также основой для разработки направлений развития региональной финансовой сферы. 
Оценка финансового потенциала необходима для построения эффективной системы межбюджетных отношений в РФ. Традиционно используемыми показателями при его оценке являются:

- потенциальная кредитоспособность хозяйственного комплекса (отношение просроченной кредиторской и дебиторской задолженности по хозяйственному комплексу региона);

- бюджетная результативность (доходы на душу населения);

- бюджетная обеспеченность региона (расходы бюджета региона на душу населения);

- уровень дотационности региона;

- уровень региональных и местных налогов и налоговых льгот.

Перечисленные показатели легли в основу некоторых методик оценки финансового потенциала территории (региона) как авторских, так и официальных, имеющих безусловную теоретическую и практическую значимость, но в большей степени направленных на оценку устойчивости бюджета как главного источника ресурсной базы региона, не рассматривая при этом иные источники средств.

Исследования, проводимые различными авторами по данной проблеме, касаются сферы формирования и регулирования финансового потенциала, но зачастую они носят бессистемный характер, не учитывают элементы, составляющие целостность этого понятия. Основной акцент делается на формирование и использование бюджетно-налогового потенциала, и полностью игнорируется или слабо учитывается потенциал кредитных и страховых организаций, инвестиционных компаний и фондов, населения. Как следствие, нет единства и в определении понятия «финансовый потенциал», применяются разные подходы к определению сущности и состава финансового потенциала, не разработана модель, оценивающая финансовый потенциал региона.

Некоторые авторы современных публикаций [48] включают в финансовый потенциал не все ресурсы, а только те, которые обеспечивают инвестиционный процесс, другие - только те ресурсы, которые участвуют в формировании бюджета, не учитывая финансовые ресурсы, которые находятся в частном секторе и у домохозяйств [49], то есть финансовый потенциал близок к определению бюджетного потенциала. Третьи исследователи - по сравнению с двумя предыдущими - не учитывают даже неналоговые доходы бюджетов, то есть, согласно их точке зрения, финансовый потенциал - аналог налогового потенциала. Отличаются приведенные подходы и объектами, которые предлагается учитывать для расчета финансового потенциала [50].

В настоящее время известно три основных подхода к трактовке финансового потенциала региона:

1. Структурный подход подразумевает рассматривать сущность категории «финансовый потенциал региона» как сумму составляющих его потенциалов - налогового, бюджетного, страхового, кредитного и др. Данных взглядов придерживаются В. Н. Лексин, А. Н. Швецова и Ж. И. Голодова.

2. Ресурсный подход, при использовании которого термин «финансовый потенциал региона» трактуется как совокупность финансовых ресурсов. К сторонникам данного подхода можно отнести А. Л. Коломийца, А. Д. Мельника, С. В. Зенченко, О. И. Тишутину и др. 
3. Результативный подход, позволяющий увидеть в содержании данного термина определенный набор условий для обеспечения регионального экономического развития. К сторонникам данного подхода следует отнести Н. М. Сабитову, Г. С. Мерзликину, Л. С. Шаховскую.

На основании изучения различных подходов к пониманию категории «финансовый потенциал» представляется, что финансовый потенциал должен включать в себя не только финансовые ресурсы, которыми располагает регион в настоящее время, но и те финансовые средства, которые могут быть привлечены для выполнения функций регионального уровня власти. Финансовый потенциал региона зависит от наличия различных видов ресурсов, которыми он располагает независимо от того, используются они или нет.

По нашему мнению, региональный финансовый потенциал необходимо определять как совокупность количественных и качественных характеристик, включающих совокупный объем аккумулированных на территории региона финансовых ресурсов, в свою очередь включающих финансовые ресурсы бюджетной системы, ресурсы региональной банковской системы, собственные средства предприятий, привлеченные ресурсы и сбережения населения.

В более общем значении под финансовым потенциалом региона можно понимать предпосылки к региональному экономическому развитию за счет формирования, привлечения и использования финансовых ресурсов в различных секторах регионального хозяйства.

Структурно-финансовый потенциал состоит из налогово-бюджетного потенциала, финансового потенциала населения, финансового потенциала коммерческих и некоммерческих организаций, зарегистрированных на территории региона, и потенциала кредитно-финансовой системы региона с учетом внешних инвестиций и кредитных ресурсов.

Сложный характер трактовки финансового потенциала региона требует рассмотрения данной категории под разными углами исследования. Так, следует выделять:

- накопленный финансовый потенциал (сформированный на протяжении предыдущих периодов времени) и текущий финансовый потенциал (фактически годовой прирост финансового потенциала);

- используемый финансовый потенциал (вовлеченный в обеспечение эффективного функционирования финансовой системы региона) и неиспользуемый (потенциально возможный для вовлечения в хозяйственно-экономические процессы в регионе).

В российской экономической системе единой методики, оценивающей финансовый потенциал региона, не разработано.

Отсутствие однозначных подходов к трактовке дефиниции «финансовый потенциал» в научной среде приводит к необходимости поиска теоретических и практических методических основ к его количественной оценке.

Анализ современной литературы позволил выделить несколько наиболее часто упоминаемых методик оценки финансового потенциала. Были выделены и сопоставлены следующие методики: методика С. В. Зенченко [51], методика О. И. Тишутиной [52], методика Ж. И. Голодовой [53].

В табл. 4 представлен сравнительный анализ подходов, предлагаемых данными авторами, к трактовке и количественной оценке категории «финансовый потенциал региона». 
Сравнение различных подходов к трактовке и оценке категории «финансовый потенциал»

\begin{tabular}{|c|c|c|c|}
\hline Критерий & $\begin{array}{c}\text { Методика } \\
\text { С. В. Зенченко }\end{array}$ & $\begin{array}{c}\text { Методика } \\
\text { О. И. Тишутиной }\end{array}$ & $\begin{array}{c}\text { Методика } \\
\text { Ж. И. Голодовой }\end{array}$ \\
\hline $\begin{array}{l}\text { Подход } \\
\text { к трактовке категории } \\
\text { «финансовый потенциал» }\end{array}$ & Ресурсный & Ресурсный & Структурный \\
\hline Общий механизм расчета & $\begin{array}{l}\text { Абсолютный показатель, } \\
\text { характеризующий } \\
\text { стоимостную оценку } \\
\text { ресурсов, включаемых } \\
\text { в финансовый потенциал }\end{array}$ & $\begin{array}{l}\text { Относительный показатель, } \\
\text { характеризующий сумму } \\
\text { значений уровневых } \\
\text { индексов по каждому блоку }\end{array}$ & $\begin{array}{l}\text { Относительный показатель, } \\
\text { характеризующий сумму } \\
\text { значений уровневых индексов } \\
\text { по каждому блоку }\end{array}$ \\
\hline Используемые методы & $\begin{array}{l}\text { Статистическая и экспертная } \\
\text { оценка }\end{array}$ & Метод «Паттерн» & $\begin{array}{l}\text { Использование уровневых } \\
\text { и интегральных показателей }\end{array}$ \\
\hline $\begin{array}{l}\text { Количество } \\
\text { выделяемых блоков }\end{array}$ & $\begin{array}{l}4 \text { блока } \\
\text { (бюджетный налоговый, } \\
\text { кредитный, } \\
\text { инвестиционный) }\end{array}$ & $\begin{array}{l}2 \text { блока } \\
\text { (финансовый, экспортный) }\end{array}$ & $\begin{array}{l}6 \text { блоков } \\
\text { (потенциал предприятий } \\
\text { и организаций, бюджетно- } \\
\text { налоговый, кредитный, } \\
\text { страховой, инвестиционный, } \\
\text { потенциал домашних хозяйств) }\end{array}$ \\
\hline $\begin{array}{l}\text { Количество } \\
\text { используемых показателей }\end{array}$ & $\begin{array}{l}\text { Может варьироваться } \\
\text { в зависимости от вида } \\
\text { определяемого финансового } \\
\text { потенциала }\end{array}$ & $\begin{array}{l}6 \text { основных показателей } \\
\text { (3 по блоку «финансовый } \\
\text { потенциал» и } 3 \text { по блоку } \\
\text { «экспортный потенциал») }\end{array}$ & Более 20 показателей \\
\hline $\begin{array}{l}\text { Сфера } \\
\text { практического применения }\end{array}$ & $\begin{array}{l}\text { Регионы Южного } \\
\text { федерального округа }\end{array}$ & $\begin{array}{l}\text { Приграничные регионы } \\
\text { Дальневосточного } \\
\text { федерального округа }\end{array}$ & $\begin{array}{l}\text { Субъекты Уральского } \\
\text { федерального округа }\end{array}$ \\
\hline
\end{tabular}


Окончание таблицьь 4

\begin{tabular}{|c|c|c|c|}
\hline Критерий & $\begin{array}{c}\text { Методика } \\
\text { С. В. Зенченко }\end{array}$ & $\begin{array}{c}\text { Методика } \\
\text { О. И. Тишутиной }\end{array}$ & $\begin{array}{c}\text { Методика } \\
\text { Ж. И. Голодовой }\end{array}$ \\
\hline Достоинства & $\begin{array}{l}\text { Позволяет рассчитать } \\
\text { как текущий, } \\
\text { так и накопленный } \\
\text { финансовый потенциал }\end{array}$ & $\begin{array}{l}\text { Для расчета финансового } \\
\text { потенциала используются } \\
\text { интегральные уровневые } \\
\text { характеристики }\end{array}$ & $\begin{array}{l}\text { Учет большого числа факторов, } \\
\text { формирующих финансовый } \\
\text { потенциал. } \\
\text { Дана интерпретация } \\
\text { получаемых значений } \\
\text { в ходе расчета финансового } \\
\text { потенциала } \\
\end{array}$ \\
\hline Недостатки & $\begin{array}{l}\text { Недостаточное внимание } \\
\text { уделено кредитной } \\
\text { и инвестиционной } \\
\text { составляющим. } \\
\text { Требует дополнительной } \\
\text { адаптации для практического } \\
\text { применения }\end{array}$ & $\begin{array}{l}\text { Модель скорректирована } \\
\text { для сравнения приграничных } \\
\text { регионов. } \\
\text { Модель использует } \\
\text { ограниченное количество } \\
\text { показателей }\end{array}$ & $\begin{array}{l}\text { Необходимость } \\
\text { экспертной оценки } \\
\text { по некоторым показателям } \\
\text { модели }\end{array}$ \\
\hline
\end{tabular}


В первых двух методиках сущность финансового потенциала рассматривается с ресурсной позиции, третья трактует финансовый потенциал с позиции структурного подхода, при этом для количественной оценки финансового потенциала во всех трех методиках выделяются отдельные блоки.

С. В. Зенченко выделяет 4 блока (бюджетный, налоговый, кредитный, инвестиционный потенциал), ограничиваясь расчетом объемной (стоимостной) оценки финансового потенциала.

О. И. Тишутина предлагает определять финансовый потенциал как суммарную оценку 2 блоков (непосредственно финансового и экспортного).

Ж. И. Голодова рассматривает финансовый потенциал как совокупность 6 блоков (потенциал предприятий и организаций, бюджетно-налоговый, кредитный, страховой, инвестиционный потенциалы, потенциал домашних хозяйств).

При этом в последних двух методиках кроме объемных характеристик определяются уровневые показатели финансового потенциала, позволяющие проводить сравнение и осуществлять группировку регионов.

Авторами были проведены апробации предлагаемых методик: С. В. Зенченко проводит оценку финансового потенциала по регионам Южного федерального округа [51]; О. И. Тишутина приводит расчеты по приграничным субъектам Дальневосточного федерального округа [52]; Ж. И. Голодова дифференцирует регионы Уральского федерального округа [53].

Проведенное сравнение позволяет выделить следующие закономерности построения расчетных моделей, описывающих финансовый потенциал:

- отсутствие единых подходов к построению расчетного механизма;

- выделение различного количества блоков и показателей при определении количественных характеристик финансового потенциала;

- адаптация моделей к специфике отдельных групп регионов (выбор которых обусловлен научными интересами исследователей);

- необходимость дальнейшего изучения возможностей применения разработанных моделей на практике.

Обобщение приведенных подходов позволяет нам сделать ряд утверждений относительно содержания расчетного механизма финансового потенциала.

Для характеристики финансового потенциала предлагается использовать показатели - объем финансового потенциала и уровень финансового потенциала. Они могут быть рассчитаны на основании приведенных формул.

При оценке финансового потенциала следует выделять совокупность следующих блоков:

- бюджетно-налоговый потенциал (Пб-н);

- потенциал хозяйствующих субъектов (Пхс);

- потенциал домохозяйств (Пдх);

- потенциал финансово-кредитной сферы (Пф-к)

Финансовый потенциал в абсолютном выражении может быть определен по формуле

Пфин $=$ Пб-н + Пдх + Пхс + Пф-к.

Уровень финансового потенциала в относительном выражении может быть определен по формуле:

Пфин $=\sqrt[4]{ } \sqrt{ }\left(K_{\text {интегр }}(\right.$ Пб-н $) \cdot K_{\text {интегр }}($ Пдх $) \cdot K_{\text {интегр }}(П х с) K_{\text {интегр }}($ Пф-к) $)$. 
Соответственно, для оценки совокупного финансового потенциала необходимо определить вышеуказанные показатели по каждому структурному элементу. Методика расчета показателей по каждому указанному блоку представлена в табл. 5.

Таким образом, расчет бюджетно-налогового потенциала базируется на таких показателях, как общий объем бюджетных доходов и расходов региона, сумма собственных доходов, величина трансфертов; расчет потенциала домохозяйств основан на таких показателях, как доходы физических лиц, проживающих на территории региона, доля сбережений и потребления в структуре доходов, а также величина прожиточного минимума в регионе.

Расчет потенциала хозяйствующих субъектов основан на таких показателях, как сальдированный финансовый результат хозяйствующих субъектов, объем амортизационных отчислений, рентабельность хозяйствующих субъектов региона, доля неубыточных предприятий.

Расчет потенциала финансово-кредитной сферы основан на определении инвестиционных возможностей экономических субъектов региона, на уровне развития финансовой инфраструктуры, а также на основных показателях банковской системы.

Для проведения объективной оценки финансового потенциала и эффективной интерпретации полученных результатов необходимо учитывать следующие принципы:

- систематизация сбора и обобщения показателей по каждому выделенному в структуре финансового потенциала региона блоку;

- проведение дополнительного факторного анализа по структурным блокам, позволяющего выявить влияние изменения отдельных элементов на динамику финансового потенциала;

- корректное сопоставление показателей финансового потенциала между регионами в условиях незначительных отличий при подсчете значений элементов системы оценки в отдельных субъектах РФ.

Большое значение при оценке финансового потенциала конкретного региона играет определение его используемой и неиспользуемой частей. В качестве неиспользуемого финансового потенциала следует выделять объем ресурсов, не задействованный в финансовом кругообороте региона в настоящий момент, но при этом он может быть вовлечен в региональную хозяйственную систему в будущем. Используемая часть финансового потенциала эта та часть, которая по состоянию на текущий момент реализована и участвует в облуживании хозяйственных процессов региона.

На возможность вовлечения в хозяйственный оборот региона финансового потенциала, не используемого в настоящий момент, влияют объективные и субъективные факторы.

К объективным факторам можно отнести уровень развития регионального финансового рынка, сложившуюся структуру хозяйства, наличие в регионе ресурсной базы и т. д.

К субъективным факторам отнесем целенаправленную деятельность региональных органов власти по формированию благоприятной финансовой среды в регионе, включающей в себя меры инвестиционной, институциональной и инфраструктурной направленности. 
Методика расчета показателей

по четырем блокам финансового потенциала региона

\begin{tabular}{|c|c|}
\hline Бюджетно-налоговый потенциал региона (Пб-н) & Потенциал домашних хозяйств (Пдх) \\
\hline $\begin{array}{l}\text { В абсолютном выражении: } \\
\text { Пб-н = НП + ННП + ТР - РО, } \\
\text { где НП - налоговые источники, формируемые регионом; } \\
\text { ННП - неналоговые источники, привлекаемые регионом; } \\
\text { ТР - межбюджетные трансферты; } \\
\text { РО - расходные обязательства. } \\
\text { В относительном выражении: } \\
\quad K_{\text {интегр }}\left(\text { Пб-н) }=4 \sqrt{ } \sum K_{i},\right. \\
\text { где } K_{i} \text { - индивидуальные показатели, характеризующие } \\
\text { бюджетно-налоговый потенциал }\left(K_{1}, K_{2}, K_{3} \text { и } K_{4}\right) ; \\
K_{1} \text { - коэффициент покрытия расходов; } \\
K_{2} \text { - коэффициент концентрации собственных доходов; } \\
K_{3} \text { - коэффициент обеспеченности населения } \\
\text { собственными бюджетными доходами; } \\
K_{4} \text { - коэффициент отношения доходов к величине } \\
\text { межбюджетных трансфертов }\end{array}$ & 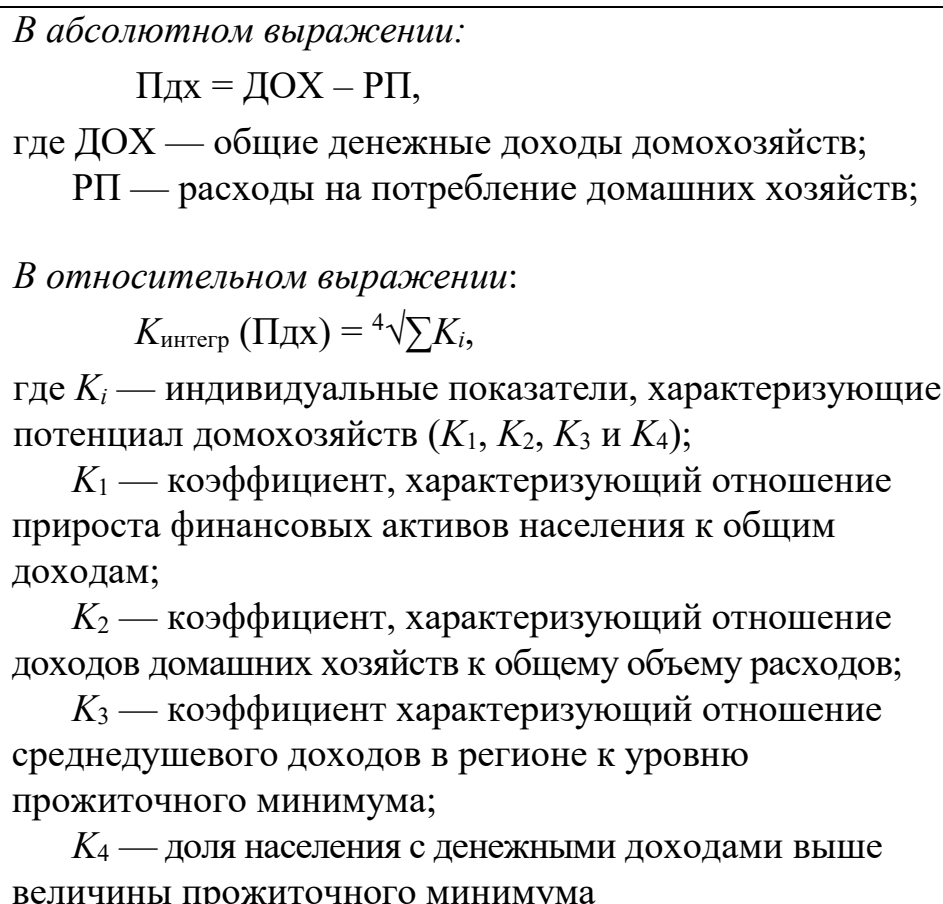 \\
\hline
\end{tabular}




\begin{tabular}{|c|c|}
\hline Потенциал хозяйствующих субъектов (Пхс) & Потенциал финансово-кредитной сферы (Пф-к) \\
\hline 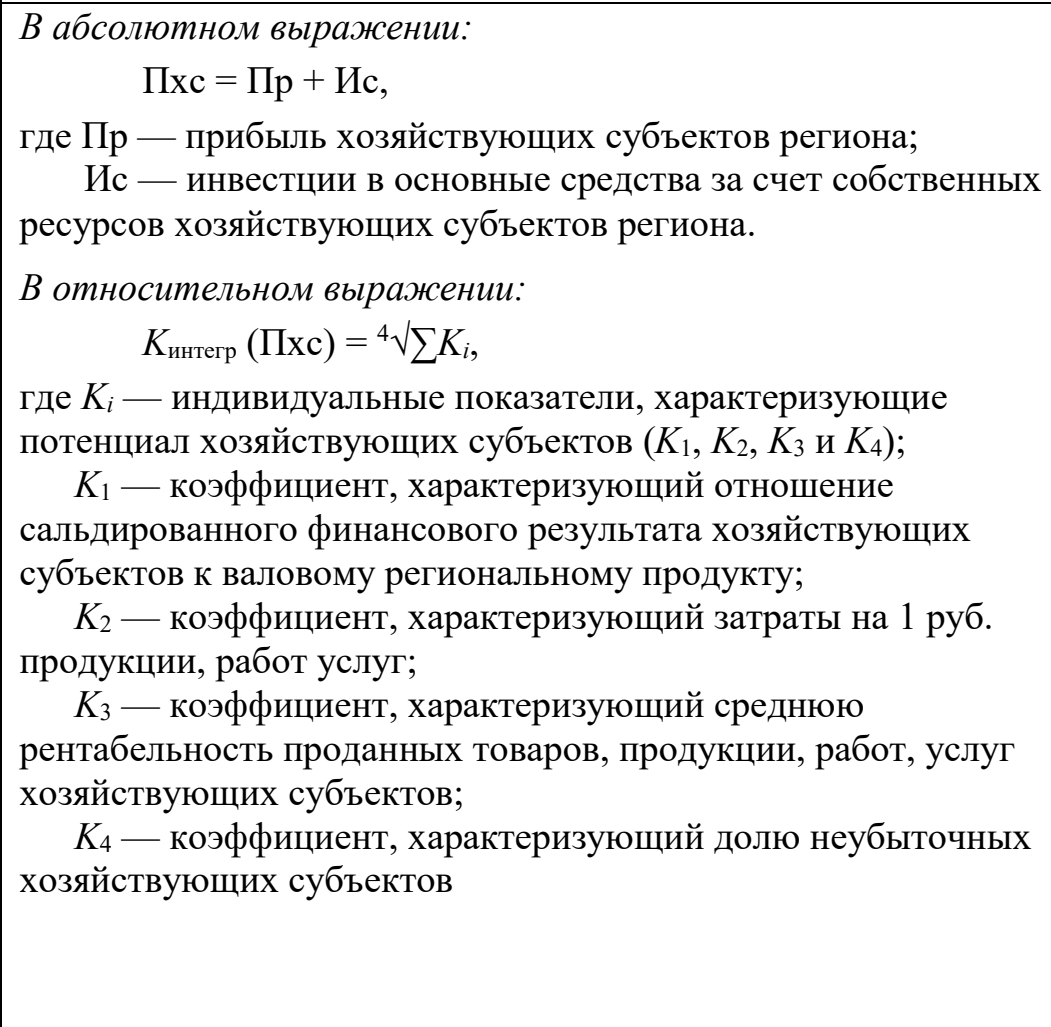 & 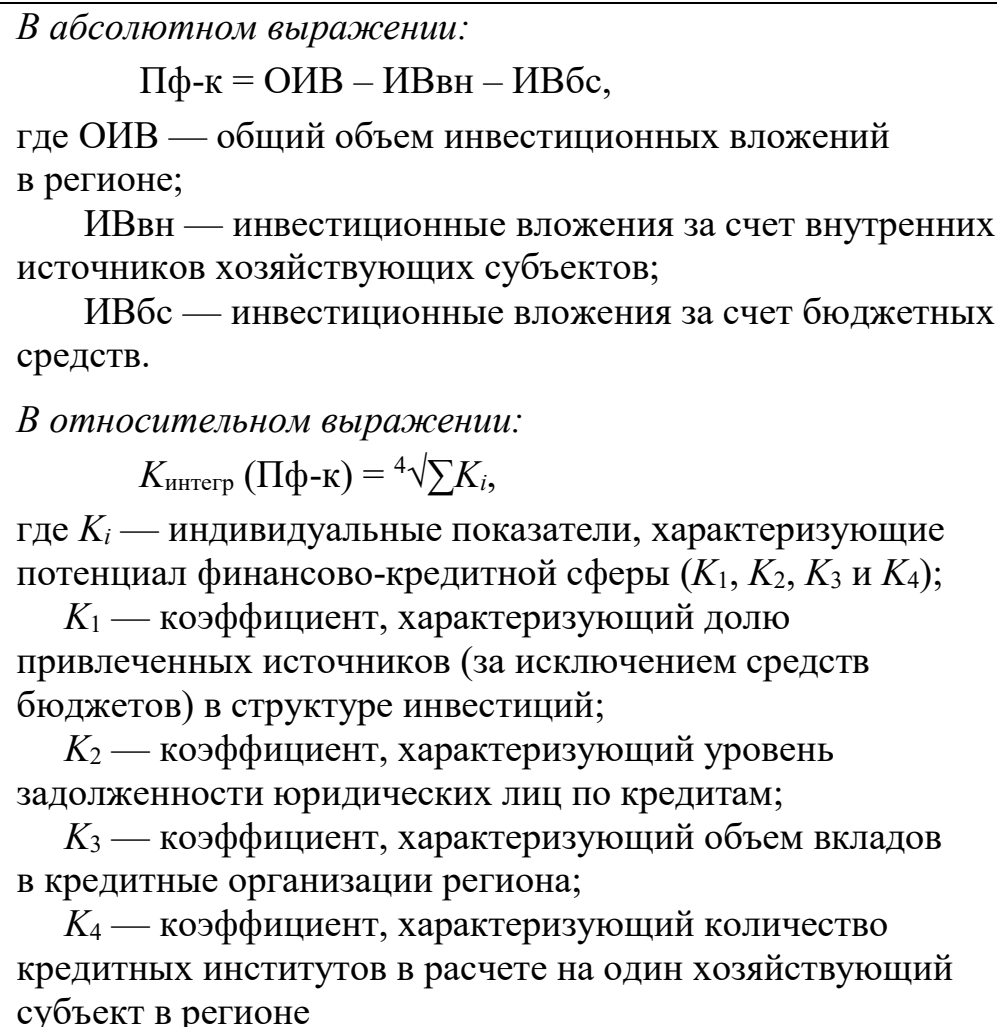 \\
\hline
\end{tabular}


На основе оценки финансового потенциала регионов могут решаться следующие основные задачи:

- с помощью количественной характеристики финансового потенциала можно проводить группировку регионов для выявления наиболее финансово сильных при построении системы или оценке результатов межбюджетных расчетов;

- определение возможности размещения тех или иных облигационных займов на территории различных регионов;

- определение финансового потенциала региона может стать основой разработки сводных программ и стратегий развития территорий;

- финансовый потенциал региона может выступать в качестве одной из характеристик, рассматриваемых при возможности реализации тех или иных программ и проектов, при выборе наиболее привлекательных с этой точки зрения регионов и т. д.

Корректная оценка финансового потенциала и вовлечение в региональный финансовый механизм не используемого ранее финансового потенциала позволяет достичь более высоких темпов социально-экономического развития региона и поставленных стратегических целей.

Кроме того, проведение оценки финансового потенциала региона дает возможность определить уровень устойчивости социально-экономического развития территории, ее способность к достижению финансовой самообеспеченности, а также выявить предпочтительные инструменты и рычаги формирования и использования финансовых ресурсов региона, наращивания совокупной ресурсной базы и укрепления финансового потенциала.

Оценка финансового потенциала является одним из базисов при принятии управленческих решений в области региональных финансов.

Полученная оценка финансового потенциала региона как комплексного индикатора, оценивающего способность региона к формированию собственной ресурсной базы, обеспечивающей развитие территории, является наиболее обоснованным отражением качества системы регионального управления и выполнения требований федеральных программ по региональному развитию.

Количественная оценка финансового потенциала дает возможность проводить группировку регионов с целью выявления наиболее финансово сильных при построении системы или оценке результатов межбюджетных расчетов.

Учет типологии региона по уровню финансового потенциала позволит региональным властям более обоснованно принимать управленческие решения, разрабатывать направления, стимулирующие развитие наиболее проблемных составляющих ресурсной базы, а федеральным властям укажет на целесообразность пересмотра политики регионального выравнивания с позиций усиления и укрепления накопленного регионами финансового потенциала и стимулирования формирования финансового потенциала у не обеспеченных ресурсами регионов.

Для повышения эффективности финансового регулирования на уровне регионов и дифференциации выбора рычагов воздействия на пропорции экономического развития территорий представляется обоснованным использование расчета количественных характеристик общего финансового потенциала субъектов РФ и по отдельным его составляющим. В современной практике принятия управленческих решений, вероятно, будут востребованы: исследования динамики показателей финансового потенциала по отдельным регионам и их 
группам; сравнение интегральных показателей финансового потенциала и проведение на основе полученных значений ранжирования территорий со схожими характеристиками хозяйства; сопоставление уровня достигнутого финансового развития территории при условии максимального использования имеющихся ресурсов [54].

В рассмотренном контексте становится ясной необходимость управления финансовым потенциалом, которое можно определить, с одной стороны, как систему принципов и методов разработки и реализации управленческих решений, направленных на формирование финансового потенциала и повышение эффективности его использования всеми субъектами экономики - государством, регионами, отдельными предприятиями и организациями, домашними хозяйствами. $\mathrm{C}$ другой стороны, управление финансовым потенциалом представляет собой комплексное воздействие на его элементы, направленное на повышение величины и эффективности использования потенциала, достижение экономической устойчивости и стабильности в стране и ее регионах, улучшение благосостояния граждан и качества их жизни. Другими словами, управление финансовым потенциалом должно осуществляться непрерывно на всех уровнях с учетом особенностей и данного региона, и текущего момента, а также с учетом воздействия внешних нерегулируемых на уровне региона факторов.

Субъектами управления финансовым потенциалом являются федеральные и региональные органы власти, надзорные органы финансово-банковской системы, стратегические и оперативные органы управления предприятий и организаций, население, саморегулируемые организации и ассоциации.

Финансовый потенциал реализуется для обеспечения регионов необходимыми финансовыми ресурсами - собственными, заемными и полученными в порядке перераспределения, стимулирования субъектов финансовой системы к увеличению финансовых потоков, контроля за процессом формирования, распределения и использования финансовых ресурсов, страхования от возможных угроз.

Управление финансовым потенциалом региона должно базироваться на следующих взаимосвязанных и взаимообусловленных принципах, позволяющих добиться максимальной эффективности используемого потенциала в целях обеспечения устойчивости социально-экономического развития региона как элемента национальной экономики:

- принцип системности и комплексности;

- принцип целевой направленности на достижение финансовой самодостаточности;

- принцип синхронности развития макро-, мезо- и микроуровней, направленный на создание условий для повышения экономической и социальной эффективности деятельности хозяйствующих субъектов, финансово-банковских институтов, домашних хозяйств, которые в конечном итоге будут способствовать развитию регионов и национального хозяйства страны в целом;

- принцип адаптации к изменениям внешней среды, направленный на извлечение максимальной выгоды от использования позитивных факторов и тенденций мега- и макроуровня путем корректировки принимаемых решений и реализуемых мер воздействия, а также на создание механизмов защиты от проявления негативных факторов и тенденций; 
- принцип достижения сбалансированности финансовых ресурсов и потребностей в них у всех субъектов экономики региона;

- принцип стратегической гибкости, обеспечивающий выделение приоритетных целей и направлений деятельности, их подцелей и задач;

- принцип частно-государственного и социального партнерства, позволяющий гармонизировать интересы государства, частного бизнеса и населения, проживающего на территории данного региона, в части создания и развития производственной и социальной инфраструктуры, улучшения экологической ситуации, повышения уровня благосостояния и уровня занятости;

- принцип аккумуляции временно свободных финансовых ресурсов, вовлечение которых будет способствовать увеличению финансового потенциала региона и его субъектов и, как следствие, их инвестиционных возможностей;

- принцип экономической безопасности, обеспечивающий защиту от возможных объективных (возникающих без участия региона и помимо его воли) и субъективных (имеющих место в результате умышленных или неумышленных действий различных субъектов) угроз;

- принцип стимулирования, предполагающий заинтересованность всех сторон в достижении максимального результата — увеличение финансовых потоков и повышение эффективности их использования;

- принцип транспарентности, позволяющий получить достоверную и полную информацию о финансовых потоках всех субъектов экономики региона.

Управление финансовым потенциалом должно включать в себя основные направления:

1. Управление формированием финансового потенциала и его элементов. Это может быть осуществлено с помощью различных методов и инструментов: разработка необходимой законодательной базы, использование государственного заказа для формирования платежеспособного спроса на внутреннем рынке, стимулирование развития отдельных отраслей и сфер, развитие банковских и небанковских кредитных организаций, страхового рынка и рынка ценных бумаг, повышение доходов населения и др. Необходимо обеспечить финансовую устойчивость экономики региона, закрепив за ним соответствующие источники доходов, в том числе и налоговые.

2. Управление использованием финансового потенциала для финансирования текущих и капитальных затрат, направленное на повышение результативности и эффективности деятельности. В данном случае речь идет о наличии: реалистичной стратегии развития региона, выделении статей расходов, соответствующих полномочиям, которые выполняет регион; приоритетных инвестиционных проектов, которые прошли соответствующую процедуру отбора и финансируются за счет средств регионального или федерального бюджета.

3. Управление наращиванием финансового потенциала, направленное на повышение потенциала за счет внутренних возможностей и привлечения средств инвесторов других регионов и стран. Это направление предполагает создание условий для повышения финансового результата деятельности субъектов экономики, повышения сбережений населения, что обеспечит региону в дальнейшем стабильное развитие.

4. Управление финансовыми отношениями, возникающими в процессе формирования и использования потенциала между государством и региональными органами власти и управления, между органами власти и субъектами экономики, 
т. е. юридическими и физическими лицами. Это направление предполагает, прежде всего, совершенствование механизма межбюджетных отношений, нацеленного, с одной стороны, на сокращение дифференциации бюджетной обеспеченности, с другой - на стимулирование региональной активности.

5. Управление возникающими в процессе формирования, использования и наращивания финансового потенциала рисками и угрозами, ориентированное на создание фондов и резервов, используемых в условиях ухудшения параметров внешней и внутренней среды.

Более подробно элементы управления финансовым потенциалом, а также в целом концепция управления финансовым потенциалом с включающими в себя блоками представлены в исследованиях Ж. Г. Голодовой [55].

Эффективность управления финансовым потенциалом во многом зависит от определенных приоритетов финансовой политики региона и ее основных составляющих - бюджетной, налоговой, банковской, а также политики развития рынка ценных бумаг, страхового рынка.

В практике финансового регулирования на основе оценки финансового потенциала и его составляющих возможно обоснование управленческих решений по следующим инструментам и рычагам воздействия на региональное развитие:

- изменение подходов к выделению межбюджетных трансфертов, в т. ч. и в отношении их структуры (дотаций, субсидий, субвенций), на основе оценки бюджетно-налоговой составляющей финансового потенциала региона;

- повышение самостоятельности регионов в области формирования налоговой политики за счет расширения базы региональных налогов, увеличения диапазона принимаемых решений по вопросам определения налоговых ставок, предоставляемых налоговых льгот — на основе оценки финансового потенциала коммерческих и некоммерческих организаций;

- исследование возможности применения региональных инвестиционнозаемных систем на основе выпуска ценных бумаг, в т. ч. с доступом к ним населения, и путем оценки финансового потенциала домохозяйств и потенциала кредитно-финансовой системы региона;

- определение соотношения источников финансирования целевых региональных программ, направленных на достижение стратегических целей развития территорий, в разрезе бюджетов различных уровней — на основе оценки совокупного финансового потенциала региона.

Возможности субъектов Российской Федерации в формировании финансового потенциала различны в силу природно-климатических условий, сложившейся системы разделения труда и структуры экономики, уровня развития производства и т. д.

Неэффективное использование имеющихся в арсенале органов власти финансовых рычагов не лучшим образом влияет на формирование и реализацию финансового потенциала. Также не способствует повышению финансовой обеспеченности регионов нерациональная структура распределения налоговых доходов между звеньями бюджетной системы и существующая практика бюджетного выравнивания, система налоговых льгот. Устойчивое функционирование и, тем более, развитие экономики и социальной сферы субъектов РФ невозможно без государственной поддержки и государственного финансового регулирования. 
Финансовая политика должна включать методы и инструменты финансового регулирования с учетом факторов, определяющих специфику, место региона в едином народнохозяйственном комплексе и перспективы его развития.

В целом, оценка финансового потенциала территории должна являться основной управления и перераспределения финансовых потоков между всеми участниками экономической системы региона: органами власти, хозяйствующими субъектами, финансово-кредитными институтами и домохозяйствами. Выявление наиболее перспективных элементов хозяйства региона с точки зрения возможности генерирования финансовых ресурсов, которые можно привлечь для обеспечения экономического роста субъекта РФ, должно способствовать созданию в регионе обоснованной системы финансовых инструментов развития и повышению эффективности использования рычагов финансирования инвестиционной деятельности.

В конечном итоге анализ количественных и качественных характеристик финансового потенциала отдельных субъектов РФ должен позволить сформировать дифференцированный подход к реализации региональной финансовой политики и разработке индивидуальных подходов к финансовому регулированию с учетом специфики финансовых систем территорий и их способности формировать необходимые финансовые ресурсы в различных секторах экономики. 


\section{2. НАПРАВЛЕНИЯ И ИНСТРУМЕНТЫ РЕАЛИЗАЦИИ ФИНАНСОВОГО РЕГУЛИРОВАНИЯ СЕВЕРНЫХ ТЕРРИТОРИЙ В РОССИИ И ЗА РУБЕЖОМ}

\section{1. Финансовое регулирование развития северных территорий в зарубежных странах}

В России региональное финансовое регулирование осуществляется в специфических условиях: в силу климатических условий, исторических традиций, неравномерности размещения природных ресурсов существуют заметные существенные диспропорции в экономическом и финансовом потенциалах отдельных регионов. По этим причинам в России выработка принципов реализации регионального финансового регулирования, дифференциации подходов для различных групп регионов требует изучения возможных эффектов применения и значительного экономического обоснования.

Особенно тщательно следует подходить к выбору инструментов и рычагов финансового регулирования в регионах, чьи территории полностью или частично находятся в зоне Крайнего Севера и которые характеризуются сложными социально-экономическими условиями жизни населения, смещением пропорций развития региональных хозяйств в сторону добывающих производств, ограниченным финансовым потенциалом (см. подробнее: [56]). При выборе эффективных инструментов регулирования финансовых процессов в данных субъектах необходимо использовать уже накопившийся отечественный опыт, а также зарубежный опыт формирования и реализации регионального финансового регулирования и применения финансовых рычагов развития северных территорий.

В настоящее время в число стран, чья территория частично относится к зоне Крайнего Севера, входит восемь государств: Россия, Канада, Финляндия, Дания, Норвегия, США, Швеция, Исландия. Следует уточнить, что под территорией Крайнего Севера (Арктики) здесь понимаются прстранства, расположенные за Северным полярным кругом 6 . Каждая из приведенных стран имеет ту или иную долю площадей, находящихся в арктической зоне, но при этом в мире нет ни одной страны, которая бы полностью была расположена за полярным кругом. В табл. 6 приведены данные, характеризующие арктическую принадлежность рассматриваемых стран.

Канада является второй после России страной в мире по площади территории и самой близкой по природно-климатическим условиям и географическому расположению. По форме своего государственного устройства Канада является федерацией. Она имеет достаточно сложную систему территориально-административного деления, предполагающего выделение территориальных единиц по административному и по переписному принципу.

${ }^{6}$ В мировой практике за границу Арктики, как правило, принимается: 1) июльская изотерма $10{ }^{\circ} \mathrm{C}$, ограничивающая территорию, где возможна летняя вегетация растений; 2) северная граница распространения лесов; 3) Северный полярный круг. 
Характеристики арктической принадлежности стран *

\begin{tabular}{|c|c|c|c|c|c|c|c|c|}
\hline Показатели & Россия & Канада & США & Норвегия & Финляндия & Швеция & Дания & Исландия \\
\hline Площадь, млн км² & 17,12 & 9,98 & 9,52 & 0,32 & 0,34 & 0,45 & 0,04 & 0,10 \\
\hline $\begin{array}{l}\text { Доля территорий, } \\
\text { приходящихся } \\
\text { на арктическую } \\
\text { зону, млн км² }(\%)\end{array}$ & $3,1(18)$ & $3,4(35)$ & $\begin{array}{l}0,65 \\
(6,8)\end{array}$ & $0,17(54)$ & $0,10(29)$ & $0,10(22)$ & $2,13(98)$ & Менее 1 \\
\hline $\begin{array}{l}\text { Земли и регионы, } \\
\text { относимые } \\
\text { к арктической зоне }\end{array}$ & $\begin{array}{l}\text { Архангельская } \\
\text { и Мурманская } \\
\text { обл.; республика } \\
\text { Коми } \\
\text { и Саха (Якутия); } \\
\text { Ненецкий, } \\
\text { Ямало-Ненецкий, } \\
\text { и Чукотский АО; } \\
\text { Красноярский край }\end{array}$ & $\begin{array}{l}\text { Северо- } \\
\text { Западные } \\
\text { территории, } \\
\text { Юкон, } \\
\text { Нунавут }\end{array}$ & Аляска & $\begin{array}{l}\text { Финнмарк, } \\
\text { Тромс, } \\
\text { Нурланн, } \\
\text { Шпицберген }\end{array}$ & Лапландия & Норботтен & Гренландия & $\begin{array}{l}\text { О-ов Гримсей и } \\
\text { территориальные } \\
\text { воды у северного } \\
\text { побережья } \\
\text { страны }\end{array}$ \\
\hline Население, млн. чел. & 146,7 & 35,04 & 324,3 & 5,28 & 5,47 & 9,84 & 5,67 & 0,33 \\
\hline 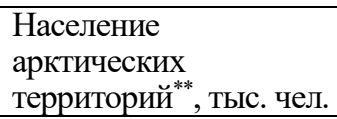 & 2502 & 120 & 710 & 466 & 184 & 260 & 58 & $<0,5$ \\
\hline $\begin{array}{l}\text { Доля населения, } \\
\text { проживающего } \\
\text { на арктических } \\
\text { территориях, \% }\end{array}$ & 1,7 & 0,3 & 0,2 & 8,8 & 3,4 & 2,6 & 1,0 & - \\
\hline
\end{tabular}

* Возникающие при определении численности населения и площади территорий трудности связаны: с отсутствием официально установленных южных границ районов Арктической зоны; с поиском достоверных статистических современных данных по населению арктических областей, провинций, губерний, муниципальных образований других стран; с существующими различными подходами к определению границ Арктики.

** Данные приведены согласно [57]. 

субъектов:

В рамках административного принципа в Канаде выделяют четыре уровня

- 10 провинций и 3 территории (провинции, по сути, независимы от федерального центра и друг от друга, территории же близки по степени самостоятельности к субъектам в РФ);

- регионы и области (данный уровень в некоторых провинциях и территориях утвержден официально, например, Квебек, Северо-Западные территории, частично Нунавут, в других же деление на области номинальное).

- графства и округа (фактически представляют собой, как и деление на регионы и области, второй уровень территорий; официально деление на графства и округа закреплено в 6 провинциях);

- административные уровни муниципального уровня (к ним относятся муниципалитеты, города, деревни, приходы, кантоны и т. д.; выделение муниципальных структур характерно для всех провинций и территорий Канады);

- индейские резервации (данные структурные единицы не относятся ни к одному из уровней территориального деления, наделены достаточно широким объемом самостоятельности и представляют собой своеобразный отдельный уровень субъектов).

Большинство административных единиц Канады находятся в суровых климатических условиях. Так, 75 \% территории этой страны представляет собой зону Севера, около 35 \% арктические площади (часть Северо-Западных территорий, территорий Юкон и Нунавут). По плотности населения Канада сопоставима с северными регионами России (средняя плотность по стране составляет около 3,5 чел/км²). В настоящее время провинции в Канаде обладают достаточно широкими финансовыми правами и полномочиями.

Одним из основных инструментов финансового обеспечения развития территорий, в том числе северных, в Канаде являлись региональные программы. Их активное формирование и реализация начались в 1950-1960 гг. (наиболее эффективными программами, реализованными в то время в Канаде, считаются программы «Лицом к Северу» и «Дорога к ресурсам»). Как правило, программы носили комплексный характер по развитию ряда территориальных образований и включали не только прямое финансирование крупных инвестиционных проектов в области добычи ресурсов на развиваемых территориях, но и определенные финансовые льготы, позволяющие привлечь частный бизнес.

В настоящее время разработкой и реализацией программ развития северных провинций и территорий Канады занимается Канадское агентство экономического развития северных территорий (Canadian Northern Economic Development Agency). Агентство способствует росту и развитию северных территорий путем реализации программ экономического развития и сотрудничества, a также координирует деятельность других федеральных органов власти в области политики развития Севера Канады. В последние годы Агентство реализовывало следующие целевые программы развития северных территорий: «Стратегические инвестиции в экономическое развитие северных территорий Канады (Sined)», «Возможности экономического развития коренных сообществ Севера Канады (NAEOP), «Северная программа базового образования для взрослых (NABEP)», «Общественный фонд “Улучшение инфраструктуры” 
(CIIF)», «Поддержка и продвижение языков национальных меньшинств Севера». Общий ежегодный объем финансирования по программам составляет в настоящий момент более 150 млн канад. долл. [58].

Помимо государственных программ для устранения различий в уровне развития между провинциями и территориями, в Канаде активно применяется выделение наиболее слаборазвитым административным субъектам финансовых ресурсов с помощью трансфертов. Через систему трансфертов провинциям и территориям перераспределяется порядка 20-25\% расходов федерального бюджета.

В Канаде на современном этапе развития применяется два вида межбюджетных трансфертов. Первый вид - нецелевые трансферты, предоставляемые провинциям и территориям для выравнивания бюджетной обеспеченности. Все три субъекта Канады, территории которых входят в арктическую зону, характеризуются достаточно низкими показателями финансовой обеспеченности и являются получателями нецелевых выравнивающих трансфертов. Второй вид межбюджетных трансфертов целевые, они направлены на обеспечение выполнения стандартов в наиболее важных социальных отраслях, таких как здравоохранение и социальная сфера.

В 2016-2017 гг. провинции и территории Канады через бюджетные трансферты получили 70,9 млрд канад. долл. Только за последние десять лет объем федеральной поддержки за счет трансфертов вырос в 1,5 раза.

В табл. 7 представлены некоторые характеристики федеральной поддержки арктических территорий Канады через систему межбюджетных трансфертов в 2016-2017 гг.

В совокупном объеме выделяемых межбюджетных трансфертов на долю территорий Юкон, Нунавут и Северо-Западные территории приходится в общей сложности лишь $5 \%$, но при этом размер межбюджетного трансферта в расчете на одного жителя по указанным территориям более чем в 10 раз превышает средние значения по стране (в среднем по северным субъектам приходится около 25 тыс. долл. США на человека). Также следует отметить, что в отличие от общей структуры межбюджетных трансфертов в структуре трансфертов арктическим территориям ключевое место занимают нецелевые перечисления.

Канада на протяжении последних лет входила в лидеры по привлечению иностранных инвестиций. Несмотря на это, в стране наблюдается существенная дифференциация провинций и территорий по объемам привлекаемых инвестиций. Для устранения различий в начале 2000 -х гг. в Канаде было создано государственное агентство по поддержке инвестиций в регионы Канады, его основной задачей является поддержка и сопровождение инвесторов, готовых вкладывать финансовые средства в наименее привлекательные регионы страны.

Финансовые рычаги формирования доходов (налоговые и неналоговые) в Канаде замыкаются в большей части на уровень провинций и территорий, что создает в этой стране достаточно уникальную ситуацию: совокупные доходы тринадцати территориальных единиц превышают доходы федерального уровня. При этом в последние два десятилетия в целом прослеживается слабо выраженная, но достаточно устойчивая тенденция к дальнейшему расширению финансовых прав субъектов в области формирования собственных доходов бюджетов. 
Некоторые характеристики федеральной поддержки арктических территорий Канады* через систему межбюджетных трансфертов в 2016-2017 гг.

\begin{tabular}{|c|c|c|c|c|c|c|}
\hline \multirow{3}{*}{ Территории } & \multirow{3}{*}{$\begin{array}{c}\text { Совокупные } \\
\text { межбюджетные } \\
\text { трансферты (МТ), } \\
\text { млрд канад. долл. }\end{array}$} & \multirow{3}{*}{$\begin{array}{c}\text { Доля } \\
\text { в совокупных } \\
\text { МТ, } \%\end{array}$} & \multirow{3}{*}{$\begin{array}{l}\text { Размер МТ } \\
\text { в расчете } \\
\text { на } 1 \text { жителя, } \\
\text { канад. долл. }\end{array}$} & \multicolumn{3}{|c|}{ Доля по видам межбюджетных трансфертов, \% } \\
\hline & & & & \multicolumn{2}{|c|}{ Целевые } & \multirow{2}{*}{$\begin{array}{c}\text { Нецелевые } \\
\text { (на поддержку территорий } \\
\text { и бюджетное выравнивание) }\end{array}$} \\
\hline & & & & здравоохранение & $\begin{array}{c}\text { социальная } \\
\text { сфера }\end{array}$ & \\
\hline $\begin{array}{l}\text { По всем провинциям } \\
\text { и территориям }\end{array}$ & 70,9 & 100 & 1958 & 50,9 & 18,8 & 30,4 \\
\hline $\begin{array}{l}\text { Территории, } \\
\text { расположенные } \\
\text { в зоне Арктики } \\
\end{array}$ & 3,77 & 5 & & 3,1 & 1,2 & 95,6 \\
\hline в т. ч. Юкон & 0,95 & 1,3 & 25258 & 3,9 & 1,5 & 94,2 \\
\hline $\begin{array}{l}\text { Северо- } \\
\text { Западные } \\
\text { территории } \\
\end{array}$ & 1,28 & 1,8 & 28777 & 3,4 & 1,3 & 95,3 \\
\hline Нунавут & 1,54 & 2,2 & 41554 & 2,4 & 0,9 & 96,7 \\
\hline
\end{tabular}

* Данные департамента финансов Канады [59] 
Специфика построения налоговой системы Канады способствует высокому значению доли налоговых поступлений в бюджеты провинций и территорий (в федеральный бюджет поступает около $50 \%$ от общей совокупности взимаемых в стране налогов, в бюджеты провинций и территорий около 32-33 \%, остальная доля приходится на бюджеты муниципальных образований).

Обобщая опыт Канады в области финансового регулирования северных территорий, следует отметить высокий уровень их самостоятельности в вопросах использования финансовых инструментов, а также наличие большого количества приоритетных программ по развитию северных административных субъектов, финансируемых на федеральном уровне. При этом, несмотря на все принятые меры, Канаде не удалось в полной мере добиться значительного снижения различий в уровне развития северных территорий и столичных регионов.

Соединенные Штаты Америки отнесены к арктическим странам благодаря штату Аляска. Все остальные территории страны располагаются южнее Северного полярного круга.

Аляска - самый большой штат США, его площадь составляет 1,72 млн км², население - более 735 тыс. чел. По плотности населения Аляска занимает последнее - 50-е место среди штатов США.

Аляска имеет достаточно специфическую структуру хозяйства, в котором определяющую роль играет наличие природных ресурсов. Данный штат занимает заметное место по объемам добычи золота, серебра, цинка, свинца. Но главная отрасль промышленности Аляски - это нефтедобыча. В настоящий момент здесь получают до $20 \%$ общеамериканской добычи (Аляска по показателям нефтедобычи уступает в последние годы лишь Техасу). Чтобы оценить важность данной отрасли для экономики Аляски, достаточно сказать, что около $50 \%$ занятых в экономике так или иначе связаны с нефтяной промышленностью.

Одной из основных особенностей построения финансовых отношений между федеральным уровнем и территориями в США является предоставление значительных полномочий отдельным штатам. В связи с этим власти штата обладают высокой степенью самостоятельности в области финансового регулирования и финансового обеспечения.

Объем доходной части бюджета штата Аляска в 2015 г. составил около 13 млрд долл. США [62], что, например, почти в 5 раз больше, чем совокупные доходы бюджета Республики Саха, которая больше Аляски по площади практически в 2 раза и сопоставима с ней по населению.

Большая часть доходов бюджета формируется за счет поступлений от компаний, занятых в нефте- и газодобыче на территории штата (порядка 50$60 \%$ от общего размера доходов), на долю межбюджетных трансфертов из федерального бюджета приходится 20-25\%, оставшуюся часть формируют налоговые поступления. Такой объем поступлений от добычи полезных ископаемых позволяет Аляске иметь уникальную систему налогообложения, характеризующуюся незначительным количеством налогов и сниженными ставками. По уровню налоговой нагрузки на физических лиц Аляска относится к штатам с минимальными значениями показателей, при этом по сравнению с другими штатами Западного побережья США, она имеет самые высокие показатели сбора налогов на душу населения (в 2014 г. данный показатель составил 4603 долл. на одного человека) [60]. 
Межбюджетные трансферты от федерального правительства выделяются Аляске для финансирования различных совместных программ, в основном в виде перечислений на развитие здравоохранения, образования и транспорта. В 2014 г. размер межбюджетных трансфертов в расчете на одного человека составил около 4 тыс. дол. США (это, к примеру, более чем в 5 раз меньше аналогичного сопоставимого показателя по северным территориям в Канаде). На каждый доллар налогов в последние годы Аляска получает примерно 1,8-2,0 долл. федеральных трансфертов и по данному соотношению входит в тройку наиболее самостоятельных штатов США (еще несколько десятков лет назад по данному показателю она не входила даже в первую десятку лидеров среди штатов) [61].

Для повышения уровня жизни населения и роста инвестиционной активности на Аляске используются и уникальные инструменты финансового рынка. Так, был создан Постоянный фонд штата Аляска (Alaska Permanent Fund), который пополняется за счет отчислений от платежей за использование минеральных ресурсов штата, прежде всего нефтяных, трансфертов, выделяемых Аляске и т. д. Ежегодно фонд осуществляет выплату в несколько тысяч долларов каждому жителю штата, включая детей. Кроме того, предполагается, что средства фонда могут быть использованы для развития Аляски после исчерпания минеральных ископаемых на ее территории.

Несмотря на то, что финансовое регулирование в США в отношении Аляски в целом является одним из самых эффективных, позволяющих данной северной территории активно развиваться, увеличивать численность населения и обеспечивать благоприятные предпосылки для обеспечения экономического развития в будущем, в последний период она испытывает серьезные финансовые трудности из-за существенного падения цен на нефть и другие сырьевые ресурсы. Тогда же существенно возрос дефицит бюджета (в 2016 г. дефицит бюджета Аляски составил порядка 4 млрд долл. США). В 2016 г. властями был разработан план по оптимизации бюджета штата, его основные пункты: сокращение расходов, реструктуризация использования средств Постоянного фонда, умеренное повышение налогов, налоговая реформа в области поступлений от нефте- и газодобычи [62].

Достаточно интересен опыт финансового регулирования арктических зон в Дании. В состав этой страны на правах автономной территории входит Гренландия, где находится самая северная в мире точка суши. Гренландия является крупнейшим островом в мире, при этом численность его населения составляет около 60 тыс. человек. Хозяйство автономии специализируется на отраслях рыболовства, добычи полезных ископаемых, туризма. Следует отметить, что в Гренландии велика доля государственного и муниципального секторов в экономике.

Остров имеет права широкой автономии в составе Дании, обладает собственными органами исполнительной и законодательной власти. Среди сфер, регулируемых на государственном уровне, следует отметить внешнюю политику, оборону, валютную политику, деятельность полиции и судов. Остальные сферы находятся под управлением властей автономии.

Несмотря на то, что в последние годы создаются условия для повышения финансовой самостоятельности данной автономии (так, в 2009 г. было принято решение о передачи Данией острову всех прав на добычу природных ресурсов), 
Гренландия является высокодотационным субъектом Дании. Государственные субсидии из бюджета Дании («блоковая помощь») составляют около трети ВВП автономии (ежегодная сумма финансовых трансфертов составляет примерно 500 млн евро). В пересчете на душу населения размер межбюджетных трансфертов острову составляет около 10 тыс. долл. США на человека, что в 2 раза выше, чем, например, на Аляске, но ниже аналогичных показателей по северным территориям в Канаде. В законе, регламентирующем оказание финансовой помощи Гренландии (Закон № 473 «О расширенной автономии Гренландии» от 21 июня 2009 г.), указывается, что субсидии будут перечисляться автономии до тех пор, пока доходы от разработки полезных ископаемых острова не перекроют их.

Следует отметить, что органы власти Гренландии достаточно самостоятельны при реализации налоговой политики. В отличие от непосредственно территории Дании, где уровень налогообложения даже по европейским меркам высок, в автономии установлен широкой перечень налоговых скидок и льгот для инвесторов, что позволяет привлекать активно частный капитал для реализации крупных промышленных и инфраструктурных проектов.

Финансовое обеспечение развития Гренландии осуществляет не только Дания, но и Европейский союз, с которым у автономии заключен ассоциированный договор. Средства Европейского союза идут в основном на реализацию крупных инфраструктурных проектов острова.

Между ЕС и Гренландией договором установлены и другие преференции. Так, остров имеет право неограниченного ввоза морепродуктов на территорию союза без уплаты таможенных пошлин, а ЕС имеет право привилегированного доступа в морскую зону автономии.

В Финляндии к арктическим территориям относится только Лапландия. По площади Лапландия является крупнейшей областью страны (ее территория составляет 92,6 тыс. км²), население составляет около 180 тыс. чел. Одновременно данный регион характеризуется наиболее низкой плотностью населения

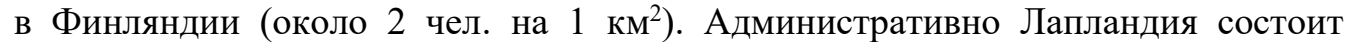
из 21 общины (из них 4 городские, а остальные сельские), которые объединены в 6 районов.

Лапландия относится к наименее благополучным регионам Финляндии, по показателю ВВП регион уступает примерно в 2 раза наиболее развитым южным областям страны. Существенная дифференциация регионов Финляндии по уровню экономического развития складывалась исторически. Ее причиной являлись значительные природно-климатические различия по областям, близость южных регионов к финансово-промышленным центрам Европы.

Активную политику регионального финансового регулирования Финляндия начала реализовывать в 1960-е гг. Основным инструментом регулирования являлись краткосрочные программы развития, включавшие в себя субсидирование сельского хозяйства, реализацию инфраструктурных и социальных проектов. В это же время были приняты законы, утвердившие разделение страны на развитые (промышленные) регионы и развивающиеся - отстающие по социально-экономическим показателям. Во вторую группу, наряду с несколькими северными и восточными областями, вошли и территории Лапландии. 
С начала 1970-х характер применяемых для развития отстающих регионов страны финансовых инструментов заметно меняется. На первый план выходят налоговые льготы и сниженные процентные ставки по кредитам, в том числе за счет государственного субсидирования, для субъектов хозяйствования на данных территориях. В это же время в качестве рычагов развития получили распространение проекты по повышению качества проживания и подготовки трудовых ресурсов в северных и восточных территориях.

С середины 1970-х в Финляндии была реализована двухуровневая система регионального планирования, в соответствии с которой органы власти сознательно ограничивали развитие южных промышленных областей с целью переориентации капитала и трудовых ресурсов в менее развитые регионы. Одним из инструментов такой политики стал дополнительный налог на инвестиции, введенный в южных регионах страны.

Для повышения привлекательности ведения бизнеса в северных регионах были введены целевые субсидии, позволяющие предпринимателям компенсировать затраты на подготовку и использование рабочей силы.

С конца 1970-х для развития неблагополучных северных областей в Финляндии используется формирование точек роста, которые смогли бы стать своеобразными локомотивами развития определенных регионов.

В 1980-е гг. приоритеты региональной финансовой политики начали смещаться в сторону реализации внутреннего инновационного потенциала северных областей, развития традиционных для них видов деятельности. Была повышена степень финансовой самостоятельности регионов. Немалую роль в данном процессе сыграл закон «О развитии регионов», принятый в 1993 г. Но в сравнении с некоторыми другими арктическими автономиями объем полномочий северных областей Финляндии существенно ограничен.

С 1990-х гг. и до настоящего времени основным финансовым инструментом, применяемым для развития северных территорий, являются целевые программы. Вступление Финляндии в ЕС в 1995 г. позволило повысить финансирование региональных программ развития северных и восточных территорий страны за счет средств фондов развития Евросоюза. В 1999 г. был создан Финнвера - специализированный фонд для стимулирования компаний, действующих в развивающихся областях (прежде всего, таких как Кайнуу, Сатакунта, Похьойс-Саво и Лапландия) (см. подробнее: [63]).

В последние годы в Лапландии реализуются целевые программы, способствующие занятости населения и сокращению безработицы (финансируются государственным бюджетом Финляндии), программы по стимулированию реализации инновационных проектов и поддержки новых и растущих компаний (за счет средств европейских фондов).

Помимо программных инструментов в настоящее время для развития северных территорий применяются такие финансовые инструменты, как непосредственное выделение коммунам субсидий, софинансирование крупных инвестиционных проектов компаний.

Бюджет Лапландии состоит из бюджетов коммун, входящих территориально в данный регион. Около половины доходов бюджетов коммун Лапландии образуют налоговые поступления. Муниципальные органы власти в Финляндии обладают достаточно широким объемом полномочий в области формирования местных налоговых систем (основными местными налогами 
в настоящий момент являются налог на заработную плату жителей муниципалитетов, налог на городскую недвижимость и другое имущество, также в бюджет коммун перечисляется часть налога на прибыль предприятий). Налоги с физических лиц в муниципалитетах Финляндии составляют порядка 85-90\% [64]. Налоги и ставки по ним устанавливаются муниципальными советами (без необходимости одобрения на уровне государства).

В последние годы муниципалитеты Лапландии испытывают определенные трудности в области формирования доходной базы. Об этом, в частности, свидетельствует дефицитность бюджетов в 2016 г. восьми из двадцати одной общины Лапландии. При этом в структуре доходов коммун самого северного региона Финляндии существенна доля государственных средств (на 1 евро налоговых доходов, получаемых коммунами, приходится в среднем 0,65 евро государственных средств). В 2016 г. объем выделяемых государством средств на каждого жителя Лапландии составил 2491 евро (или примерно 2610 долл. США) [65].

Субсидии бюджетам коммун Лапландии предоставляются в основном на выравнивание бюджетной обеспеченности, а также на финансирование выполнения переданных государством коммунам функций. Размер выделяемых субсидий рассчитывается исходя из территориального расположения муниципалитета (чем севернее расположена коммуна, тем больше объем выделяемой субсидии), плотности населения, экономических показателей, численности слабозащищенных групп населения и других условий.

В связи с тем, что формула расчета субсидии достаточно сложна, ее размер в расчете на душу населения даже непосредственно внутри одного региона Лапландии существенно различается (в 2016 г. значения по коммунам различались более чем в 3 раза) (рис. 8 ).

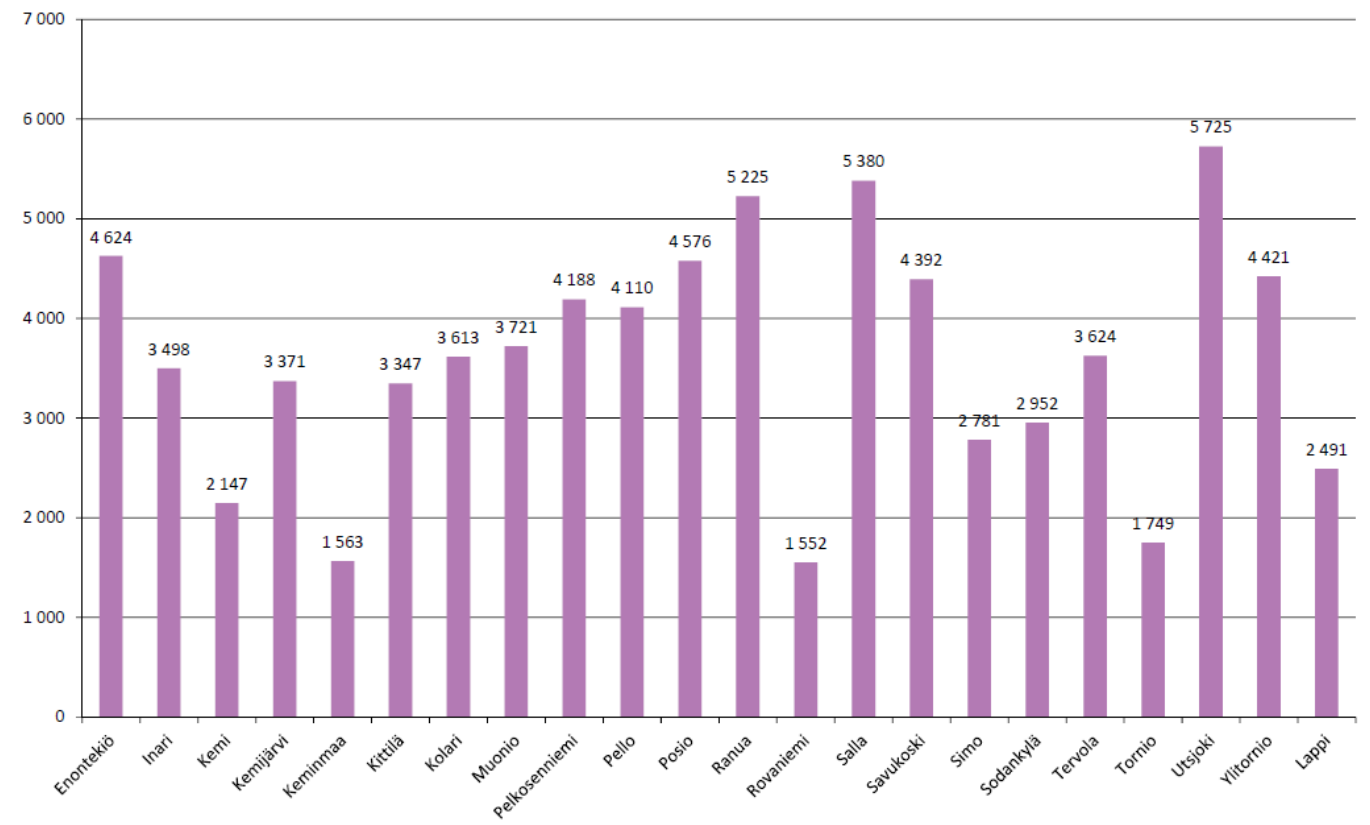

Рис. 8. Размер выделенных государственных средств на 1 жителя муниципалитетов Лапландии в 2016 г. (евро/чел.) [67] 
Муниципальные органы власти в Финляндии обладают достаточно широким объемом полномочий в области формирования местных налоговых систем.

В целом за последние годы в Финляндии при реализации регионального финансового регулирования акцент был смещен с процесса перераспределения создаваемого в масштабах страны дохода в сторону финансирования процессов реализации внутреннего экономического и финансового потенциала отдельных областей. Однако следует отметить, что, несмотря на положительную оценку опыта реализации региональной политики в Финляндии, в этой северной стране сохраняется значительная дифференциация в уровнях экономического развития отдельных территорий. Лапландия в настоящий момент является одним из менее привлекательных регионов для жизни населения, о чем свидетельствует сохраняющийся отток молодого населения в южные области.

Одной из самых эффективных систем регионального финансового регулирования в настоящий момент признана система, сложившаяся в Швеции.

Швеция - европейская страна, около 22 \% территории которой находится за Северным полярным кругом. Ее административное деление предполагает выделение 21 субъекта (лена). Самый северный лен - Норрботтен - расположен в арктической зоне. Население Норрботтена составляет примерно 250 тыс. человек, по плотности населения лен занимает последнее место среди регионов Швеции (плотность составляет около 2,5 чел. на 1 км²).

Экономика Норрботтена основана преимущественно на добыче полезных ископаемых (на территории находятся значительные залежи железной руды) и на лесной промышленности. В последнее время в регионе активно развиваются туристическая отрасль и сфера услуг, представленная большим количеством субъектов малого бизнеса. В последние годы Норрботтен является одним из лидеров среди ленов Швеции по производительности труда и объему инвестиций [66].

Следует отметить, что поддержка арктических территорий как отдельное направление регионального финансового регулирования в Швеции не предусмотрена. Финансовое выравнивание развития Норрботтена происходит в рамках общегосударственной системы регионального выравнивания.

До 1960-х гг. в Швеции не было упорядоченной системы регионального финансового регулирования, но при этом в стране применялись отдельные финансовые инструменты, такие как выделение субсидий коммунам и ландстингам ${ }^{7}$. Первая попытка создания целостной системы финансового выравнивания в Швеции была предпринята в 1966 г. Частичные преобразования система финансового регулирования претерпела в 1993 г. (в большей степени изменения коснулись финансовых инструментов, используемых для развития коммун, лены практически не были затронуты реформой).

Следующий этап реформирования системы регионального финансового регулирования пришелся на 1996 г. Реформа коснулась как коммун, так и ленов. Новая система подразумевала выплату субсидии, исходя из уровня доходов, расходов территории, общегосударственной субсидии и переходных регуляторов.

\footnotetext{
${ }^{7}$ Наименование административно-территориального органа власти в Швеции.
} 
Современная система регионального финансового регулирования Швеции была введена в 2005 г. и состоит из пяти компонентов: выравнивание доходов и расходов, структурная, переходная и корректирующая субсидии [67].

Выравнивание доходов осуществляется исходя из пограничного значения в $115 \%$ от среднего объема доходов по коммунам и $110 \%$ от среднего объема доходов по ленам. Коммуны и лены, имеющие меньшие значения доходов, получают субсидии. Для прочих коммун и ленов устанавливается взнос.

Выравнивание по расходам осуществляется с опорой на специфику конкретной коммуны или лена и связано с половозрастной структурой населения, особенностью хозяйства территории. Тем субъектам, которым в соответствии с их спецификой требуются более высокие бюджетные затраты, выделяются субсидии. Для субъектов со стандартной системой хозяйства устанавливается взнос. Норрботтен является ярко выраженным реципиентом по данному виду финансовых субсидий.

Структурные субсидии выделяют тем территориям, которые до реформы 2005 г. имели дополнительные перечисления, но с учетом внесенных изменений их потеряли.

Переходная субсидия была временной, действовала до 2010 г. и была предназначена для сглаживания негативных эффектов введения новой системы финансового регулирования и постепенной адаптации к ней коммун и ленов.

Корректирующие субсидии в настоящий момент выделяются тем территориям, которым правительство передает выполнение дополнительных функций и решение новых задач.

В 2016 г. объем выделенных государственных средств на одного жителя Норрботтена составил 11014,5 шведских крон (или чуть более 1220 долл. США). При этом около $65 \%$ от объема государственных субсидий приходится на перечисления коммунам, а 35 \% непосредственно лену Норрботтен ${ }^{8}$. Следует отметить, что современная система расчета субсидий для каждого муниципалитета позволяет достаточно широко дифференцировать размер государственных субсидий в соответствии с условиями, сложившимися в отдельных муниципалитетах. Это подтверждают данные рис. 9.

Даже среди отдельных коммун Норрботтена размер государственных перечислений в расчете на одного жителя в 2016 г. различался более чем в 10 раз. В структуре государственных перечислений северным коммунам в настоящий момент преобладают такие элементы, как субсидии по выравниванию доходов и структурные субсидии.

По сравнению с арктическими муниципалитетами других стран размер государственной помощи коммунам в Швеции достаточно невысок. Это объясняется в первую очередь небольшими различиями в уровнях экономического развития самого северного лена и других территорий данной страны. Развитое хозяйство и рациональная система местного налогообложения позволяет формировать коммунам Норрботтена высокий уровень собственных доходов, необходимых для их развития. Дополнительно для повышения инвестиционного потенциала территорий Норрботтена субъектам хозяйствования, работающим в этом регионе, предоставляются различные субсидии и льготы по налогам.

Использование эффективной системы финансового регулирования территориального развития позволило Швеции добиться существенного

\footnotetext{
${ }^{8}$ Данные по разделу «Финансы» Статистического управления Швеции [68].
} 
снижения региональной дифференциации, а также высокого уровня жизни населения на всей территории проживания.

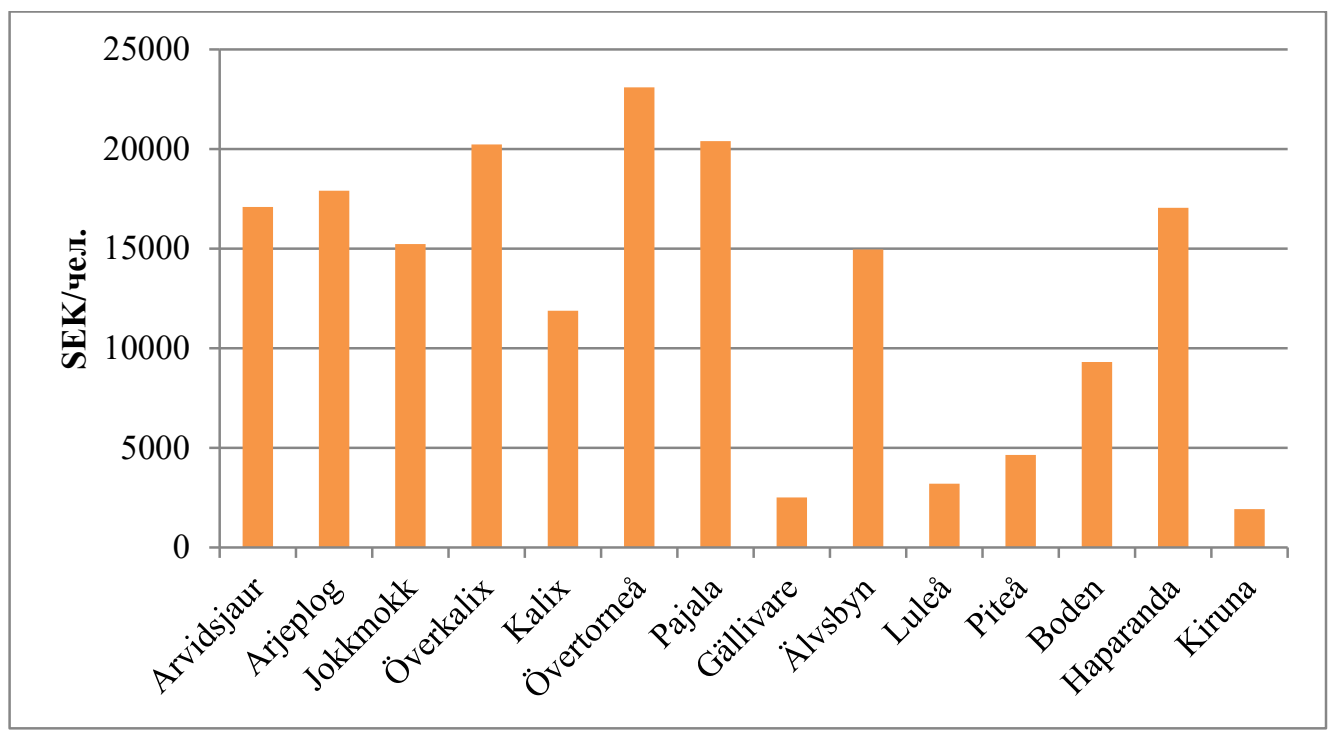

Рис. 9. Выделение государственных средств муниципалитетам Норрботтена в 2016 г.

Одной из стран со значительной долей арктических территорий является Норвегия. Система административного устройства в данной стране включает 19 губерний (округов или фюльке), которые разделены на коммуны (муниципалитеты). Традиционно к арктическим губерниям Норвегии относят три округа Финнмарк, Тромс, Нурланн - с общей площадью 113 тыс. км ${ }^{2}$ и населением около 475 тыс. чел. Также к арктическим территориям Норвегии относится арх. Шпицберген, его площадь - 61 тыс. км ${ }^{2}$, население - около 2,5 тыс. чел. Следует отметить, что Шпицберген не является полноценной губернией Норвегии, а наделен статусом так называемой заморской территории, в связи с чем архипелаг не имеет традиционного для данной страны деления на коммуны.

Арктические округа Норвегии специализируются на рыбной промышленности, оленеводстве, туризме (последний особенно развит в губерниях Нурланн и Тромс). Значительная часть населения северных территорий Норвегии занята в нефтедобыче на шельфе Баренцева моря. Из полезных ископаемых здесь представлены вольфрам, пирит и известняк.

В настоящий момент основы регионального финансового регулирования северных территорий в Норвегии заложены в Государственной стратегии реализации политики устойчивого развития северных регионов страны на 20112030 гг. [69].

Норвегия, наряду со Швецией, Данией, Финляндией, относится к группе стран с высокой долей участия субнациональных властей в финансировании социальных расходов [70]. Координацию политики в области развития Крайнего Севера и Арктики осуществляет Министерство иностранных дел Норвегии через формирование соответствующего бюджетного послания.

Финансовое регулирование развития арктических территорий Норвегии осуществляется на трех уровнях: первый уровень — дотации из государственного 
бюджета губерниям и коммунам; второй - установленная система льгот, прежде всего налоговых, субъектам хозяйствования, осуществляющим деятельность в северных округах; третий уровень включает дополнительную поддержку населению, проживающему на арктических территориях.

В качестве граничного показателя, влияющего на выделение региону дотаций или установление для него дополнительных взносов, используется показатель налоговых поступлений на одного жителя соответствующего субъекта, при этом в качестве критериального показателя используется значение в $110 \%$ от среднего уровня налоговых поступлений, что позволяет получать дополнительные дотации примерно 90 \% коммун Норвегии. И лишь для примерно $4 \%$ коммун установлены взносы с излишних доходов (при превышении граничного значения в $134 \%$ от средних налоговых поступлений). Коммуны, располагающиеся в округах Финнмарк, Тромс, Нурланн, практически в полном составе относятся к дотационным. В целом дотации составляют от 30 до $50 \%$ от общей доходной базы бюджетов территорий в Норвегии.

В северных фюльке Норвегии в 2016 г. объем государственных дотаций в форме грантов бюджетам коммун в расчете на одного жителя в среднем составил порядка 3,7 тыс. долл. США (рис. 10), что выше, чем в арктических регионах соседних Финляндии и Швеции. При этом стоит подчеркнуть, что размер грантов в пересчете на человека в северных фюльке Норвегии в целом сопоставим с аналогичным показателем по стране. Учитывая комплексный характер расчета размера государственных грантов коммунам в Норвегии, можем говорить об отсутствии существенной разницы в уровнях социальноэкономических показателей северных коммун и коммун, расположенных в других регионах страны.

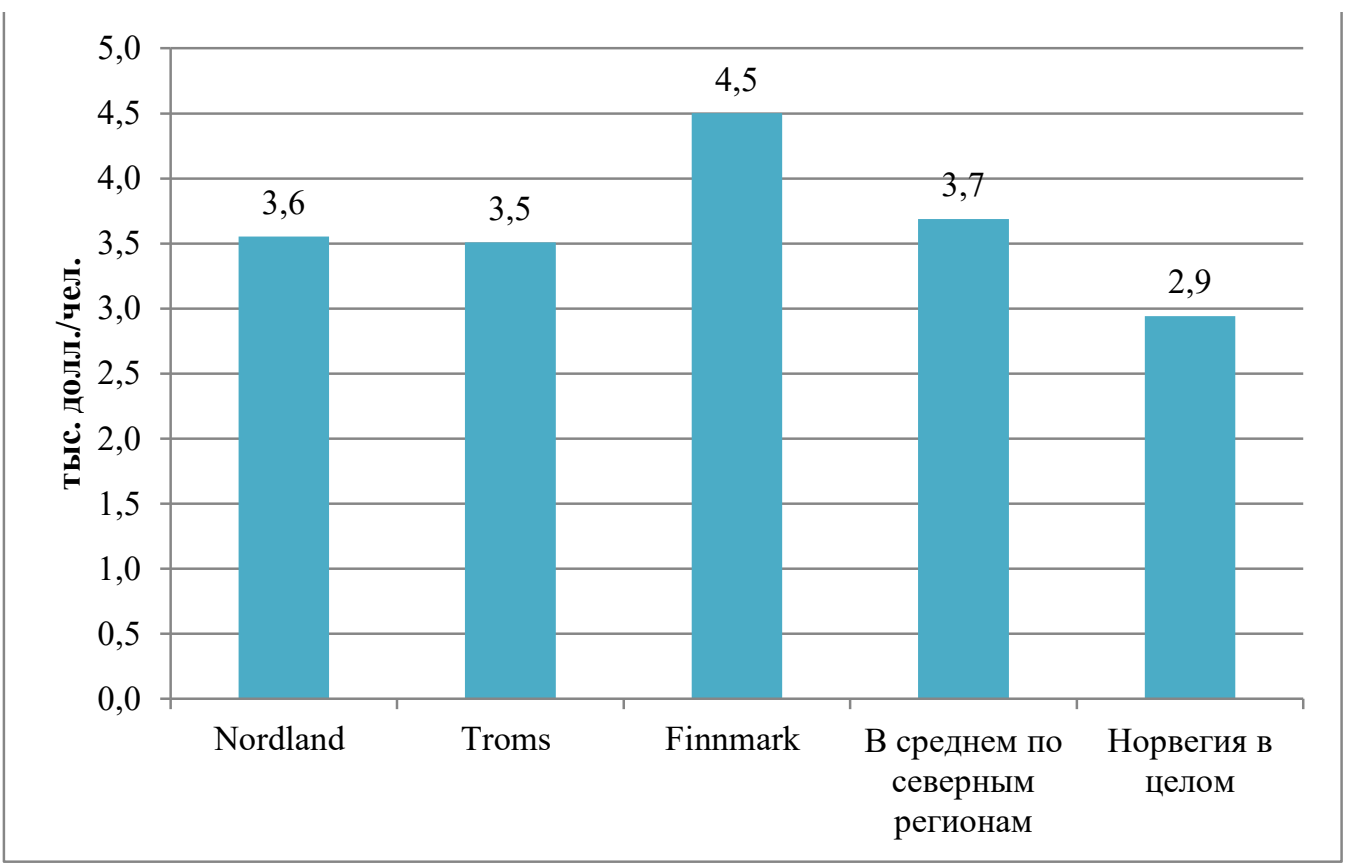

Рис. 10. Объем государственных грантов в расчете на одного жителя коммуны по северным фюльке Норвегии в 2016 г. (тыс. долл/чел.) [71] 
В округах, относящихся к арктическим территориям Норвегии (фюльке Финнмарк и семь муниципалитетов в фюльке Тромс), установлены существенные налоговые льготы и специальные программы для хозяйствующих субъектов и населения. Для бизнеса установлены нулевые взносы в Фонд социального страхования и низкий налог на потребление электроэнергии (для организаций, работающих в сфере оказания бытовых услуг и в общественном секторе, налог за электроэнергию отсутствует полностью). Реализуется программа развития технологий и инноваций, направленная на поддержку инновационных компаний и проектов в Северной Норвегии. Для населения, проживающего на территории самых северных коммун, установлены более низкие ставки подоходного налога. Для студентов, которые живут в Северном Тромсе и Финнмарке, предусмотрены льготы при получении и погашении образовательных кредитов. До недавнего времени в данных муниципалитетах выплачивалось семейное пособие 320 норвежских крон в месяц на семью или 3840 крон на каждого ребенка в год (отменено в 2014 г.), а также субсидии для педагогов дошкольных учреждений (отменены в 2012 г.). Общая стоимость дополнительных льгот, установленных на Севере Норвегии, оценивается в сумму около 2 млрд норвежских крон в год [72].

Финансовое регулирование развития территорий Крайнего Севера и Арктики в Норвегии является одним из наиболее передовых и результативных, что позволило стране существенно сократить отток населения с этих территорий и значительно повысить уровень жизни.

Исландия - самая маленькая по численности арктическая страна, в ней проживает около 330 тыс. чел. Несмотря на то, что в этой унитарной стране имеется определенное административно-территориальное деление (территория делится на сисла и городские округа, в общей сложности которых восемь), говорить о наличии в данной стране особой финансовой политики по отношению к северным и арктическим зонам нельзя. И хотя по территории Исландии проходит Северный полярный круг, по своим природно-климатическим условиям она далека от других арктических стран.

Обобщим проведенный анализ по изучению опыта реализации регионального финансового регулирования в отношении территорий Крайнего Севера и Арктики за рубежом (табл. 8).

Отличительной особенностью финансового регулирования развития арктических территорий за рубежом является применение методов, в большей степени соответствующих не регулированию, а координации, предполагающей взаимовыгодное партнерство с субъектами хозяйствования на них. Страны стремятся не просто обеспечить достаточный уровень расходов на этих территориях, но и создать условия для реализации их внутреннего потенциала и повышения их привлекательности для потенциальных инвесторов, предприятий и населения.

Следует отметить, что в силу объективных и субъективных причин территории Крайнего Севера и Арктики характеризуются более низкими показателями социально-экономического развития, формирования ВРП, обеспеченности населения услугами. Но при этом в некоторых странах такие различия проявляются в большей степени (Канада, Финляндия, США, Дания), в других — в меньшей степени (Норвегия, Швеция). 
Характеристики регионального финансового регулирования в арктических странах

\begin{tabular}{|l|c|c|c|c|c|c|}
\hline \multicolumn{1}{|c|}{ Показатели } & Канада & США & Норвегия & Финляндия & Швеция & Дания \\
\hline $\begin{array}{l}\text { Наличие региональной финансовой политики } \\
\text { по отношению к северным и арктическим территориям }\end{array}$ & ++ & ++ & + & ++ & + & ++ \\
\hline $\begin{array}{l}\text { Дифференциация уровня экономического развития } \\
\text { северных и арктических и прочих субъектов }\end{array}$ & ++ & ++ & + & ++ & + & ++ \\
\hline $\begin{array}{l}\text { Степень финансовой самостоятельности северных } \\
\text { и арктических территорий }\end{array}$ & +++ & ++ & + & + & + & ++ \\
\hline $\begin{array}{l}\text { Использование прямых инструментов } \\
\text { для развития северных и арктических территорий } \\
\text { (программно-целевые инструменты и система } \\
\text { межбюджетных трансфертов) }\end{array}$ & +++ & ++ & ++ & ++ & ++ & ++ \\
\hline $\begin{array}{l}\text { Использование косвенных финансовых рычагов } \\
\text { развития северных и арктических территорий } \\
\text { (налоговые, дополнительные льготы, специальные } \\
\text { фонды и т.д.) }\end{array}$ & ++ & ++ & ++ & ++ & ++ & ++ \\
\hline
\end{tabular}

Примечания:

«-» - характеристика отсутствует.

«+» - характеристика слабо выражена.

«++» - характеристика выражена умеренно.

«+++» - характеристика сильно выражена. 
Арктические территории различаются по степени финансовой самостоятельности, которой наделены региональные и муниципальные органы власти на них. На одних территориях региональные власти обладают широкими полномочиями в области налоговой, бюджетной, кредитной политики (провинции в Канаде, Гренландия, Аляска), на других субъекты самоуправления действуют на общих основаниях и не имеют дополнительных полномочий по сравнению с другими регионами (Финляндия, Швеция, Норвегия).

В качестве финансовых инструментов развития северных территорий используются как прямые рычаги - программно-целевые инструменты и системы финансового выравнивания на основе межбюджетных трансфертов (Финляндия, Канада, Швеция, Норвегия), так и косвенные - формирование привлекательных условий для субъектов хозяйствования на основе льготных систем налогообложения, субсидирования процентных ставок, формирования выплат населению из специализированных фондов (США, Дания).

\section{2. Государственное регулирование социально-экономического развития северных территорий в России: история и современность}

Несомненно, что научные разработки и опыт практического развития экономики северных регионов зарубежных стран будут очень полезными для России, основная часть территории которой считается зоной Севера. На современном этапе именно северные регионы за счет своей богатейшей природно-минеральной базы стали основным источником ресурсов нашей страны.

На сегодняшний день в списке районов Крайнего Севера числится пять областей (Архангельская, Мурманская, Магаданская, Иркутская, Сахалинская), три края (Хабаровский, Красноярский, Камчатский), четыре республики (Тыва, Коми, Карелия, Саха (Якутия)), четыре автономных округа (Ханты-Мансийский, Ямало-Ненецкий, Чукотский и Ненецкий). Этот перечень дополняют и острова, расположенные в Северном Ледовитом океане, Беринговом и Охотском морях, где живут и работают люди.

Современные территории Крайнего Севера и Арктики присоединялись к России поэтапно, на протяжении достаточно продолжительного времени (табл. 9). Европейская часть северных земель (современная территория Карелии Архангельской обл., юг Мурманской обл.) входили в состав Новгородского княжества еще в период феодальной раздробленности в XII-XIII вв. В состав же Великого Московского княжества эти территории вошли в период «собирания земель» при правлении Ивана III Великого во второй половине XV в. В это же время к Руси были присоединены территории современной Республики Коми и частично Ханты-Мансийского автономного округа.

Следующий важный этап присоединения северных территорий к Русскому государству - вторая половина XVI в., когда было завоевано Сибирское ханство. В 1581-1585 гг. Великое Московское царство во главе с Иваном Грозным значительно расширило свои границы за счет присоединения Западной Сибири (в том числе современных территорий Ямало-Ненецкого и Ханты-Мансийского автономных округов). Дальнейшее покорение Сибири и Дальнего Востока длилось вплоть до начала XX в. и проходило на фоне ожесточенных боев с местным населением, основания новых крупных городов и значимых географических открытий. 
Таблища 9

Северные территории, присоединенные к Великому Московскому княжеству и Великому Владимирскому княжеству, до их объединения

\begin{tabular}{|c|c|c|}
\hline $\begin{array}{c}\text { Территория } \\
\text { и год присоединения }\end{array}$ & $\begin{array}{c}\text { Особенности статуса } \\
\text { территории и присоединения }\end{array}$ & $\begin{array}{c}\text { Современный статус } \\
\text { территории } \\
\end{array}$ \\
\hline $\begin{array}{l}\text { Южная часть Коми } \\
\text { (1397) }\end{array}$ & $\begin{array}{l}\text { Присоединены от Новгорода } \\
\text { военной силой. Окончательно } \\
\text { закреплены в } 1462 \text { г. }\end{array}$ & $\begin{array}{l}\text { Вологодская обл., } \\
\text { Республика Коми }\end{array}$ \\
\hline $\begin{array}{l}\text { Пермь Вычегодская } \\
\text { (1451) }\end{array}$ & $\begin{array}{l}\text { Первые русские поселения } \\
\text { вошли в состав в начале XV в., } \\
\text { окончательное присоединение } \\
\text { в } 1451 \text { г. }\end{array}$ & $\begin{array}{l}\text { Пермский край, } \\
\text { Республика Коми }\end{array}$ \\
\hline $\begin{array}{l}\text { Важская земля } \\
\text { (1471) }\end{array}$ & $\begin{array}{l}\text { В XIV-XV вв. Новгородско- } \\
\text { Ростовское совладение. } \\
\text { Были захвачены }\end{array}$ & $\begin{array}{l}\text { Вологодская обл., } \\
\text { Архангельская обл. }\end{array}$ \\
\hline $\begin{array}{l}\text { Олонец, Великие Луки, } \\
\text { Карелия, Подвинье, } \\
\text { Кола, Заволочье и др. } \\
\text { (1478) }\end{array}$ & $\begin{array}{l}\text { С } 1456 \text { г. московско- } \\
\text { новгородские войны, } \\
\text { постепенная ликвидация } \\
\text { автономии }\end{array}$ & $\begin{array}{l}\text { Архангельская обл., } \\
\text { Мурманская обл., } \\
\text { Республика Карелия, } \\
\text { Республика Коми }\end{array}$ \\
\hline $\begin{array}{l}\text { Югорская земля } \\
(1483-1499)\end{array}$ & $\begin{array}{l}\text { Вассалитет, автономия } \\
\text { в 1478-1483 гг., окончательно } \\
\text { присоединены к } 1582 \text { г. }\end{array}$ & $\begin{array}{l}\text { Республика Коми, } \\
\text { Ханты-Мансийский } \\
\text { автономный округ }\end{array}$ \\
\hline
\end{tabular}

Отдельно следует упомянуть об Аляске, освоение которой началось в 1741 г. во время правления Елизаветы Петровны и которая более 120 лет являлась российской территорией, пока не была продана США в 1867 г. при правлении Александра II, а также о территории Курильских островов, споры, о принадлежности которых между Россией и Японией ведутся до сих пор.

Если на протяжении многих столетий Российское государство придерживалось активной политики по присоединению континентальных северных территорий, то свое внимание на водные арктические пространства и острова Северного Ледовитого океана как на собственные земли государственные деятели обратили сравнительно недавно. О своих притязаниях на водные территории, прилагающие с севера к материку, российское государство заявило в Ноте Министерства иностранных дел 20 сентября 1916 г. Это стало ответом на рост интереса к арктическим пространствам других северных стран, прежде всего Канады и Дании.

О перспективности изучения арктических пространств высказывались видные российские ученые и ранее, в частности М. В. Ломоносов писал о значительных природных богатствах, находящихся в Арктике, и о необходимости проведения полноценных экспедиционных исследований этих территорий [73], а морские экспедиции в воды Северного Ледовитого океана, направленные на изучение возможностей Северного морского пути, проводились на регулярной основе (см., например: [74]).

Как самостоятельное звено общей системы государственного регулирования территориального развития политика регулирования развития северных территорий в нашей стране имеет незначительную историю. Различные 
инструменты и механизмы финансового обеспечения развития данных территорий стали активно применяться лишь в последние несколько столетий нашей истории.

До XVIII в. территории Крайнего Севера рассматривались как источник природных богатств пушных и морских промыслов. Основной целью организации экспедиций в эти края и присоединения северных территорий было не только прирастание новыми землями и защита от набегов восточных ханств, но и установление ясака - налога, которым обкладывалось местное население и который платился в пересчете на единицу пушнины. Большие неосвоенные территории и слабовооруженное местное население позволяли привозить из походов, направляемых на север и восток, подати значительных размеров. По некоторым оценкам, поступления от взимания ясака составляли в то время до $30 \%$ всех государственных доходов [75].

В XVIII-XIX вв. политика в отношении северо-восточных земель в российском государстве претерпевает значительные изменения. На первый план выходят геополитические интересы страны в этом регионе. В этом период осуществляются значимые экспедиционные проекты (экспедиции Ф. П. Врангеля, П. П. Крузенштерна, В. Я. Чичагова и др.), развиваются уезды и остроги, начинают реализовываться крупные транспортные проекты в Сибири, изучается возможность использовать потенциал Северного морского пути. Все эти проекты требовали значительных финансовых ресурсов, которые выделялись как из государственной казны, так и за счет привлечения средств тех, кого в настоящее время называют инвесторами.

Интересен опыт создания на рубеже XVIII-XIX вв. закрытого акционерного общества «Российско-Американская компания», которая представляла собой масштабный проект, основанный на принципах государственно-частного партнерства, созданный для ведения промышленной деятельности на Севере, в Сибири и Дальнем Востоке (пушной и морской промысел), ведения торговой деятельности, позднее - организации доставки из стран Центральной и Восточной Азии товаров и продукции в столичные города Российского государства. Для создания компании был выделен государственный кредит в размере 150 тыс. руб. и сформирован уставный капитал в размере более 2,5 млн руб. На протяжении первой половины XIX в. компания приносила значительные доходы в казну, вела работу по развитию и поддержке социальной сферы поселений в восточной части России, а также способствовала ведению экспедиционной и картографической работы на северо-восточных окраинах страны ${ }^{9}$. Компания просушествовала до 1867 г., когда было принято решение о ее закрытии и продаже территории Русской Америки (Аляски) США.

Одним из финансовых рычагов, который пыталось использовать государство для активизации морской торговли с северными сибирскими городами, стали льготы, предполагающие беспошлинный ввоз (или по сниженным таможенным ставкам) большого спектра заграничной продукции. Во второй половине XIX в. Министерством финансов был установлен широкий перечень товаров (среди которых керосин, инструменты, машины, оборудование, бакалейные товары и многое другое), которые иноземные купцы могли беспошлинно завозить в населенные пункты Сибири, используя Северный

\footnotetext{
${ }^{9}$ Более подробно о деятельности Российско-Американской компании см.: [74].
} 
морской путь и маршруты крупных сибирских рек (Обь, Енисей, Лена и др.). Установленные льготы неоднократно продлялись и просуществовали вплоть до Октябрьской революции 1917 г.

Активную поддержку развитию торговли на Севере российского государства оказывала организация ярмарок, где велись масштабные обменные операции с иноземными торговцами. Наиболее известными и крупными ярмарками в конце XVIII - начале XX вв. были Якутская, Березовская, Сургутская и Обдорская ${ }^{10}$. Росту объемов торгового оборота способствовала также организация кредитной системы, когда местные промысловики получали от торговцев продукты питания, орудия, необходимые снасти, а в счет погашения долгов сдавали добытое в течение года.

Советское государство на протяжении всей своей истории считало северные и арктические территории зоной стратегических интересов, рассматривая эти пространства как зону уникальных природных богатств, форпост обороны страны, значимую транспортную артерию (Северный морской путь одно время считался кратчайшим маршрутом, способным обеспечить значительные грузопотоки между самыми западными и самыми восточными точками страны).

Советский этап - период наиболее активного освоения Севера в нашей стране. Наличие жестких планов, возможность мобилизовать значительные трудовые усилия, необходимость поиска ресурсов для реализации ударных темпов развития страны сформировали благоприятную среду для роста интереса к освоению слабо исследованных северных и восточных районов.

Освоение территорий Крайнего Севера и Арктики с первых лет образования Советского государства рассматривалось как определяющее условие обеспечения процесса индустриализации страны. В связи с этим в структуре государственных органов власти с 1920-х гг. создавались органы, в задачи которых входило промышленного развитие арктических пространств, организация судоходства по Северному морскому пути, экономическое развитие северных регионов:

- Комитет содействия развитию окраин Сибири и населяющих их малых народностей Севера при Президиуме ВЦИК (1924);

- Комиссия для организационной и финансовой проработки пятилетнего плана научно-исследовательской работы в арктических владениях Союза ССР при Совете народных комиссаров Союза ССР (1928);

- Главное управление Северного морского пути при Совете народных комиссаров Союза ССР (Главсевморпуть) и Всесоюзный арктический институт при ЦИК СССР (1933).

В ключевых центральных кооперативных органах («Центросоюз», «Всекоохотсоюз», «Интегралсоюз») были созданы группы по развитию северных территорий.

Уже в первые послереволюционные годы, несмотря на сложное политическую ситуацию и разрушенную экономику, советские органы власти находят возможность отправить во многие северные районы (Печорский, Обский, Охотское побережье, Камчатку, Колыму) значительные продовольственные

\footnotetext{
${ }^{10}$ Более подробно о работе этих ярмарок см.: [74].
} 
запасы, охотничьи и рыболовные снасти, строительные материалы, что помогло избежать во многих северных регионах массового голода и полного хозяйственного упадка.

В начале 1930-х гг. Государственный плановый комитет Совета министров СССР (государственный орган, осуществляющий планирование развития народного хозяйства в СССР и контроль за реализацией планов) подготовил концепцию социалистического освоения Севера (основные положения концепции изложены в [76]), ставшую основой отдельного раздела (раздел «Освоение Советской Арктики») во втором пятилетнем плане развития народного хозяйства СССР (1933-1937). В частности, план второй пятилетки предполагал: освоение Печорского угольного бассейна, Хибинских месторождений (апатитонефелиновые руды) на Кольском п-ове, месторождений золота в Сибири, развитие лесной промышленности, возведение горнометаллургического комплекса в Восточно-Сибирском крае (нынешний Красноярский край), развитие Северного морского пути, строительство железных дорог и многое другое. Большинство из этих проектов, несмотря на то, что для их воплощения необходимы значительные финансовые и трудовые ресурсы, были выполнены. Это удалось сделать за счет труда заключенных и репрессированных, которые активно привлекались к реализации крупных проектов и необходимой для привлечения дополнительных трудовых ресурсов инфраструктуры.

Новый виток интереса к освоению Севера в СССР начался после окончания Великой Отечественной войны, что было связано с необходимостью разведки и реализации проектов по промышленной добыче углеводородов, которые должны были стать основой энергетического обеспечения развития хозяйства страны. Итогом работы по данному направлению стало создание на севере Западной Сибири одного из крупнейших не только в нашей стране, но и мире комплекса по добычи нефтегазовых ресурсов.

С 1960-х гг. наблюдается существенное увеличение инвестиций в развитие хозяйства северных регионов. Только в 1961-1965 гг. в экономику северных территорий было вложено примерно столько же, сколько инвестировано за предыдущие годы существования советской власти (до 1960-х гг. общий объем инвестиций в северные районы составил около 14 млрд руб.) [77], а за период с 1960 по 1980 гг. общий аналогичный объем инвестиций превысил 100 млрд руб. [78]. Следует отметить, что если в дореволюционный этап освоения Севера в основном был задействован частный российский капитал и капитал иностранных компаний, которые вели торговую деятельность на этих территориях (прежде всего, на Европейском Севере и Дальнем Востоке), то в период СССР преобладал плановый характер развития страны, а на исполнение крупных промышленных и инфраструктурных проектов привлекалось государственное финансирование.

В 1960-1970-х гг. одним из важных шагов на пути развития промышленного потенциала северных территорий стала разработка и принятие Генеральной схемы развития и размещения производительных сил в СССР (первый документ был разработан на период 1966-1970 гг., в дальнейшем принимались документы на 1971-1980 гг., 1976-1990 гг., а также на периоды до 2000 г., 2005 г. и 2010 г.). В содержании этих документов отчетливо просматривалась тенденция смещения основных производительных сил на север и восток. Важность принятых генеральных схем развития и размещения производительных сил заключалась в том, что они служили основой 
для составления и принятия основных направлений экономического и социального развития СССР на различные периоды $(5,10$ и 15 лет) и пятилетних планов. Основным инструментом индустриального освоения Севера становились территориально-производственные комплексы (ТПК) - совокупность экономически, технологически и инфраструктурно связанных между собой предприятий (аналоги современных производственных кластеров). Наиболее крупными ТПК стали: нефтегазовые комплексы в Тимано-Печорском бассейне, на севере Западной Сибири, горно-металлургический комплекс в Красноярском крае, горнодобывающий комплекс в Мурманской обл. На возведение новых промышленных объектов, строительство транспортных артерий и узлов в 1960 1980-е гг. были выделены колоссальные ресурсы. При этом важно отметить, что развитию социальной сферы на Севере государство уделяло гораздо меньше внимания. Декларируя принципы комплексного социально-экономического развития в планах и стратегических документах, на практике приоритет отдавался строительству производственных объектов, которые были способны обеспечить заданные темпы экономического роста, реализация социальной составляющей комплексного развития оставлялась на будущее.

Кроме прямых инвестиций в реализацию крупных проектов на северных территориях применялись и другие рычаги развития. Так, в отдаленных областях на протяжении всего периода их освоения наблюдался недостаток трудовых ресурсов и квалифицированных кадров. Для решения этой проблемы с 1930-х гг. в СССР активно развивается законодательство о льготах проживающим и трудящимся в местностях с суровыми климатическими условиями.

Первым документом, регулирующим привлечение рабочей силы на северные территории, стало постановление от 12.08.1930 Центрального исполнительного комитета СССР № 42, Совета народных комиссаров СССР № 204a [79], которым устанавливались надбавки к заработной плате работников, трудящихся в отдаленных местностях Союза ССР и вне крупных городских поселений (10 \%-я надбавка по истечении каждых трех лет работы, но не более $100 \%$ от размера оклада работника), размеры дополнительного отпуска для таких работников, а также льготы по обучению детей, жилищные, налоговые льготы и дополнительное снабжение предметами потребления.

Непосредственно льготы для трудящихся на территории Крайнего Севера были установлены спустя несколько лет постановлением ВЦИК и СНК РСФСР от 10.05.1932 [80], а сами территории, на которые распространяется действие данного постановления, были определены в постановлении СНК РСФСР от 26.10.1932 [81]. Впоследствии спектр льгот и их размеры неоднократно пересматривались, а в некоторые периоды их действие прекращалось (например, действие норм о льготах трудящимся в районах Крайнего Севера было прервано на время Великой Отечественной войны).

Необходимо отметить, что сам перечень регионов, которые относились к территориям Крайнего Севера в СССР, также не являлся неизменным. За годы существования советской власти наблюдалась тенденция к постепенному расширению нормативно установленных северных территорий. Одним из наиболее системных и близких к современному положению документов, определяющих перечень районов Крайнего Севера и местностей, приравненных к районам Крайнего Севера, стало постановление Совета министров СССР от 10.11.1967 № 1029 (табл. 10). 
Районы Крайнего Севера в соответствии с постановлением Совмина СССР от 10.11.1967 № 1029 (с изменениями, принятыми последующими документами)

\begin{tabular}{|c|c|c|c|}
\hline $\begin{array}{l}\text { № } \\
\text { П/ா }\end{array}$ & Район & Последующие изменения & $\begin{array}{l}\text { Основание } \\
\text { изменений }\end{array}$ \\
\hline 1 & $\begin{array}{l}\text { Все острова Северного } \\
\text { Ледовитого океана и его морей, } \\
\text { а также острова Берингова } \\
\text { и Охотского морей }\end{array}$ & - & - \\
\hline 2 & $\begin{array}{l}\text { Мурманская обл., } \\
\text { за исключением г. Кандалакша } \\
\text { с территорией, находящейся } \\
\text { в административном } \\
\text { подчинении Кандалакшского } \\
\text { городского Совета народных } \\
\text { депутатов }\end{array}$ & $\begin{array}{l}\text { С } 1 \text { июля } 1990 \text { г. вся область, } \\
\text { включая г. Кандалакша } \\
\text { с территорией, находящейся } \\
\text { в административном } \\
\text { подчинении Кандалакшского } \\
\text { городского Совета народных } \\
\text { депутатов }\end{array}$ & $\begin{array}{l}\text { Постановление } \\
\text { Совмина СССР } \\
\text { от } 23.06 .1990 \\
\text { № } 594\end{array}$ \\
\hline 3 & $\begin{array}{l}\text { Архангельская обл. —- } \\
\text { Ненецкий автономный округ } \\
\text { и г. Северодвинск } \\
\text { с территорией, находящейся } \\
\text { в административном } \\
\text { подчинении Северодвинского } \\
\text { городского Совета народных } \\
\text { депутатов; районы: Онежский, } \\
\text { Лешуконский, Мезенский, } \\
\text { Пинежский, Плесецкий, } \\
\text { Приморский, Холмогорский; } \\
\text { города: Онега, Архангельск, } \\
\text { Новодвинск }\end{array}$ & 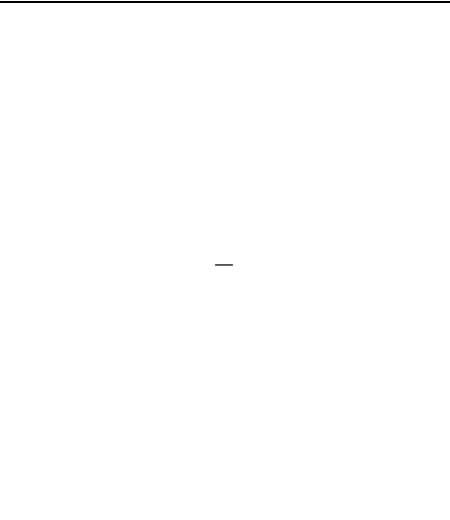 & - \\
\hline 4 & $\begin{array}{l}\text { Коми АССР- } \\
\text { города Воркута и Инта } \\
\text { с территориями, находящимися } \\
\text { в административном } \\
\text { подчинении их городских } \\
\text { Советов народных депутатов, } \\
\text { и Усинский район, } \\
\text { за исключением Усть- } \\
\text { Лыжинского сельсовета } \\
\end{array}$ & $\begin{array}{l}\text { С } 1 \text { апреля } 1992 \text { г. Ижемский, } \\
\text { Усть-Цилемский, Печорский } \\
\text { районы; } \\
\text { с } 1 \text { января } 2008 \text { г. город } \\
\text { республиканского значения } \\
\text { Печора и село Усть-Лыжа } \\
\text { с подчиненной ему } \\
\text { территорией (Республика } \\
\text { Коми) }\end{array}$ & $\begin{array}{l}\text { Указ Президента } \\
\text { РФ от 24.01.1992 } \\
\text { № 46; } \\
\text { постановление } \\
\text { Правительства РФ } \\
\text { от } 24.04 .2007 \\
\text { № } 245\end{array}$ \\
\hline 5 & $\begin{array}{l}\text { Тюменская обл. — Ямало- } \\
\text { Ненецкий автономный округ }\end{array}$ & 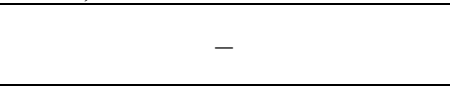 & - \\
\hline 6 & $\begin{array}{l}\text { Красноярский край - } \\
\text { Таймырский (Долгано- } \\
\text { Ненецкий) и Эвенкийский } \\
\text { автономные округа; города } \\
\text { Игарка и Норильск } \\
\text { с территориями, находящимися } \\
\text { в административном } \\
\text { подчинении их городских } \\
\text { Советов народных депутатов; } \\
\text { Северо-Енисейский } \\
\text { и Туруханский районы }\end{array}$ & $\begin{array}{l}\text { С } 1 \text { января } 2007 \text { г. в составе РФ } \\
\text { образован новый субъект - } \\
\text { Красноярский край, } \\
\text { возникший в результате } \\
\text { объединения трех граничащих } \\
\text { между собой субъектов } \\
\text { Федерации: Красноярского } \\
\text { края, Таймырского (Долгано- } \\
\text { Ненецкого) автономного } \\
\text { округа и Эвенкийского } \\
\text { автономного округа }\end{array}$ & $\begin{array}{l}\text { Ч. } 1 \text { ст. } 1 \\
\text { Федерального } \\
\text { конституционного } \\
\text { закона } \\
\text { от } 14.10 .2005 \\
\text { № 6-ФК3 }\end{array}$ \\
\hline
\end{tabular}


Окончание таблищы 10

\begin{tabular}{|c|c|c|c|}
\hline $\begin{array}{l}\text { № } \\
\Pi / \Pi\end{array}$ & Район & Последующие изменения & $\begin{array}{l}\text { Основание } \\
\text { изменений }\end{array}$ \\
\hline 7 & $\begin{array}{l}\text { Иркутская обл. - } \\
\text { Катангский район }\end{array}$ & - & - \\
\hline 8 & Якутская АССР & - & - \\
\hline 9 & Магаданская обл. & $\begin{array}{l}\text { Чукотский АО, являющийся } \\
\text { самостоятельным субъектом } \\
\text { РФ, также относится } \\
\text { к районам Крайнего Севера. } \\
\text { Ранее входил в состав } \\
\text { Магаданской обл. }\end{array}$ & $\begin{array}{l}\text { Ч. } 1 \text { ст. } 1 \\
\text { Федерального } \\
\text { конституционного } \\
\text { закона } \\
\text { от } 12.07 .2006 \\
\text { № 2-ФК3 }\end{array}$ \\
\hline 10 & Камчатская обл. & $\begin{array}{l}\text { С } 1 \text { июля } 2007 \text { г. в составе } \\
\text { РФ образован новый субъект } \\
\text { Федерации - Камчатский } \\
\text { край, возникший } \\
\text { в результате объединения } \\
\text { двух граничащих между } \\
\text { собой регионов - } \\
\text { Камчатской обл. } \\
\text { и Корякского автономного } \\
\text { округа }\end{array}$ & $\begin{array}{l}\text { Федеральный } \\
\text { конституционный } \\
\text { закон } \\
\text { от 12.07.2006 } \\
\text { № 2-ФК3 }\end{array}$ \\
\hline 11 & $\begin{array}{l}\text { Республика Карелия - } \\
\text { районы: Беломорский, } \\
\text { Калевальский, Кемский, } \\
\text { Лоухский; г. Костомукша }\end{array}$ & . & - \\
\hline 12 & $\begin{array}{l}\text { Хабаровский край - Аяно- } \\
\text { Майский и Охотский районы }\end{array}$ & - & - \\
\hline 13 & $\begin{array}{l}\text { Сахалинская обл. - районы: } \\
\text { Курильский, Ногликский, } \\
\text { Северо-Курильский, Южно- } \\
\text { Курильский и Охинский; } \\
\text { г. Оха }\end{array}$ & - & - \\
\hline 14 & - & $\begin{array}{l}\text { С } 16 \text { мая } 1994 \text { г. в перечень } \\
\text { районов Крайнего Севера } \\
\text { включены территории } \\
\text { Монгун-Тайгинского, } \\
\text { Тоджинского районов } \\
\text { и Шынаанской сельской } \\
\text { администрации Кызылского } \\
\text { района Республики Тыва }\end{array}$ & $\begin{array}{l}\text { Постановление } \\
\text { Правительства } \\
\text { РФ от } 18.07 .1994 \\
\text { № } 856\end{array}$ \\
\hline 15 & - & $\begin{array}{l}\text { С } 1 \text { января } 2013 \text { г. } \\
\text { Березовский и Белоярский } \\
\text { районы Ханты-Мансийского } \\
\text { автономного округа - } \\
\text { Югры отнесены к районам } \\
\text { Крайнего Севера }\end{array}$ & $\begin{array}{l}\text { Постановление } \\
\text { Правительства } \\
\text { РФ от } 03.03 .2012 \\
\text { № } 170\end{array}$ \\
\hline
\end{tabular}

В новейшей истории России после распада СССР государственная политика поддержки регионов Крайнего Севера претерпела существенные изменения. В 1990-е гг. в условиях общего кризиса в экономике, падения уровня 
производства и снижения ВВП, разрушения производственных связей, сформировавшихся в СССР, дефицитности бюджета объем инвестиций, направленных на развитие северных территорий и создание в этих районах новых мощностей, снизился в целом в пять раз (табл. 11).

Таблица 11

Индекс реального объема инвестиций к уровню 1991 г. по некоторым регионам Крайнего Севера

\begin{tabular}{|c|l|c|c|c|c|}
\hline $\begin{array}{c}\text { № } \\
\text { п/п }\end{array}$ & \multicolumn{1}{|c|}{ Субъект РФ } & 1991 г. & 1993 г. & 1996 г. & 1999 г. \\
\hline 1 & Республика Карелия & 1,000 & 0,590 & 0,149 & 0,185 \\
\hline 2 & Республика Коми & 1,000 & 0,718 & 0,307 & 0,196 \\
\hline 3 & Архангельская обл. & 1,000 & 0,613 & 0,227 & 0,209 \\
\hline 4 & Ненецкий АО & 1,000 & 0,598 & 0,192 & 0,176 \\
\hline 5 & Мурманская обл. & 1,000 & 0,638 & 0,212 & 0,287 \\
\hline 6 & Ханты-Мансийский АО & 1,000 & 0,575 & 0,265 & 0,249 \\
\hline 7 & Ямало-Ненецкий АО & 1,000 & 0,439 & 0,344 & 0,334 \\
\hline 8 & Республика Саха (Якутия) & 1,000 & 0,695 & 0,363 & 0,377 \\
\hline 9 & Камчатский край & 1,000 & 0,978 & 0,182 & 0,128 \\
\hline 10 & Магаданская обл. & 1,000 & 0,338 & 0,115 & 0,087 \\
\hline 11 & Чукотский АО & 1,000 & 0,377 & 0,113 & 0,078 \\
\hline
\end{tabular}

* На основе данных Госкомстата РФ.

По отдельным регионам ситуация была еще хуже, в частности, в Магаданской обл. и Чукотском АО объем инвестиций по сравнению с 1991 г. в реальном исчислении снизился более чем в 10 раз. При этом следует отметить, что уровень падения инвестиций в северных регионах был гораздо глубже, чем снижение объемов промышленного производства в 1990-е гг., что позволило Северу в период наиболее острой фазы экономических преобразований в нашей стране формировать значительную долю от совокупного национального дохода ${ }^{11}$.

После распада СССР в течение десятилетия Север был практически лишен государственной поддержки и предоставлен сам себе. Результатом этого стало исчезновение многих северных городов, снижение уровня жизни населения, высокие показатели безработицы, миграционный отток жителей в центральные регионы (численность населения в районах Севера только за 1990-е гг. сократилась примерно на 15 \%, по отдельным регионам эта цифра была еще более внушительной, например, население Магаданской обл. и Чукотки сократилось почти в два раза). Северные надбавки, позволившие значительно повысить привлекательность труда на Севере в советские годы, после развала Советского Союза не компенсировали высокие расходы при проживании в условиях Крайнего Севера, а часто просто игнорировались при использовании серых схем оплаты труда.

\footnotetext{
${ }^{11}$ См. подробнее: [82].
} 
Сложно шел и процесс приватизации на Севере. Многие предприятия, составляющие промышленную основу северных регионов, переходили в частные руки по заниженной стоимости, в процессе приватизации часть предприятий была разворована и обанкрочена.

Правительство РФ предпринимало отдельные усилия по нормализации ситуации и повышению эффективности государственного регулирования развития северных территорий. Так, например, в 1996 г. был принят Федеральный закон «Об основах государственного регулирования социально-экономического развития Севера Российской Федерации» [83]. Но в условиях острого бюджетного дефицита, который существовал в стране в 1990-е, любые государственные инициативы были малоэффективны.

Подтверждением тяжелой экономической ситуации на Севере стало постановление Совета Федерации от 15.05.1997 № 163-СФ [86], в котором констатировалось, что кризис в экономике и социальной сфере северных районов России продолжает нарастать. Снижаются объемы производства, падает уровень жизни людей, закрываются предприятия, увеличивается отток наиболее квалифицированных специалистов. Северные регионы, дающие почти пятую часть национального дохода и основные валютные поступления, оказались в ситуации, когда большая часть поставлена на грань выживания, а ряд из них уже находится за этой гранью. Во многом это явилось следствием того, что проводимая стране экономическая политика не учитывала специфику северных территорий, особенности формирования в них рыночных отношений.

Изменение ситуации в отношении проведения государственной политики регулирования социально-экономического развития Севера стало заметно в начале 2000-х гг. Это было связано, с одной стороны, с ростом понимания значения Крайнего Севера для формирования необходимых темпов развития национального производства, реализации геополитических интересов России, обеспечения военной и экономической безопасности страны, с другой стороны, с улучшением общеэкономической ситуации и увеличением возможностей для финансовой поддержки регионов. В качестве конкретных инструментов государственного регулирования развития Севера в России с 2000-х гг. используются федеральные целевые программы, государственные программы поддержки инвестиционных проектов, фонды выравнивания бюджетной обеспеченности регионов.

Заметную роль в системе мер по поддержке северных регионов в начале XXI в. должна была сыграть государственная программа «Сокращение различий в социально-экономическом развитии регионов Российской Федерации (20022010 годы и до 2015 года)», основной целью которой было сокращение различий в социально-экономическом положении регионов России, уменьшение разрыва по основным показателям социально-экономического развития между наиболее развитыми и отстающими регионами к 2010 г. в 1,5 раза, а к 2015 г. — в 2 раза. Для реализации программы предполагалось отбирать наименее развитые регионы и регионы, в большей степени пострадавшие от кризиса 1990-х гг. В число таких субъектов РФ вошло большинство регионов Крайнего Севера и приравненных к ним. Общий объем заложенных средств для реализации программы составлял более 66 млрд руб., причем предполагалось, что значительная часть из них будет привлечена из внебюджетных источников $(58,4$ \%), остальная часть распределялась между федеральным бюджетом $(18,7 \%)$ и средствами бюджетов субъектов Федерации (22,9 \%). 
Программу «Сокращение различий в социально-экономическом развитии регионов Российской Федерации (2002-2010 годы и до 2015 года)» постигла участь многих федеральных целевых программ тех лет: она была свернута до заявленного срока своего окончания. Основной причиной завершения стала невозможность привлечь финансовые ресурсы для ее реализации в нужных объемах. Наиболее значительные трудности были связаны с привлечением внебюджетных источников (удельный вес внебюджетных источников в финансировании мероприятий программы в первые годы ее реализации составил от 7,8 \% в 2003 г. до 14 \% в 2014 г., что было ниже заявленного уровня в несколько раз). С инвестированием из других источников также возникли серьезные сложности (необходимых ресурсов в региональных бюджетах для софинансирования программы просто не оказалось, а выделение средств из федерального бюджета постоянно корректировалось в меньшую сторону). В результате в 2006 г. распоряжением Правительства от 20.10.2006 № 1454-p [85] программа была полностью прекращена. Несмотря на ее досрочное завершение, определенный положительный эффект был получен: за время действия программы был построен ряд объектов социальной сферы (учреждения образования, здравоохранения, культуры), проведен капитальный ремонт инженерных и инфраструктурных объектов. Кроме того, существенно улучшили свои значения целевые индикаторы: уменьшились различия в социальноэкономическом развитии субъектов Российской Федерации, сократились разрывы по уровню валового регионального продукта на душу населения с учетом покупательной способности, доходам на душу населения, снизилась доля населения, живущего за чертой бедности. Но связывать напрямую недолгий период реализации программы и положительную динамику уровня социальноэкономического развития субъектов РФ было бы неправильно, так как первое десятилетие - это период достаточно быстрого экономического роста по всей России, который был основан на объективных причинах, связанных с положительными тенденциями на мировых сырьевых рынках и значительными усилиями государства по улучшению экономической ситуации в стране.

Несмотря на спорные результаты реализации программы «Сокращение различий в социально-экономическом развитии регионов Российской Федерации» (2002-2010 годы и до 2015 года)», от идеи программного метода развития отдельных территорий в России не отказались и в последние десять лет появилось большое количество стратегических документов и программ различного уровня, направленных на социально-экономическое развитие Севера. Особое значение в этих документах отводилось Арктике как зоне стратегических интересов России.

Главные цели и стратегические приоритеты государственной политики Российской Федерации в Арктике были заложены в стратегическом документе «Основы государственной политики Российской Федерации в Арктике на период до 2020 г. и дальнейшую перспективу» ${ }^{12}$. Принятые в нем положения послужили базой для принятия других значимых документов. Так, в 2013 г. президентом РФ была утверждена Стратегия развития Арктической зоны Российской Федерации и обеспечения национальной безопасности на период до 2020 г., а для обеспечения ее реализации Правительством РФ был сформирован и принят «План мероприятий по реализации Стратегии развития Арктической зоны Российской Федерации и обеспечения национальной безопасности на период до 2020 года», который включал в себя более 80 масштабных мероприятий в области:

12 Утверждены Президентом РФ 18 сентября 2008 г., № Пр-1969. 
комплексного социально-экономического развития арктических регионов; развития науки, высоких технологий и инноваций; развития информационнотелекоммуникационной инфраструктуры; охраны окружающей среды и обеспечения экологической безопасности; развития международного сотрудничества; обеспечения военной безопасности, защиты и охраны государственной границы. При всех положительных моментах принятия и реализации Стратегия развития Арктической зоны РФ нельзя не отметить и ее недостатки, которые не позволяют в полной мере реализовать потенциал развития арктических территорий. Это, во-первых, отсутствие количественных значений целевых индикаторов развития Арктики, которое не позволяет в полной мере оценить эффективность современной государственной северной политики, во-вторых, недостаточно систематизированный механизм реализации стратегии, суть которого во включении мероприятий, вошедших в план по реализации стратегии, в различные государственные программы, которые не предусматривают выделение арктических территорий как отдельного объекта государственного управления.

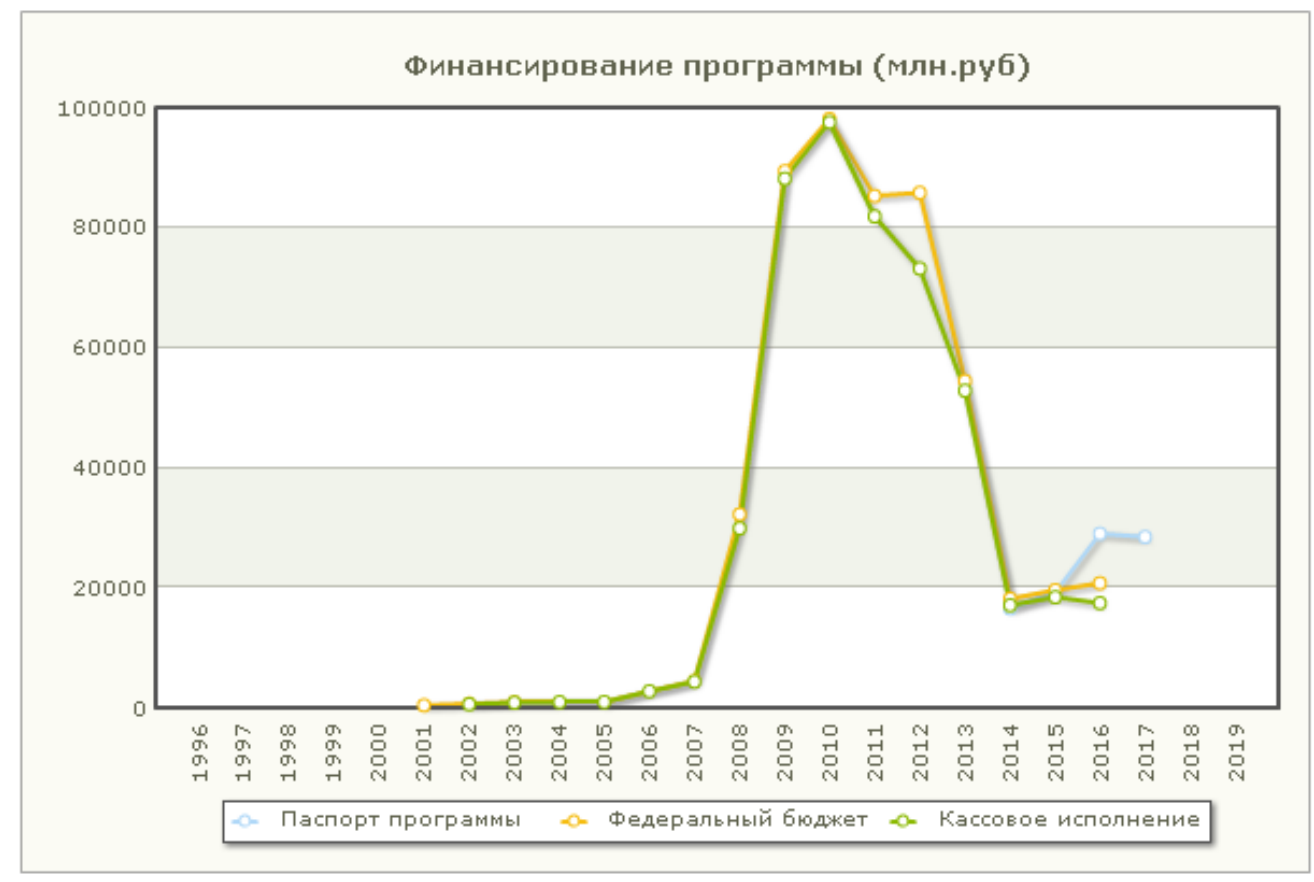

Рис. 11. Финансирование государственных программ развития Дальнего Востока, Байкальского региона (по данным портала «Федеральные целевые программы России»)

С 1996 г. в России принимались и действовали государственные программы развития Дальнего Востока и Байкальского региона [86], но выделение федеральных бюджетных средств на исполнение данных программ началось с 2002 г. Наиболее активный и масштабный период реализации программ приходится на 2008-2016 гг., когда общая сумма кассового исполнения по ним составила более 470 млрд руб. ${ }^{13}$ (рис. 11). Последний вариант программы был утвержден в 2013 г. [88].

${ }^{13}$ По данным портала «Федеральные целевые программы России» [87]. 
В целом, мероприятия программы были направлены на развитие экспортного потенциала Байкальского и дальневосточных регионов (с уклоном на азиатские рынки), на создание территорий опережающего развития с ориентацией на высокотехнологичные перерабатывающие производства, на реализацию крупномасштабных инвестиционных проектов. Большинство проектов предполагало, кроме бюджетного финансирования, привлечение частных внебюджетных источников. Среди северных регионов, развитие которых предусматривалось данными программами, - Иркутская обл., Республика Саха (Якутия), Камчатский и Хабаровский края, Магаданская и Сахалинская обл., Чукотский АО.

На 2019 г. в России действовали две федеральные целевые программы, направленные на развитие отдельных северных регионов: ФЦП «Социальноэкономическое развитие Курильских островов (Сахалинская область) на 20162025 годы» (объем финансирования в 2019 г. - около 0,35 млрд руб.) и ФЦП «Развитие Республики Карелия на период до 2020 года» (объем финансирования в 2019 г. — около 3,3 млрд руб.).

К инструментам финансового регулирования развития северных территорий в России относится система межбюджетных трансфертов, за счет которых региональным бюджетам выделяются дополнительные финансовые ресурсы. Законодательство не предусматривает специальных условий для выделения средств северным субъектам РФ, к ним применяются общие нормативно установленные условия. В 2019 г. из 14 субъектов, отнесенных к регионам Крайнего Севера, 10 субъектов получают дотации на выравнивание бюджетной обеспеченности регионов (рис. 12). По объемам выделенных дотаций Республика Саха (Якутия) и Камчатский край занимают 2-е и 3-е место среди всех регионов России.

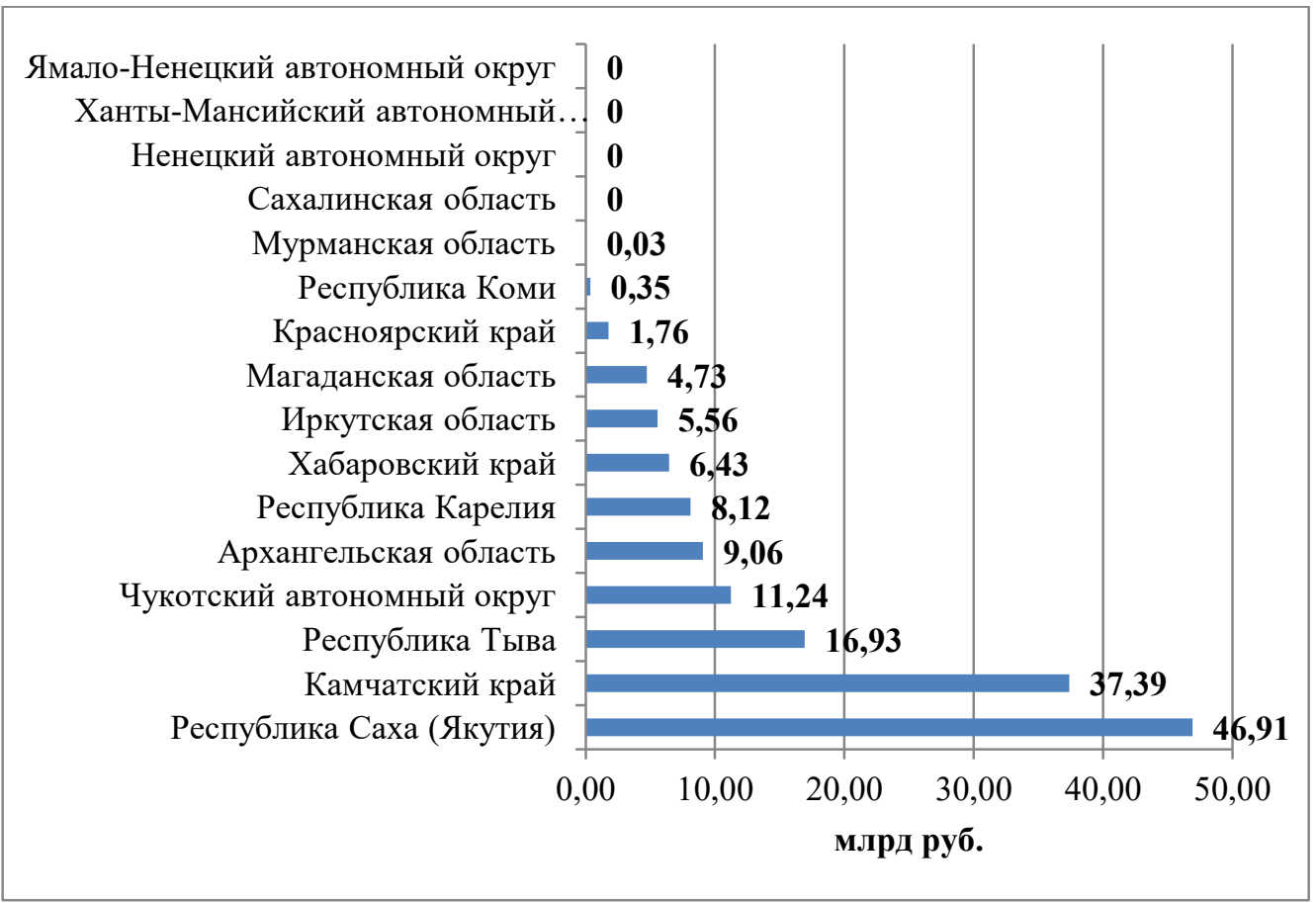

Рис. 12. Объемы дотаций регионам Крайнего Севера на выравнивание бюджетной обеспеченности в 2019 г. 
В России применяются и другие финансовые инструменты регулирования развития северных территорий. Среди них создание особых экономических зон (ОЭ3) для привлечения зарубежного и отечественного капитала. Опыт создания такой зоны имеется в Магаданской обл. с 1999 г. [89]. Участникам ОЭЗ, согласно закону, предоставлялись льготы по уплате налогов, зачисляемых в федеральный бюджет (в частности, налога на прибыль), а товары, ввозимые из-за границы, размещаются и используются на территории ОЭЗ без применения к ним таможенных пошлин и нетарифных методов ограничений. Несмотря на наличие проблем и объективных трудностей, связанных, прежде всего, с нестабильностью правового поля функционирования ОЭЗ, ее создание оказало благоприятное влияние на регион: сформировало предпосылки для положительной динамики ключевых региональных показателей развития (индекс промышленного производства, динамика инвестиций в основной капитал), обеспечило рост инвестиционной привлекательности Магаданской обл., способствовало увеличению численности занятых в экономике (см. подробнее: [90]). В 2014 г. работа особой экономической зоны в Магаданской обл. была продлена до 2025 г. [91].

В России продолжает действовать система льгот и гарантий для лиц, работающих в районах Крайнего Севера и приравненных к ним ${ }^{14}$. В частности, для северян действуют процентные надбавки (районные коэффициенты и полярные надбавки) на оплату труда, предусмотрены дополнительный северный отпуск, льготные условия выхода на пенсию, установлены компенсация транспортных расходов на проезд в отпуск, «северные» жилищные субсидии.

Действующая система государственного регулирования развития районов Севера также включает в себя поддержку базовых отраслей, регулирование рынков труда, охрану окружающей среды, создание эффективной системы социальной поддержки коренных малочисленных народов Севера, поддержку завоза продукции в районы Севера и транспортной системы в районах Севера, меры поддержки отдельных объектов, хозяйственных комплексов и населенных пунктов, регулируемые региональными нормативными актами.

В последние годы расширяются права и полномочия субъектов Федерации в области политики государственной поддержки и социальной защиты населения. Доходная часть их бюджетов пополняется благодаря увеличению поступления платежей за пользование природными ресурсами, предоставлению им права распоряжаться природными ресурсами (в первую очередь биологическими) и лицензированию различных видов хозяйственной деятельности. В долгосрочной перспективе предполагается постепенная передача функций государственной поддержки различных объектов на региональный уровень.

Вместе с тем сложившаяся система государственной поддержки районов Севера недостаточно учитывает произошедшие изменения в экономике России, мало эффективна в силу ряда причин институционального, нормативноправового и конъюнктурного характера. К ним можно отнести и трансфертный характер формирования бюджетных доходов большинства субъектов РФ,

${ }^{14}$ В настоящее время регулируются Законом РФ «О государственных гарантиях и компенсациях для лиц, работающих и проживающих в районах Крайнего Севера и приравненных к ним местностях» от 19.02.1993 № 4520-1 [92]. 
и мощный отток финансовых ресурсов из районов Крайнего Севера, и исполнение приватизированными предприятиями функций по содержанию объектов социальной сферы и жилищно-коммунального хозяйства, и ряд других. Существующие подходы к решению экономических, социальных, демографических проблем не позволяют эффективно реализовывать имеющийся природноресурсный и производственный потенциал северных регионов, создавать условия для их устойчивого и динамичного развития.

Дальнейшие условия для развития северных территорий сможет создать принятие федеральных законов «Об Арктической зоне Российской Федерации» и «О государственной поддержке предпринимательской деятельности в Арктической зоне РФ», обсуждение которых в настоящее время активно ведется на различных общественных площадках. 


\section{3. ОЦЕНКА И ИСПОЛЬЗОВАНИЕ ФИНАНСОВОГО ПОТЕНЦИАЛА ДЛЯ ФИНАНСОВОГО РЕГУЛИРОВАНИЯ РАЗВИТИЯ СЕВЕРНЫХ РЕГИОНОВ}

\section{1. Оценка финансового потенциала северных регионов}

В современных условиях решение большинства проблем жизнеобеспечения населения сосредоточивается на региональном уровне. Органы власти регионов вынуждены самостоятельно решать проблемные задачи: внедрение новых технологий; организация выпуска конкурентоспособных товаров; комплекс социальных вопросов; повышение качества жизни населения и др. Кроме того, руководители субъектов Федерации вынуждены самостоятельно разрабатывать планы социально-экономического развития территории, координировать связи с другими регионами и субъектами экономики, совершенствовать мотивацию действий всех участников финансово-хозяйственной деятельности территории. Особую важность приобретают вопросы финансовой самостоятельности и финансовой обеспеченности регионов, решение которых в значительной степени зависит от структуры экономики и уровня ее развития на соответствующей территории.

Совершенствование механизмов формирования, использования и управления финансовыми ресурсами региона является одной из первостепенных задач, решение которой необходимо для обеспечения сбалансированного развития региона.

Как было установлено ранее, уровень финансового обеспечения региона характеризует финансовый потенциал. Оценка финансового потенциала служит мерой сравнения возможностей формирования финансовых ресурсов региона, позволяет проводить группировку регионов, исследовать и оценивать состояние конкретного северного региона в соответствии с полученной количественной оценкой финансового потенциала и его составляющих [93].

В настоящее время очень важным является построение таких финансовых отношений, которые позволили бы формировать и использовать финансовый потенциал регионов с максимальным экономическим и социальным эффектом.

Финансовый потенциал формируется за счет накопленных, привлекаемых и образующихся в результате функционирования финансовой системы региона финансовых ресурсов и используется субъектами экономических отношений в различных секторах регионального хозяйства. Максимальное привлечение всех финансовых ресурсов, которыми располагает регион, будет способствовать эффективному сбалансированному его функционированию и развитию.

В настоящее время асимметрия в социально-экономическом развитии субъектов РФ связана именно с различиями в обеспеченности регионов финансовыми ресурсами. Применяемые Правительством РФ инструменты горизонтального и вертикального выравнивания развития территорий усилили финансовую зависимость регионов от вышестоящего уровня. А это, в свою очередь, привело к снижению активности органов власти субъектов РФ в разработке механизмов, которые способствуют наращиванию ресурсной базы 
территории, к снижению их заинтересованности в укреплении своего финансового потенциала. Решение задачи достижения финансовой независимости региона невозможно без оценки имеющихся в распоряжении региона финансовых ресурсов - основы финансового потенциала.

Региональный финансовый потенциал является индикатором, который определяет реакцию экономики субъекта РФ на принимаемые управленческие решения, позволяет сопоставить финансовые возможности различных регионов, оценить конкурентоспособность конкретного региона.

Возможности субъектов Российской Федерации в формировании финансового потенциала различны в силу природно-климатических условий, уровня развития производства, демографических параметров, наличия или отсутствия природных и финансовых ресурсов. В этих условиях важным является правильное распределение ограниченных финансовых ресурсов, выбор наиболее действенных форм финансовой поддержки, эффективных методов привлечения дополнительных финансовых средств. Этим должны заниматься и федеральные, и региональные власти. Особенно важным решение данных задач представляется для северных и приравненных к северным регионов, которые характеризуются наличием стратегических сырьевых ресурсов, большим количеством ресурсоемких отраслей и производств, монополизированностью рынков, высокой степенью социальной незащищенности населения и вносят значительный вклад в экономическое развитие и доходы бюджетной системы страны. Финансовая обеспеченность этих территорий остается низкой.

Причин этого несколько: существующая практика бюджетного выравнивания, современная система налоговых льгот, неэффективное использование региональными властями имеющихся финансовых рычагов и т. д. Не способствует повышению финансовой обеспеченности регионов Крайнего Севера и нерациональная структура распределения налоговых доходов между звеньями бюджетной системы.

Северные регионы существенно различаются по уровню регионального финансового потенциала в целом и отдельных составляющих его элементов в частности [94, с. 100-107]. Большая часть северных субъектов РФ испытывает потребность в привлечении дополнительных финансовых ресурсов [95], характеризуется различными уровнями экономической безопасности [96].

Значения отдельных показателей ${ }^{15}$, характеризующих каждый из элементов финансового потенциала северных субъектов РФ, представлены в табл. $12-15^{16}$. Более подробно расчеты по отдельным финансовым составляющим финансового потенциала региона приведены в работе [97].

В табл. 12 даны значения относительных показателей, характеризующих бюджетно-налоговый потенциал регионов Крайнего Севера.

15 Исходные абсолютные значения показателей, используемые авторами для расчета относительных коэффициентов по каждому элементу финансового потенциала, приводятся в зарегистрированной базе данных «Оценка финансового потенциала северных и приравненных к северным регионов Российской Федерации за 2005, 2010, 2015 годы».

16 Значения показателей в табл. 12-14 рассчитаны на основе данных 2015 г. 
Бюджетно-налоговый потенциал регионов Крайнего Севера

\begin{tabular}{|c|c|c|c|c|}
\hline Регион & $\begin{array}{c}\text { Коэффициент } \\
\text { покрытия расходов }\end{array}$ & $\begin{array}{c}\text { Коэффициент концентрации } \\
\text { собственных доходов }^{* *}\end{array}$ & $\begin{array}{c}\text { Коэффициент } \\
\text { обеспеченности населения } \\
\text { налоговыми платежами*** }^{*}\end{array}$ & $\begin{array}{c}\text { Отношение дефицита } \\
\text { консолидированного бюджета } \\
\text { к величине расходов }\end{array}$ \\
\hline Республика Карелия & 0,629 & 0,697 & 37,8 & $-0,098$ \\
\hline Республика Коми & 0,799 & 0,901 & 176,7 & $-0,114$ \\
\hline Ненецкий АО & 0,850 & 0,951 & 1387,3 & $-0,106$ \\
\hline Архангельская обл. & 0,730 & 0,756 & 55,7 & $-0,034$ \\
\hline Мурманская обл. & 0,875 & 0,894 & 82,1 & $-0,022$ \\
\hline Ханты-Мансийский АО & 0,969 & 0,943 & 1227,7 & 0,027 \\
\hline Ямало-Ненецкий АО & 0,965 & 0,971 & 1459,9 & $-0,006$ \\
\hline Республика Тыва & 0,237 & 0,250 & 14,5 & $-0,054$ \\
\hline Красноярский край & 0,783 & 0,861 & 123,5 & $-0,091$ \\
\hline Иркутская обл. & 0,768 & 0,827 & 82,0 & $-0,071$ \\
\hline Республика Саха (Якутия) & 0,632 & 0,646 & 160,9 & $-0,023$ \\
\hline Камчатский край & 0,391 & 0,392 & 85,4 & $-0,004$ \\
\hline Хабаровский край & 0,730 & 0,820 & 72,2 & $-0,110$ \\
\hline Магаданская обл. & 0,568 & 0,682 & 110,9 & $-0,166$ \\
\hline Сахалинская обл. & 1,026 & 0,977 & 545,5 & 0,050 \\
\hline Чукотский АО & 0,605 & 0,559 & 296,6 & 0,082 \\
\hline Российская Федерация & $\mathbf{0 , 8 0 4}$ & $\mathbf{0 , 8 1 9}$ & 94,2 & $-0,018$ \\
\hline
\end{tabular}

" Отношение собственных бюджетных доходов к совокупным расходам.

** Отношение собственных бюджетных доходов к совокупным доходам бюджета.

${ }^{* * *}$ Отношение поступлений налогов в регионе на душу населения, тыс. руб/чел. 
Финансовый потенциал населения регионов Крайнего Севера

\begin{tabular}{|c|c|c|c|c|}
\hline \multirow[b]{2}{*}{ Регион } & \multicolumn{2}{|c|}{ Коэффициент, характеризующий отношение } & \multirow[b]{2}{*}{$\begin{array}{c}\text { Прирост } \\
\text { финансовых активов, } \\
\text { тыс. руб/чел. }\end{array}$} & \multirow{2}{*}{$\begin{array}{c}\text { Численность населения с денежными } \\
\text { доходами выше величины } \\
\text { прожиточного минимума, } \\
\text { \% от общей численности населения }\end{array}$} \\
\hline & $\begin{array}{c}\text { сбережений } \\
\text { домашних хозяйств } \\
\text { к общим доходам } \\
\end{array}$ & $\begin{array}{c}\text { среднедушевого дохода } \\
\text { в регионе к прожиточному } \\
\text { минимуму }\end{array}$ & & \\
\hline Республика Карелия & 0,284 & 2,224 & 44,2 & 83,6 \\
\hline Республика Коми & 0,373 & 2,761 & 78,4 & 85,4 \\
\hline Ненецкий АО & 0,660 & 3,790 & 427,2 & 90,3 \\
\hline Архангельская обл. & 0,302 & 2,418 & 68,8 & 84,5 \\
\hline Мурманская обл. & 0,325 & 2,715 & 71,7 & 87,3 \\
\hline Ханты-Мансийский АО & 0,405 & 3,104 & 90,9 & 87,3 \\
\hline Ямало-Ненецкий АО & 0,558 & 4,245 & 293,7 & 92,5 \\
\hline Республика Тыва & 0,512 & 1,595 & 69,0 & 61,8 \\
\hline Красноярский край & 0,312 & 2,559 & 52,4 & 81,2 \\
\hline Иркутская обл. & 0,395 & 2,288 & 62,8 & 80 \\
\hline Республика Саха (Якутия) & 0,362 & 2,439 & 80,8 & 81,1 \\
\hline Камчатский край & 0,461 & 2,231 & 130,2 & 82,1 \\
\hline Хабаровский край & 0,285 & 2,731 & 70,0 & 86,3 \\
\hline Магаданская обл. & 0,495 & 2,877 & 167,7 & 86,8 \\
\hline Сахалинская обл. & 0,339 & 3,669 & 113,8 & 90,4 \\
\hline Чукотский АО & 0,698 & 3,663 & 386,5 & 91,1 \\
\hline Российская Федерация & $\mathbf{0 , 2 9 0}$ & 3,224 & 55,6 & 86,7 \\
\hline
\end{tabular}


Финансовый потенциал коммерческих и некоммерческих организаций регионов Крайнего Севера

\begin{tabular}{|c|c|c|c|c|}
\hline Регион & $\begin{array}{c}\text { Коэффициент, } \\
\text { характеризующий } \\
\text { сальдированный финансовый } \\
\text { результат хозяйствующих } \\
\text { субъектов на одно предприятие } \\
\text { или организацию, млн руб. } \\
\end{array}$ & $\begin{array}{c}\text { Коэффициент автономии } \\
\text { (доля собственных средств } \\
\text { в валюте баланса) } \\
\text { (нормальное ограничение } \\
\text { больше либо равно } 50 \text { \%), \% }\end{array}$ & $\begin{array}{c}\text { Коэффициент, } \\
\text { характеризующий среднюю } \\
\text { рентабельность проданных } \\
\text { товаров, продукции, работ, } \\
\text { услуг хозяйствующих } \\
\text { субъектов } \\
\end{array}$ & $\begin{array}{c}\text { Коэффициент, } \\
\text { характеризующий } \\
\text { долю неубыточных } \\
\text { хозяйствующих } \\
\text { субъектов }\end{array}$ \\
\hline Республика Карелия & 0,431 & 20,02 & 9,9 & 0,547 \\
\hline Республика Коми & 3,051 & 66,89 & 9,6 & 0,616 \\
\hline Ненецкий АО & $-7,784$ & 48,14 & 15,6 & 0,649 \\
\hline Архангельская обл. & 0,943 & 19,73 & 9,2 & 0,667 \\
\hline Мурманская обл. & 3,610 & 50,67 & 25,7 & 0,553 \\
\hline Ханты-Мансийский АО & 30,469 & 82,04 & 15,4 & 0,713 \\
\hline Ямало-Ненецкий АО & 3,703 & 24,08 & 16,6 & 0,552 \\
\hline Республика Тыва & $-2,151$ & $-17,42$ & 11,2 & 0,629 \\
\hline Красноярский край & 3,460 & 34,93 & 22,9 & 0,683 \\
\hline Иркутская обл. & 2,721 & 65,07 & 14,2 & 0,706 \\
\hline Республика Саха (Якутия) & 0,913 & 50,48 & 26,1 & 0,668 \\
\hline Камчатский край & 1,102 & 36,68 & 11,3 & 0,636 \\
\hline Хабаровский край & $-0,407$ & 28,29 & 6,1 & 0,596 \\
\hline Магаданская обл. & 3,715 & 57,52 & 13,7 & 0,591 \\
\hline Сахалинская обл. & 0,959 & 53,39 & 7,8 & 0,669 \\
\hline Чукотский АО & 19,273 & 62,17 & 34,7 & 0,524 \\
\hline Российская Федерация & 1,488 & 47,41 & 7,2 & 0,674 \\
\hline
\end{tabular}


Потенциал финансово-кредитной системы регионов Крайнего Севера

\begin{tabular}{|c|c|c|c|c|}
\hline \multirow[b]{2}{*}{ Регион } & \multirow{2}{*}{$\begin{array}{c}\text { Коэффициент оценки доли } \\
\text { привлеченных источников } \\
\text { (за исключением средств } \\
\text { бюджетов) в структуре } \\
\text { инвестиций }\end{array}$} & \multicolumn{3}{|c|}{ Коэффициент, характеризующий } \\
\hline & & $\begin{array}{c}\text { уровень задолженности } \\
\text { юридических лиц } \\
\text { по кредитам, млн руб/ед. }\end{array}$ & $\begin{array}{c}\text { объем вкладов в кредитные } \\
\text { организации региона } \\
\text { к объему ВРП }\end{array}$ & $\begin{array}{c}\text { количество кредитных } \\
\text { организаций и филиалов } \\
\text { в расчете на } 10 \text { тыс. } \\
\text { жителей региона } \\
\end{array}$ \\
\hline Республика Карелия & 0,302 & 1,368 & 0,317 & 0,158 \\
\hline Республика Коми & 0,412 & 1,593 & 0,214 & 0,128 \\
\hline Ненецкий АО & 0,336 & 12,539 & 0,036 & 0,229 \\
\hline Архангельская обл. & 0,274 & 6,607 & 0,342 & 0,115 \\
\hline Мурманская обл. & 0,165 & 3,973 & 0,387 & 0,183 \\
\hline Ханты-Мансийский АО & 0,125 & 4,356 & 0,155 & 0,093 \\
\hline Ямало-Ненецкий АО & 0,423 & 25,747 & 0,054 & 0,093 \\
\hline Республика Тыва & 0,538 & 1,408 & 0,148 & 0,127 \\
\hline Красноярский край & 0,398 & 9,467 & 0,182 & 0,108 \\
\hline Иркутская обл. & 0,164 & 3,408 & 0,328 & 0,079 \\
\hline Республика Саха (Якутия) & 0,300 & 11,828 & 0,148 & 0,115 \\
\hline Камчатский край & 0,048 & 3,671 & 0,388 & 0,316 \\
\hline Хабаровский край & 0,316 & 5,633 & 0,552 & 0,210 \\
\hline Магаданская обл. & 0,719 & 3,529 & 0,424 & 0,204 \\
\hline Сахалинская обл. & 0,347 & 1,668 & 0,253 & 0,205 \\
\hline Чукотский АО & 0,253 & 6,648 & 0,160 & 0,199 \\
\hline Российская Федерация & 0,315 & 5,925 & 0,560 & 0,146 \\
\hline
\end{tabular}


По коэффициенту покрытия расходов 11 регионов из 16 имеют значения ниже среднероссийских, самые низкие значения данного показателя у Республики Тыва и Камчатского края - 0,237 и 0,391 соответственно. У 5 регионов (Ненецкий, Ханты-Мансийский, Ямало-Ненецкий автономные округа, Мурманская и Сахалинская обл.) он превышает среднероссийское значение.

По коэффициенту концентрации собственных доходов 9 регионов имеют значения выше среднероссийских, остальные 7 - ниже. У Республики Тыва и Камчатского края самые низкие показатели.

По коэффициенту обеспеченности населения налоговыми платежами резко выделяются три региона - Ненецкий, Ханты-Мансийский и ЯмалоНенецкий автономные округа, имеющие значения, превышающие среднероссийские в 13-15 раз. Республика Тыва и Камчатский край имеют самые низкие показатели.

В табл. 13 приведены значения относительных показателей, которые характеризуют финансовый потенциал исследуемой группы регионов. Все регионы Крайнего Севера, кроме Республики Карелия, имеют значения коэффициента, характеризующего отношение сбережений населения к общим доходам, выше среднероссийского показателя. Коэффициент, показывающий отношение среднедушевого дохода к прожиточному уровню в регионе, только у 4 регионов превышает среднероссийское значение (Ненецкий, ЯмалоНенецкий, Чукотский автономные округа и Сахалинская обл.), почти на уровне среднероссийского - у Ханты-Мансийского АО, для остальных - он ниже среднероссийского. Практически все регионы имеют показатель численности населения с денежными доходами выше прожиточного минимума на уровне или выше среднероссийского значения, исключением является Республика Тыва, у которой этот показатель ниже среднероссийского.

В табл. 14 представлены значения относительных характеристик, отражающих потенциал коммерческих и некоммерческих организаций регионов Крайнего Севера.

Значения коэффициента, характеризующего финансовый потенциал хозяйствующих субъектов, в целом показывают явное преимущество ХантыМансийского АО перед остальными регионами, самые низкие значения показателя отмечаются у Республики Тыва.

Сведения о потенциале финансово-кредитной системы регионов Крайнего Севера представлены в табл. 15. По коэффициентам, характеризующим потенциал финансово-кредитной сферы, можно выделить Ямало-Ненецкий $\mathrm{AO}$, остальные регионы имеют показатели на уровне среднероссийского (таких немного) или ниже среднероссийского значений.

Остановимся более подробно на характеристиках финансового потенциала каждого региона.

Ханты-Мансийский автономный округ - Югра - один из стратегических регионов России, формирующий безопасность страны в сфере энергетики и обеспечивающий значительный приток финансовых ресурсов в том числе и в федеральный бюджет, за счет добычи и экспорта полезных ископаемых. Регион является крупнейшим нефтедобывающим субъектом РФ, входит в число лидеров по добыче природного и попутного газа. Ханты-Мансийский автономный округ занимает 3-е место в рейтинге социально-экономического положения регионов сразу после Москвы и Санкт-Петербурга. 
Благодаря высокому уровню развития промышленности регион сформировал и высокий уровень финансового потенциала. Ханты-Мансийский автономный округ относится к немногочисленной группе регионов-доноров. По показателям обеспеченности населения налоговыми платежами и концентрации собственных доходов в совокупных доходах бюджета регион входит в число лидеров в нашей стране. Среди всех северных субъектов в Югре наибольшее значение сальдированного финансового результата на один хозяйствующий субъект и минимальная доля убыточных субъектов. Наличие большого количества крупных промышленных гигантов, работающих там, позволяет обеспечивать высокий уровень среднедушевых доходов (даже при значительном уровне прожиточного минимума) и, как следствие, высокие значения доли сбережений в структуре доходов и прироста финансовых активов у домохозяйств.

Ямало-Ненеикий автономный округ является одновременно самостоятельным субъектом РФ и входит в состав Тюменской обл. Около половины валового регионального продукта формирует добыча полезных ископаемых. На долю округа в настоящий момент приходится свыше $50 \%$ от общероссийского объема добычи природного и попутного газа (здесь и далее показатели развития регионов приводятся на основании работ [98, 99]). Это один из немногих регионов, население которого за последние несколько десятков лет не только не уменьшилось, но и возросло.

По совокупному финансовому потенциалу Ямало-Ненецкий автономный округ является лидером среди регионов Арктической зоны, всех регионов Крайнего Севера и приравненным к ним территориям.

Бюджет автономного округа характеризуется достаточно высокой степенью самостоятельности (доля собственных доходов регионального бюджета превышает $95 \%$, а дефицит консолидированного бюджета округа в 2014-2015 гг. не превышал $2 \%$ ). По уровню налоговых поступлений в бюджетную систему на человека регион относится к группе лидеров.

Все показатели финансового потенциала домашних хозяйств ЯмалоНенецкого автономного округа находятся на высоком уровне. Среднедушевые доходы населения составляют около 63 тыс. руб. в месяц (2016 г.), значительны также показатели склонности к сбережениям, прироста финансовых активов. Доля населения с доходами ниже прожиточного минимума примерно в 2 раза ниже, чем в среднем по стране.

Несмотря на некоторое снижение показателей потенциала хозяйствующих субъектов в последние годы, они остаются достаточно высокими. Регион входит в число лидирующих по коэффициенту, характеризующему размер финансовых вложений на одно предприятие, средний уровень рентабельности реализации товаров, работ и услуг составляет порядка $20 \%$.

Высокой оценки заслуживает и потенциал финансово-кредитной сферы. Несмотря на отсутствие региональных кредитных организаций в округе, банки достаточно активно участвуют в кредитовании реального сектора, что подтверждает высокая доля привлеченных источников (за исключением средств бюджетов) в структуре инвестиций региона.

Красноярский край - субъект Сибирского федерального округа РФ входит в состав Восточно-Сибирского экономического района. По площади территории занимает 2-е место среди субъектов РФ, население региона - более 2,8 млн чел. Красноярский край — один из немногих северных регионов, где 
в структуре валового регионального продукта преобладает не добыча полезных ископаемых (доля которой составляет около 17 \%), а обрабатывающие производства (цветная металлургия, машиностроение). Доля обрабатывающей промышленности составляет более 31 \% в ВРП края.

Красноярский край, в целом, характеризуется средним уровнем финансового потенциала.

Бюджет региона является дефицитным (в 2015 г. дефицит превысил 10 \% от совокупных объемов доходов), при этом доля собственных бюджетных доходов превышает $85 \%$. По обеспеченности населения налоговыми платежами регион значительно уступает лидерам, но входит в первую двадцатку субъектов Федерации.

Финансовый потенциал домашних хозяйств региона невысок. Причиной этого, прежде всего, являются сравнительно низкие для северного региона среднедушевые доходы населения (в 2015 г. около 27 тыс. руб. в месяц).

Финансовый потенциал хозяйствующих субъектов - сильная сторона финансового потенциала Красноярского края. Регион имеет развитую промышленность. По показателям объема производства товаров и услуг на одного жителя, инвестиций в основной капитал хозяйствующих субъектов, доле прибыльных предприятий в 2015 г. край входил в 15 ведущих субъектов РФ.

Потенциал кредитно-финансовой сферы Красноярского края может быть охарактеризован как умеренный: с одной стороны, в крае широкая сеть региональных кредитных организаций и высока доля участия банков в финансировании инвестиционной деятельности предприятий и организаций, с другой стороны, с другой - регион характеризуется низким уровнем отношения объема вкладов к ВРП.

Высокими показателями финансового потенциала хозяйствующих субъектов отличается Иркутская обл. - субъект, расположенный в юговосточной части Сибирского федерального округа. Регион выделяется как с позиции общих характеристик (5-е место среди регионов РФ по площади), так и с точки зррения вклада в экономику (по общему объему производимого ВРП Иркутская обл. находится на 16-м месте). Основными отраслями, на которых специализируется регион, являются деревообрабатывающая, целлюлознобумажная, горнодобывающая, машиностроение.

Существенный финансовый потенциал хозяйствующих субъектов Иркутской обл. обеспечивается в первую очередь за счет большого количества значимых промышленных предприятий, высокой средней рентабельности экономики региона (примерно в 2 раза выше среднероссийского значения) и высокой устойчивости организаций.

При высоком финансовом потенциале хозяйствующих субъектов Иркутская обл. имеет средние и ниже средних показатели по бюджетноналоговому потенциалу (бюджет региона является дотационным, а уровень обеспеченности населения налоговыми платежами - ниже среднероссийского уровня) и потенциалу домашних хозяйств (по соотношению среднедушевых доходов и прожиточного минимума область находится на одном из последних мест среди северных субъектов РФ). Уровень финансового потенциала кредитнофинансовой сферы, как и у большинства северных регионов, нельзя отнести к сильным сторонам области. 
Республика Тыва - субъект РФ, расположенный на юге Сибирского федерального округа с численностью населения около 320 тыс. чел. К районам Крайнего Севера в регионе относятся три муниципальных района.

Уровень развития Тывы можно оценить как крайне низкий. В рейтинге социально-экономического положения субъектов Федерации Республика Тыва стабильно занимает последние места. Аналогична ситуация и по другим индикаторам регионального развития, в структуре отраслей экономики преобладает сельское хозяйство. Доля Республики Тыва в совокупном ВРП России менее $0,1 \%$, а в ВРП Сибирского федерального округа менее $1 \%$. При этом регион характеризуется одними из самых высоких показателей прироста численности населения в стране.

По уровню финансового потенциала среди всех северных субъектов Республика Тыва занимает последнее место. Бюджет региона дефицитный, доля собственных доходов в совокупных доходах бюджета меньше среднероссийского значения в 3,5 раза. Уровень среднедушевых доходов к прожиточному минимуму 1,6 , что является самым низким показателем среди всех северных регионов. При этом уровень доли сбережений в общих доходах в 2 раза превышает среднероссийские значения. Это объясняется спецификой занятости населения ведение собственного хозяйства, что позволяет в значительной степени обеспечивать себя самостоятельно всеми необходимыми продуктами. В последние годы регион характеризуется отрицательным финансовым результатом хозяйствующих субъектов и чрезвычайно низким средним показателем автономии.

Республика Саха (Якутия) - субъект Дальневосточного федерального округа, также входит в одноименный экономический район. Представляет собой самый большой регион не только в Российской Федерации, но и наибольшую административно-территориальную единицу в мире. При этом население Якутии менее 1 млн чел. Как и во многих других арктических регионах, в структуре ВРП республики преобладает добыча полезных ископаемых (ее доля составляет 45 \%). Среди добываемых полезных ископаемых - алмазы, золото, нефть, газ, уголь и многие другие.

По уровню бюджетно-налогового потенциала регион следует отнести к средней группе субъектов РФ. С одной стороны, бюджет Якутии дефицитный (размер дефицита в 2015 г. составлял порядка 3,5 \% от общего объема доходов), доля собственных доходов к совокупным доходам невысока (около $65 \%$ ), с другой - по объему доходов консолидированного бюджета на одного жителя Республика Саха в 2015 г. входила в первую шестерку российских регионов.

Аналогично характеризуется Якутия и по уровню финансового потенциала домашних хозяйств. Уровень среднедушевых доходов населения республики в 2015 г. составлял 38 тыс. руб. в месяц, что равнялось $235 \%$ от стоимости фиксированного набора товаров и услуг в регионе. При этом показатели склонности населения к сбережениям и прироста финансовых активов в регионе достаточно высоки.

Республика Саха характеризуется достаточно высоким финансовым потенциалом хозяйствующих субъектов. По объему инвестиций в основной капитал на одного жителя Якутия входит в первую десятку регионов в России. Также высокими являются показатели средней рентабельности проданных товаров, работ, услуг (2015 г. - 31\%) и доли прибыльных организаций в экономике (2015 г. $-69 \%)$. 
Уровень кредитно-финансового потенциала Якутии может быть определен как умеренный. Республика в достаточной степени обеспечена структурными подразделениями кредитных учреждений, также созданы два региональных банка, при этом доля кредитных ресурсов в структуре источников финансирования инвестиций в основной капитал хозяйствующих субъектов невысока. Также низкие значения имеет коэффициент, характеризующий объем вкладов в кредитные организации к валовому региональному продукту.

Камчатский край - субъект РФ, расположенный в Дальневосточном федеральном округе, с населением около 315 тыс. чел. Его спецификой является восточное расположение. Основная отрасль хозяйства Камчатки - рыбная промышленность (лов рыбы и переработка морепродуктов). Также развиты сельское хозяйство, добыча природного газа, угля. По уровню ВРП на душу населения в последние годы регион входит в число первых 15 субъектов РФ. Камчатский край имеет высокие оценки инвестиционной привлекательности, главным образом за счет географического расположения, близости Японии, Североамериканского континента и наличия территории с особым правовым режимом.

Финансовый потенциал Камчатского края невысок, чему причиной является, прежде всего, низкая оценка бюджетно-налогового потенциала. В последние годы здесь формировался дефицитный бюджет, невысока доля собственных доходов в общей совокупности доходов бюджета. По значению коэффициента обеспеченности населения налоговыми платежами регион уступает большей части северных субъектов. Высокое значение прожиточного минимума, несмотря на достаточно высокий уровень среднедушевых доходов, не позволяет формировать населению Камчатского края масштабный прирост финансовых активов, что, в свою очередь, ограничивает привлечение средств населения в экономику. Регион характеризуется средними по отношению к российскому уровню показателями рентабельности в экономике и доли неубыточных предприятий. Активность банков по привлечению финансовых ресурсов и кредитованию хозяйственных субъектов в Камчатском крае невысока.

Еще одним дальневосточным северным регионом является Сахалинская обл., которая располагается на одноименном острове и островах Курильской гряды. При невысокой численности населения (менее 500 тыс. чел.) регион занимает 3-е место в России после Ненецкого и Ямало-Ненецкого автономных округов по показателю ВРП на душу населения. Сахалинская обл. обладает значительным природно-ресурсным потенциалом. Регион богат биологическими морскими ресурсами, в нем сосредоточены запасы газового конденсата, угля и нефти. За счет развития технологий в последние годы удалось реализовать ряд проектов по добыче природных ресурсов Сахалина. Регион имеет один из самых высоких показателей инвестиционной привлекательности и инвестиционного климата.

В последние два десятилетия финансовый потенциал Сахалинской обл. значительно вырос, прежде всего, за счет таких составляющих, как бюджетноналоговый потенциал (в регионе профицитный бюджет с долей собственных доходов, близкой к 1, по обеспеченности населения налоговыми платежами область более чем в 5 раз превышает среднероссийский уровень) и финансовый потенциал населения (доля населения с денежными доходами выше прожиточного 
минимума в регионе выше $90 \%$, а уровень среднедушевых доходов превышает среднероссийское значение более чем в 1,5 раза). По двум другим составляющим финансового потенциала Сахалинской обл. значения индикаторов сопоставимы со средними показателями по северным регионам.

Магаданская обл., как и Сахалинская, находится в Дальневосточном федеральном округе, но, в отличие от последней, располагается на континенте. Являясь по площади территории одиннадцатым субъектом РФ, по численности населения (около 145 тыс. человек) регион занимает 83-е место. Больше всего добавленной стоимости в регионе образуется в отрасли добычи полезных ископаемых. К основным видам природных ресурсов в Магаданской обл. следует отнести запасы благородных и цветных металлов, углеводородов. За счет малой численности населения по показателю ВРП на душу населения регион входит в первую десятку общероссийского рейтинга.

По уровню финансового потенциала среди северных субъектов РФ Магаданская обл. находится ближе к регионам-лидерам, чем к регионамаутсайдерам. При этом в значительной степени высокий уровень общего финансового потенциала обеспечен благоприятными показателями по такому его элементу, как финансовый потенциал домашних хозяйств. По соотношению среднедушевого дохода к прожиточному минимуму регион находится на 3-м месте среди всех северных субъектов (выше только Ненецкий и ЯмалоНенецкий автономные округа). Такое соотношение обеспечивает высокий уровень сбережений населения и значительные темпы прироста финансовых активов населения. По остальным элементам финансового потенциала Магаданская обл. имеет средние значения индикаторов.

На севере с Магаданской обл. граничит третий по площади в России регион - Хабаровский край. Этот дальневосточный регион занимает лишь 36-е место по численности населения. Основная отрасль в структуре ВРП транспорт и связь. По территории края проходят Транссибирская и БайкалоАмурская железнодорожные магистрали. Также существенную долю занимают добыча полезных ископаемых и обрабатывающие производства. Основные отрасли специализации промышленности Хабаровского края - машиностроение и металлообработка, черная металлургия, лесная, деревообрабатывающая, целлюлозно-бумажная, горнодобывающая промышленность. По уровню ВРП на душу населения регион занимает соседнее с Иркутской обл. 20-е место, а по уровню социально-экономического положения - 31-е место.

По уровню финансового потенциала Хабаровский край ближе к концу рейтинга северных субъектов. Регион не имеет ярко выраженных сильных элементов финансового потенциала. Невысокий бюджетно-налоговый потенциал обусловлен дефицитностью бюджета региона (свыше $10 \%$ от объема расходных полномочий) и низким уровнем обеспеченности населения налоговыми платежами (около 72 тыс. руб. на чел.). Уровень среднедушевых доходов примерно соответствует среднероссийскому, но ниже, чем в Дальневосточном федеральном округе. Это не позволяет населению формировать высокие показатели сбережений и прироста финансовых активов. Невысокому значению потенциала хозяйствующих субъектов способствуют значительная доля убыточных предприятий и, как следствие, отрицательный сальдированный финансовый результат. Как практически для всех северных регионов, для Хабаровского края характерен низкий уровень развития финансово-кредитной сферы. 
Чукотский автономный округ - еще один субъект РФ, расположенный в Дальневосточном федеральном округе. Характеризуется существенной удаленностью от центральных регионов РФ и низкой численностью населения (около 50 тыс. чел.). В структуре хозяйства преобладает добыча полезных ископаемых, на которую приходится примерно 43 \% совокупного валового регионального продукта. Основу экономики составляет горнодобывающее производство.

В последние несколько лет бюджетно-налоговый потенциал региона существенно вырос. Это связано со значительным увеличением доходной части бюджета (с 2013 по 2016 гг. доходы выросли почти на 80 \%). В 2015-2016 гг. консолидированный бюджет округа исполнялся с профицитом. По объему бюджетных доходов на одного жителя Чукотский автономный округ является лидером среди всех субъектов РФ. С другой стороны, собственные доходы составляют лишь $55 \%$ от совокупной доходной базы региона, а по размеру отношения государственного долга к собственным доходам бюджета округ входит в первую десятку российских регионов.

Чукотский автономный округ имеет высокий финансовый потенциал домашних хозяйств, который обеспечен как значительным уровнем среднедушевых доходов населения (2015 г. - около 62 тыс. руб. в месяц), так и высоким значением его соотношения с прожиточным минимумом. Это позволяет формировать в регионе высокую склонность к сбережениям и большой прирост финансовых активов на человека. Однако же финансовый потенциал хозяйствующих субъектов региона можно оценить как недостаточный. Причиной этого является высокая доля убыточных организаций в округе и низкие значения финансовых вложений на одно предприятие.

Кредитно-финансовый потенциал Чукотского автономного округа может быть охарактеризован как умеренный. С одной стороны, регион обеспечен структурными подразделениями кредитных учреждений в расчете на одного жителя, с другой - объемы финансирования местных хозяйствующих субъектов и их инвестиционной деятельности недостаточны.

Мурманская обл. - арктический регион, расположенный в СевероЗападном федеральном округе РФ. Численность населения области чуть более 750 тыс. чел. Наибольшая доля валового регионального продукта региона приходится на добычу полезных ископаемых и обрабатывающие производства (примерно по 12,5 \%). Мурманская обл. - ярко выраженный промышленный субъект РФ, где развиты горнодобывающая, рыбная, химическая промышленность и цветная металлургия.

Регион характеризуется средним уровнем финансового потенциала, причем по всем составляющим финансового потенциала он имеет умеренные характеристики.

Бюджет Мурманской обл. дефицитен, но уровень дефицита составлял менее $3 \%$ от объема доходов в 2015 г. Доля собственных доходов бюджета достаточно высока - около 89 \%. По уровню обеспеченности населения налоговыми платежами регион значительно уступает ведущим по данному показателю арктическим субъектам РФ.

Уровень среднедушевых доходов населения Мурманской обл. в 2015 г. составлял около 37 тыс. руб. в месяц, но за счет высокого прожиточного минимума она не входит в число ведущих по коэффициенту сбережений 
населения и прироста финансовых активов. Также не способствует повышению финансового потенциала домашних хозяйств высокий уровень безработицы в регионе (в 2015 г. - 7,8 \%).

Если по показателям среднего уровня рентабельности хозяйствующих субъектов и объему инвестиций в основной капитал на одного жителя регион в рейтинге расположен достаточно высоко, то по показателям доли рентабельных организаций и объему произведенной продукции, товаров и услуг не входит в первую двадцатку субъектов РФ.

Мурманская обл. имеет несколько региональных кредитных организаций и широкую сеть филиалов столичных банков. Кредитные институты активно участвуют в финансировании инвестиционной деятельности предприятий и в формировании ресурсов за счет вкладов населения.

Еще одним арктическим субъектом РФ со средним финансовым потенциалом является Республика Коми. Она входит в состав Северо-Западного федерального округа и является частью Северного экономического района. В структуре валового регионального продукта округа около трети составляет добыча полезных ископаемых (нефть, газ, уголь, бокситы). Регион является одним из лидеров в России по производству бумаги, целлюлозы, фанеры. Республика Коми занимала 26-е место по итогам 2015 г. среди субъектов РФ в рейтинге социально-экономического развития агентства «Риарейтинг» [100].

Бюджет региона в последние годы сведен с дефицитом, в 2015 г. его размер составлял порядка $14 \%$ от совокупных доходов. При этом показатели доходов консолидированного бюджета региона на одного жителя (78,3 тыс. руб.) и доля собственных доходов бюджета (90 \%) достаточно высоки.

Финансовый потенциал домашних хозяйств Республики Коми ниже, чем в Ненецком, Чукотском и Ямало-Ненецком округах. При объеме среднедушевых доходов населения в 2015 г. 33,3 тыс. руб. в месяц уровень сбережений составляет порядка $37 \%$, что позволяет вовлекать в финансовую систему средства населения.

Республика Коми характеризуется умеренным потенциалом хозяйствующих субъектов. Здесь достаточно высоки показатель объема производства товаров и услуг в расчете на одного жителя (по данному показателю республика входит в десятку ведущих субъектов РФ) и уровень инвестиционной активности предприятий. При этом по уровню рентабельности хозяйствующих субъектов и доле неубыточных организаций республика заметно отстает от лидеров.

При оценке потенциала кредитно-финансовой сферы Республики Коми следует отметить, с одной стороны, наличие лишь одного регионального банка, невысокий объем привлеченных вкладов населения республики кредитными учреждениями, с другой стороны, достаточно высокий уровень привлеченных источников (за исключением бюджетных средств) в структуре финансирования инвестиционных проектов.

Архангельская обл. - крупнейший субъект РФ в европейской части России (по площади превышает территорию Франции и Испании). Регион, как и два рассмотренных выше, тоже входит в состав Северо-Западного федерального округа. В Архангельской обл. нет определенного вида экономической деятельности, который в существенной степени формировал бы региональное хозяйство. Наибольшую долю в структуре производимого валового регионального продукта занимает добыча полезных ископаемых (около 27 \%), обрабатывающие 
производства, транспорт и связь (доля данных отраслей находится на уровне $13 \%$ ), торговля. Среди отраслей специализации региона нужно отметить целлюлозно-бумажную промышленность (на долю области приходится треть производящегося в стране картона, четверть - целлюлозы, значительная часть необработанной древесины).

Бюджет Архангельской обл. в последние годы остается дефицитным (уровень дефицита бюджета составляет порядка $5 \%$ от совокупного объема доходов). Доля собственных доходов составляет около четверти от совокупного объема. По показателю поступлений налоговых платежей на одного человека (в 2015 г. порядка 54 тыс. руб.) регион также не входит в лидирующую группу субъектов РФ.

Низкое значение коэффициента соотношения среднедушевых доходов к прожиточному минимуму и высокая доля населения с денежными доходами ниже прожиточного минимума не позволяют формировать Архангельской обл. высокий финансовый потенциал домашних хозяйств.

В последние годы в области растет финансовый потенциал хозяйствующих субъектов: наблюдается увеличение средних показателей рентабельности активов (2015 г. - 2,8 \%), рентабельности реализованной продукции, товаров, услуг (2015 г. - 10,4 \%), сальдированный финансовый результат деятельности организаций после отрицательных значений в 2011-2014 гг. вышел в положительную зону. При этом потенциал финансово-кредитной сферы может быть охарактеризован как достаточно низкий: в области отсутствуют региональные кредитные организации, количество филиалов банков из других регионов в последние 10 лет снизилось более чем в 2 раза, отношение объема вкладов в кредитные организации к ВРП и доля кредитных средств в структуре инвестиций невысоки.

Ненеикий автономный округ - самый малонаселенный субъект РФ. Входит в состав Северо-Западного федерального округа. Особенность административного статуса округа заключается в том, что он одновременно является самостоятельным субъектом РФ и входит в состав Архангельской обл. В структуре хозяйства Ненецкого автономного округа преобладающими видами экономической деятельности является добыча полезных ископаемых, на которую приходится около $75 \%$ от валового регионального продукта, т. е. округ может быть отнесен к сырьевым субъектам нашей страны.

По финансовому потенциалу Ненецкий автономный округ может быть отнесен к группе регионов со средним финансовым потенциалом. Данный субъект, с одной стороны, имеет дефицитный консолидированный бюджет (дефицит в 2016 г. составил, по предварительной оценке, около $15 \%$ от объема доходов), с другой стороны, является одним из лидеров в России по объему обеспеченности населения налоговыми платежами.

Высокой оценки заслуживает финансовый потенциал домашних хозяйств региона. В основном он обеспечен высокими ежемесячными среднедушевыми доходами населения, которые в 2015 г. составляли около 71 тыс. руб. на человека, и высокой склонностью к сбережениям (об этом, в частности, свидетельствуют высокие значения коэффициента, характеризующего отношение сбережений домашних хозяйств, и прироста финансовых активов у населения).

Тем не менее показатели потенциала хозяйствующих субъектов и потенциала кредитно-финансовой сферы региона невысоки. В Ненецком автономном округе низкие показатели средней рентабельности хозяйствующих 
субъектов, высокая доля убыточных предприятий, не развита региональная сеть кредитных учреждений, доступность заемного капитала для субъектов бизнеса может быть оценена как низкая.

Республика Карелия - наименее финансово обеспеченный регион Северо-Западного федерального округа. По уровню ВРП на душу населения субъект находится в четвертом десятке общероссийского рейтинга. Регион имеет достаточно диверсифицированную структуру хозяйства. Промышленность Карелии специализируется на добыче полезных ископаемых, лесозаготовительной, деревообрабатывающей и целлюлозно-бумажной отраслях.

Уровень финансового потенциала Республики Карелия можно охарактеризовать как низкий, при этом в последние годы он имел тенденцию к сокращению. По всем элементам финансового потенциала средние значения индикаторов ниже как средних показателей по северным регионам, так и среднероссийских. Республика Карелия имеет наиболее низкие значения показателей бюджетно-налогового потенциала (в связи с большим размером дефицита регионального бюджета и низкой обеспеченностью населения налоговыми платежами) и финансового потенциала хозяйствующих субъектов (низкие значения сальдированного финансового результата, высокая доля убыточных хозяйствующих субъектов). Несмотря на северную специфику, регион отстает и по уровню среднедушевых доходов населения, что не позволяет сформировать достаточную базу сбережений, которую можно было бы использовать для обеспечения развития и реализации инвестиционных проектов.

\section{2. Ранжирование и группировка регионов Крайнего Севера по интегральному показателю финансового потенциала}

Расчет финансового потенциала конкретного северного региона как интегрального индикатора, оценивающего способность региона к формированию собственной ресурсной базы, обеспечивающей развитие территории, осуществляется методом соединения компонентов (индикаторов), характеризующих бюджетно-налоговый потенциал, потенциалы хозяйствующих субъектов, домашних хозяйств, финансово-кредитной сферы региона. Полученная оценка финансового потенциала региона является обоснованным отражением качества системы регионального финансового управления. На основе количественной характеристики финансового потенциала можно проводить группировку регионов с целью выявления наиболее финансово сильных при построении системы или оценки результатов межбюджетных расчетов. Учет группы, занимаемой регионом по уровню финансового потенциала, позволяет региональным властям повысить эффективность и результативность проводимой региональной финансовой политики, служит основой при разработке стратегии развития регионов Севера Российской Федерации.

В соответствии с авторской методикой (см. главу 1) при оценке финансового потенциала необходимо выделять следующие составляющие его элементы:

- бюджетно-налоговый потенциал, расчет которого основан на таких показателях, как общий объем бюджетных доходов и расходов региона, сумма собственных доходов, величина трансфертов; 
- потенциал домохозяйств, расчет которого основан на таких показателях, как доходы физических лиц, проживающих на территории региона, доля сбережений и потребления в структуре доходов, а также величина прожиточного минимума в регионе;

- потенциал хозяйствующих субъектов, расчет которого основан на таких показателях, как сальдированный финансовый результат хозяйствующих субъектов, объем амортизационных отчислений, рентабельность хозяйствующих субъектов, доля неубыточных предприятий;

- потенциал финансово-кредитной сферы, расчет которого основан на определении инвестиционных возможностей экономических субъектов региона, уровня развития финансовой инфраструктуры, а также основных показателей банковской системы.

Выделение отдельных элементов финансового потенциала позволяет провести интегральную количественную оценку его состояния на основании применения статистических методов и приемов.

Для расчета интегрального итогового показателя финансового потенциала субъекта РФ может быть применен следующий алгоритм:

1. Расчет отдельных показателей, характеризующих элементы финансового потенциала региона: бюджетно-налоговый потенциал, потенциал домохозяйств, потенциал хозяйствующих субъектов, потенциал финансовокредитной сферы.

2. Определение процентного отклонения от среднероссийского значения по каждому (j-му) относительному показателю $\left(\Delta \operatorname{lotн}_{i}^{j}\right)$, характеризующему финансовый потенциал, для каждого $i$-го северного региона.

3. Рассчитывается отношение процентного отклонения по каждому относительному показателю $\left(\Delta \operatorname{loth}_{i}^{j}\right)$ к среднеквадратическому отклонению по соответствующему $j$-му относительному показателю потенциала $\left(\sigma_{j}\right)$ :

$$
r=\frac{\Delta \operatorname{IoTH}_{i}^{j}}{\sigma_{i}} .
$$

В связи с тем, что между величиной показателя «отношение дефицита консолидированного бюджета к величине расходов» и уровнем финансового потенциала региона наблюдается обратная зависимость, для данного показателя используем формулу

$$
r=\frac{-\Delta \text { Іотн }_{i}^{j}}{\sigma_{j}} .
$$

Данный этап расчетов необходим для устранения влияния диапазона колебания по отдельным относительным показателям, т. е. для приведения значений отклонения показателей от среднероссийских значений в сопоставимый вид.

4. Присваиваются баллы по каждому $j$-му показателю каждому $i$-му региону. Для этого используется пятибалльная шкала оценок (наибольшая оценка соответствует максимально благоприятному значению показателя, наименьшая максимально неблагоприятному значению). Для этого рассчитаем 1/6 часть 
среднего размаха среди всех 16 показателей $r$ (отношение процентного отклонения по каждому относительному показателю к среднеквадратическому отклонению по соответствующему $j$-му относительному показателю потенциала):

$$
d=1 / 6 \frac{\sum_{i=1}^{16}\left(r \max _{j}-r \min _{j}\right)}{16},
$$

где $r \max _{j}$ и $r \min _{j}$ - максимальное и минимальное значения соответствующего показателя $r$.

5. Определяются баллы, которые соответствуют каждому показателю, характеризующему отдельные элементы финансового потенциала (для показателей $j=1 \ldots 16)$ и для каждого региона, с помощью формулы

$$
b_{i}^{j}=\frac{r_{j}^{i}}{d}+3 .
$$

В связи с большим массивом расчетных показателей в данной монографии промежуточные расчеты не приводятся. Исходные абсолютные значения показателей, рассчитанные относительные коэффициенты по каждому элементу финансового потенциала и балльная оценка каждого показателя для северных регионов авторами приводятся в зарегистрированной базе данных [101].

Показатели оценки отдельных элементов финансового потенциала регионов Крайнего Севера и итоговая балльная оценка за 2015 г. представлены в табл. 16.

Проведем общую группировку северных регионов в соответствии с полученными результатами. В качестве медианного значения построения группировки показателей используем сумму для среднероссийского уровня. Так как при нормировании показателей мы использовали сравнение значений со среднероссийскими, то баллы, которые соответствуют каждому показателю, характеризующему отдельные элементы финансового потенциала (для показателей $j=1 \ldots 16)$, будут равны:

$$
b_{j}=(0 / d)+3=3 \text {. }
$$

Средние баллы, согласно расчетам, составят:

- бюджетно-налоговый потенциал $=3 \cdot 4=12$;

- потенциал домашних хозяйств $=3 \cdot 4=12$;

- потенциал хозяйствующих субъектов $=3 \cdot 4=12$;

- потенциал финансово-кредитной сферы $=3 \cdot 4=12$;

Тогда значение совокупного среднероссийского показателя при группировке составит:

$$
12,0+12,0+12,0+12,0=48 \text { баллов. }
$$

В качестве диапазона группы регионов, характеризующихся финансовым потенциалом, близким к среднероссийскому уровню, примем отклонение, равное балльной оценке, которая соответствует значению показателя, отражающему отдельные элементы финансового потенциала для среднероссийского уровня (3 балла). Диапазон значений: от 45 до 51 балла. 
Оценка финансового потенциала и его составляющих регионов Крайнего Севера за 2015 г.

\begin{tabular}{|c|c|c|c|c|c|}
\hline \multirow[b]{2}{*}{ Регион } & \multicolumn{4}{|c|}{ Финансовый потенциал } & \multirow[b]{2}{*}{ Всего } \\
\hline & бюджетно-налоговый & домашних хозяйств & хозяйствующих субъектов & $\begin{array}{c}\text { кредитно- } \\
\text { финансовый }\end{array}$ & \\
\hline Ямало-Ненецкий АО & 16,8 & 19,2 & 9,7 & 13,4 & 59,2 \\
\hline Чукотский АО & 11,6 & 20,7 & 16,2 & 8,9 & 57,3 \\
\hline Ханты-Мансийский АО & 16,6 & 13,5 & 20,7 & 6,1 & 56,9 \\
\hline Ненецкий АО & 14,7 & 20,7 & 11 & 10,4 & 56,8 \\
\hline Сахалинская обл. & 15,8 & 14,2 & 12,2 & 9 & 51,3 \\
\hline Магаданская обл. & 8,3 & 14,8 & 12,1 & 13,8 & 48,9 \\
\hline Мурманская обл. & 12,6 & 12 & 12,3 & 9,3 & 46,2 \\
\hline Республика Саха (Якутия) & 10,4 & 11,1 & 14,2 & 9,7 & 45,5 \\
\hline Красноярский край & 11,2 & 10,5 & 13,7 & 10 & 45,3 \\
\hline Республика Коми & 11,3 & 12,3 & 12,5 & 8,4 & 44,5 \\
\hline Иркутская обл. & 11,1 & 10,9 & 14,7 & 7,5 & 44,2 \\
\hline Хабаровский край & 10,4 & 11,4 & 8,9 & 12,5 & 43,2 \\
\hline Архангельская обл. & 11 & 10,9 & 10,4 & 9,7 & 42,1 \\
\hline Камчатский край & 8,1 & 12,5 & 11 & 9,7 & 41,4 \\
\hline Республика Карелия & 9,4 & 10,1 & 8 & 8,7 & 36,2 \\
\hline Республика Тыва & 5,8 & 8,4 & 7,2 & 8,7 & 30,1 \\
\hline
\end{tabular}


Таким образом, к регионам с высоким финансовым потенциалом будут относиться субъекты РФ, значение интегральных показателей финансового потенциала которых больше 51 балла.

Учитывая специфику северных субъектов РФ, в качестве нижней границы группы регионов со средним финансовым потенциалом примем уровень, отличающийся от среднероссийского значения на $200 \%$ балльной оценки, соответствующей значению показателя, характеризующему отдельные элементы финансового потенциала для среднероссийского уровня (6 баллов) -42 балла.

Субъекты РФ, значения интегральных показателей которых меньше 42 баллов, отнесем к регионам с низким финансовым потенциалом.

Группировка северных регионов в соответствии с полученной количественной оценкой финансового потенциала представлена в табл. 17.

Таблица 17

Группировка северных регионов

в соответствии с полученной количественной оценкой финансового потенциала

\begin{tabular}{|c|c|c|}
\hline $\begin{array}{c}\text { Уровень } \\
\text { финансового потенциала }\end{array}$ & Баллы & Регионы Крайнего Севера \\
\hline 1. Низкий & $\leq 42$ & $\begin{array}{l}\text { Камчатский край; } \\
\text { Республика Карелия; } \\
\text { Республика Тыва }\end{array}$ \\
\hline 2. Средний & $42-51$ & \\
\hline $\begin{array}{l}\text { 2.1. Средний (близкий } \\
\text { к среднероссийскому) }\end{array}$ & $45-51$ & $\begin{array}{l}\text { Мурманская обл.; } \\
\text { Республлика Саха (Якутия); } \\
\text { Красноярский край }\end{array}$ \\
\hline $\begin{array}{l}\text { 2.2. Средний (близкий } \\
\text { к низкому) }\end{array}$ & $42-45$ & $\begin{array}{l}\text { Республика Коми; } \\
\text { Иркутская обл.; } \\
\text { Хабаровский край; } \\
\text { Архангельская обл. }\end{array}$ \\
\hline $\begin{array}{l}\text { 3. Высокий (или близкий } \\
\text { к высокому) за счет } \\
\text { значительного финансового } \\
\text { потенциала домашних } \\
\text { хозяйств }\end{array}$ & $\begin{array}{c}\text { 45-54 } \\
\text { (потенциал домашних } \\
\text { хозяйств более 14) }\end{array}$ & $\begin{array}{l}\text { Чукотский АО; } \\
\text { Ненецкий АО; } \\
\text { Магаданская обл. }\end{array}$ \\
\hline 4. Высокий & $\geq 51$ & $\begin{array}{l}\text { Ямало-Ненецкий АО; } \\
\text { Ханты-Мансийский АО; } \\
\text { Сахалинская обл. }\end{array}$ \\
\hline
\end{tabular}

В табл. 18 приведены регионы-лидеры исследуемой группы по каждому элементу финансового потенциала.

Остановимся более подробно на характеристике регионов, вошедших в каждую группу.

К группе северных регионов с низким финансовым потенциалом были отнесены Республика Карелия, Республика Тыва, Камчатский край (рис. 13). 
Регионы-лидеры среди северных регионов по каждому элементу финансового потенциала (с балльной оценкой по выделенному элементу более 14) (по данным 2015 г.)

\begin{tabular}{|c|c|c|c|}
\hline $\begin{array}{l}\text { Бюджетно- } \\
\text { налоговый } \\
\text { потенциал }\end{array}$ & $\begin{array}{c}\text { Потенциал } \\
\text { домашних хозяйств }\end{array}$ & $\begin{array}{c}\text { Потенциал } \\
\text { хозяйствующих } \\
\text { субъектов }\end{array}$ & $\begin{array}{c}\text { Кредитно- } \\
\text { финансовый } \\
\text { потенциал }\end{array}$ \\
\hline $\begin{array}{l}\text { Ямало-Ненецкий АО } \\
\text { Ханты-Мансийский } \\
\text { АО } \\
\text { Сахалинская обл. } \\
\text { Ненецкий АО }\end{array}$ & $\begin{array}{l}\text { Ненецкий АО } \\
\text { Чукотский АО } \\
\text { Сахалинская обл. } \\
\text { Магаданская обл. } \\
\text { Ямало-Ненецкий АО }\end{array}$ & $\begin{array}{l}\text { Ханты-Мансийский } \\
\text { АО } \\
\text { Республика Саха } \\
\text { (Якутия) } \\
\text { Иркутская обл. } \\
\text { Чукотский АО }\end{array}$ & 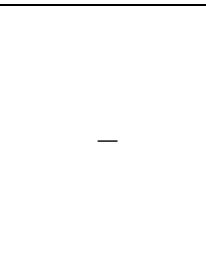 \\
\hline
\end{tabular}
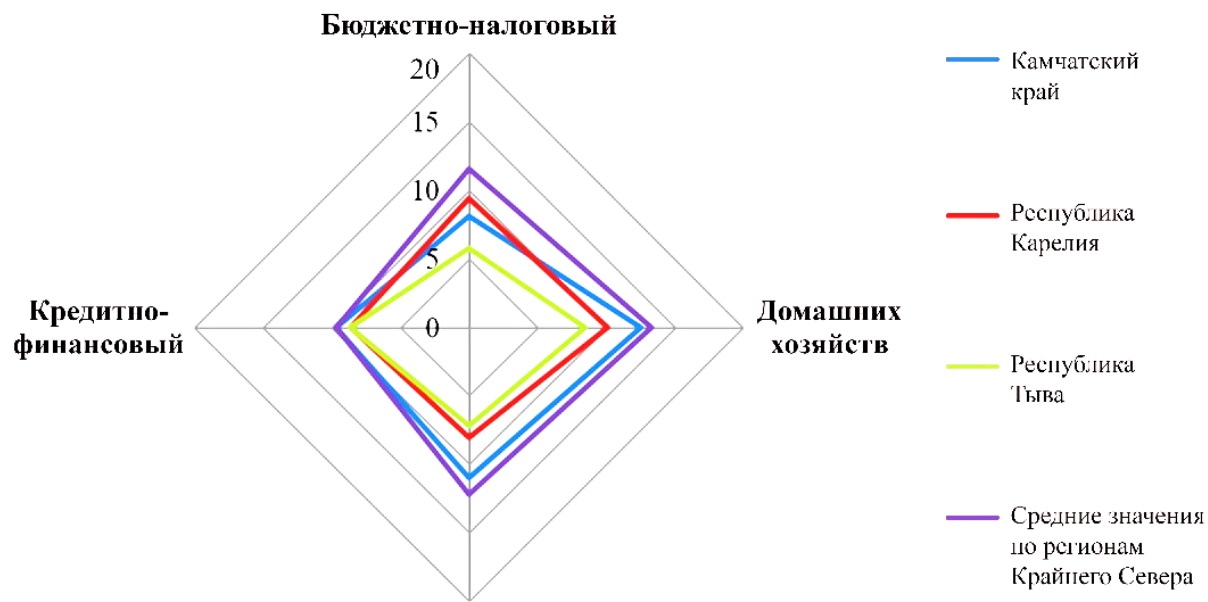

Хозяйствуюших субъектов

Рис. 13. Оценка элементов группы северных регионов с низким финансовым потенциалом

Все регионы данной группы характеризуются низким бюджетноналоговым потенциалом. Причиной этого являются низкая доля собственных доходов в региональных бюджетах и высокий уровень дефицитности бюджетов (наиболее проблемным представляется бюджет Республики Тыва).

Потенциал домашних хозяйств данной группы регионов тоже характеризуется низкими значениями (за исключением Камчатского края). Причина, прежде всего, в низком уровне среднедушевых доходов по отношению к прожиточному минимуму и высокой численности населения с денежными доходами ниже прожиточного минимума. Следует отметить, что Камчатский 
край получил более высокую оценку по потенциалу домашних хозяйств, прежде всего, за счет высокой склонности к сбережениям (у населения данного региона, несмотря на низкое соотношение среднедушевых доходов и прожиточного минимума, есть возможность откладывать и иметь финансовые активы за счет высокого уровня средней заработной платы).

Регионы с низким финансовым потенциалом характеризуются различными показателями хозяйствующих субъектов. Если предприятия и организации таких субъектов, как Республика Тыва, Камчатский край, практически не способны формировать финансовые ресурсы, то рентабельность реализации продукции (услуг, работ) в Республике Карелия находится на приемлемом уровне.

Кредитно-финансовые рынки регионов первой группы в целом могут быть охарактеризованы как неразвитые. Исключение составляют Камчатский край, где высока обеспеченность населения структурными подразделениями кредитных учреждений.

Наибольшее число северных регионов следует отнести к группе со средним финансовым потенциалом, при этом в данной группе было выделено две подгруппы.

К первой подгруппе были отнесены Архангельская и Иркутская обл., Республика Коми и Хабаровский край. Данные регионы имеют количественную оценку финансового потенциала на уровне 42-45 баллов (рис. 14).
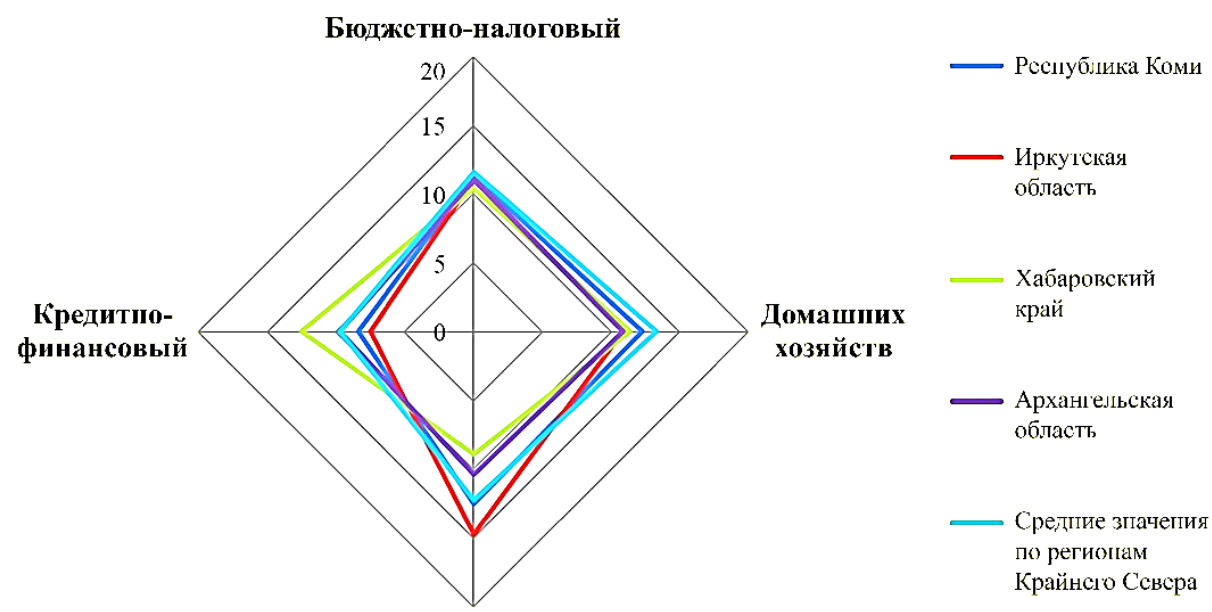

Хозяйствующих субъектов

Рис. 14. Оценка элементов группы северных регионов со средним (близким к низкому) финансовым потенциалом

У регионов данной группы средние или близкие к средним показатели бюджетно-налогового потенциала. 
Количественная оценка финансового потенциала домашних хозяйств по регионам данной подгруппы находится на уровне 10-11 баллов, что также соответствует среднему диапазону значений (за исключением Архангельской обл., где отношение среднедушевого дохода в регионе к прожиточному минимуму меньше, чем в среднем по России, на $26 \%$ ).

По потенциалу хозяйствующих субъектов наиболее слабые позиции среди регионов данной подгруппы занимает Хабаровский край, где значительна доля убыточных предприятий и организаций, а средние финансовые вложения хозяйствующих субъектов незначительны.

По потенциалу финансово-кредитной сферы слабые позиции имеет Республика Коми (низкая активность банковского сектора в кредитовании реального сектора экономики региона).

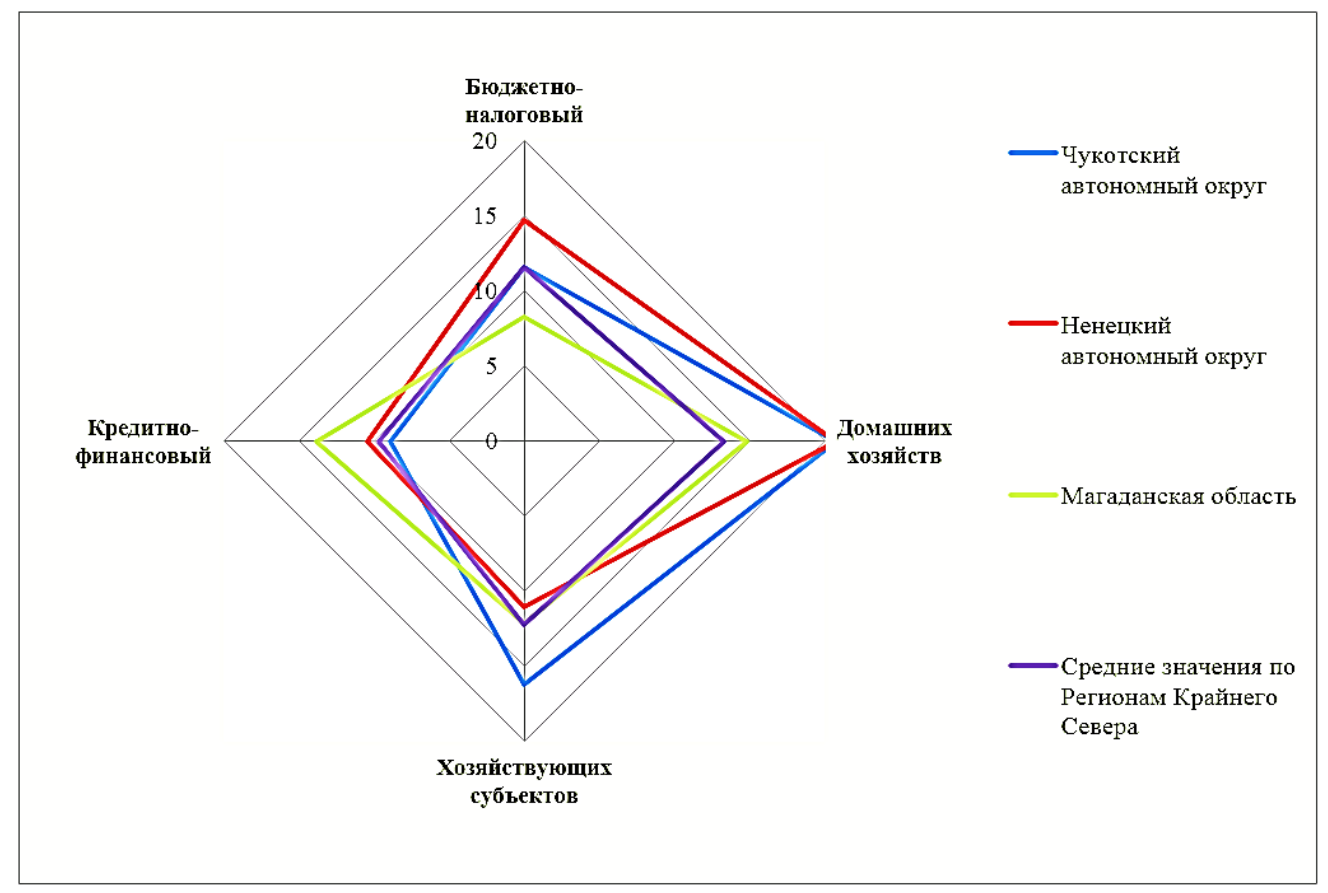

Рис. 15. Оценка элементов группы северных регионов, имеющих высокие или близкие к высокому значения финансового потенциала, прежде всего за счет потенциала домохозяйств

Среди северных регионов можно выделить отдельную группу субъектов Российской Федерации, это Чукотский и Ненецкий автономные округа, Магаданская обл. (рис. 15). Они характеризуются достаточно высокой суммой набранных баллов (первые два региона по количеству баллов входят в число субъектов с высоким финансовым потенциалом), но при этом в основном их сумма была обеспечена высокими баллами по такой составляющей совокупного финансового потенциала, как финансовый потенциал домохозяйств (доля данного элемента в структуре баллов для Чукотского и Ненецкого автономных округов 36-37 \%, для Магаданской обл. - 30 \%). Высокий уровень среднедушевых доходов позволяет обеспечивать в этих регионах благоприятные показатели 
формирования сбережений населения и прироста финансовых активов. Однако говорить о значительном абсолютном финансовом потенциале домохозяйств данных регионов не представляется возможным в связи с низкой численностью населения данных субъектов (совокупная численность населения выделенных трех регионов составляет порядка 240 тыс. чел.).

По уровню оценки других составляющих финансового потенциала данные регионы различаются. Так, Ненецкий автономный округ за счет высокой обеспеченности населения налоговыми платежами имеет значительный бюджетно-налоговый потенциал и низкие значения потенциала хозяйствующих субъектов (в регионе низкая средняя рентабельность и высокая удельная доля нерентабельных организаций) и финансово-кредитной сферы (низкая активность банков в области кредитования реального сектора и привлечения средств организаций и населения).

В Магаданской обл. при низком уровне бюджетно-налогового потенциала (в регионе низкая доля собственных бюджетных доходов, а дефицит консолидированного бюджета превышает среднероссийские показатели) и потенциала хозяйствующих субъектов (доля убыточных организаций более 40 \%) достаточно сильно развита финансово-кредитная сфера (характеризуется высокой обеспеченностью населения и хозяйствующих субъектов кредитными учреждениями, значительна доля привлеченного и заемного финансирования в структуре инвестиций).

В Чукотском автономном округе при средних количественных оценках финансового потенциала хозяйствующих субъектов и финансово-кредитной сферы наблюдается низкий уровень бюджетно-налогового потенциала, обусловленный, прежде всего, чрезвычайно низким уровнем концентрации собственных бюджетных доходов (собственные доходы бюджета составляют около $50 \%$ от объема бюджетных расходов региона).

Еще в одну подгруппу регионов со средним финансовым потенциалом (близким к среднероссийскому уровню) были выделены Мурманская обл., Красноярский край, Республика Саха (рис. 16).

Отличительной чертой регионов, вошедших в данную подгруппу, является то, что при невысоких уровнях бюджетно-налогового потенциала, потенциала домашних хозяйств и потенциала финансово-кредитной сферы, перечисленные субъекты РФ характеризуются высокой количественной оценкой потенциала хозяйствующих субъектов (здесь высоки средняя рентабельность реализации продукции (товаров, услуг) и уровень сальдированного финансового результата за счет наличия эффективных крупных промышленных предприятий).

Среди северных регионов можно выделить три субъекта РФ с высоким финансовым потенциалом. Это Ямало-Ненецкий и Ханты-Мансийский автономные округа, Сахалинская обл. (рис. 17). Все они характеризуются достаточно высоким уровнем бюджетно-налогового потенциала. В этих регионах профицитные консолидированные бюджеты, два из них имеют показатель отношения поступлений налогов в регионе на душу населения, превосходящий среднероссийское значение в более чем 10 раз (Ямало-Ненецкий и ХантыМансийский автономные округа).

Для Сахалинской обл. и Ямало-Ненецкого автономного округа характерны высокие оценки потенциала домашних хозяйств за счет одновременного сочетания высоких среднедушевых доходов и высокой склонности к сбережениям населения. 

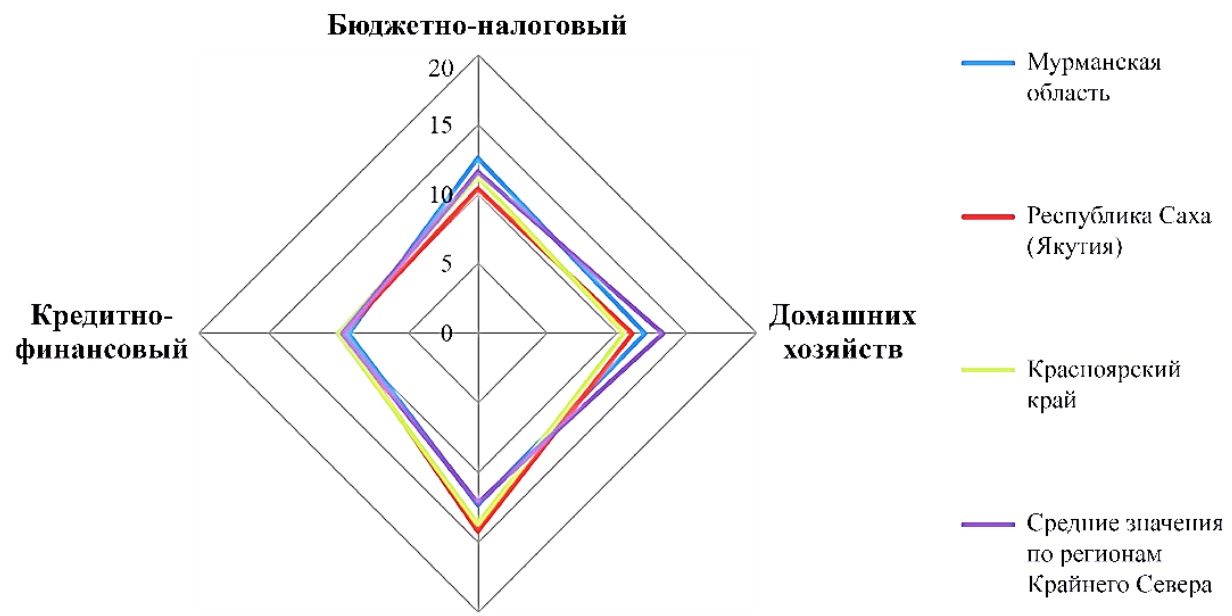

Хозяйствующих субъьектов

Рис. 16. Оценка элементов группы северных регионов, имеющих средние (близкие к среднероссийскому уровню) значения финансового потенциала, прежде всего за счет потенциала домохозяйств

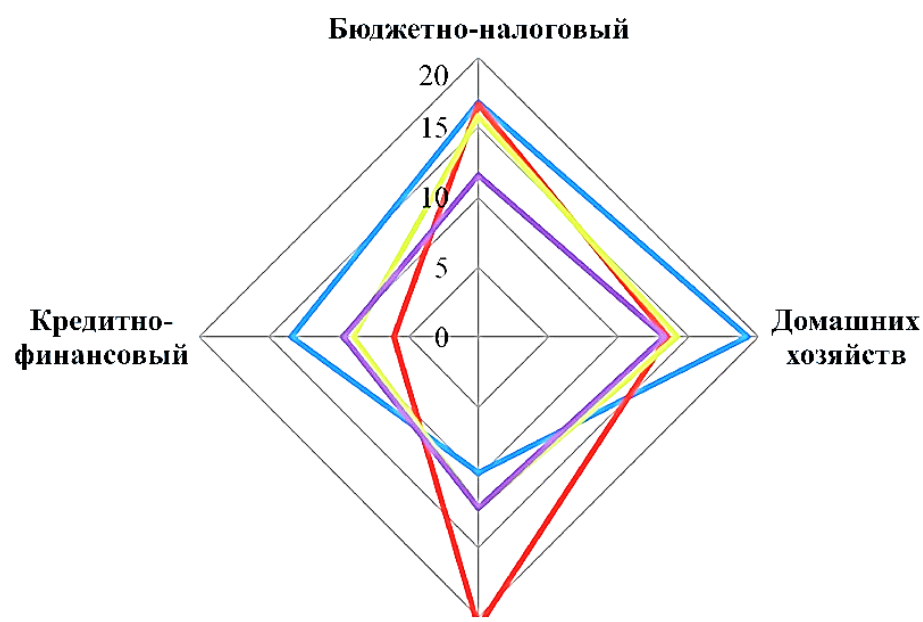
— Ямало-Нснсцкий автономный округ
— Ханты-Мансийский автономный округ
- Сахалинская область
Средние значения но регионам Крайтего Севера

Хозяйствующих субъектов

Рис. 17. Оценка элементов группы северных регионов с высоким финансовым потенциалом 
Наиболее сильной стороной финансового потенциала ХантыМансийского автономного округа является потенциал хозяйствующих субъектов. В этом регионе существенно выше среднероссийских значений показатели сальдированного финансового результата, финансовых вложений на одно предприятие и организацию, средней рентабельности проданных товаров, продукции, работ, услуг.

Динамика значений итоговой балльной оценки совокупного финансового потенциала регионов Крайнего Севера в соответствии с полученной количественной оценкой финансового потенциала представлена в табл. 19.

Таблиия 19

Значения итоговой балльной оценки совокупного финансового потенциала регионов Крайнего Севера в 2005, 2010 и 2015 гг.

\begin{tabular}{|c|l|c|c|c|}
\hline $\begin{array}{c}\text { № } \\
\text { п/п }\end{array}$ & \multicolumn{1}{|c|}{ Регион } & 2005 г. & 2010 г. & 2015 г. \\
\hline 1 & Ямало-Ненецкий АО & $\mathbf{6 1 , 4}$ & $\mathbf{6 2 , 5}$ & $\mathbf{5 9 , 2}$ \\
\hline 2 & Чукотский АО & $\mathbf{6 3 , 1}$ & $\mathbf{5 1 , 9}$ & $\mathbf{5 7 , 3}$ \\
\hline 3 & Ханты-Мансийский АО & $\mathbf{6 6 , 2}$ & $\mathbf{5 4 , 3}$ & $\mathbf{5 6 , 9}$ \\
\hline 4 & Ненецкий АО & $\mathbf{6 6 , 2}$ & $\mathbf{6 2 , 3}$ & $\mathbf{5 6 , 8}$ \\
\hline 5 & Сахалинская обл. & 47,3 & 40,6 & $\mathbf{5 1 , 3}$ \\
\hline 6 & Магаданская обл. & 48,2 & 49,1 & 48,9 \\
\hline 7 & Мурманская обл. & 46,6 & 48,8 & 46,2 \\
\hline 8 & Республика Саха (Якутия) & 46,2 & 43,1 & 45,5 \\
\hline 9 & Красноярский край & 47,2 & 47,5 & 45,3 \\
\hline 10 & Республика Коми & 49,4 & 48,1 & 44,5 \\
\hline 11 & Иркутская обл. & 42,7 & 45,1 & 44,2 \\
\hline 12 & Хабаровский край & 45,3 & 45,4 & 43,2 \\
\hline 13 & Архангельская обл. & 45,8 & 42,3 & 42,1 \\
\hline 14 & Камчатский край & 43,7 & 43,6 & 41,4 \\
\hline 15 & Республика Карелия & 44,4 & 40,6 & 36,2 \\
\hline 16 & Республика Тыва & 26,4 & 33,5 & 30,1 \\
\hline
\end{tabular}

* Полужирным выделены значения, попадающие в диапазон высокого финансового потенциала территорий; курсивом - значения, попадающие в диапазон низкого финансового потенциала.

Следует отметить, что рассчитанные баллы характеризуют не динамику абсолютной величины финансового потенциала, а только изменение положения региона относительно среднероссийских значений, то есть повышение оценки финансового потенциала свидетельствует о более высоких темпах развития потенциальной финансовой базы региона по сравнению со средними уровнями по РФ, снижение оценки формирует обратную тенденцию.

Согласно рассчитанным показателям можно сделать следующие выводы.

В целом в большинстве регионов за анализируемое десятилетие наблюдается снижение количественных характеристик финансового потенциала относительно среднероссийских значений. Так, в 12 регионах из 16 совокупная 
балльная оценка финансового потенциала снизилась и лишь в 4 (Магаданская, Сахалинская и Иркутская обл., Республика Тыва) выросла. Также об этом свидетельствует снижение средней балльной оценки с 49,4 балла в 2005 г. до 46,8 балла в 2015 г.

Достаточно интересна динамика оценки отдельных составляющих финансового потенциала, которая представлена на рис. 18.

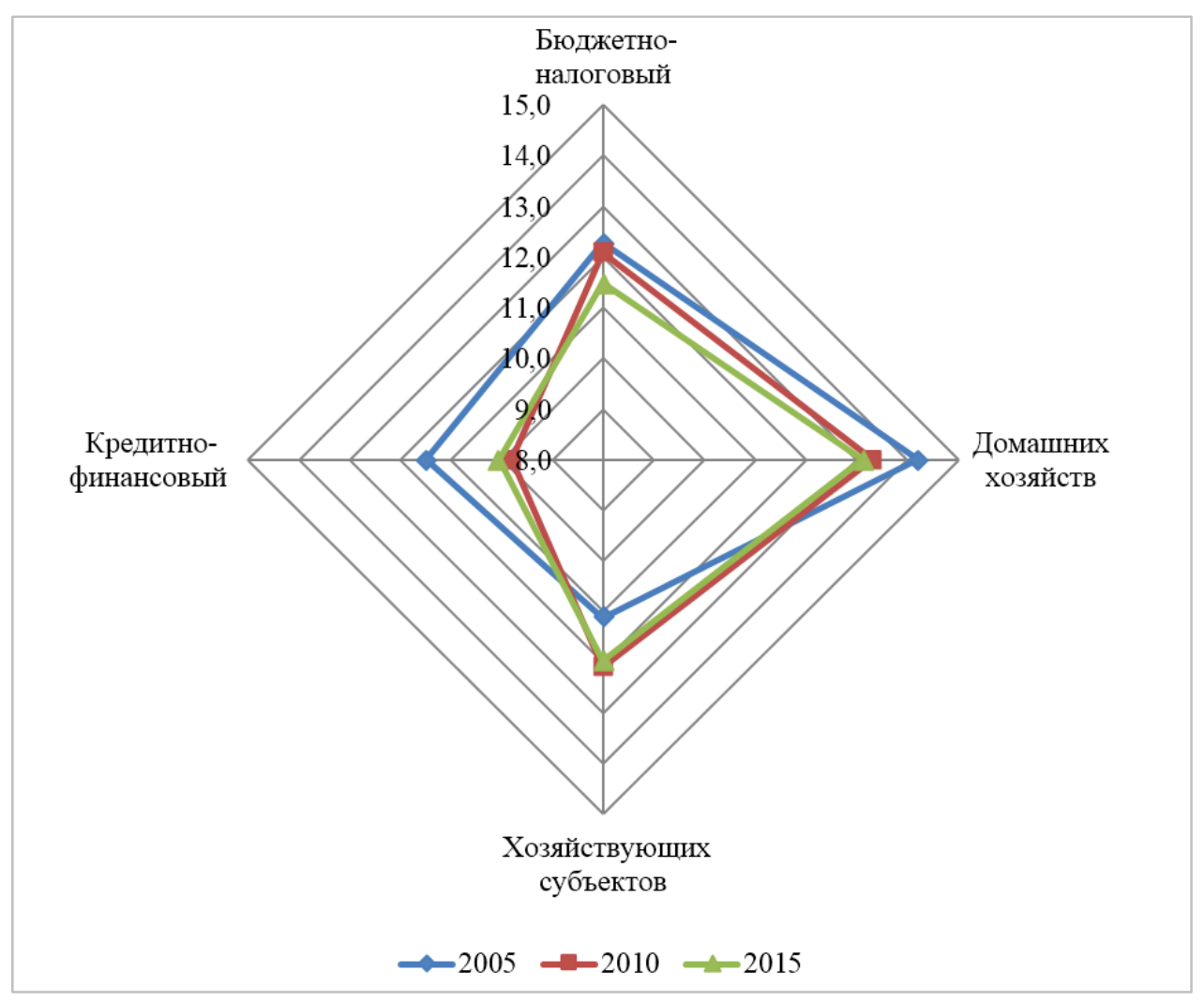

Рис. 18. Динамика оценки отдельных составляющих финансового потенциала регионов Крайнего Севера

Приведенные данные свидетельствуют о снижении в последнее десятилетие средних показателей оценки бюджетно-налогового, кредитнофинансового потенциалов и потенциала домашних хозяйств при росте значений потенциала хозяйствующих субъектов, т. е. в целом в регионах Крайнего Севера наблюдается достаточно отчетливая тенденция оттока финансовых ресурсов, формируемых хозяйствующими субъектами, в большинстве своем представленными крупными промышленными предприятиями, работающими в области добычи и переработки полезных ископаемых данных территорий. Ведущие промышленные предприятия, показывая высокие значения финансовых результатов (прибыли, рентабельности), не обеспечивают пропорционального наполнения региональных бюджетов и роста благосостояния населения, проживающего в данных субъектах. Перерегистрация многих крупных хозяйствующих субъектов в Москве и СанктПетербурге привела к снижению налоговых поступлений в региональные 
бюджеты, что в условиях специфики многих северных регионов (промышленный характер экономики, базирующийся на отрасли «добыча полезных ископаемых») уменьшило формируемую для экономического развития финансовую базу.

В стагнации находятся и кредитно-финансовые системы рассматриваемой группы субъектов РФ. Во многом этому способствуют ограниченные полномочия региональных органов власти в области применения монетарных рычагов регулирования, сокращение числа региональных кредитных структур (прежде всего, региональных банков), чья деятельность во многом определяется интересами региональных органов власти.

Согласно примененной методике оценки финансового потенциала, среднероссийский уровень по всем элементам финансового потенциала в течение всего анализируемого периода является неизменным и составляет 12 баллов. Сопоставление с данным уровнем средних значений оценок отдельных элементов финансового потенциала северных субъектов РФ показал, что рассматриваемая группа регионов характеризуется в целом высоким уровнем финансового потенциала домохозяйств, сопоставимыми уровнями бюджетно-налогового потенциала и потенциала хозяйствующих субъектов и слабыми значениями потенциала кредитно-финансовой сферы.

Графическая интерпретация ранжирования северных регионов на основе количественной характеристики финансового потенциала дана на рис. 19.

Количественное наполнение групп на протяжении трех анализируемых периодов достаточно сильно изменяется, при этом 13 из 16 регионов на протяжении всего периода сохраняют принадлежность к определенной группе и лишь 3 переходят в другую категорию. Число регионов, характеризуемых как обладающие высоким финансовым потенциалом, в 2010 г. увеличилось с 2 до 3, сохранив это значение в 2015 г. Следует отметить, что в 2010 г. в число субъектов с высоким финансовым потенциалом вошла Сахалинская обл.

Характерным моментом полученной рейтинговой оценки является территориальное расположение субъектов РФ с наихудшими оценками финансового потенциала.

Субъект с наименьшей оценкой финансового потенциала - Республика Тыва - находится в Забайкалье. Регионы, территориально расположенные рядом c Тывой (Республика Бурятия, Забайкальский край, Республика Алтай), не относятся к регионам Крайнего Севера, но по законодательству имеют статус приравненным к ним, характеризуются схожей спецификой хозяйства и также низким уровнем финансового потенциала. Несмотря на то, что эти регионы богаты полезными ископаемыми, имеют значительные природно-рекреационные ресурсы, они характеризуются слабой инвестиционной привлекательностью, отсутствием крупных промышленных кластеров и низким уровнем жизни. В настоящий момент действует Стратегия социально-экономического развития Дальнего Востока и Байкальского региона на период до 2025 года [102], которая подразумевает реализацию мер, направленных на развитие восточных регионов, но на практике действие данного программно-стратегического документа сопряжено с рядом проблем, связанных с приоритетным развитием дальневосточных регионов и недостатком выделяемых средств на развитие забайкальских субъектов РФ [103]. 


\begin{tabular}{|c|c|c|}
\hline 2005 год & 2010 год & 2015 год \\
\hline $\begin{array}{c}\text { ВЫСОКИЙ ПОТЕНЦИАЛ } \\
\text { Хантть-Мапсийский } А O(66,2) \\
\text { Ямало-Ненеикий } A O(61,4)\end{array}$ & $\begin{array}{c}\text { ВЫСОКИЙ ПОТЕНЦИАЛ } \\
\text { Ямало-Ненечкий } А O(62,5) \\
\text { Ханть-Мансийский } A O(54,3)\end{array}$ & $\begin{array}{c}\text { ВЫСОКИй ПОТЕНЦИАЛ } \\
\text { Ямано-Ненечкий } А O(59,2) \\
\text { Ханть-Мансийский } A O(56,9) \\
\rightarrow \text { Сахалинская область }(51,3)\end{array}$ \\
\hline $\begin{array}{c}\text { ВЫСОКИЙ ПОТЕНЦИАЛ } \\
\text { дОМАШНИХ ХОЗЯЙСТВ } \\
\text { Ненеұкий } А O(66,2) \\
\text { Чукотский } А O(63,1) \\
\text { Магадансказ область }(48,2)\end{array}$ & $\begin{array}{c}\text { ВЫСОКИЙ ПОТЕНЦИАЛ } \\
\text { ДОМАШНИХ ХОЗЯЙСТВ } \\
\text { Ненсукий } А O(62,3) \\
\text { Чукотский } А O(51,9) \\
\text { Магаданская область }(49,1)\end{array}$ & $\begin{array}{c}\text { ВЫСОКИЙ ПОТЕНЦИАЛ } \\
\text { ДОМАШНИХ ХОЗЯЙСТВ } \\
\text { ЧУкотский } A O(57,3) \\
\text { Ненеикий } А O(56,8) \\
\text { Магаданская область }(48,9)\end{array}$ \\
\hline 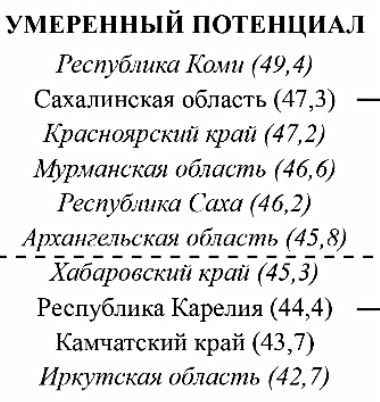 & 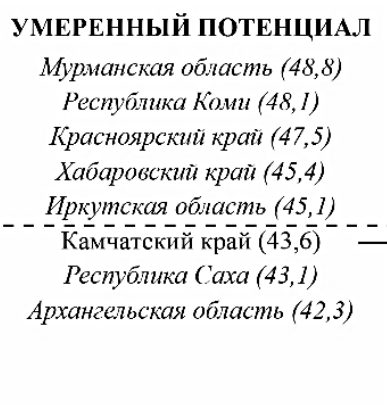 & $\begin{array}{c}\text { УМЕРЕННЫЙ ПОТЕНЦИАЛ } \\
\text { Мурманская область }(46,2) \\
\text { Республика Саха }(45,5) \\
\text { Краснолрский край }(45,3) \\
- \text { Республика Коми }(44,5) \\
\text { Иркутскал область }(44,2) \\
\text { Хабаровский край }(43,2) \\
\text { Архангельская область }(42,1)\end{array}$ \\
\hline $\begin{array}{c}\text { НИЗКИЙ ПОТЕНЦИАЛ } \\
\text { РестУблика Тыва }(26,4)\end{array}$ & $\begin{aligned} & \text { НИзКИй ПОТЕНЦИАЛ } \\
\rightarrow & \text { Республика Карелия }(40,6) \\
\rightarrow & \text { Сахалинская область }(40,6) \\
& \text { Республика Тыва }(33,5)\end{aligned}$ & $\begin{array}{c}\text { НИЗКИй пОТЕНЦИАЛ } \\
\rightarrow \text { Камчатский край }(41,4) \\
\text { Республика Карелия }(36,2) \\
\text { Респубиика Тыъа }(30,1)\end{array}$ \\
\hline СРЕДНЕЕ ЗНАЧЕНИЕ - 49,4 & СРЕДНЕЕ ЗНАЧЕНИЕ - 47,4 & СРЕДНЕЕ ЗНАЧЕНИЕ - 46,8 \\
\hline
\end{tabular}

Рис. 19. Динамика состава групп регионов с различным финансовым потенциалом в 2005-2015 гг. 
Республика Карелия располагается в Северо-Западном федеральном округе в относительной близости от федеральных центров, но это не способствует повышению финансовой самостоятельно региона, напротив, за исследуемый период времени оценка финансового потенциала данной территории снизилась почти на 20 \%, что является худшим показателем среди всех северных субъектов РФ.

Камчатский край располагается на Дальнем Востоке и из 3 регионов отстающей группы имеет наибольшую оценку и достаточно высокие шансы в ближайшее время повысить свой финансовый потенциал, прежде всего, за счет значительных государственных усилий по развитию региона в рамках Стратегии социально-экономического развития Дальнего Востока и Байкальского региона на период до 2025 года. Так, в регионе в качестве целевых ориентиров заявлены высокие темпы роста создания новых рабочих мест (около $20 \%$ прироста за ближайшие пять лет), средние темпы прироста объема ВРП на уровне около $5 \%$, заметное увеличение стоимостного объема производства практически по всем ведущим отраслям.

В настоящий момент существенное увеличение финансового потенциала территорий возможно только при активном государственном участии. Так, для Сахалинской обл., улучшившей свои позиции, характерны реализация крупных инвестиционных проектов с привлечением бюджетного финансирования и формирование системы льгот для бизнеса. На потенциал региона положительное влияние оказало создание условий для развития нефтегазовой отрасли и реализация проектов в области государственно-частного партнерства.

Представляет интерес сравнить результаты, полученные при расчете количественных характеристик финансового потенциала северных регионов, с оценкой показателей социально-экономического положения субъектов РФ, рассчитываемых агентством «РИА Рейтинг» [100] (рис. 20).

При сравнении не учитывались три региона, которые при оценке финансового потенциала были отнесены в отдельную группу «Регионы с высоким финансовым потенциалом домашних хозяйств» (Ненецкий и Чукотский автономные округа, Магаданская обл.) в связи с их специфическими особенностями (высокие относительные показатели доходов населения, формирующие значительный уровень финансового потенциала домохозяйств при относительно низкой численности населения).

Согласно рис. 20, наблюдается в целом положительное значение корреляции между уровнем финансового потенциала региона и его социально-экономическим развитием (коэффициент корреляции между двумя этими рейтингами составляет 0,93, что соответствует сильной (тесной) прямой степени связи).

Регионами, положение которых в сравниваемых рейтингах различается на два места и более, являются:

- Мурманская обл. - характеризуется более мощным финансовым потенциалом по сравнению с уровнем социально-экономического развития, что связано с наличием крупных промышленных предприятий, способных привлекать большой объем финансовых ресурсов для реализации крупных инвестиционных проектов, формировать значительные поступления в региональный бюджет и поддерживать высокий уровень оплаты труда своих работников;

- Иркутская обл. и Красноярский край - отличаются более низким финансовым потенциалом относительно уровня своего социально-экономического развития. Основная причина этого заключается в несоответствии промышленного 
потенциала территорий (Иркутская обл. обеспечивает значительную долю в общероссийском производстве электроэнергии, целлюлозы, вывозе деловой древесины, а Красноярский край является лидером по выработке промышленной продукции на одного жителя) формируемым финансовым ресурсам. Так, в 2015 г. в этих регионах были сформированы региональные бюджеты с дефицитом, а уровень среднедушевых доходов населения были ниже среднероссийского.

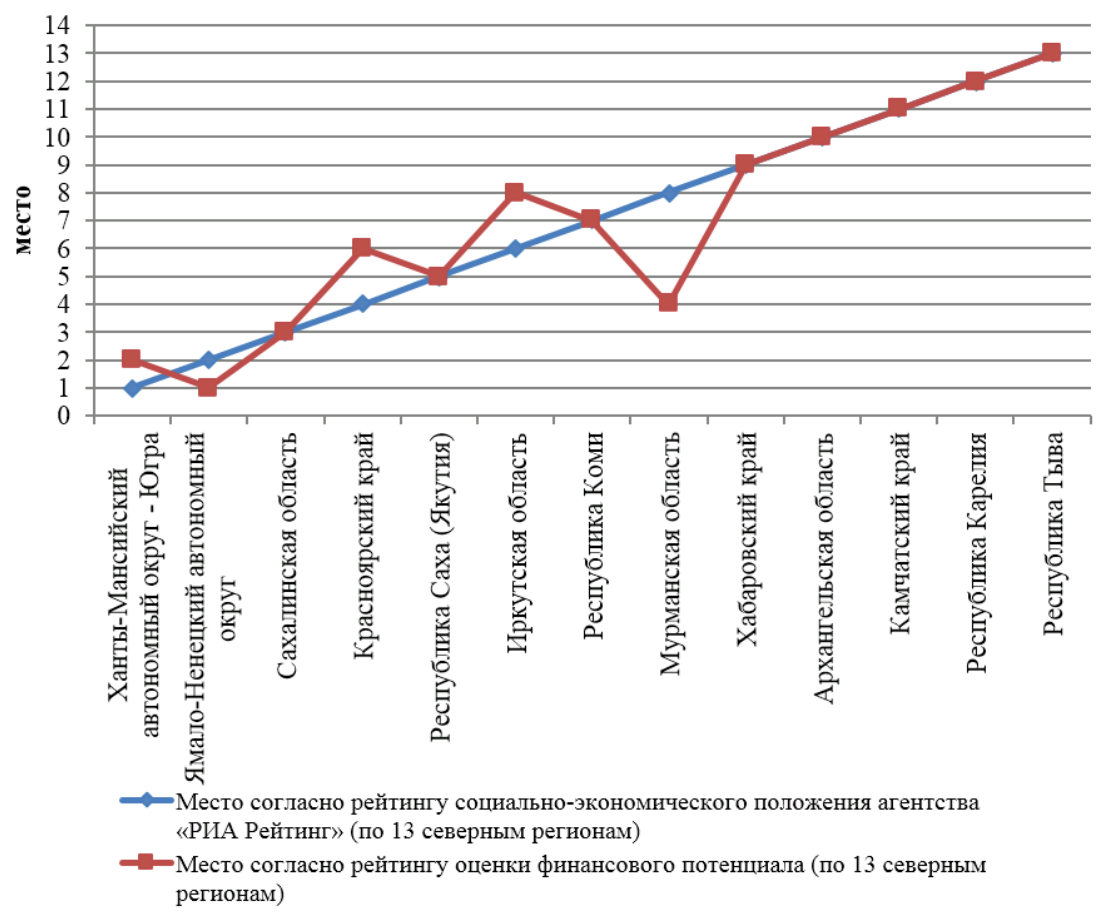

Рис. 20. Сопоставление положения северных регионов по данным агентства «РИА Рейтинг» и на основе оценки финансового потенциала территорий (по данным 2015 г.)

Рассчитанные значения по отдельным составляющим финансового потенциала и его совокупная оценка позволяют определить положение каждого из анализируемых субъектов на координатной плоскости, положительное направление оси абсцисс которой соответствует повышению возможности формировать региональный бюджет за счет собственных доходов (отрицательное направление свидетельствует о необходимости выделения для формирования доходной части бюджета и обеспечения необходимых показателей развития средств с федерального уровня).

Ось ординат предполагает ранжирование регионов по степени возможности вовлечения в инвестиционную сферу финансовых ресурсов внутренних экономических субъектов, в т. ч. хозяйствующих субъектов, домохозяйств и средств финансово-кредитных институтов, присутствующих в регионе (рис. 21).

При определении положения региона относительно оси OX были учтены значения каждого субъекта по такой составляющей финансового потенциала, как налогово-бюджетная (чем выше количественная оценка, тем правее располагается регион на координатной плоскости). 


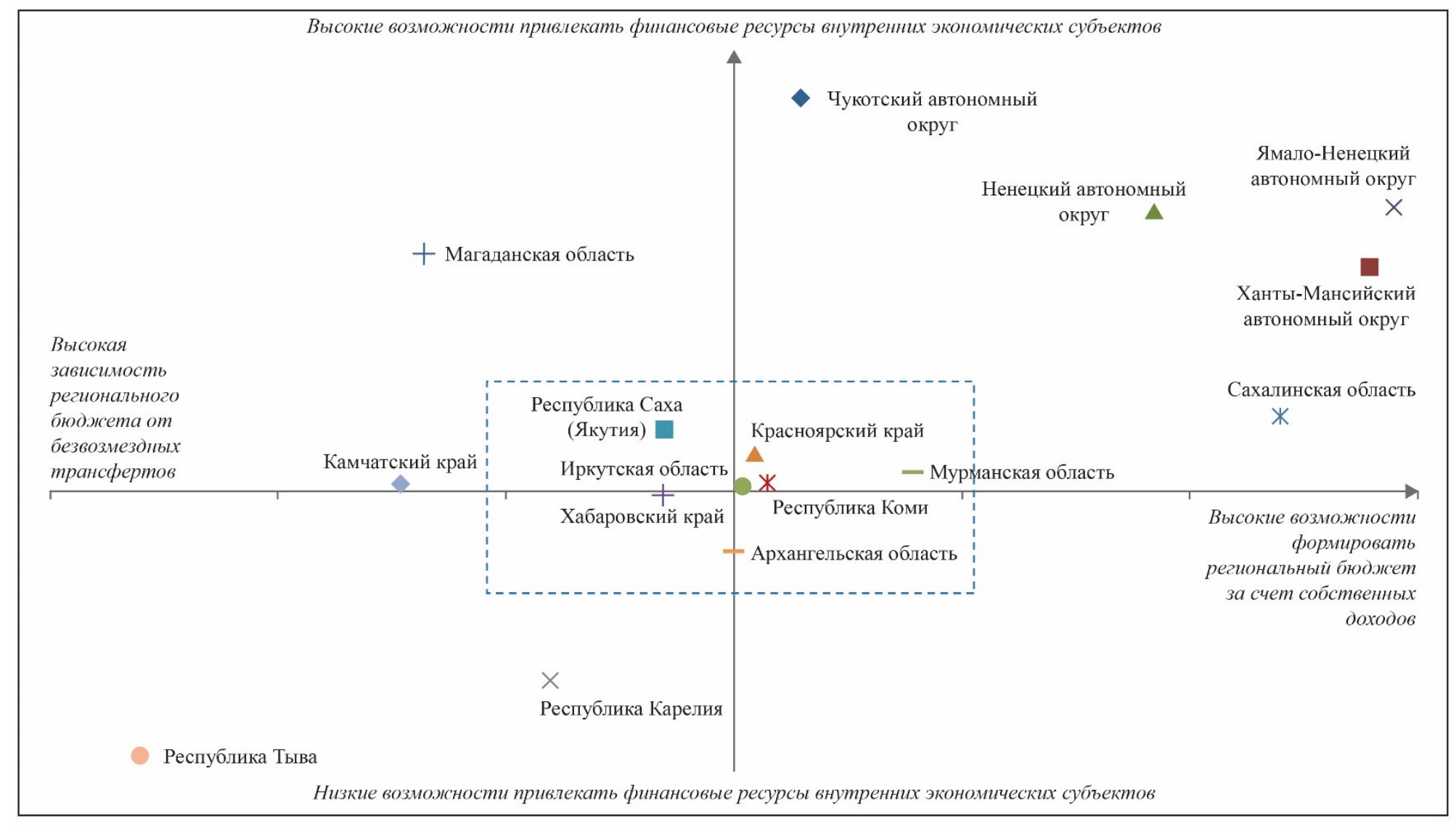

Рис. 21. Возможности северных регионов формировать ресурсы для обеспечения экономического развития (согласно оценке финансового

потенциала в 2015 г.) 
При определении места относительно оси ОУ рассматривалась сумма оценок по трем составляющим финансового потенциала региона (хозяйствующих субъектов, домашних хозяйств и кредитно-финансовый).

Полученное распределение позволяет сформировать общие подходы к финансовому обеспечению экономического развития северных субъектов РФ. Так, для регионов, расположенных в нижнем левом квадранте (республики Тыва и Карелия), в отсутствие достаточных внутренних потенциальных финансовых ресурсов видится наиболее целесообразным применение программно-целевых инструментов развития. Для регионов, вошедших в верхний правый квадрант (Ямало-Ненецкий и Ханты-Мансийский автономные округа, Сахалинская обл.), следует рассмотреть возможность расширения финансовых полномочий и предоставление большей финансовой самостоятельности. Для субъектов, оказавшихся значительно выше горизонтальной оси (Магаданская обл., Красноярский край, Республика Саха), целесообразно рекомендовать активнее привлекать для формирования инвестиционной базы средства экономических субъектов, находящихся в данных регионах, используя разнообразные инструменты (государственно-частное партнерство, реализация региональных заемных систем на основе выпуска облигаций, создание региональных банковских структур, формирование особых экономических зон и др.).

Устойчивое функционирование экономики и социальной сферы северных субъектов РФ, а тем более их развитие, невозможно без государственной поддержки, государственного финансового регулирования. Финансовая политика должна включать методы и инструменты финансового регулирования с учетом факторов, определяющих специфику, место региона в едином народнохозяйственном комплексе и перспективы его развития. Северные территории, по сути дела, являются донорами федерального и региональных бюджетов, и перспективная система организации государственного управления комплексным развитием этих территорий призвана всячески способствовать укреплению этой их позиции. На данные территории должно быть направлено основное внимание федеральной власти.

\section{3. Инструменты формирования финансовых ресурсов для обеспечения устойчивого экономического развития регионов Севера: особенности и специфика применения}

Для повышения эффективности финансового регулирования на уровне регионов и дифференциации выбора рычагов воздействия на пропорции экономического развития территорий представляется обоснованным использование проведенного расчета количественных характеристик общего финансового потенциала северных субъектов РФ и по отдельным его составляющим.

Оценка финансового потенциала служит мерой сравнения возможностей формирования финансовых ресурсов регионов, а также основой для разработки направлений развития региональной финансовой сферы.

Необходимость определения финансового потенциала на уровне каждого региона является исходной ступенью в разработке сводных программ и прогнозов развития. От динамики, величины и качества финансового потенциала в значительной степени зависят уровень развития территории, стабильность политической ситуации, условия жизни населения, а также возможность 
государственного финансового регулирования социально-экономических процессов посредством финансовых ресурсов, находящихся в распоряжении органов власти региона.

Корректная оценка финансового потенциала, а также вовлечение в региональный финансовый механизм не используемого ранее финансового потенциала позволяет достичь более высоких темпов социальноэкономического развития региона и достижения поставленных стратегических целей [104].

Полученные значения отдельных составляющих финансового потенциала и его совокупная оценка позволяют определить возможности (высокие или низкие) северных регионов привлекать финансовые ресурсы, являются основой для разработки рекомендаций по перечню инструментов, которые можно использовать для привлечения финансовых ресурсов в регион, обеспечивающих его устойчивое экономическое развитие. Достаточный уровень обеспеченности финансовыми ресурсами региональных систем является базой для эффективного функционирования кредитной системы, обеспечения реального сектора экономики инвестиционными ресурсами и формирования условий для реализации функций органов власти [105].

В условиях российской специфики спектр инструментов, используемых для привлечения финансовых ресурсов в регион, достаточно ограничен. Кроме того, каждый инструмент имеет свою специфику применения и ограничения в использовании. Основные из них приведены в табл. 20.

Охарактеризуем представленные в таблице инструменты более подробно.

Дотации из Федерального фонда финансовой поддержки субъектов РФ в настоящее время выделяются на основе положений постановления Правительства РФ от 22.11.2004 № 670 «О распределении дотаций на выравнивание бюджетной обеспеченности субъектов Российской Федерации» [106] исходя из показателей бюджетной обеспеченности регионов, которые, в свою очередь, формируются на основе индексов налогового потенциала и бюджетных расходов субъекта РФ.

Субсидии из средств федерального бюджета предоставляются в целях оказания финансовой поддержки при исполнении расходных обязательств, возникающих при выполнении органами власти субъектов РФ полномочий по предметам ведения субъектов РФ и предметам совместного ведения РФ и субъектов РФ, за счет средств федерального бюджета.

Цели и условия предоставления и расходования субсидий, критерии отбора субъектов РФ для выделения субсидий и их распределения между субъектами РФ устанавливаются федеральными законами и (или) принятыми в соответствии с ними нормативными правовыми актами Правительства РФ.

Субвенциии из средств федерального бюджета предоставляются бюджетам субъектов РФ для финансового обеспечения расходных обязательств субъектов и/или муниципальных образований, возникающих при выполнении полномочий РФ, переданных для осуществления органам государственной власти субъектов РФ и/или органам местного самоуправления в установленном порядке. Распределяются между субъектами РФ в соответствии с методиками, утверждаемыми Правительством РФ. Наиболее значимые субвенции: на оплату ЖКУ, социальные выплаты безработным, обеспечение жильем отдельных категорий граждан и т. д. 
Основные инструменты формирования финансовых ресурсов для обеспечения экономического развития региона

\begin{tabular}{|c|c|c|c|}
\hline $\begin{array}{l}\text { № } \\
\text { п/п }\end{array}$ & Инструмент & Категория & $\begin{array}{c}\text { Специфика применения } \\
\text { на основе показателей финансового потенциала }\end{array}$ \\
\hline 1 & $\begin{array}{l}\text { Дотации из Федерального } \\
\text { фонда финансовой } \\
\text { поддержки субъектов РФ }\end{array}$ & \multirow{5}{*}{$\begin{array}{l}\text { Федеральные } \\
\text { финансовые } \\
\text { ресурсы }\end{array}$} & $\begin{array}{l}\text { Целесообразно использовать для регионов, не располагающих } \\
\text { высоким финансовым потенциалом хозяйствующих субъектов, } \\
\text { домохозяйств и кредитно-финансовой сферы }\end{array}$ \\
\hline 2 & $\begin{array}{l}\text { Субсидии из средств } \\
\text { федерального бюджета }\end{array}$ & & $\begin{array}{l}\text { Существенного влияния характеристики финансового потенциала } \\
\text { субъектов РФ на использование данного инструмента не } \\
\text { оказывают }\end{array}$ \\
\hline 3 & $\begin{array}{l}\text { Субвенции из средств } \\
\text { федерального бюджета }\end{array}$ & & e \\
\hline 4 & Бюджетные кредиты & & $\begin{array}{l}\text { Целесообразно использовать для регионов, характеризующихся } \\
\text { низким бюджетно-налоговым потенциалом, не способным } \\
\text { использовать другие источники }\end{array}$ \\
\hline 5 & $\begin{array}{l}\text { Финансирование в рамках } \\
\text { программного метода } \\
\text { развития территорий }\end{array}$ & & $\begin{array}{l}\text { Целесообразно использовать для общности регионов, } \\
\text { характеризуемых сходными показателями финансового } \\
\text { потенциала в целом или его составляющих }\end{array}$ \\
\hline 6 & $\begin{array}{l}\text { Собственные доходы } \\
\text { бюджета }\end{array}$ & $\begin{array}{l}\text { Собственные } \\
\text { средства } \\
\text { региональных } \\
\text { органов власти }\end{array}$ & $\begin{array}{l}\text { Регионам, обладающим высоким финансовым потенциалом } \\
\text { хозяйствующих субъектов и одновременно высоким бюджетно- } \\
\text { налоговым потенциалом целесообразно предоставлять более } \\
\text { широкий объем полномочий в области формирования собственных } \\
\text { бюджетных доходов }\end{array}$ \\
\hline 7 & $\begin{array}{l}\text { Облигационные займы, } \\
\text { коммерческие кредиты } \\
\text { и другие инструменты }\end{array}$ & $\begin{array}{l}\text { Заемные } \\
\text { средства } \\
\text { региональных } \\
\text { органов власти }\end{array}$ & $\begin{array}{l}\text { Могут быть использованы регионами, обладающими высоким } \\
\text { финансовым потенциалом и благоприятными показателями } \\
\text { устойчивости бюджетной системы }\end{array}$ \\
\hline
\end{tabular}


Окончание таблицьь 20

\begin{tabular}{|c|c|c|c|}
\hline $\begin{array}{c}\text { № } \\
\Pi / \Pi\end{array}$ & Инструмент & Категория & $\begin{array}{c}\text { Специфика применения } \\
\text { исходя из показателей финансового потенциала }\end{array}$ \\
\hline 8 & $\begin{array}{l}\text { Государственно-частное } \\
\text { партнерство }\end{array}$ & \multirow{4}{*}{$\begin{array}{l}\text { Частный } \\
\text { капитал }\end{array}$} & $\begin{array}{l}\text { Целесообразно использовать для регионов, располагающих } \\
\text { высоким финансовым потенциалом хозяйствующих субъектов }\end{array}$ \\
\hline 9 & $\begin{array}{l}\text { Банковские кредиты, } \\
\text { средства инвестиционных } \\
\text { институтов (инвестиционных } \\
\text { фондов, страховых компаний, } \\
\text { венчурных фондов и т. д.), } \\
\text { негосударственные } \\
\text { инструменты формирования } \\
\text { госдолга субъектов РФ }\end{array}$ & & $\begin{array}{l}\text { Могут активно использоваться в регионах с высоким потенциалом } \\
\text { финансово-кредитной сферы }\end{array}$ \\
\hline 10 & $\begin{array}{l}\text { Средства внешних } \\
\text { по отношению к региону } \\
\text { инвесторов, в том числе } \\
\text { иностранные инвестиции } \\
\end{array}$ & & $\begin{array}{l}\text { Могут быть использованы в качестве основы финансирования } \\
\text { развития в регионах, характеризуемых одновременно высокими } \\
\text { оценками финансового потенциала хозяйствующих субъектов } \\
\text { и совокупного финансового потенциала }\end{array}$ \\
\hline 11 & $\begin{array}{l}\text { Привлечение средств } \\
\text { населения (сбережений) }\end{array}$ & & $\begin{array}{l}\text { Целесообразно использовать для регионов, располагающих } \\
\text { высоким финансовым потенциалом домохозяйств }\end{array}$ \\
\hline
\end{tabular}


Все три вышеперечисленных инструмента относят к межбюджетным трансфертам, основными отличительными чертами которых является использование для перераспределения финансовых ресурсов между бюджетными уровнями и безвозмездный характер предоставления. В настоящее время в структуре межбюджетных трансфертов наибольшая доля приходится на дотации (по данным 2019 г. - около 40 \%), на субсидии и субвенции приходится соответственно около 27 и $17 \%$ (рассчитано на основании [107]).

Северные и приравненные к ним субъекты РФ характеризуются широким диапазоном значений выделяемых межбюджетных трансфертов. Это иллюстрирует рис. 22, на котором представлены сведения о доле безвозмездных перечислений в структуре совокупных доходов консолидированных бюджетов северных и приравненных к ним субъектов РФ в 2017 г. Данный показатель варьируется от $2 \%$ (Ямало-Ненецкий автономный округ) до 74,0 \% (Республика Тыва). При среднероссийском уровне в $16 \%$ средний уровень доли трансфертов в бюджетных доходах северных и приравненных к ним регионов составляет около $25 \%$, что свидетельствует о высокой зависимости бюджетов рассматриваемой группы субъектов от безвозмездных перечислений.

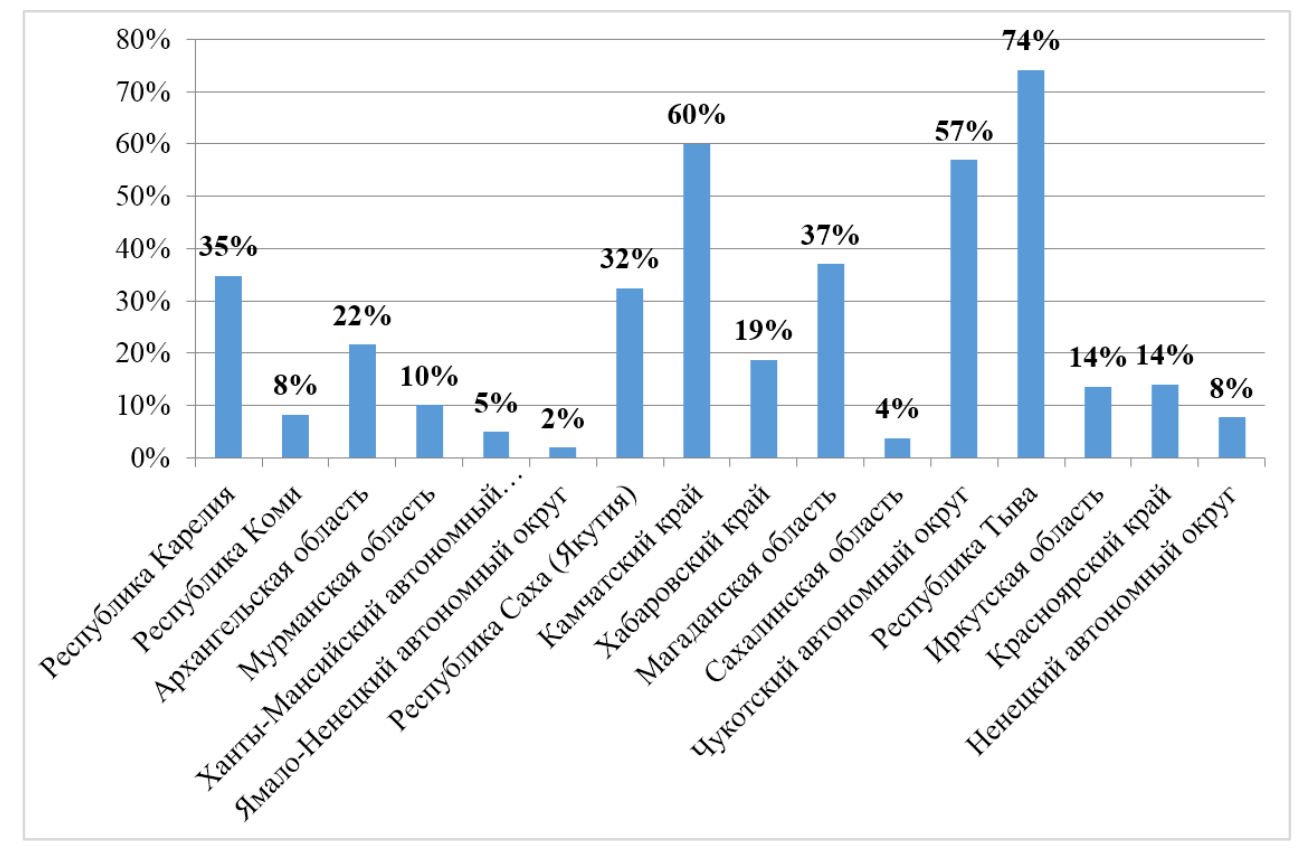

Рис. 22. Доля безвозмездных перечислений в структуре совокупных доходов консолидированных бюджетов северных и приравненных к ним субъектов РФ в 2017 г.

Бюджетные кредиты предусмотрены субъектам РФ для частичного покрытия дефицита бюджетов регионов, покрытия временных кассовых разрывов. Предоставляются в целях погашения долговых обязательств субъекта РФ в виде обязательств по бюджетным кредитам, государственным ценным бумагам субъекта РФ и кредитам, полученным от кредитных организаций, иностранных банков и международных финансовых организаций. Условия предоставления кредитов следующие: 
- обеспечение дефицита регионального бюджета на уровне не более $10 \%$ суммы доходов бюджета субъекта Федерации (без учета безвозмездных поступлений);

- поэтапное сокращение объема коммерческой задолженности к сумме доходов регионального бюджета (без учета безвозмездных поступлений);

- неувеличение и снижение общего объема государственного долга к сумме доходов регионального бюджета (без учета безвозмездных поступлений).

Оценить интенсивность предоставления бюджетных кредитов северным и приравненным к ним субъектам РФ можно н основе показателя доли бюджетных кредитов в налоговых и неналоговых доходах бюджета региона (рис. 23). Среди выделенной группы субъектов диапазон изменения интенсивности использования бюджетных кредитов достаточно высок. Так, на конец 2018 г. ряд субъектов не имел задолженности по бюджетным кредитам вовсе (Ненецкий и Ямало-Ненецкий автономные округа, Сахалинская обл.). Задолженность по бюджетным кредитам других регионов составляла более 50 \% от совокупной доходной базы бюджетов (Республика Карелия, Чукотский автономный округ).

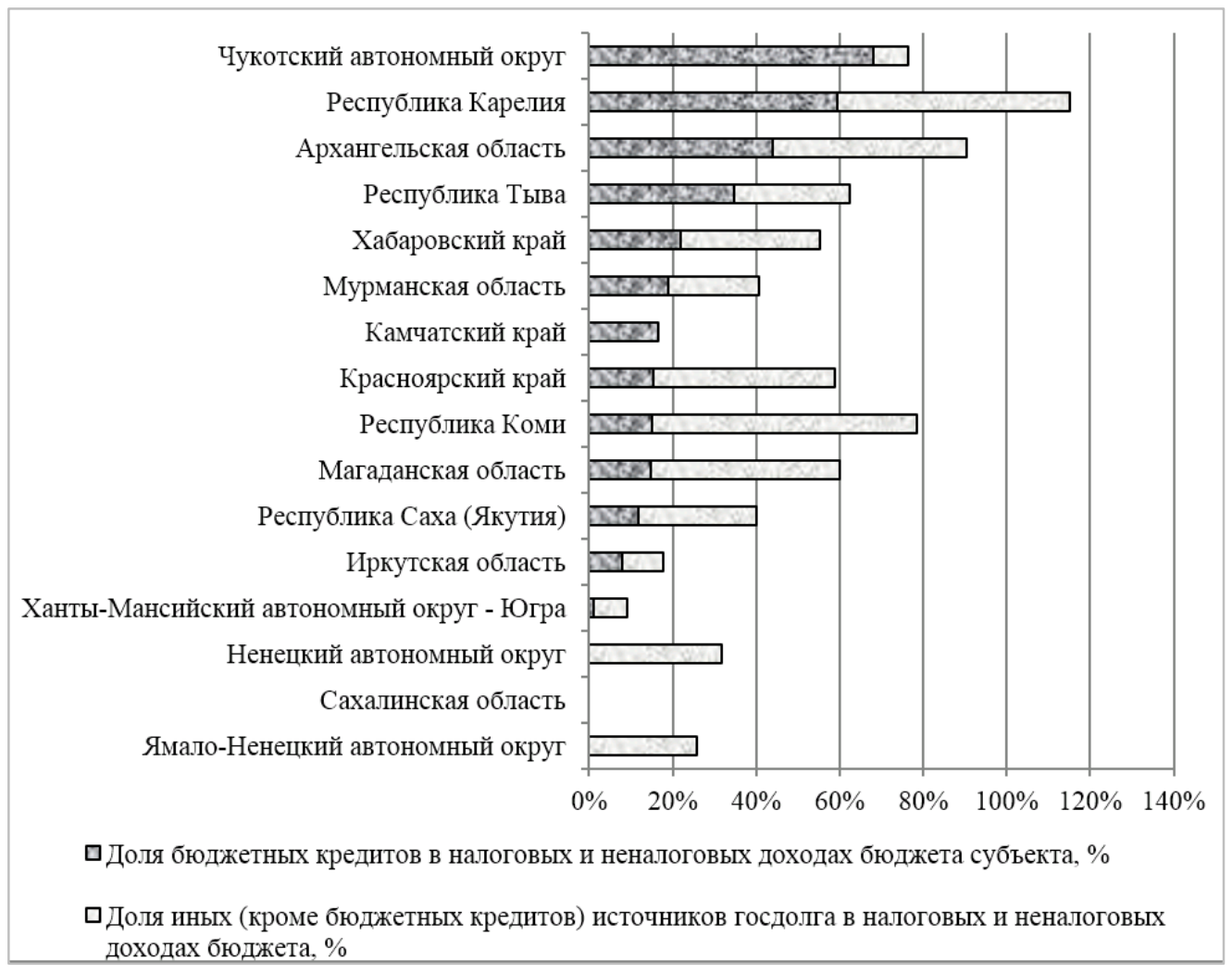

Рис. 23. Уровень использования бюджетных кредитов северными и приравненными к ним субъектами РФ на конец 2018 г. (рассчитано на основании [108])

В последние годы со стороны Минфина РФ наблюдается сокращение объемов выделяемых средств на бюджетное кредитование регионов. Данный инструмент во многом становится антикризисным механизмом для органов 
власти субъектов, используемым чаще всего для рефинансирования имеющейся задолженности (об этом, в частности, говорит структура распределения бюджетных кредитов, смещенная в сторону регионов с низкой оценкой финансового потенциала). Для инвестиционных целей и создания финансовой базы регионального развития Минфин призывает активнее использовать иные источники привлечения дополнительных ресурсов, в частности, облигационные займы. Кроме того, в условиях сохранения определенных кризисных явлений на финансовых рынках регионы придерживаются консервативных принципов формирования госдолга и неактивно привлекают заемные средства.

Финансирование в рамках программного метода развития территорий формируется для реализации структурной, научно-технической и инновационной политики государства, активного воздействия на его социально-экономическое развитие и сосредоточено на реализации крупномасштабных, наиболее важных для государства инвестиционных, научно-технических и инновационных проектов, направленных на решение системных проблем, входящих в сферу компетенции федеральных органов исполнительной власти.

В настоящий момент на развитие отдельных территорий направлено действие следующих программ:

- Развитие Северо-Кавказского федерального округа на период до 2025 года;

- Социально-экономическое развитие Калининградской области;

- Социально-экономическое развитие Республики Крым и г. Севастополя на период до 2020 года;

- Социально-экономическое развитие Дальнего Востока и Байкальского региона;

- Социально-экономическое развитие Арктической зоны Российской Федерации.

Непосредственно на развитие северных и приравненным к ним регионов направлены две последние программы, при этом действие обеих нельзя признать достаточно эффективным. Так, основная проблема программы развития Арктической зоны связана со структурой распределения финансовых ресурсов на ее выполнение (из 190,5 млрд руб. федеральных средств, выделяемых на семь лет реализации программы, более 63 \% приходится на мероприятие «Создание условий функционирования подразделений Вооруженных Сил Российской Федерации в Арктической зоне» [109]) ${ }^{17}$. Недостатком исполнения программы «Социально-экономическое развитие Дальнего Востока и Байкальского региона» [110] является явный перекос усилий государства в сторону Дальнего Востока, тогда как развитие Байкальского региона будет осуществляться в соответствии с программой по остаточному принципу. В частности, полностью отсутствует финансирование по такой подпрограмме, как «Поддержка реализации инвестиционных проектов в Байкальском регионе». В качестве целевого индикатора в Байкальском регионе заявлено создание 2,63 тыс. новых рабочих мест, тогда как общий прирост по данному показателю с учетом Дальнего Востока составит около 100 тыс. единиц.

17 Для сравнения: объем средств, которые выделяются на реализацию программы «Развитие Северо-Кавказского федерального округа», составляет 303,3 млрд руб., а на выполнение программы «Социально-экономическое развитие Дальнего Востока и Байкальского региона» - 422,7 млрд руб. 
Bсе вышеперечисленные инструменты формирования финансовых ресурсов регионов, исходя из категории источников средств, следует отнести к инструментам федерального финансирования.

Собственные доходы региональных бюджетов формируются за счет налоговых и неналоговых поступлений в региональные бюджеты. В российских условиях использование данного инструмента формирования финансовых ресурсов в регионе ограничено низким уровнем самостоятельности регионов при реализации налоговой политики, высокой концентрацией налоговых потоков в федеральном бюджете, унифицированными налоговыми ставками, применяемыми во всех регионах без учета специфики их экономического развития и финансового потенциала. В этой связи возникает необходимость усилить самодостаточность финансирования территориального развития, не допустить дискриминацию экономически развитых и изначально финансово состоятельных территорий, повысить результативность предоставления инвестиционных льгот [111, с. 500].

Северные и приравненные к ним регионы значительно различаются по такому показателю, как объем налоговых и неналоговых доходов консолидированного бюджета субъекта на душу населения, который может служить основным индикатором эффективности формирования собственной доходной базы региона (рис. 24).

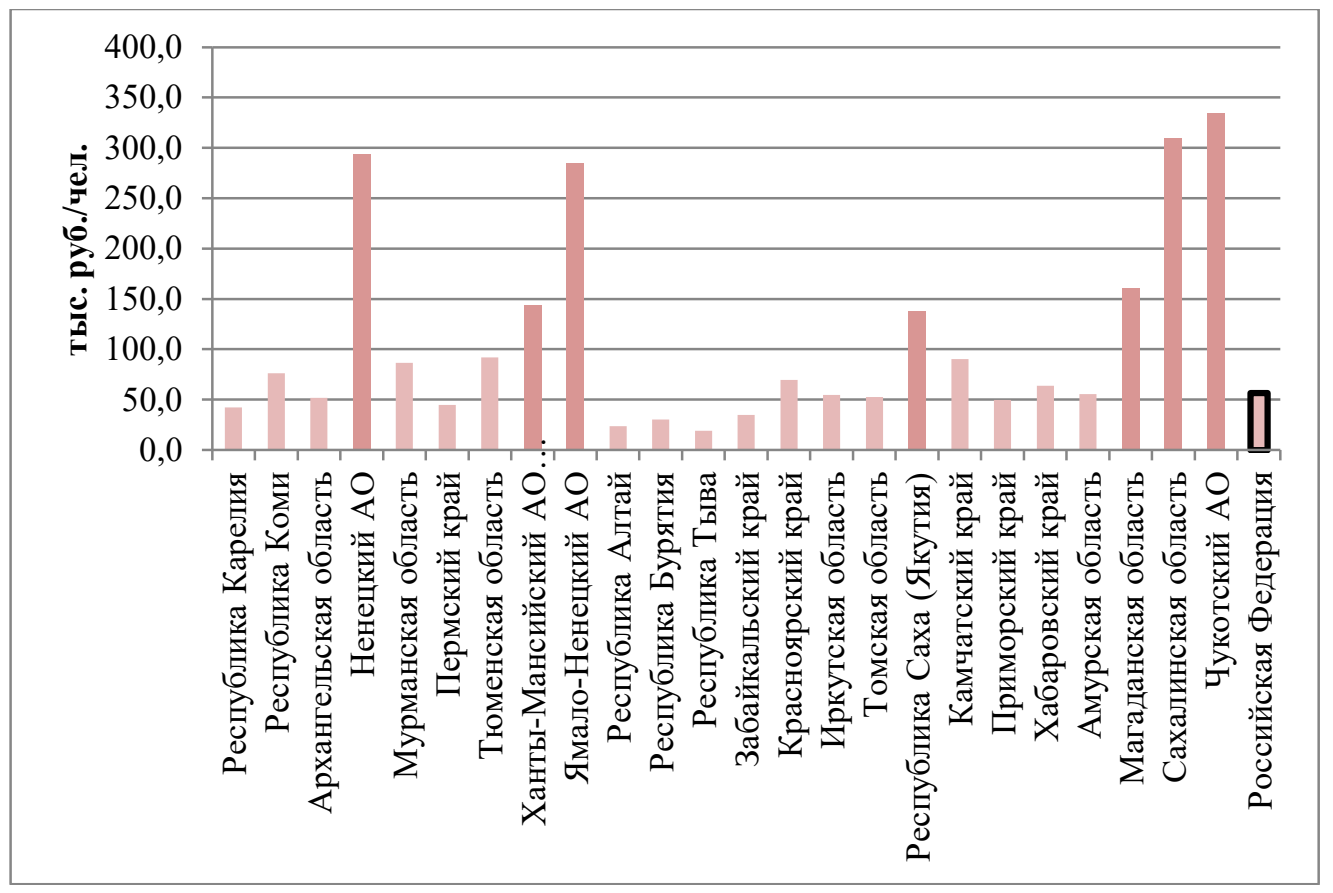

Рис. 24. Объем налоговых и неналоговых доходов консолидированного бюджета на душу населения субъекта РФ (по данным 2017 г.) (рассчитано на основании [112])

Среди анализируемой группы регионов (исключая субъекты с населением менее 200 тыс. чел.) наибольшую собственную доходную бюджетную базу имеют Ямало-Ненецкий и Ханты-Мансийский автономные округа, Республика Саха. 
Помимо федеральных источников финансовых ресурсов и собственных средств региональных органов власти, субъекты Федерации для обеспечения экономического развития с различной степенью интенсивности используют привлечение частных финансовых ресурсов.

В рамках государственно-частного партнерства (ГЧП) региональные органы власти привлекают к финансированию инвестиционных проектов (в том числе имеющих социально значимый характер) и реализации социальноэкономических программ крупные хозяйствующие субъекты. Усилия региональных органов власти направлены на повышение заинтересованности хозяйствующих субъектов в осуществлении долгосрочных вложений в экономику региона [113, с. 57]. В свою очередь, последним предоставляются налоговые льготы, экономические преференции при ведении бизнеса. Согласно рейтингу регионов по уровню развития ГЧП, который составляет Ассоциация «Центр развития ГЧП», в 2016-2017 гг. среди северных регионов в первую двадцатку лидеров входили Хабаровский край (10-11-е место), Красноярский край (15-е) [114]. Данный рейтинг учитывает развитие трех составляющих ГЧП: развитие институциональной среды в сфере ГЧП; нормативно-правовое обеспечение сферы ГЧП; опыт реализации проектов ГЧП. Следует отметить, что по опыту реализации проектов ГЧП среди северных и приравненных к ним регионов наиболее эффективными являются Хабаровский и Красноярский края.

Банковские кредиты, средства инвестиционных институтов (инвестиционных фондов, страховых компаний, венчурных фондов и т. д.) являются основным инструментом формирования привлеченных средств для хозяйствующих субъектов, которые используются для реализации инвестиционных проектов в регионах базирования. В настоящее время среди северных и приравненных к ним регионов наиболее развитой финансовой инфраструктурой характеризуются Иркутская обл., Хабаровский и Красноярский края.

Средства внешних по отношению к региону инвесторов, в том числе иностранные инвестиции, характерны для регионов, отличающихся высокими темпами экономического роста, наличием выраженных отраслей специализации хозяйства, присутствием инновационных площадок и производств, приграничным расположением. Среди северных регионов лидерами по объему накопленных привлеченных иностранных инвестиций являются Красноярский край, Сахалинская обл. [115] (на них приходится более $12 \%$ от общероссийского значения данного показателя $\left.{ }^{18}\right)$.

Привлечение средств населения (сбережений) в регионах с высоким финансовым потенциалом домохозяйств является значительным резервом формирования финансовой базы экономического развития субъектов РФ. При этом в настоящий момент спектр методов привлечения сбережений населения в региональную экономику ограничен несколькими вариантами: привлечение депозитной базы региональными кредитными учреждениями, выпуск региональных и муниципальных ценных бумаг (облигационные займы для населения). Положительный опыт выпуска долговых инструментов

18 Данное значение является существенным, если учитывать, что около половины от совокупного объема накопленных привлеченных иностранных инвестиций приходится на Москву. 
для граждан к настоящему времени есть у нескольких северных регионов. Так, в 2017 г. собственные облигации для населения начал размещать Ямало-Ненецкий автономный округ [116]. Спрос на них в 1,5 раза превысил стоимостной объем эмиссии, что подтверждает высокую перспективность данного инструмента привлечения финансовых ресурсов для нужд региона.

Выделение отличительных особенностей инструментов формирования финансовых ресурсов в регионе и специфики их применения, исходя из показателей финансового потенциала, позволяет дать рекомендации по мобилизации финансовых ресурсов для целей обеспечения устойчивого экономического развития северных субъектов РФ. Схематично данные рекомендации представлены в табл. 21. обобщения:

Представленные рекомендации позволяют сделать следующие

В настоящий момент среди северных имеются такие субъекты РФ, формирование достаточной финансовой базы для экономического развития которых возможно только при значительном участии федеральных органов власти (Республика Карелия, Республика Тыва). По отношению к этим регионам действенными инструментами увеличения и реализации финансового потенциала должны стать бюджетные трансферты (прежде всего, в форме дотаций) и федеральное финансирование в рамках программных инструментов. При этом более эффективным видится принятие и исполнение программ развития по ограниченному числу территорий (не более четырех регионов), характеризующихся схожими параметрами финансового потенциала.

Большая часть северных регионов способна обеспечить экономическое развитие за счет средств субъектов хозяйствования, базирующихся на их территории. Определяющими условиями для реализации имеющегося у них финансового потенциала является повышение финансовой самостоятельности регионов, расширение бюджетно-налоговых полномочий, создание условий, которые позволили бы оставлять финансовые ресурсы, формируемые крупными промышленными субъектами, в регионах базирования и ограничить возможности их выведения в интересах собственников. Кроме того, для субъектов, обладающих высоким финансовым потенциалом домохозяйств (ЯмалоНенецкий автономный Чукотский, Ханты-Мансийский и Ненецкий автономные округа, Сахалинская и Магаданская обл.), рекомендуется активнее привлекать средства населения в экономику за счет механизмов их трансформации в инвестиционные ресурсы, успешно используемые в настоящее время в некоторых регионах.

Важным условием развития финансового потенциала территорий и, как следствие, повышения темпов их экономического роста является формирование благоприятного инвестиционного климата и привлечение внешних по отношению к регионам инвесторов. При этом следует понимать, что для реализации данной задачи необходим симбиоз усилий региональных и федеральных органов власти, а необходимый результат может быть получен для ограниченного числа северных регионов, для которых характерны высокий уровень развития экономики, достаточный объем имеющегося финансового потенциала, наличие выраженных отраслей специализации хозяйства, присутствие инновационных площадок и производств, приграничное расположение. К таковым на сегодняшний день следует отнести Ханты-Мансийский автономный округ, Сахалинскую и Магаданскую обл. 
Рекомендации по повышению финансового обеспечения экономического развития северных регионов с учетом сформированного финансового потенциала территорий

\begin{tabular}{|c|c|c|c|}
\hline $\begin{array}{l}\text { № } \\
\Pi / \Pi\end{array}$ & $\begin{array}{c}\text { Инструмент формирования } \\
\text { финансовых ресурсов региона }\end{array}$ & Особенности использования & Для регионов \\
\hline 1 & $\begin{array}{l}\text { Дотации из Федерального фонда } \\
\text { финансовой поддержки } \\
\text { субъектов РФ }\end{array}$ & $\begin{array}{l}\text { Повышение выделяемых объемов дотаций } \\
\text { бюджетам регионов с наиболее низким } \\
\text { уровнем финансового потенциала за счет } \\
\text { изменения методики распределения } \\
\text { дотаций }\end{array}$ & $\begin{array}{l}\text { Республика Карелия } \\
\text { Республика Тыва }\end{array}$ \\
\hline 2 & Бюджетные кредиты & $\begin{array}{l}\text { Повышение лимита предоставления } \\
\text { бюджетных кредитов регионам, имеющим } \\
\text { высокие оценки бюджетно-налоговой } \\
\text { составляющей финансового потенциала }\end{array}$ & $\begin{array}{l}\text { Ямало-Ненецкий автономный округ } \\
\text { Ханты-Мансийский автономный округ } \\
\text { Ненецкий автономный округ } \\
\text { Сахалинская обл. }\end{array}$ \\
\hline 3 & $\begin{array}{l}\text { Финансирование в рамках } \\
\text { программного метода развития } \\
\text { территорий }\end{array}$ & $\begin{array}{l}\text { Пересмотр федеральных целевых программ } \\
\text { с отказом от реализации программ развития } \\
\text { макротерриторий («Экономическое } \\
\text { и социальное развитие Дальнего Востока } \\
\text { и Байкальского региона на период } \\
\text { до } 2025 \text { года») и принятием программ, } \\
\text { направленных на развитие ограниченного } \\
\text { числа регионов со схожими } \\
\text { характеристиками финансового потенциала }\end{array}$ & $\begin{array}{l}\text { Республика Тыва (в сочетании с регионами, } \\
\text { приравненными к северным: Республика } \\
\text { Бурятия - Забайкальский край - } \\
\text { Республика Алтай). } \\
\text { Приморский край — Хабаровский край — } \\
\text { Камчатский край (в сочетании с регионом, } \\
\text { приравненным к северным: Амурская обл.). } \\
\text { Республика Коми — Архангельская обл. - } \\
\text { Республика Карелия }\end{array}$ \\
\hline 4 & Собственные доходы бюджета & $\begin{array}{l}\text { Расширение бюджетных и налоговых } \\
\text { полномочий и повышение финансовой } \\
\text { самостоятельности регионов, } \\
\text { характеризующихся высоким финансовым } \\
\text { потенциалом }\end{array}$ & $\begin{array}{l}\text { Ханты-Мансийский автономный округ } \\
\text { Сахалинская обл. } \\
\text { Мурманская обл. } \\
\text { Республика Саха (Якутия) } \\
\text { Иркутская обл. }\end{array}$ \\
\hline
\end{tabular}


Окончание таблицы 21

\begin{tabular}{|c|c|c|c|}
\hline $\begin{array}{l}\text { № } \\
\Pi / \Pi\end{array}$ & $\begin{array}{c}\text { Инструмент формирования } \\
\text { финансовых ресурсов региона }\end{array}$ & Особенности использования & Для регионов \\
\hline 5 & $\begin{array}{l}\text { Государственно-частное } \\
\text { партнерство }\end{array}$ & $\begin{array}{l}\text { Создание условий для более активной } \\
\text { реализации государственно-частного } \\
\text { партнерства (ГЧП) в регионах, имеющих } \\
\text { промышленный характер экономики } \\
\text { и присутствие крупных устойчивых } \\
\text { предприятий за счет предоставления льгот } \\
\text { для субъектов реализующих ГЧП-проекты } \\
\text { в регионах базирования }\end{array}$ & $\begin{array}{l}\text { Чукотский автономный округ } \\
\text { Ханты-Мансийский автономный округ } \\
\text { Республика Саха (Якутия) } \\
\text { Красноярский край } \\
\text { Иркутская обл. }\end{array}$ \\
\hline 6 & $\begin{array}{l}\text { Банковские кредиты, средства } \\
\text { инвестиционных институтов } \\
\text { (инвестиционных фондов, } \\
\text { страховых компаний, венчурных } \\
\text { фондов и т. д.) }\end{array}$ & $\begin{array}{l}\text { Усиление регионального участия } \\
\text { в создании инвестиционных институтов, } \\
\text { в том числе за счет создания региональных } \\
\text { банков и региональных венчурных } \\
\text { и инвестиционных фондов }\end{array}$ & $\begin{array}{l}\text { Ямало-Ненецкий автономный округ } \\
\text { Магаданская обл. } \\
\text { Хабаровский край }\end{array}$ \\
\hline 7 & $\begin{array}{l}\text { Средства внешних по отношению } \\
\text { к региону инвесторов, в том числе } \\
\text { иностранные инвестиции }\end{array}$ & $\begin{array}{l}\text { Создания условий привлечения внешних } \\
\text { по отношению к региону инвесторов, в том } \\
\text { числе за счет формирования особых } \\
\text { экономических зон (ОЭЗ) и формирования } \\
\text { банков данных потенциальных } \\
\text { инвестиционных проектов и площадок }\end{array}$ & $\begin{array}{l}\text { Ханты-Мансийский автономный округ } \\
\text { Сахалинская обл. } \\
\text { Магаданская обл. }\end{array}$ \\
\hline 8 & $\begin{array}{l}\text { Привлечение средств населения } \\
\text { (сбережений) }\end{array}$ & $\begin{array}{l}\text { Организация выпуска облигационных } \\
\text { региональных займов для населения } \\
\text { с использованием привлеченных } \\
\text { финансовых ресурсов на инвестиционные } \\
\text { цели }\end{array}$ & $\begin{array}{l}\text { Ямало-Ненецкий автономный округ } \\
\text { Чукотский автономный округ } \\
\text { Ханты-Мансийский автономный округ } \\
\text { Ненецкий автономный округ } \\
\text { Сахалинская обл. } \\
\text { Магаданская обл. }\end{array}$ \\
\hline
\end{tabular}


В целом, оценка финансового потенциала территории должна являться основой управления и перераспределения финансовых потоков между всеми участниками экономической системы региона. Выявление наиболее перспективных элементов хозяйства региона с точки зрения возможности генерирования финансовых ресурсов, которые можно привлечь для обеспечения экономического роста субъекта РФ, должно способствовать созданию в регионе обоснованной системы финансовых инструментов развития и повышению эффективности использования рычагов финансирования инвестиционной деятельности.

В конечном итоге анализ количественных и качественных характеристик финансового потенциала отдельных субъектов РФ должен позволить сформировать дифференцированный подход к реализации региональной финансовой политики и разработке индивидуальных подходов к финансовому регулированию с учетом специфики финансовых систем территорий и их способности формировать необходимые финансовые ресурсы в различных секторах экономики. 


\section{ЗАКЛЮЧЕНИЕ}

Выполненные исследования позволяют сделать следующие выводы.

Финансовые ресурсы являются одним из главных факторов обеспечения высоких темпов экономического роста региона, сложной категорией, организация и управление которой требуют учета специфики как непосредственно параметров, характеризующих динамику и структуру финансовых ресурсов, так и сфер региональной системы, где они формируются и используются. Формирование и использование финансовых ресурсов тесным образом связано с процессами образования и перераспределения доходов всех участников финансовых отношений в регионе (населения, предпринимательских структур, органов власти и др.).

Финансовое регулирование происходит, с одной стороны, через стимулирование одних сегментов экономической системы путем концентрации в них финансовых ресурсов, с другой - через сдерживание иных сегментов на основе ограничения объема поступающих в них финансовых ресурсов. Для этого используются различные формы и методы, которые представляют инструментарий финансового регулирования.

Возможность использования монетарных и фискальных рычагов для регулирования финансовых процессов имеет существенные отличия на разных уровнях управления. Для региональных органов власти использование монетарных рычагов является ограниченным, в то время как фискальные рычаги являются действенным инструментом регулирования и перераспределения финансовых потоков в субъектах РФ.

Актуальность оценки финансового потенциала территорий определяется тем, что от его динамики, объема и качества зависит уровень развития территории, стабильность политической ситуации, условия жизни населения, а также возможность государственного финансового регулирования социальноэкономических процессов посредством финансовых ресурсов, находящихся в распоряжении органов власти региона.

Изучение и анализ наиболее часто упоминаемых в современной литературе методик оценки финансового потенциала позволили обобщить приведенные подходы и сформулировать ряд утверждений относительно содержания расчетного механизма финансового потенциала.

Для оценки совокупного финансового потенциала необходимо по каждому структурному элементу (бюджетно-налоговый потенциал, потенциал хозяйствующих субъектов, потенциал домохозяйств, потенциал финансовокредитной сферы) определять объем и уровень финансового потенциала.

Управление финансовым потенциалом должно осуществляться непрерывно на всех уровнях с учетом особенностей как данного региона, так и текущего момента, а также воздействия внешних нерегулируемых на уровне региона факторов.

Отличительной особенностью финансового регулирования развития арктических территорий за рубежом является применение методов, в большей степени соответствующих не регулированию, а координации, предполагающей взаимовыгодное партнерство с субъектами хозяйствования на них.

Зарубежные территории Крайнего Севера и Арктики характеризуются более низкими показателями социально-экономического развития, формирования 
ВРП, обеспеченности населения услугами. В одних странах такие различия проявляются в большей степени (Канада, Финляндия, США, Дания), в других в меньшей (Норвегия, Швеция).

В качестве финансовых инструментов развития северных территорий используются как прямые рычаги - программно-целевые инструменты и системы финансового выравнивания на основе межбюджетных трансфертов (Финляндия, Канада, Швеция, Норвегия), так и косвенные - формирование привлекательных условий для субъектов хозяйствования на основе льготных систем налогообложения, субсидирования процентных ставок, формирования выплат населению из специализированных фондов (США, Дания).

Региональный финансовый потенциал является индикатором, определяющим реакцию экономики субъекта Федерации на принимаемые управленческие решения, позволяет сопоставить финансовые возможности различных регионов и оценить конкурентоспособность конкретного региона.

Северные субъект существенно различаются по уровню регионального финансового потенциала в целом и отдельных составляющих его элементов в частности.

По коэффициенту покрытия расходов (отношение собственных бюджетных доходов к совокупным расходам) 11 регионов из 16 имеют показатели ниже среднероссийских. У 5 регионов этот коэффициент превышает среднероссийский уровень. По коэффициенту концентрации собственных доходов 9 регионов имеют значения выше среднероссийских, остальные 7 ниже. По коэффициенту обеспеченности населения налоговыми платежами резко выделяется тройка - Ненецкий, Ханты-Мансийский и Ямало-Ненецкий автономные округа, имеющие показатели, превышающие среднероссийские в 1315 раз, в Республике Тыва и Камчатском крае самые низкие значения.

Все регионы Крайнего Севера, кроме Республики Карелия, имеют значения коэффициента, характеризующего отношение сбережений населения к общим доходам, выше среднероссийского показателя. Значения коэффициента, показывающего отношение среднедушевого дохода к прожиточному уровню в регионе, только у 4 регионов выше среднероссийского значения (Ненецкий, Ямало-Ненецкий, Чукотский автономные округа и Сахалинская обл.), почти на уровне среднероссийского - у Ханты-Мансийского автономного округа, у остальных - ниже среднероссийского показателя. Практически во всех регионах показатель численности населения с денежными доходами выше прожиточного минимума на уровне или выше среднероссийского значения, в единственном регионе - Республике Тыва - он ниже среднероссийского.

Характеризующие финансовый потенциал хозяйствующих субъектов коэффициенты в целом показывают явное преимущество Ханты-Мансийского АО перед остальными регионами; самые низкие значения отмечаются у Республики Тыва.

По коэффициентам, характеризующим потенциал финансово-кредитной сферы, можно выделить Ямало-Ненецкий АО, остальные субъекты Федерации имеют показатели на уровне среднероссийских (таких немного) или ниже среднероссийских значений.

Количественная оценка финансового потенциала включая его составляющие, северных регионов, выполненная по авторской методике, позволила провести группировку регионов. 
В группу регионов с низким уровнем финансового потенциала вошли Камчатский край, республики Карелия и Тыва.

В группе северных регионов со средним уровнем финансового потенциала выделено две подгруппы. К первой подгруппе (уровень финансового потенциала, близкий к низкому) отнесены Архангельская обл., Республика Коми, Иркутская обл., Хабаровский край. Во вторую подгруппу (уровень финансового потенциала, близкий к среднероссийскому) вошли Мурманская обл., Красноярский край, Республика Саха (Якутия).

В группе с высоким уровнем финансового потенциала находятся Сахалинская обл., Ямало-Ненецкий и Ханты-Мансийский автономные округа.

В отдельную группу объединены регионы, имеющие высокий или близкий к высокому уровень финансового потенциала за счет значительного финансового потенциала домашних хозяйств. Это Чукотский и Ненецкий автономные округа и Магаданская обл.

За анализируемое десятилетие $(2005,2010,2015$ гг.) в 12 регионах из 16 наблюдается снижение количественных показателей финансового потенциала относительно среднероссийских значений. Динамика оценки отдельных составляющих финансового потенциала свидетельствует о снижении в последнее десятилетие средних параметров бюджетно-налогового, кредитнофинансового потенциалов и потенциала домашних хозяйств при росте значений потенциала хозяйствующих субъектов.

Рассчитанные значения финансового потенциала по отдельным составляющим и его совокупная оценка позволяют определить положение каждого региона, его возможности формировать финансовые ресурсы и служат основой для разработки рекомендаций по перечню инструментов, которые возможно использовать для привлечения финансовых ресурсов в регион.

Проведенное исследование дает основание утверждать, что выполненная оценка финансового потенциала региона позволяет рассматривать его в воспроизводственном аспекте и выявлять наличие финансовых возможностей, достаточных для устойчивого, сбалансированного и интенсивного развития региона на текущий период и в долгосрочной перспективе. Финансовое регулирование должно быть направлено на формирование необходимых условий для увеличения финансового потенциала государства в целом и регионов в частности. 


\section{БИБЛИОГРАФИЧЕСКИЙ СПИСОК}

1. Савдерова, A. Ф. Приоритетность финансового потенциала региона в обеспечении его устойчивого экономического развития / А. Ф. Савдерова // Образование и наука в современных условиях. 2014. № 1 (1). С. 292-295.

2. Мирошникова, Т. К. Финансовый потенциал региона: сущность, понятие, критерии оценки / Т. К. Мирошникова // Азимут научных исследований: экономика и управление. 2017. Т. 6, № 1 (18). С. 126-129.

3. Федоткина, О. П. Финансово-инвестиционный потенциал региона в контексте устойчивого развития / О. П. Федоткина // Региональная экономика и управление: электрон. науч. журн.. 2014. № 3. С. 1-10.

4. Стрельникова, С. В. Привлечение денежных средств населения в деловой оборот региона : специальность 08.00 .05 «Экономика и управление народным хозяйством» : автореферат диссертации на соискание ученой степени кандидата экономических наук / Стрельникова Светлана Владимировна. Ижевск, 2006. 25 с.

5. Пащенко, М. П. Совершенствование мониторинга экономического развития регионов Южного федерального округа : специальность 08.00.05 «Экономика и управление народным хозяйством» : диссертация на соискание ученой степени кандидата экономических наук / Пащенко Михаил Петрович. Ставрополь, 2008. 189 с.

6. Фетисов, Г. Г. Региональная экономика и управление : учебник / Г. Г. Фетисов, Орешин В. П. Москва : ИНФРА-М, 2006. 416 с. (Высшее образование).

7. Вербиненко, E. A. Инструменты, формы и методы финансового регулирования развития арктических территорий: зарубежный опыт / Е. А. Вербиненко, Р. В. Бадылевич, В. С. Острецов // Север и рынок: формирование экономического порядка. 2017. № 2. С. 104-115.

8. Куцури, Г. Н. Текущее и стратегическое регулирование финансовой системы региона / Г. Н. Куцури // Вестник Северо-Осетинского государственного университета имени Коста Левановича Хетагурова. 2013. № 4. С. 424-428.

9. Галлямов, Ф. Ф. Финансовая система региона. Комплексное регулирование / Ф. Ф. Галлямов // Экономика и управление: проблемы, решения. 2012. № 2. C. 34-40.

10. Пономаренко, Г. Н. Финансовые инструменты регулирования экономического развития региона / Г. Н Пономаренко // Региональные проблемы преобразования экономики. 2012. № 1. С. 100-106.

11. Дьякова, Е. Б. Развитие механизма бюджетного регулирования региональных социально-экономических процессов / Е. Б. Дьякова // РИСК: Ресурсы, информация, снабжение, конкуренция. 2010. № 3.2. С. 110-112.

12. Малахов, В. П. Экономический рост региональной экономики на основе совершенствования инвестиционного климата и бюджетной политики / В. П. Малахов // Вестник ТИСБИ. 2012. № 3. С. 33-38.

13. Велибекова, Л. A. Финансово-налоговая политика как инструмент регулирования экономики региона / Л. А. Велибекова, М. Г. Юсупова // Экономика и управление: анализ тенденций и перспектив развития. 2015. № 23. С. $125-128$.

14. Финансы : учебник для вузов / под редакцией Г. Б. Поляка. 2-е изд., перераб. и доп. Москва : ЮНИТИ-ДАНА, 2003. 607 с. 
15. Бабич, А. М. Государственные и муниципальные финансы : учебник для вузов / А. М. Бабич, Л. Н. Павлова. Москва : Финансы : ЮНИТИ, 1999. 687 с.

16. Вербиненко, E. A. Финансовые рычаги как инструмент регулирования развития северных регионов / Е. А. Вербиненко, Р. В. Бадылевич // Север и Арктика в новой парадигме мирового развития. Лузинские чтения - 2016. 2016. С. 568-574.

17. Государственный долг. Объем и структура государственного долга субъектов РФ и долга муниципальных образований. 2018 год (ежемесячные данные с 01.02.2018 по 01.01.2019). Текст : электронный // Минфин России : офиц. сайт. URL: https://www.minfin.ru/ru/perfomance/public_debt/subdbt/ 2018/ (дата обращения: 15.06.2019).

18. Основные направления единой государственной денежно-кредитной политики на 2019 год и период 2020 и 2021 годов : [одобрено Советом директоров Банка России 26.10.2018]. Текст : электронный // Центральный банк РФ : офиц. сайт. URL: http://www.cbr.ru/content/document/ file/48125/on_2019 (2020-2021).pdf (дата обращения: 18.06.2019).

19. О Центральном банке Российской Федерации (Банке России) : федер. закон от 10.07.2002 № 86-Ф3. Текст : электронный // Президент России : офиц. сайт. URL: http://www.kremlin.ru/acts/bank/18296 (дата обращения: 10.11.2018).

20. О территориальных учреждениях Банка России : положение ЦБ РФ от 11.04.2016 № 538-П // Вестник Банка России. 2016. 15 апреля. № 39.

21. Аванесова, P. Р. Региональный аспект денежно-кредитной политики, особенности ее реализации / Р. Р. Аванесова // Современные научные исследования: исторический опыт и инновации : сборник материалов междунар. науч.-практ. конф. 2017. С. 54-61.

22. Сперанская, Л. Л. Анализ воздействия денежно-кредитных инструментов Центробанка на инвестиционные процессы региона / Л. Л. Сперанская // Вестник Пермского университета. Серия: Экономика. 2012. № 1 (12). С. 12-17.

23. Волков, М. Ю. Денежно-кредитная политика и ее реализация на региональном уровне : 08.00.10 «Финансы, денежное обращение и кредит» : диссертация на соискание ученой степени кандидата экономических наук / Волков Михаил Юрьевич. Саратов, 2005. 161 с.

24. Бадылевич, Р. В. Специфика и основные тенденции развития банковских систем регионов Арктической зоны РФ / Р. В. Бадылевич // Север и рынок: формирование экономического порядка. 2016. № 4 (51). С. 189-199.

25. Keynes, J. M. The General Theory of Employment, Interest And Money / J. M. Keynes ; The Royal Economic Society. Third Edition Published. 2007. 428 p.

26. Friedman, M. Studies in the Quantity Theory of Money / M. Friedman. Chicago : University of Chicago Press, 1956. 274 p.

27. Meltzer, A. H. Monetary Theory and Monetary History / A. H. Meltzer // Schweizerische Zeitschfrit für Volkswirtschaft und Statistik. 1965. No. 101 (4). P. 404-22.

28. О ключевой ставке Банка России и других мерах Банка России : пресс-релиз от 16 декабря 2014 г. Текст : электронный // Центральный банк РФ : офиц. сайт. URL: https://cbr.ru/press/pr/?file=16122014_004533dkp2014-1216T00_39_23.htm (дата обращения: 10.11.2018).

29. Fisher, I. The Purchasing Power of Money / I. Fisher. New York : Macmillan, $1911.515 \mathrm{p}$. 
30. Бердышев, A. B. Сущность обязательных резервов и практика их использования в России / А. В. Бердышев // Аудит и финансовый анализ. 2008. № 1. C. 13-18.

31. Сухарев, А. Н. Норма обязательных резервов для коммерческих банков: теория и практика / А. Н. Сухарев // Финансы и кредит. 2017. Т. 23, № 41 (761). C. 2456-2467.

32. Сперанская, Л. Л. Совершенствование денежно-кредитной политики России с учетом различий в реакциях региональных экономик : специальность 08.00.10 «Финансы, денежное обращение и кредит» : диссертация на соискание ученой степени кандидата экономических наук / Сперанская Луиза Леонидовна. Москва : Рос. акад. нар. хоз-ва и гос. службы при Президенте РФ, 2015. $154 \mathrm{c}$.

33. Резепин, $A$. В. Исследование регионального механизма денежно-кредитной трансмиссии (на примере Челябинской области) / А. В. Резепин // Актуальные вопросы экономических наук. 2009. № 9-2. С. 78-83.

34. Юдинцева, Л. А. Влияние денежно-кредитной политики на экономику: региональный аспект / Л. А. Юдинцева // Финансы и бизнес. 2017. № 2. C. $42-53$

35. Вербиненко, E. A. Значение оценки финансового потенциала региона для финансового регулирования развития северных территорий / Е. А. Вербиненко, Р. В. Бадылевич // Управление экономическими системами : электрон. науч. журн. 2017. № 12 (106). С. 36.

36. Бюджетный кодекс Российской Федерации : федер закон от 31.07 .1998 № 145-Ф3 // Российская газета. 1998. 12 августа, № 153-154.

37. О Порядке осуществления мониторинга и оценки качества управления региональными финансами : приказ Минфина России от 03.12.2010 № 552 Текст : электронный // Справочная правовая система «КонсультантПлюс» : [сайт]. URL: http://www.consultant.ru/document/cons_doc_LAW_126489/ (дата обращения: 27.03.2019).

38. Вербиненко, E. A. Методологические и практические аспекты оценки межбюджетных отношений на региональном уровне (на примере Мурманской области) / Е. А. Вербиненко, Р. В. Бадылевич // Север и рынок: формирование экономического порядка. 2015. № 4. С. 44-54.

39. Барулин, С. В. Налоговый менеджмент // С. В. Барулин, Е. А. Ермакова, В. В. Степаненко Москва : Омега-Л, 2007. 272 с.

40. Об основах налоговой системы в Российской Федерации : закон РФ от 27.12.1991. № 2118-1. Текст : электронный // Справочная правовая система «Консультант Плюс» : [сайт]. URL: http://www.consultant.ru/ document/cons_doc_LAW_207/(дата обращения: 10.11.2018).

41. Налоговый кодекс Российской Федерации : федер. закон от 31.07.1998 № 146Ф3 (ред. от 01.10.2015) // Российская газета. 1998. 6 августа, № 148-149.

42. Гаджиева, В. T. Государственные заказы как инструмент государственного финансового регулирования / В. Т. Гаджиева // Бизнес. Образование. Право. Вестник Волгоградского института бизнеса. 2011. № 1. С. 176-183.

43. О контрактной системе в сфере закупок товаров, работ, услуг для обеспечения государственных и муниципальных нужд : федер. закон от 05.04.2013 № 44Ф3. Текст : электронный // Справочная правовая система «Консультант 
Плюс» : [сайт]. URL: http://www.consultant.ru/document/cons_doc_LAW_144624/ (дата обращения: 10.11.2018).

44. О закупках товаров, работ, услуг отдельными видами юридических лиц : федер. закон от 18.07.2011 № 223-Ф3. Текст : электронный // Справочная правовая система «Консультант Плюс» : [сайт]. URL: http://www.consultant.ru/ document/cons_doc_LAW_116964/(дата обращения: 10.11.2018).

45. Система закупок в России» за 2018 год : экспертный доклад / НИУ «Высшая школа экономики. 2019. URL: https://fcs.hse.ru/data/2019/04/01/1190217413/ doklad-2018.pdf (дата обращения 10.07.2019).

46. Савдерова, A. Ф. Приоритетность финансового потенциала региона в обеспечении его устойчивого экономического развития / А. Ф. Савдерова // Образование и наука в современных условиях. 2014. № 1 (1). С. 292-295.

47. Мирошникова, Т. К. Финансовый потенциал региона: сущность, понятие, критерии оценки / Т. К. Мирошникова // Азимут научных исследований: экономика и управление. 2017. Т. 6, № 1 (18). С. 126-129.

48. Колчина, О. А. Методика оценки инвестиционного климата муниципального образования / О. А. Колчина // Известия ЮФУ. Технические науки. 2006. № 10 (65). C. 134-137.

49. Сонина, Т. Н. Научный вестник ВАГС: сб. науч. ст. Вып. 2. Социальноэкономические исследования, экономический анализ и проблемы управления / Т. Н. Сонина, С. С. Евдокимова. Волгоград : Изд-во ВАГС, 2002. С. 119-120.

50. Зенченко, C. В. Формирование и оценка регионального финансового потенциала устойчивого развития экономики территории: теория и методология : специальность 08.00.05 «Экономика и управление народным хозяйством» : автореферат диссертации на соискание ученой степени доктора экономических наук / Зенченко Светлана Вячеславовна. Ставрополь, 2009. 37 с.

51. Зенченко, С. В. Современная концепция формирования финансового потенциала региона / С. В. Зенченко // Региональные проблемы преобразования экономики. Махачкала : РАН ИСЭИ ДНЦ, 2007. № 3 (12). С. 103-108.

52. Тишутина, О. И. Методология определения финансового потенциала приграничного региона (на примере субъектов Дальневосточного федерального округа) / О. И. Тишутина // Финансы и кредит. № 1 (289). 2008. C. $23-28$.

53. Голодова, Ж. Г. Финансовый потенциал и экономический рост региона / Ж. Г. Голодова. Воронеж : Институт ИТОУР, 2010. 327 с.

54. Вербиненко, E. А. Финансовый потенциал регионов Арктической зоны РФ: оценка и принятие управленческих решений / Е. А. Вербиненко, Р. В. Бадылевич // Управление развитием крупномасштабных систем (MLSD’2017) : материалы Десятой междунар. конф. (2-4 октября 2017 г., Москва) : в 2 томах. Т. 2. Секции 5-13 / под общей редакцией С. Н. Васильева, А. Д. Цвиркуна ; Институт проблем управления им. В. А. Трапезникова ; Рос. акад. наук. Москва : ИПУ PAH, 2017. C. 166-169.

55. Голодова, Ж. Г. Финансовый потенциал региона: сущность и элементы управления / Ж. Г. Голодова // Вестник РУДН. Серия «Экономика». 2010. № 4. С. 13-21.

56. Вербиненко, E. A. Финансовые рычаги регулирования территориального развития / Е. А. Вербиненко, Р. В. Бадылевич // Север и рынок: формирование экономического порядка. 2016. № 3 (50). С. 28-39. 
57. Лукин, Ю. Ф. Российская Арктика в изменяющемся мире : монография / Ю. Ф. Лукин. Архангельск: ИПЦ САФУ, 2013. 464 с.

58. Канадское агентство экономического развития северных территорий : сайт. URL: http://www.cannor.gc.ca/eng/1381320711612/1381320727939 (дата обращения: 10.11.2018).

59. Департамент финансов Канады : сайт. URL: https://www.fin.gc.ca/fedprov/mtpeng.asp (дата обращения: 20.02.2017).

60. Alaska state budget and finances: [site]. URL: https://ballotpedia.org/ Alaska_state_budget_and_finances (accessed 10.11.2018).

61. Federal Spending Received Per Dollar of Taxes March 2006. URL: http://taxfoundation.org/sites/taxfoundation.org/files/docs/sr139.pdf (accessed 10.11.2018).

62. Alaska's Budget Challeng. URL: http://gov.alaska.gov/administration-focus/newsustainable-alaska-plan/ (accessed 10.11.2018).

63. Региональная политика стран ЕС / ответственный редактор А. В. Кузнецов ; Центр европейских исследований ИМЭМО РАН. Москва, 2009. 230 с.

64. Покровская, Н. В. Налоги в доходах местных бюджетов стран ОЭСР / Н. В. Покровская // Экономика. Налоги. Право. 2014. № 3. С. 33-37.

65. Показатели бюджетов коммун Лапландии в 2016 году. URL: http://www.lappi.fi/lapinliitto/c/document_library/get_file?folderId=139779\&na me=DLFE-29594.pdf (дата обращения: 10.11.2018).

66. Проект программы ПС Коларктик 2014-2020. URL: http://economy.gov.ru/ wps/wcm/connect/05f417d0-201b-4589-bcba-

f6a8e $495163 \mathrm{c} / \% \mathrm{D} 0 \% 9 \mathrm{~A} \% \mathrm{D} 0 \% \mathrm{BE} \% \mathrm{D} 0 \% \mathrm{BB} \% \mathrm{D} 0 \% \mathrm{~B} 0 \% \mathrm{D} 1 \% 80 \% \mathrm{D} 0 \% \mathrm{BA} \% \mathrm{D} 1$ $\% 82 \% \mathrm{D} 0 \% \mathrm{~B} 8 \% \mathrm{D} 0 \% \mathrm{BA}+\mathrm{JOP} . \mathrm{pdf}$ ?MOD=AJPERES\&CACHEID $=05 \mathrm{f} 417 \mathrm{~d} 0-$ 201b-4589-bcba-f6a8e495163c (дата обращения: 10.11.2018).

67. Фатеев, В. С. Местное самоуправление и региональная политика в Швеции / В. С. Фатеев // Белорусский экономический журнал. 2007. № 4 (41). С. 100-111.

68. Данные по разделу «Финансы»//Статистическое управление Швеции. URL: http://www.statistikdatabasen.scb.se/pxweb/en/ssd/START_OE_OE0115/Kom EkUtj/?rxid=e8d4bc01-3aec-4125-8b31-8e6035232aff (дата обращения: 10.11.2018).

69. Обзор экономики Норвегии // Торговое представительство РФ в Королевстве Норвегии : сайт. URL: http://www.rusnorge.com/?p=3357 (дата обращения: 10.11.2018).

70. Балтина, А. М. Межбюджетные отношения в регионе: модели организации и регулирования : монография / А. М. Балтина, В. А. Волохина. Оренбург : ОГУ, 2004. $197 \mathrm{c}$.

71. Inntektssystemet for kommunar og fylkeskommunar. Berekningsteknisk dokumentasjon til Prop. 1 S (2015-2016). 2016. URL: https://www.regjeringen.no/ contentassets/744de1ad6f0f4df09311c33edd01ae99/trykk_gront-hefte.pdf (accessed 10.11.2018).

72. Angell, E. Grimsrud the Rural and Regional Policy of Norway. Institutions, development features and current instruments / Elisabeth Angell, Yngve Flo, Gro Marit // Rokkan Centre. Stein Rokkan Centre for Social Studies. Report. 5-2016. URL: https://www.regjeringen.no/contentassets/744de1ad6f0f4df09311c33edd01ae99/t rykk_gront-hefte.pdf (accessed 10.11.2018). 
73. Ломоносов, М. В. Краткое описание разных путешествий по северным морям и показание возможного переходу Сибирским океаном в Восточную Индию. // Полное собрание сочинений / М. В. Ломоносов. Москва ; Ленинград, 1952. T. 6. C. 419-498.

74. Шиловский, М. В. Хозяйственное освоение Арктики в дореволюционной России / М. В. Шиловский // ЭКО. 2009. № 10 (424). С. 166-180.

75. Котошихин, Г. П. О России в царствовании Алексея Михайловича / Г. П. Котошихин. Санкт-Петербург, 1859. С. 93.

76. Тимошенко, А. И. Советский опыт мобилизационных решений в освоении Арктики и северного морского пути в 1930-1950-е гг. / А. И. Тимошенко // Арктика и Север. 2013. № 13.

77. Иванова, E. М. Проблемы инвестирования в хозяйственное развитие регионов российского Севера / Е. М. Иванова, А. Б. Себенцов // Вестник Российского университета дружбы народов. Серия: Экономика. 2007. № 2. C. $103-112$.

78. Карпов, В. П. Советские программы освоения Севера: от замысла к реализации / В. П. Карпов // Научный вестник Ямало-Ненецкого автономного округа. 2015. № 3 (88). С. $6-14$.

79. Об утверждении положения о льготах для лиц, работающих в отдаленных местностях союза ССР и вне крупных городских поселений : постановление от 12 августа 1930 года Центрального исполнительного Комитета СССР № 42 Совета Народных Комиссаров СССР № 204a. Текст : электронный // Справочная правовая система «Консультант Плюс» : [сайт]. URL: http://www.consultant.ru/cons/cgi/online.cgi?req $=$ doc\&base $=$ ESU\&n $=23513 \# 07$ 891499646910798 (дата обращения: 27.11.2017).

80. Об утверждении Положения о льготах для лиц, работающих на Крайнем Севере РСФСР : постановление ВЦИК, СНК РСФСР от 10.05.1932. Текст : электронный // Справочная правовая система «Консультант Плюс» : [сайт]. URL: http://www.consultant.ru/cons/cgi/online.cgi?req=doc\&base=ESU\&n=23869\#06 549510839055261 (дата обращения: 27.11.2017).

81. Об установлении территории, на которую распространяется действие постановления ВЦИК и СНК 10 мая 1932 г. о льготах для лиц, работающих на Крайнем Севере : постановление СНК РСФСР от 26.10.1932. Текст : электронный // Справочная правовая система «Консультант Плюс» : [сайт]. URL: http://www.consultant.ru/cons/cgi/online.cgi?req=doc\&base=ESU\&n= 24037\#041780918836319425 (дата обращения: 27.11.2017).

82. Дидык, В. В. Региональная инвестиционная политика / В. В. Дидык, Н. А. Серова // Пространственная экономика. 2005. № 4. С. 90-101.

83. Об основах государственного регулирования социально-экономического развития Севера Российской Федерации : федер. закон от 19.06.1996 № 78Ф3. Текст : электронный // Справочная правовая система «Консультант Плюс» : [сайт]. URL: http://www.consultant.ru/document/cons_doc_LAW_12023/ (дата обращения: 27.11.2017).

84. О критической ситуации в районах Крайнего Севера и приравненных к ним местностях : постановление Совета Федерации от 15.05.1997 № 163-СФ. Текст : электронный // Справочная правовая система «Гарант» : [сайт]. URL: https://base.garant.ru/3936768/ (дата обращения: 27.11.2017). 
85. О завершении реализации Федеральной целевой программы «Сокращение различий в социально-экономическом развитии регионов Российской Федерации (2002-2010 годы и до 2015 года)» : распоряжение Правительства РФ от 20.10.2006 № 1454-р. Текст : электронный // Справочная правовая система «Гарант» : [сайт]. URL: https://base.garant.ru/2160821/ (дата обращения: 27.11.2017).

86. О федеральной целевой программе «Экономическое и социальное развитие Дальнего Востока и Забайкалья на период до 2013 года : постановление Правительства РФ от 15.04.1996 № 480. Текст : электронный // Справочная правовая система «Гарант» : [сайт]. URL: http://base.garant.ru/1519225/ (дата обращения: 27.11.2017).

87. Федеральные целевые программы России / Минэкономразвития России. URL: http://fcp.economy.gov.ru/cgi-bin/cis/fcp.cgi/Fcp/ViewFcp/View/2016/136/ (дата обращения: 27.11.2017).

88. Об утверждении государственной программы «Социально-экономическое развитие Дальнего Востока и Байкальского региона» : распоряжение Правительства РФ от 29.03.2013 № 466-р. Текст : электронный // Справочная правовая система «Гарант» : [сайт]. URL: https://base.garant.ru/70351168/ (дата обращения: 27.11.2017).

89. Об Особой экономической зоне в Магаданской области : федер. закон от 31.05.1999 № 104-Ф3. Текст : электронный // Справочная правовая система «Гарант» : [сайт]. URL: https://base.garant.ru/12115795/ (дата обращения: 27.11.2017).

90. Дудкина, Н. С. Особая экономическая зона как стратегический ресурс инновационного развития северного региона (на примере Магаданской области) / Н. С. Дудкина // Проблемы современной экономики. 2013. № 1 (45). C. 134-137.

91. О внесении изменений в Федеральный закон «Об Особой экономической зоне в Магаданской области : федер. закон от 22.12.2014 № 423-Ф3. Текст : электронный // Справочная правовая система «Гарант» : [сайт]. URL: https://base.garant.ru/70826160/ (дата обращения: 27.11.2017).

92. О государственных гарантиях и компенсациях для лиц, работающих и проживающих в районах Крайнего Севера и приравненных к ним местностях : закон РФ от 19.02.1993 № 4520-1. Текст : электронный // Справочная правовая система «Гарант» : [сайт]. URL: https://base.garant.ru/10102007/ (дата обращения: 27.11.2017).

93. Вербиненко, E. А. Дифференциация регионов севера по уровню финансового потенциала / Е. А. Вербиненко, Р. В. Бадылевич // Интеллект. Инновации. Инвестиции. 2017. № 3. С. 7-13.

94. Север и Арктика в новой парадигме мирового развития: актуальные проблемы, тенденции, перспективы : научно-аналитический доклад / под научной редакцией В. С. Селина, Т. П. Скуфьиной, Е. П. Башмаковой, Е. Е. Торопушиной. Апатиты : КНЦ РАН, 2016. 420 с.

95. Кобылинская, $\Gamma$. В. Влияние структуры финансирования инвестиций на развитие регионов Севера / Г. В. Кобылинская // ЭКО. 2016. № 5 (503). C. 89-106. 
96. Ульченко, М. В. Анализ экономической безопасности европейской части Севера РФ / М. В. Ульченко // Север и рынок: формирование экономического порядка. 2014. № 6 (73). С. 59-64.

97. Финансовое регулирование развития регионов Крайнего Севера: институциональный аспект / коллектив авторов; под научной редакцией Г. В. Кобылинской. Апатиты : ФИЦ КНЦ РАН, 2018. 150 с.

98. Регионы России. Социально-экономические показатели. 2016: Р32 : стат. сб. / Росстат. Москва, 2016. 1326 с.

99. Регионы России. Основные характеристики субъектов Российской Р32 Федерации. 2016 : стат. сб. / Росстат. Москва, 2016. 671 с.

100. Рейтинг социально-экономического положения регионов - итоги 2015 года // Российское рейтинговое агентство «РИА Рейтинг» (подразделение медиагруппы «РИА Новости»). URL: http://riarating.ru/regions_rankings/ 20160615/630026438.html (дата обращения: 27.11.2017).

101. База данных «Оценка финансового потенциала северных и приравненных к северным регионов Российской Федерации за 2005, 2010, 2015 годы» : зарегистрирована Федеральной службой по интеллектуальной собственности 15 августа 2018 г., свидетельство о государственной регистрации базы данных № 2018621290.

102. Стратегия социально-экономического развития Дальнего Востока и Байкальского региона на период до 2025 года : утверждена распоряжением Правительства Российской Федерации от 28.12.2009 № 2094-р // Собрание законодательства Российской Федерации. 2010. 25 января, № 4. Ст. 421.

103. Программные возможности и повышенные обязательства // Восток России : Информационно-аналитическое агентство. URL: https://www.eastrussia.ru/ material/programmnye-vozmozhnosti/ (дата обращения: 20.11.2017).

104.Бадылевич, P. В. Оценка финансового потенциала Мурманской области и направления повышения эффективности его использования / Р. В. Бадылевич, Е. А. Вербиненко // Север и рынок: формирование экономического порядка. 2013. № 5 (36). С. 12-17.

105. Финансовое обеспечение развития северных регионов / Р. В. Бадылевич [и др.] ; под научной редакцией Г. В. Кобылинской. Апатиты : КНЦ РАН, 2016. 193 c.

106. О распределении дотаций на выравнивание бюджетной обеспеченности субъектов Российской Федерации : постановление Правительства РФ от 22.11.2004 № 670 // Собрание законодательства РФ. 2004. 29 ноября, № 48. Ст. 4797

107. Бюджет для граждан к Федеральному закону о федеральном бюджете на 2019 год и на плановый период 2020 и 2021 годов / Минфин России : сайт. URL: https://www.minfin.ru/ru/document/?id_4=126379 (дата обращения: 20.09.2019).

108. Показатели уровня долговой нагрузки субъектов РФ - итоги 2018 года // Рейтинговое агентство «РИА Рейтинг». URL: http://vid1.rian.ru/ig/ratings/ gosdolg_2019.pdf (дата обращения 26.06.2019).

109. Об утверждении государственной программы Российской Федерации «Социально-экономическое развитие Арктической зоны Российской Федерации» : постановление Правительства РФ от 21.04.2014 № 366 // Собрание законодательства РФ. 2014. 5 мая, № 18 (часть IV). Ст. 2207. 
110. Об утверждении государственной программы Российской Федерации «Социально-экономическое развитие Дальнего Востока и Байкальского региона» : постановление Правительства РФ от 15.04.2014 № 308 // Собрание законодательства РФ. 2014. 5 мая, № 18 (часть I). Ст. 2154.

111.Барашева, Т. И. Бюджетно-налоговое регулирование в регионах Севера и Арктики: возможности и ограничения / Т. И. Барашева // Труды Ферсмановской научной сессии ГИ КНЦ РАН. 2017. № 14. С. 498-500.

112. Значения показателя «Объем налоговых и неналоговых доходов консолидированного бюджета субъекта Российской Федерации» : данные системы ЕМИСС. URL: https://www.fedstat.ru/indicator/44609 (дата обращения 10.07.2019).

113. Кобылинская, Г. В. Внутренние резервы развития Арктического региона: финансовый аспект / Г. В. Кобылинская // Север и рынок: формирование экономического порядка. 2015. № 2 (45). С. 49-59.

114. Государственно-частное партнерство в России 2016-2017: текущее состояние и тренды, рейтинг регионов : исследование / Ассоциация «Центр развития ГЧП». Москва, 2016. $32 \mathrm{c.}$

115. Сбитнева, A. E. Роль прямых иностранных инвестиций в экономике России / А. Е. Сбитнева, Н. П. Шалыгина, М. В. Селюков // Фундаментальные исследования. 2017. № 9-1. C. 237-242.

116. ЯНАО предлагает населению облигации с северной надбавкой // Коммерсант.ru. URL: https://www.kommersant.ru/doc/3441028 (дата обращения: 10.07.2019). 
ИНСТИТУТ ЭКОНОМИЧЕСКИХ ПРОБЛЕМ ИМ. Г.П. ЛУЗИНА ОБОСОБЛЕННОЕ ПОДРАЗДЕЛЕНИЕ ФГБУН

ФЕДЕРАЛЬНОГО ИССЛЕДОВАТЕЛЬСКОГО ЦЕНТРА

«КОЛЬСКИЙ НАУЧНЫЙ ЦЕНТР РОССИЙСКОЙ АКАДЕМИИ НАУК»

РоССИЯ, 184209, Мурманская область, г.Апатиты, ул.Ферсмана, 24а
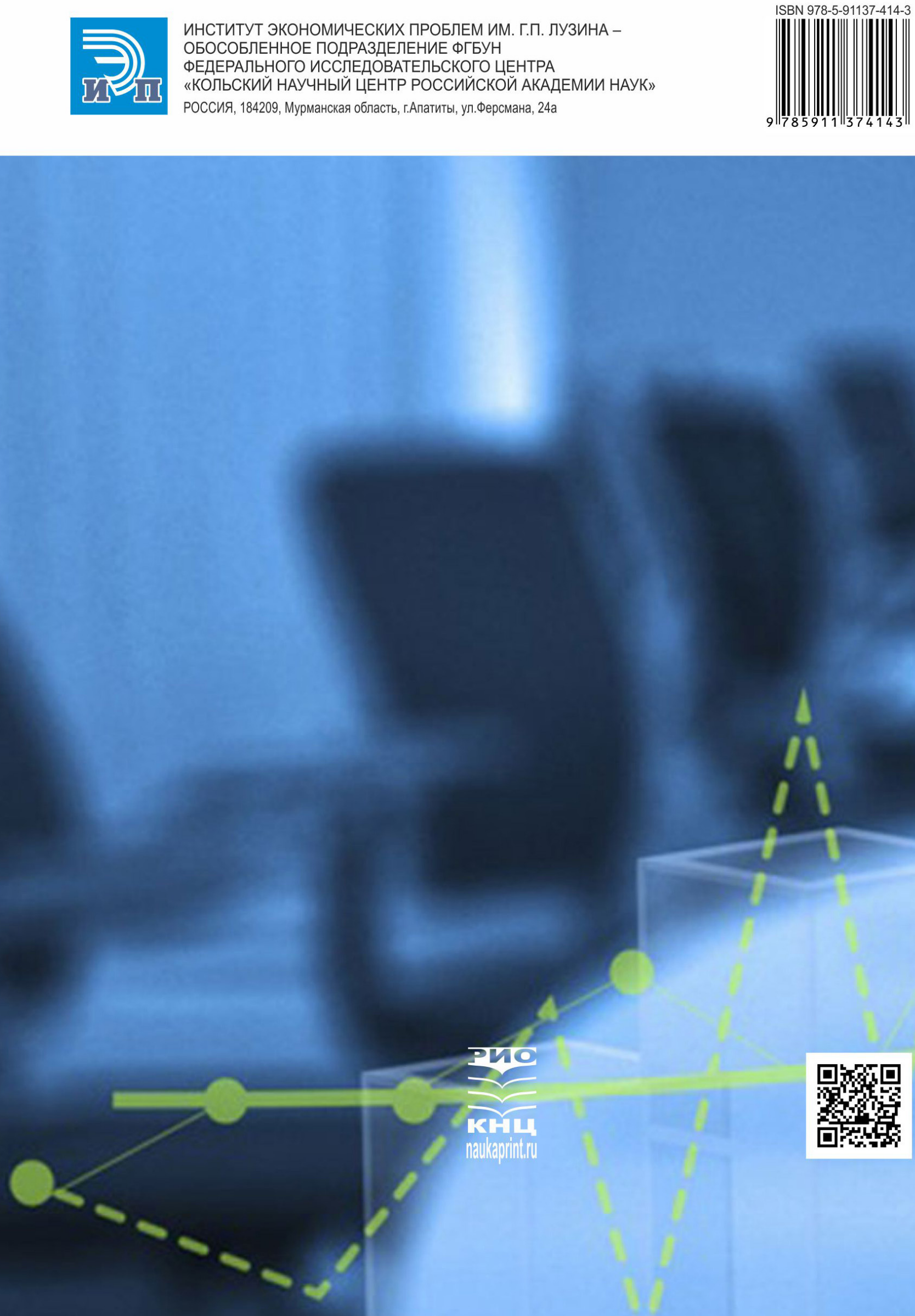

\section{口还回 \\ sx \\ 的}

